PNNL-15544

\title{
Hanford Tank 241-C-106: Impact of Cement Reactions on Release of Contaminants from Residual Waste
}

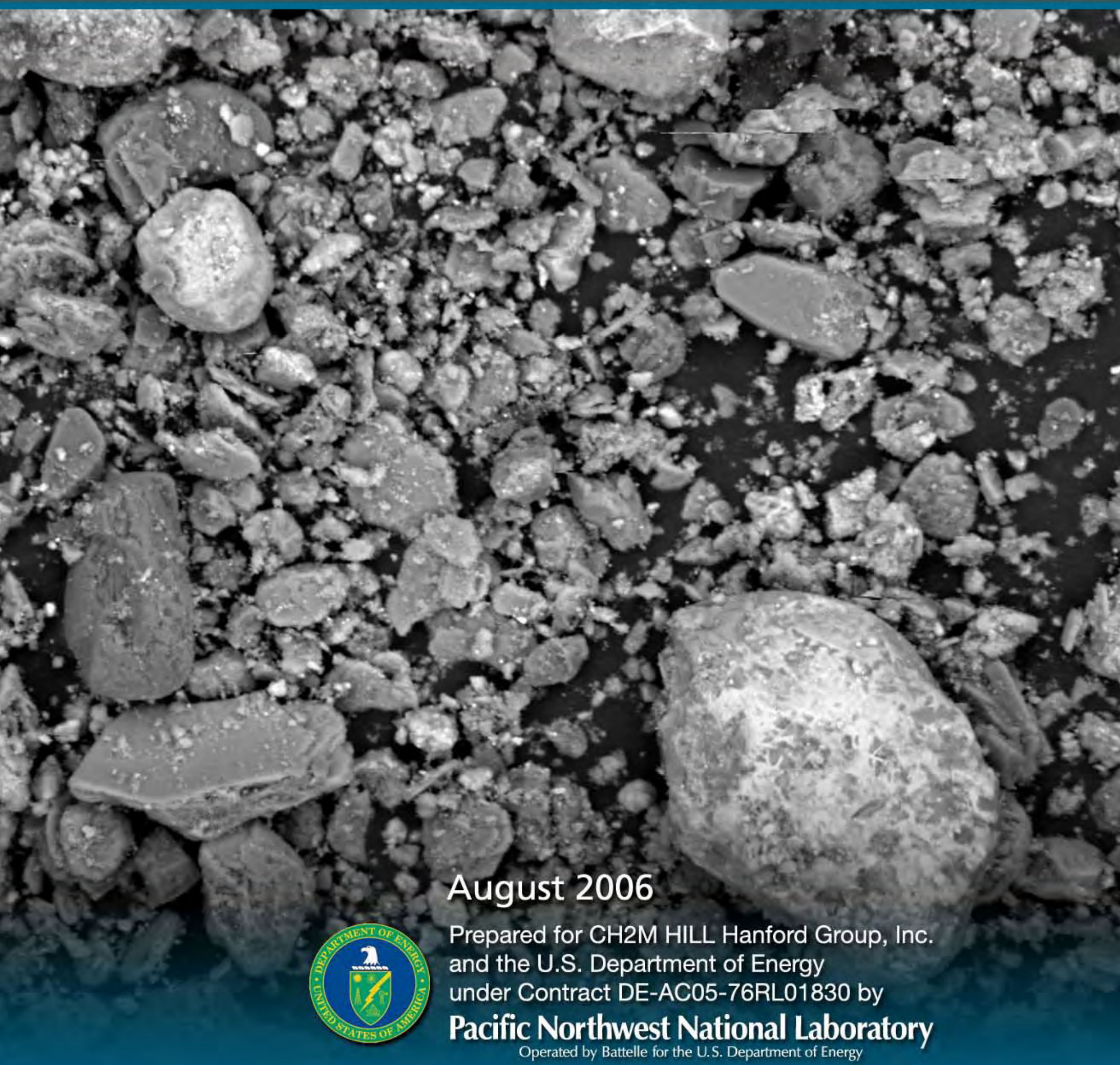




\title{
DISCLAIMER
}

This report was prepared as an account of work sponsored by an agency of the United States Government. Neither the United States Government nor any agency thereof, nor Battelle Memorial Institute, nor any of their employees, makes any warranty, express or implied, or assumes any legal liability or responsibility for the accuracy, completeness, or usefulness of any information, apparatus, product, or process disclosed, or represents that its use would not infringe privately owned rights. Reference herein to any specific commercial product, process, or service by trade name, trademark, manufacturer, or otherwise does not necessarily constitute or imply its endorsement, recommendation, or favoring by the United States Government or any agency thereof, or Battelle Memorial Institute. The views and opinions of authors expressed herein do not necessarily state or reflect those of the United States Government or any agency thereof.

\author{
PACIFIC NORTHWEST NATIONAL LABORATORY \\ operated by \\ BATTELLE \\ for the \\ UNITED STATES DEPARTMENT OF ENERGY \\ under Contract DE-AC05-76RL01830 \\ Printed in the United States of America \\ Available to DOE and DOE contractors from the \\ Office of Scientific and Technical Information, \\ P.O. Box 62, Oak Ridge, TN 37831-0062; \\ ph: (865) 576-8401 \\ fax: (865) 576-5728 \\ email: reports@adonis.osti.gov
}

\begin{abstract}
Available to the public from the National Technical Information Service, U.S. Department of Commerce, 5285 Port Royal Rd., Springfield, VA 22161 ph: (800) 553-6847

fax: (703) 605-6900

email: orders@ntis.fedworld.gov

online ordering: http://www.ntis.gov/ordering.htm
\end{abstract}

The cover image shows an SEM micrograph of particles present in tank C-106 residual waste after leaching of the material with a $\mathrm{Ca}(\mathrm{OH})_{2}$ solution. EDS analysis indicates that the major elements in most of these phases are $\mathrm{Ca}, \mathrm{Al}, \mathrm{Mn}, \mathrm{O}$, and $\mathrm{C}$.

Cover design is by S.B. Neely, Pacific Northwest National Laboratory, Richland, Washington.

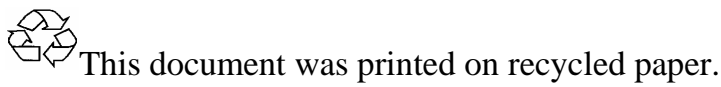




\title{
Hanford Tank 241-C-106: Impact of Cement Reactions on Release of Contaminants from Residual Waste
}

\author{
W. J. Deutsch \\ K. J. Cantrell \\ K. M. Krupka \\ C. F. Brown \\ M. J. Lindberg \\ H. T. Schaef
}

August 2006

Prepared for

CH2M HILL Hanford Group, Inc. and

the U.S. Department of Energy

under Contract DE-AC05-76RL01830

Pacific Northwest National Laboratory

Richland, Washington 99352 


\section{Summary}

The CH2M HILL Hanford Group, Inc. (CH2M HILL) is producing risk/performance assessments to support the closure of single-shell tanks at the U.S. Department of Energy's Hanford Site. As part of this effort, staff at Pacific Northwest National Laboratory were asked to develop release models for contaminants of concern that are present in residual sludge remaining in tank 241-C-106 (C-106) after final retrieval of waste from the tank. Initial work to produce release models was conducted on residual tank sludge using pure water as the leaching agent. The results were reported in Deutsch et al. (2005a). One of the options under consideration for closure after waste retrieval is to fill the tanks with a cementitious grout to minimize infiltration and maintain the physical integrity of the tanks. The presence of a cementitious grout above the residual waste may impact contaminant leaching. This report describes testing of the residual waste with a leaching solution that simulates the composition of water passing through a grout and contacting the residual waste at the bottom of the tank.

The primary contaminants of concern in the sludge are ${ }^{99} \mathrm{Tc},{ }^{238} \mathrm{U},{ }^{129} \mathrm{I}$, and $\mathrm{Cr}$ because of their potential mobility in the environment and the long half-lives of the radionuclides. A key result from this work is that high percentages ( $\geq 90 \%$ ) of these primary contaminants are not readily leachable from the residual waste in contact with pure water or with the cementitious grout simulants. This minimizes their future release to the environment, and is similar to results found in related studies of sludges from tanks AY-102, C-203, and C-204.

The simulants selected to represent the solutions that will contact the residual sludge consisted of a $0.01 \mathrm{M} \mathrm{Ca}(\mathrm{OH})_{2}$ solution and a solution in equilibrium with calcite $\left(\mathrm{CaCO}_{3}\right)$. The $\mathrm{Ca}(\mathrm{OH})_{2}$ solution represented fresh grout and the $\mathrm{CaCO}_{3}$ solution represented aged grout in which calcite had precipitated on the surfaces of the grout and this mineral controlled the major ion composition of the solution in contract with the grout. Laboratory tests were conducted to evaluate the leachability of sludge constituents and to characterize the sludge solid phases before and after leaching. The leaching tests consisted of single-contact batch tests and six stages of sequential batch leaching tests. Solid phase analyses consisted of x-ray diffraction (XRD) and scanning electron microscopy/energy dispersive spectrometry (SEM/EDS) analyses to identify reactive phases and estimate their composition.

The results of the leaching tests with the grout simulants were compared to the results for the pure water tests. ${ }^{99}$ Tc was approximately 4 times more leachable in the $\mathrm{Ca}(\mathrm{OH})_{2}$ leachant than in water, but the increase in leachability was still only $\sim 10 \%$ of the total ${ }^{99}$ Tc in the sludge. The leachability of ${ }^{238} \mathrm{U}$ was approximately equal for the cementitious conditions and the pure water conditions. In each case, only a few percent of the total ${ }^{238} \mathrm{U}$ in the sludge was leachable. The other primary contaminants of interest $\left({ }^{129} \mathrm{I}\right.$ and $\mathrm{Cr}$ ) were not detected in the leachates and, thus, also appear to be in a stable form in the residual sludge. Other components of the sludge that were less leachable in the cementitious simulants

were $\mathrm{Fe}, \mathrm{Mn}$, and oxalate. Components that were more leachable were $\mathrm{Al},{ }^{90} \mathrm{Sr}$, and ${ }^{137} \mathrm{Cs}$. $\mathrm{Al}$ is probably more mobile because it forms a strong solution complex $\left[\mathrm{Al}(\mathrm{OH})_{4}{ }^{-}\right]$under the high $\mathrm{pH}(12)$ conditions of the simulants and ${ }^{90} \mathrm{Sr}$ and ${ }^{137} \mathrm{Cs}$ are more mobile because the $\mathrm{Ca}$ in the simulant competes with these cations for ion exchange sites on the sludge.

Interactions of the cement simulants with the residual sludge produced a change in some of the mineralogy of the sludge. It appears that the $\mathrm{Mn}$ minerals rhodochrosite $\left(\mathrm{MnCO}_{3}\right)$ and lindbergite 
$\left(\mathrm{MnC}_{2} \mathrm{O}_{4} \cdot 2 \mathrm{H}_{2} \mathrm{O}\right)$ were converted to calcite $\left(\mathrm{CaCO}_{3}\right)$, whewellite $\left(\mathrm{CaC}_{2} \mathrm{O}_{4} \cdot \mathrm{H}_{2} \mathrm{O}\right)$ and a poorly defined amorphous Mn oxyhydroxide phase. Dawsonite $\left(\mathrm{NaAl}(\mathrm{OH})_{2} \mathrm{CO}_{3}\right)$ was converted to calcite and released $\mathrm{Na}$ and $\mathrm{Al}$ to solution. These phase transformations account for some of the changes in leachability between the cement simulant and pure water systems.

Because a correlation could not be established between the contaminants of interest and the identified solid phases, mechanistic release models for these contaminants could not be developed. In their place, empirical release models were developed based on initial sludge concentrations and dissolved contaminant concentrations in the leaching solutions. These empirical models provide the source terms for the release of contaminants from residual sludge in tank C-106 filled with cementitious grout. 


\section{Acknowledgments}

The authors wish to acknowledge M. Connelly, F.J. Anderson, and F.M. Mann at CH2M HILL Hanford Group, Inc. (Richland, Washington) for providing project funding and technical guidance. We greatly appreciate the technical reviews provided by T.E. Jones (CH2M HILL), M.I. Wood (Fluor Hanford, Inc., Richland, Washington), R.J. Serne, and W. Um (both of PNNL). The authors would also like to thank B.W. Arey (PNNL) for conducting the SEM/EDS analyses of the sludge samples and S.R. Baum, K.M. Geiszler, I.V. Kutnyakov, and R.D. Orr (all of PNNL) for completing the chemical and radiochemical analyses of the solution samples from our studies. We are also particularly grateful to L.F. Morasch (PNNL) for completing the editorial review and K.R. Neiderhiser (PNNL) for final formatting of this technical report. 


\section{Acronyms and Abbreviations}

ASTM

BSE

C-106

CH2M HILL

$\mathrm{CSH}$

DDI

DOE

EDS

EPA

EQL

GEA

HASQARD

$\mathrm{HF}$

ICP-MS

ICP-OES

ICDD

JCPDS

LEPS

LSC

NIST

PDFTM

PNNL

QA

RPL

SE

SEM

SRM

TEM

XRD
American Society for Testing and Materials

backscattered electron

241-C-106 tank

CH2M HILL Hanford Group, Inc.

calcium silicate hydrogel

double deionized (water)

U.S. Department of Energy

energy dispersive spectrometry

U.S. Environmental Protection Agency

estimated quantitation limit

gamma energy analysis

Hanford Analytical Services Quality Assurance Requirements Document hydrofluoric

inductively coupled plasma-mass spectroscopy (spectrometer)

inductively coupled plasma-optical emission spectroscopy (same as ICP-AES)

International Center for Diffraction Data, Newtown Square, Pennsylvania

Joint Committee on Powder Diffraction Standards

Low Energy Photon System

liquid scintillation counting

National Institute of Standards and Technology

powder diffraction file

Pacific Northwest National Laboratory

quality assurance

Radiochemical Processing Laboratory

secondary electron

scanning electron microscopy (or microscope)

Standard Reference Material

transmission electron microscopy (or microscope)

x-ray powder diffractometry analysis (commonly called x-ray diffraction) 


\section{Units of Measure}

$\begin{array}{ll}\AA & \text { angstrom } \\ \theta & \text { angle of incidence (Bragg angle) } \\ \Delta_{\mathrm{f}} \mathrm{G}_{298}{ }^{\circ} & \text { Gibbs energy of formation from the elements in their reference states at } 298.15 \mathrm{~K} \\ { }^{\circ} \mathrm{C} & \text { temperature in degrees Celsius }\left[\mathrm{T}\left({ }^{\circ} \mathrm{C}\right)=\mathrm{T}(\mathrm{K})-273.15\right) \\ \mathrm{Ci} & \text { curie } \\ \mathrm{cps} & \text { counts per second } \\ \mathrm{ft} & \text { foot } \\ \mathrm{g} & \text { gram } \\ \mathrm{gal} & \text { gallon } \\ \mathrm{in} . & \text { inch } \\ \mathrm{K} & \text { temperature in degrees (without degree symbol) Kelvin }\left[\mathrm{T}(\mathrm{K})=\mathrm{T}\left({ }^{\circ} \mathrm{C}\right)+273.15\right] \\ \mathrm{K}_{298}{ }^{\circ} & \text { equilibrium constant at } 298.15 \mathrm{~K} \\ \mathrm{kcal} & \text { kilocalorie, one calorie equals } 4.1840 \text { joules } \\ \mathrm{keV} & \text { kilo-electron volt } \\ \mathrm{kJ} & \text { kilojoule, one joule equals } 4.1840 \text { thermochemical calories } \\ \mathrm{L} & \text { liter } \\ \mu & \left.\text { micro (prefix, } 10^{-6}\right) \\ \mu \mathrm{Ci} & \text { microcurie } \\ \mu \mathrm{g} & \text { microgram } \\ \mu \mathrm{m} & \text { micrometer } \\ \mathrm{M} & \text { molarity, mol/L } \\ \mathrm{mA} & \text { milliAmpere } \\ \mathrm{mg} & \text { milligram } \\ \mathrm{mL} & \text { milliliter } \\ \mathrm{mM} & \text { millimolar } \\ \mathrm{rpm} & \text { revolution per minute } \\ \lambda & \text { wavelength } \\ \mathrm{wt} \% & \text { weight percent } \\ & \end{array}$




\section{Contents}

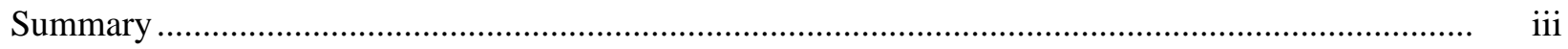

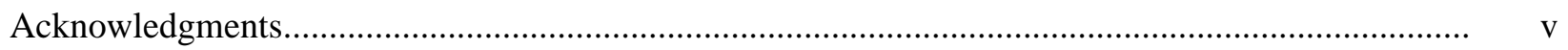

Acronyms and Abbreviations ...................................................................................................... vii

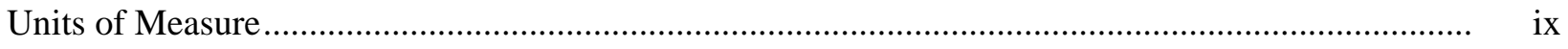

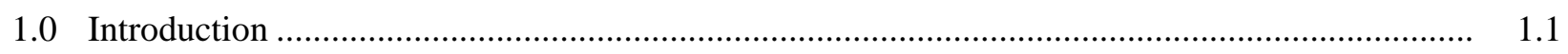

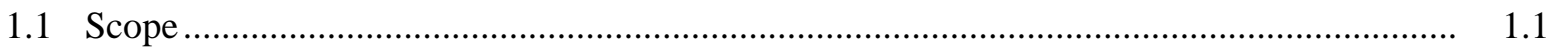

1.2 C-106 Tank Description .......................................................................................... 1.2

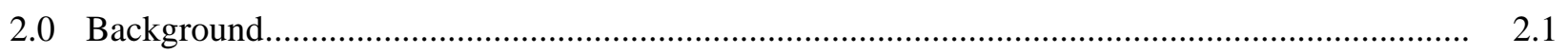

3.0 Materials and Laboratory Test Methods ........................................................................... 3.1

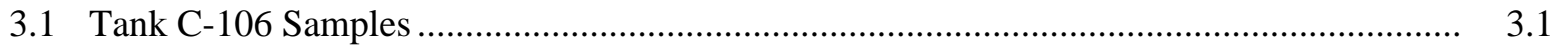

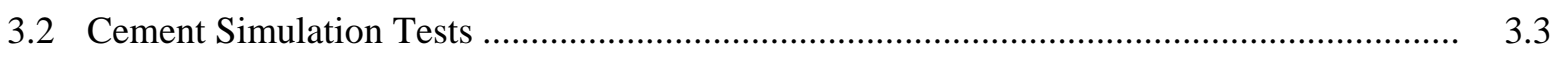

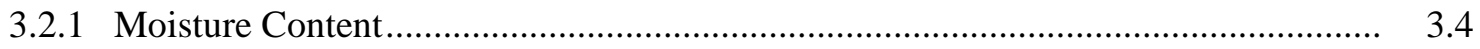

3.2.2 Single Contact Batch Leaching Test …................................................................ 3.4

3.2.3 Sequential Contact Leaching Test ........................................................................ 3.5

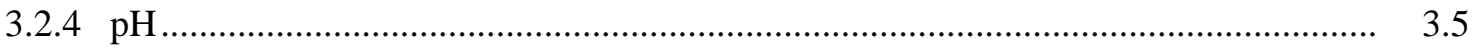

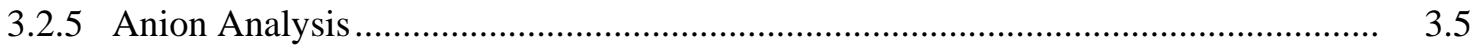

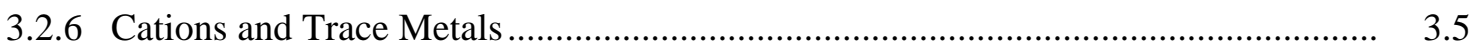

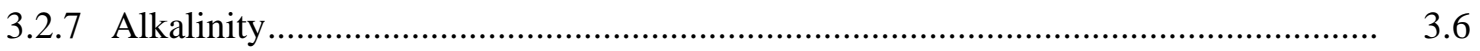

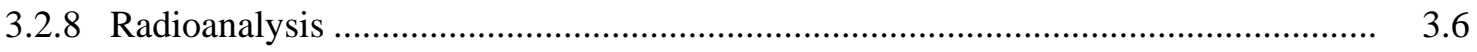

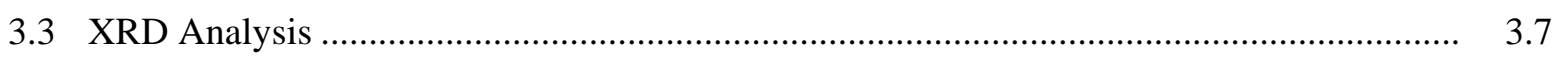

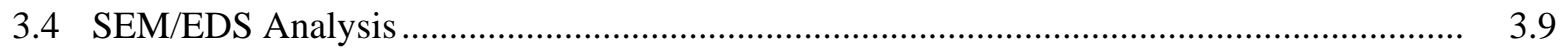

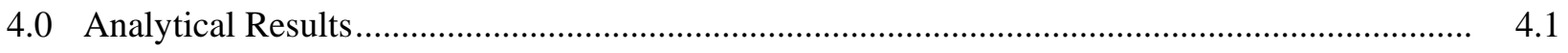

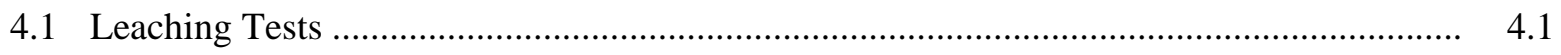

4.1.1 Single Contact Batch Leaching .............................................................................. 4.1

4.1.2 Sequential Contact Leaching Test ............................................................................ 4.3

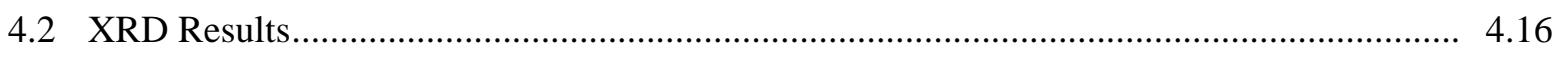

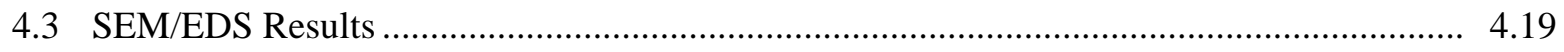

5.0 Contaminant Release Model.................................................................................................. 5.1

5.1 Modification of the Conceptual Model of Chemical Transformations of Tank C-106 Sludge Resulting from a Cementitious Tank Filler ......................................................... 5.2

5.2 Release Models for Technetium, Uranium, Iodine, and Chromium in a Tank Filled with Cementitious Grout ............................................................................................. 5.3

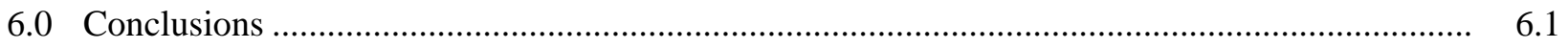

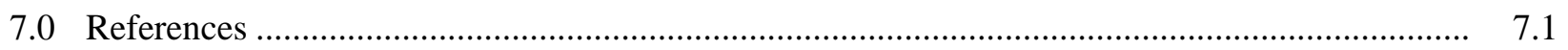

Appendix A - X-Ray Diffraction Patterns for $\mathrm{Ca}(\mathrm{OH})_{2}$ - and $\mathrm{Ca}(\mathrm{OH})_{2} / \mathrm{CaCO}_{3}$-Leached Tank C-106 Residual Waste 
Appendix B - SEM Micrographs and EDS Results for 1-Month $\mathrm{Ca}(\mathrm{OH})_{2}$-Leached

Tank C-106 Residual Waste

Appendix C - SEM Micrographs and EDS Results for Stage 6 Sequential $\mathrm{Ca}(\mathrm{OH})_{2}{ }^{-}$ Leached Tank C-106 Residual Waste

Appendix D - SEM Micrographs and EDS Results for 1-Month $\mathrm{Ca}(\mathrm{OH})_{2} / \mathrm{CaCO}_{3}$ Leached Tank C-106 Residual Waste.

Appendix E - SEM Micrographs and EDS Results for Stage 6 Sequential $\mathrm{Ca}(\mathrm{OH})_{2} /$ $\mathrm{CaCO}_{3}$-Leached Tank C-106 Residual Waste

Appendix F - Solution Concentrations of Tank C-106 Solution Contact Tests with Residual Sludge

\section{Figures}

1.1 Location Map of Hanford Waste Management Area C Containing Tank C-106

1.2 Tank C-106 Configuration

1.3 Tank C-106 Sludge at 222-S Laboratory

3.1 Tank C-106 Field Primary Solid Composite Sludge Sample 404

3.2 Tank C-106 Field Duplicate Solid Composite Sludge Sample 405

3.3 Leach Test Flowpath

3.4 Exploded Schematic View of the XRD Sample Holder..

3.5 XRD Pattern for Collodion Film Measured in the Absence of any Sludge Material

4.1 Background-Subtracted XRD Patterns for 1-Month and Stage 6 Sequential $\mathrm{Ca}(\mathrm{OH})_{2^{-}}$ Leached and for Unleached C-106 Residual Waste Compared to the Matching PDF Database Patterns ....

4.2 Background-Subtracted XRD Patterns for 1-Month and Stage 6 Sequential $\mathrm{CaCO}_{3}$ Leached and for Unleached C-106 Residual Waste Compared to the Matching PDF Database Patterns

4.3 Comparison of Background-Subtracted XRD Patterns for 1-Month $\mathrm{Ca}(\mathrm{OH})_{2}$ - and 1-Month $\mathrm{CaCO}_{3}$ - Leached Samples of Unleached C-106 Residual Waste

4.4 Low Magnification SEM Micrographs of Particles Present in 1-Month and Stage 6 Sequential $\mathrm{Ca}(\mathrm{OH})_{2}$-Leached and 1-Month and Stage 6 Sequential $\mathrm{CaCO}_{3}$-Leached C-106 Residual Waste

4.5 Low Magnification SEM Micrographs of Particles Present in the Unleached, 1-Month Water-Leached, and HF Stage 1 Extract of Oxalic Acid-Treated Residual Waste from Tank C-106.

4.6 SEM Micrograph of Typical Particle Aggregates Present in 1-Month $\mathrm{Ca}(\mathrm{OH})_{2}$-Leached C-106 Residual Waste and Spectra for Areas Analyzed by EDS

4.7 SEM Micrograph of Typical Particles Present in Stage 6 Sequential $\mathrm{Ca}(\mathrm{OH})_{2}$-Leached C-106 Residual Waste and Spectra for Areas Analyzed by EDS

4.8 SEM Micrograph of Typical Particles Present in Stage 6 Sequential $\mathrm{Ca}(\mathrm{OH})_{2}$-Leached C-106 Residual Waste and Spectra for Areas Analyzed by EDS 
4.9 SEM Micrograph of Typical Particles Present in 1-Month $\mathrm{CaCO}_{3}$-Leached C-106

Residual Waste and Spectra for Areas Analyzed by EDS

4.10 SEM Micrograph of Typical Particles Present in Stage 6 Sequential $\mathrm{CaCO}_{3}$-Leached

C-106 Residual Waste and Spectra for Areas Analyzed by EDS

4.11 SEM Micrograph of Typical Particles Present in Stage 6 Sequential $\mathrm{CaCO}_{3}$-Leached C-106 Residual Waste and Spectra for Areas Analyzed by EDS

4.12 Backscatter-Electron SEM Image and Colorized Element Maps for a Particle Aggregate from the 1-Month $\mathrm{Ca}(\mathrm{OH})_{2}$-Leached C-106 Residual Waste

4.13 Backscatter-Electron SEM Micrograph and Element Distribution Maps for Particles in 1-Month $\mathrm{Ca}(\mathrm{OH})_{2}$-Leached C-106 Residual Waste.

4.14 Backscatter-Electron SEM Image and Colorized Element Maps for a Particle Aggregate from the Stage 6 Sequential $\mathrm{Ca}(\mathrm{OH})_{2}$-Leached C-106 Residual Waste

4.15 Backscatter-Electron SEM Micrograph and Element Distribution Maps for Particles in Stage 6 Sequential $\mathrm{Ca}(\mathrm{OH})_{2}$-Leached C-106 Residual Waste

4.16 Backscatter-Electron SEM Micrograph and Element Distribution Maps for Particles in Stage 6 Sequential $\mathrm{Ca}(\mathrm{OH})_{2}$-Leached C-106 Residual Waste

4.17 Backscatter-Electron SEM Image and Colorized Element Maps for a Particle Aggregate from the 1-Month $\mathrm{CaCO}_{3}$-Leached C-106 Residual Waste

4.18 Backscatter-Electron SEM Micrograph and Element Distribution Maps for Particles in 1-Month $\mathrm{CaCO}_{3}$-Leached C-106 Residual Waste

4.19 Backscatter-Electron SEM Image and a Colorized Element Map for a Particle Aggregate from the Stage 6 Sequential $\mathrm{CaCO}_{3}$-Leached C-106 Residual Waste.

4.20 Backscatter-Electron SEM Micrograph and Element Distribution Maps for Particles in Stage 6 Sequential $\mathrm{CaCO}_{3}$-Leached C-106 Residual Waste .....

5.1 Source Release Model Development for Long-Term Risk/Performance Assessments

5.2 Chemical Transformations of Tank C-106 Residual Sludge Resulting from Contact with Cementitious Grout Leachate.

\section{Tables}

2.1 Sample 403 - Tank C-106 Liquid Sample Composition.

3.1 Tank C-106 Samples Provided by 222-S Laboratory to PNNL

4.1 Water Extract pH and Alkalinity Values Corrected to Grams of Dry Sludge.

$4.2{ }^{99} \mathrm{Tc},{ }^{238} \mathrm{U}$, and ${ }^{129}$ I Concentrations Leached During Single-Contact Batch Tests

4.3 Leachable Percentages of ${ }^{99} \mathrm{Tc},{ }^{238} \mathrm{U}$, and ${ }^{129} \mathrm{I}$ in C-106 Sludge Samples Compared with Fusion Results

4.4 Leachable Metal Concentrations in Single Contact Batch Test

4.5 Average Anion Concentrations Leached During Single Contact Batch Test.....

4.6 $\quad{ }^{137}$ Cs Leached During Single Contact Batch Test 
4.7 ${ }^{90} \mathrm{Sr}$ and Actinides Leached During Single Contact Batch Test

4.8 Contact Times, pH Range, and Alkalinities for Sequential Contact Leaching Test on Tank C-106 Sludge Samples

$4.9{ }^{99}$ Tc and ${ }^{238} \mathrm{U}$ Concentrations Leached During Sequential Contact Test......

4.10 Water-Leachable Percentages of ${ }^{99} \mathrm{Tc},{ }^{238} \mathrm{U}$, and ${ }^{129} \mathrm{I}$ in Tank C-106 Sludge Sequential Contact Leaching Test Relative to Fusion Results.

4.11 Metals Concentrations Leached During Sequential Contact Tests

4.12 Anion Concentrations Leached During Sequential Contact Tests

$4.13{ }^{137}$ Cs Concentrations Leached During Sequential Contact Tests ....

$4.14{ }^{90} \mathrm{Sr}$ and Actinide Concentrations Leached During Sequential Contact Tests.....

4.15 Comparison of XRD and SEM/EDS Results for the Unleached Samples of Residual Waste from Tank C-106 to the Results for the $\mathrm{Ca}(\mathrm{OH})_{2}$ - and $\mathrm{CaCO}_{3}$-Leached Samples

5.1 Summary of Contaminant Release Model Data for Tank C-106, Fresh Cement Scenario

5.2 Summary of Contaminant Release Model Data for Tank C-106, Aged Cement Scenario 5.4

5.3 Summary of Contaminant Release Model Data for C-106, Fresh Water Scenario. 


\subsection{Introduction}

One of the closure methods under consideration for the Hanford tanks after waste retrieval is to fill them with a cement grout to maintain the structural integrity of the tank. The grout would be poured on top of any residual waste left in the tank, and little mixing between the materials is expected. Recharge water entering the tank in the future would pass through the cementitious material before contacting residual waste at the bottom of the tank. This water would take on the chemical characteristics of the cement. Leaching studies of residual tank waste are being conducted to develop long-term contaminant release rates for use in performance assessments. In the past, the leaching studies were conducted with deionized water. Now that filling the tanks with cementitious material is being considered as a possible component of the closure process, leaching studies with simulants of fresh and aged cement will also be conducted as part of the closure assessment process.

This report describes the development of release models for contaminants of concern that may be present in residual sludge in Hanford tank 241-C-106 (C-106) after closure. These release models are necessary components of the risk assessments being conducted as part of the closure process. From the perspective of long-term risk to the environment, the primary contaminants of concern are ${ }^{99} \mathrm{Tc},{ }^{238} \mathrm{U},{ }^{129} \mathrm{I}$, and $\mathrm{Cr}$ because of their mobility in the environment and long half-lives for the radionuclides. Sludge samples and a sample of the liquid from tank C-106 were collected after final sludge retrieval to characterize the geochemistry of the reactive phases and to quantify the release of primary contaminants into water that may contact residual sludge after tank closure.

The remainder of this section describes the scope of work for laboratory testing and release model development as well as background information on this tank. The samples and laboratory testing procedures for this project are described in Section 2 of this report, and the results are provided in Section 3. Release models are discussed in Section 4 and general conclusions in Section 5. Cited references are listed in Section 6, and supporting material is included in the appendices.

\subsection{Scope}

Initial (Tier 1) laboratory tests were conducted to characterize the sludge and identify water-leachable constituents. The Tier 1 tests consisted primarily of fusion and acid digestions (which measured element concentrations in the solid) and water leaching of contaminants from the sludge to evaluate their mobility in infiltrating water. Based on the results of Tier 1 tests, additional analyses were performed to augment the characterization of the material and determine the controlling mechanism(s) for release of contaminants. Tier 2 tests consisted of analyses of the solids using x-ray diffraction (XRD) and scanning electron microscopy/energy dispersive spectrometry (SEM/EDS) to identify reactive phases, and selective extractions in order to quantify the release of contaminants from particular solid phases. The results of these initial tests were documented in Deutsch et al. (2005a). Subsequent Tier 1 and 2 tests on tank C-106 residual waste were conducted using cement simulants to leach the waste. The results of these tests are the subject of this report.

The laboratory results of residual sludge and liquid testing were used to develop source term models that describe the release of contaminants as infiltrating water contacts the solids in the future. These models simulate the geochemical system in the tank sludge and take into account interactions between the 
solution phase and the contaminant-containing solids. The release models are simplifications of the complex geochemical interactions occurring between the phases; however, they adequately represent the release of the key contaminants ${ }^{99} \mathrm{Tc},{ }^{238} \mathrm{U},{ }^{129} \mathrm{I}$, and $\mathrm{Cr}$ from the sludge as measured in laboratory tests.

\subsection{C-106 Tank Description}

Tank C-106 is a single-shell underground waste tank located in the C Tank Farm in the 200 East Area of the Hanford Site (Figure 1.1). It was constructed between 1943 and 1944 and put into service during September 1947. This tank is $22.8 \mathrm{~m}$ (75 ft) in diameter and has a capacity of 2,006,268 L (530,000 gal) when filled to a depth of $5.2 \mathrm{~m}(17 \mathrm{ft})$. Figure 1.2 is a diagram showing the configuration of tank C-106.

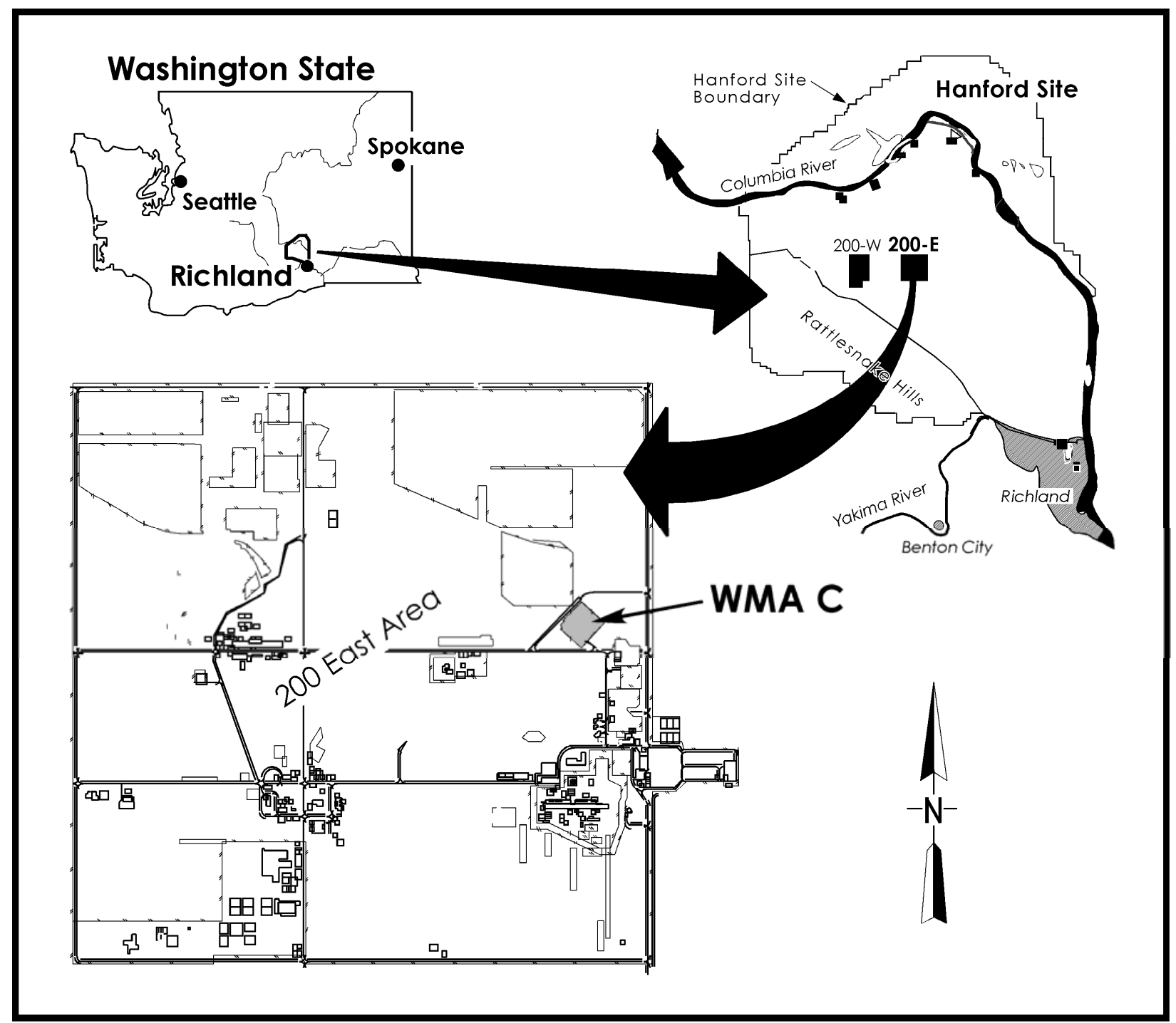

2005/DCL/C/009 (11/17)

Figure 1.1. Location Map of Hanford Waste Management Area C Containing Tank C-106 

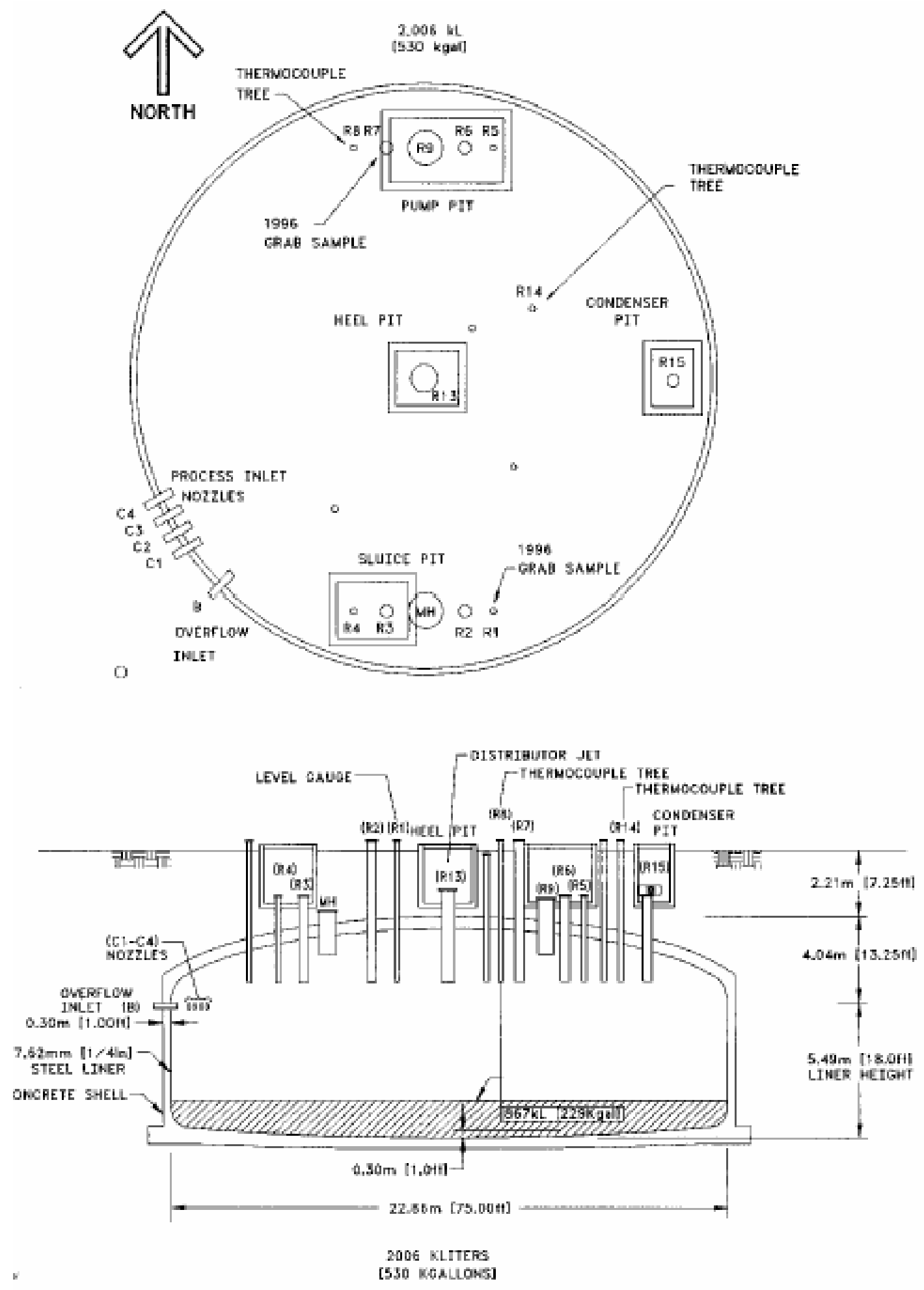

Figure 1.2. Tank C-106 Configuration (Conner 1996) 
In late 2003, sludge from tank C-106 was further removed using a $0.9 \mathrm{M}$ oxalic acid solution to dissolve and suspend the solids and pump out as much as possible. The goal was to lower the sludge volume from about 68,137 to $10,599 \mathrm{~L}\left(18,000\right.$ to 2,800 gal [360 $\left.\left.\mathrm{ft}^{3}\right]\right)$. This goal was achieved by several additions and removals of the oxalic acid solution. After the final removal, the sludge was rinsed with water to remove as much of the acid solution as possible. Approximately 151,416 L (40,000 gal) or $35.5 \mathrm{~cm}$ (14 in.) of water was added to measure the sludge volume, and then as much liquid as possible was removed. A 0.5-M NaOH solution was added to neutralize the residual waste, and then removed. The residual liquid in the tank was sampled for analysis through Riser 14 (Figure 1.2), and multiple sludge samples were acquired using a clamshell device by CH2M HILL Hanford Group, Inc. (CH2M HILL) in January 2004. All samples were delivered to the Hanford 222-S Laboratory for processing and characterization. Figure 1.3 is a picture of the sludge at the 222-S Laboratory. Subsamples were sent to Pacific Northwest National Laboratory (PNNL) for testing and release model development.

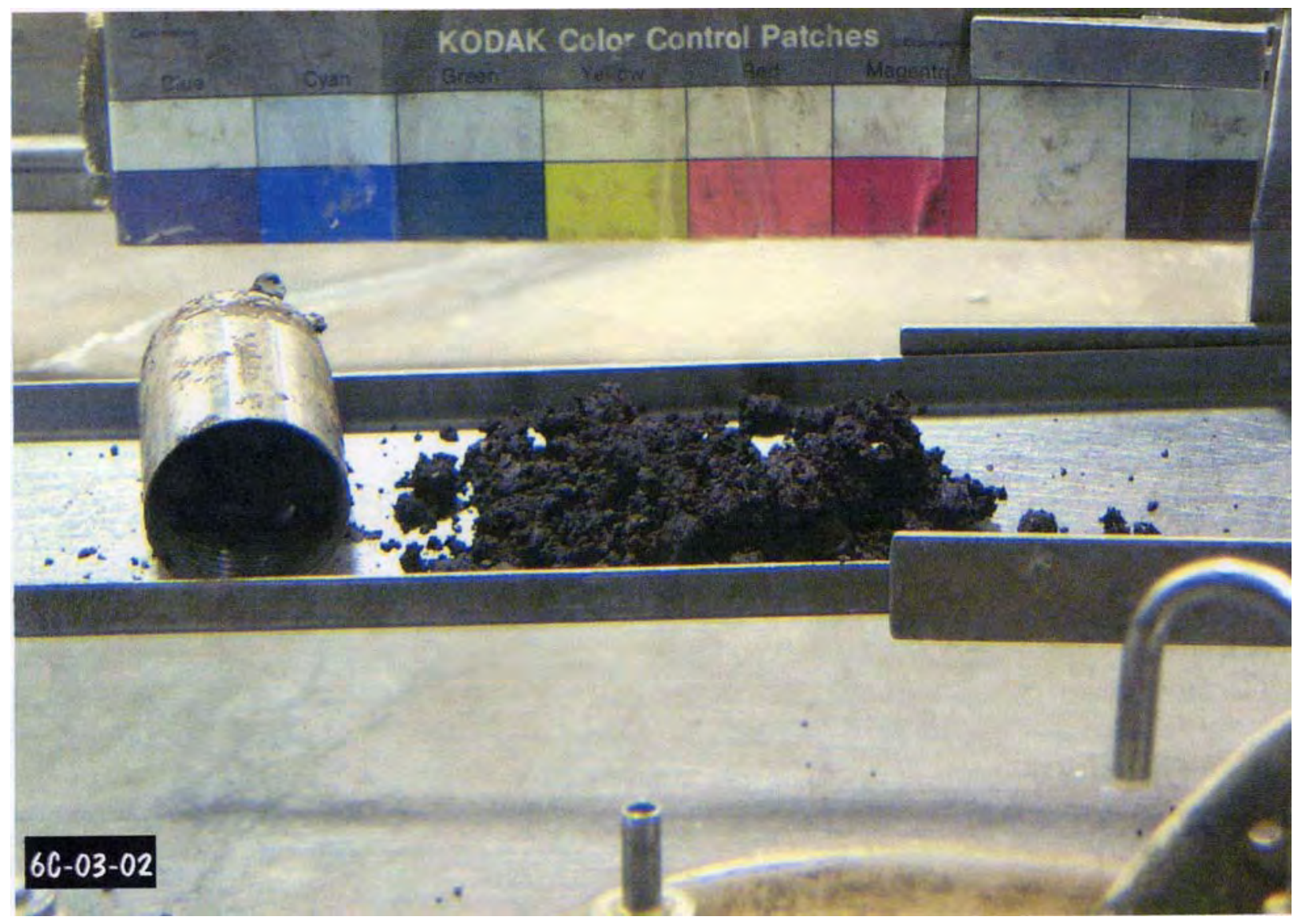

Figure 1.3. Tank C-106 Sludge at 222-S Laboratory 


\subsection{Background}

Fresh cement/grout will contain pore fluids that have high $\mathrm{pH}$ values $(>12)$ and high concentrations of soluble salts. Infiltration will enter the cement/grout initially through pores and then through cracks as the grout ages. At the outset, the most readily soluble salts will leach out, lowering the dissolved concentrations of these salts and the $\mathrm{pH}$ within the cement grout pore fluids. In addition, carbon dioxide will enter the cement as air moves into the pores/fractures and as water with dissolved $\mathrm{CO}_{2}$ migrates through the grout. Carbon dioxide is an acidic gas that forms carbonic acid when it dissolves in water. It will also react with $\mathrm{Ca}(\mathrm{OH})_{2}$ (portlandite) in the cement grout to precipitate calcite $\left(\mathrm{CaCO}_{3}\right)$ and lower the $\mathrm{pH}$.

$$
\mathrm{Ca}(\mathrm{OH})_{2}+2 \mathrm{CO}_{2} \rightarrow \mathrm{CaCO}_{3}+\mathrm{HCO}_{3}^{-}+\mathrm{H}^{+}
$$

Carbonation and calcite precipitation are considered the most common chemical reactions influencing the performance of cement based materials in natural systems. In addition to the formation of calcite from $\mathrm{Ca}(\mathrm{OH})_{2}$, this mineral also forms from decalcification of calcium silicate hydrogel (CSH), which typically constitutes $40 \%$ to $50 \%$ of cement. During this stage of cement weathering, $\mathrm{CO}_{2}(\mathrm{aq})$ decomposes the remaining $\mathrm{CSH}$ gel into $\mathrm{CaCO}_{3}(\mathrm{~s})$, acid-soluble silica gel, and water.

$$
\mathrm{CSH}(\text { gel })+\mathrm{CO}_{2}(\mathrm{aq}) \rightarrow \mathrm{CaCO}_{3}(\mathrm{~s})+\mathrm{SiO}_{2} \text { (gel) }+\mathrm{H}_{2} \mathrm{O}
$$

Eventually, the solutions in contact with aged cement grout come into equilibrium with calcite as the surfaces of the solid become coated with this mineral.

In order to evaluate the impact of a cement-based leaching solution on residual tank sludge, experiments were conducted in which post-retrieval sludge from tank C-106 was leached with a saturated $\mathrm{Ca}(\mathrm{OH})_{2}$ solution followed by a saturated $\mathrm{CaCO}_{3}$ solution. The $\mathrm{Ca}(\mathrm{OH})_{2}(\mathrm{pH} \sim 12.4)$ solution represented the early stages of the cement system in which the grout is relatively fresh, and the $\mathrm{CaCO}_{3}$ solution ( $\mathrm{pH} \sim 8.3$ ) represented the weathered grout system. The compositions of the resulting leachates from the $\mathrm{Ca}(\mathrm{OH})_{2}$ /sludge and $\mathrm{CaCO}_{3} /$ sludge systems have been compared to the previous deionized water leaches to evaluate the relative impact of the various leachants on contaminant mobility.

Several oxalic acid additions were made to tank C-106 during final retrieval of sludge to dissolve and remove as much solids as possible. After the final acid wash, a $0.5-\mathrm{M} \mathrm{NaOH}$ solution was added to the tank to neutralize the system. As much of the solution as possible was then pumped from the tank. The residual tank liquid was sampled as well as the sludge. The results of the PNNL analysis of the residual liquid are shown in Table 2.1. The solution $\mathrm{pH}$ is 12.9 because of the added $\mathrm{NaOH}$. The major cations in solution are $\mathrm{Na}(10,200 \mathrm{mg} / \mathrm{L}$ average) and $\mathrm{Al}(121 \mathrm{mg} / \mathrm{L}$ average), while the major anions are carbonate (9,930 $\mathrm{mg} / \mathrm{L}$ average) and oxalate $\left(1,345 \mathrm{mg} / \mathrm{L}\right.$ average). The MINTEQ calculated total $\mathrm{OH}^{-}$concentration is $2,200 \mathrm{mg} / \mathrm{L}$. Because the $\mathrm{pH}$ of the $\mathrm{Ca}(\mathrm{OH})_{2}$-saturated solution is expected to be similar to that of the pore water in the post-retrieval C-106 sludge, it is likely that $\mathrm{pH}$ will not be a strong driver for reactions with the early cement-dominated system. However, the high calcium concentration in the cement grout leaching solution will likely enhance calcite and, perhaps, calcium oxalate precipitation in the sludge. 
Table 2.1. Sample 403 - Tank C-106 Liquid Sample Composition

\begin{tabular}{|c|c|c|}
\hline \multirow[b]{2}{*}{ Analyte } & \multicolumn{2}{|c|}{ Concentration (mg/L*) } \\
\hline & Primary & Duplicate \\
\hline $\mathrm{pH}$ & 12.9 & \\
\hline \multicolumn{3}{|c|}{ Metals } \\
\hline $\mathrm{Al}$ & 126.0 & 116. \\
\hline $\mathrm{Ba}$ & 3.5 & $(0.09)$ \\
\hline $\mathrm{Ca}$ & 21.9 & $(4.1)$ \\
\hline $\mathrm{Cr}$ & $(0.28)$ & $(0.34)$ \\
\hline $\mathrm{Fe}$ & $(1.9)$ & $(0.6)$ \\
\hline K & (14.) & (12.) \\
\hline $\mathrm{Mg}$ & $(0.9)$ & $(0.24)$ \\
\hline $\mathrm{Mn}$ & $(0.16)$ & $(0.1)$ \\
\hline $\mathrm{Na}$ & $10,300$. & 10,100 \\
\hline $\mathrm{Ni}$ & 3.9 & 3.0 \\
\hline $\mathrm{Si}$ & (158.) & (141.) \\
\hline \multicolumn{3}{|c|}{ Radionuclides } \\
\hline${ }^{99} \mathrm{Tc}$ & 0.0003 & $(0.00012)$ \\
\hline${ }^{238} \mathrm{U}$ & 1.24 & 1.03 \\
\hline${ }^{137} \mathrm{Cs}(\mu \mathrm{Ci} / \mathrm{L})$ & 505 & 442 \\
\hline Total Alpha $(\mu \mathrm{Ci} / \mathrm{L})$ & 30.3 & 30.2 \\
\hline Total Beta $(\mu \mathrm{Ci} / \mathrm{L})$ & 470 & 469 \\
\hline \multicolumn{3}{|c|}{ Anions } \\
\hline Oxalate & 1,340 . & 1,350 . \\
\hline $\mathrm{CO}_{3}{ }^{2-}$ & $10,020$. & $9,840$. \\
\hline $\mathrm{Cl}^{-}$ & 20.5 & 20.5 \\
\hline $\mathrm{NO}_{3}^{-}$ & 9.43 & 9.41 \\
\hline $\mathrm{F}^{-}$ & 1.38 & $<1.17$ \\
\hline $\mathrm{SO}_{4}{ }^{2-}$ & 27.6 & 27.6 \\
\hline $\mathrm{PO}_{4}^{3-}$ & 75.1 & 74.6 \\
\hline
\end{tabular}

XRD analysis of the C-106 sludge samples showed detectable quantities of the following crystalline phases:

- lindbergite $\left[\mathrm{MnC}_{2} \mathrm{O}_{4} \cdot 2 \mathrm{H}_{2} \mathrm{O}\right]$

- gibbsite $\left[\mathrm{Al}(\mathrm{OH})_{3}\right]$

- dawsonite $\left[\mathrm{NaAlCO}_{3}(\mathrm{OH})_{2}\right]$

- hematite $\left(\mathrm{Fe}_{2} \mathrm{O}_{3}\right)$

- böhmite $[\mathrm{AlO}(\mathrm{OH})]$

- rhodochrosite $\left(\mathrm{MnCO}_{3}\right)$

- whewellite (Ca oxalate monohydrate, $\mathrm{CaC}_{2} \mathrm{O}_{4} \cdot \mathrm{H}_{2} \mathrm{O}$ ) 
Except for lindbergite, these minerals were also present in the 1-month water-leached, 82-day waterleached, and hydrofluoric (HF)-extracted sludge samples. The $\mathrm{Ca}(\mathrm{OH})_{2}$-saturated system will likely stabilize the carbonate minerals (dawsonite and rhodochrosite) and have little effect on the solubility of the metal oxide/hydroxide phases (gibbsite, hematite, and böhmite) because the $\mathrm{pH}$ should not change appreciably. The Mn oxalate solid should dissolve in this system, while the solubility of the Ca oxalate will depend on the final $\mathrm{Ca}$ and oxalate concentrations in the mixture of grout leachate and residual pore water.

For the $\mathrm{CaCO}_{3}$-saturated system, it is expected that the carbonate minerals (dawsonite and rhodochrosite) will partially dissolved in the lower $\mathrm{pH}$ environment, and the oxalate minerals (lindbergite and whewellite) will also be soluble because of the lack of oxalate in the leaching solution. The metal oxide and hydroxide minerals (gibbsite, hematite, and böhmite) are not expected to dissolve appreciably in this system because they are relatively insoluble at a $\mathrm{pH}$ of 8.

Deionized water leaches were conducted on C-106 sludges for time periods of 1 day, 2 weeks, and 1 month (Deutsch et al. 2005a). In addition to these single step leaches, sequential water leaches were conducted. In the sequential leaches, the same sludge sample was extracted for periods of 1 to 4 days repeatedly with fresh deionized water for 5 periods in sequence. These same samples were then sequentially leached for periods of 43 and 82 days. All of these leach experiments were conducted using $0.3 \mathrm{~g}$ of sludge and $30 \mathrm{~mL}$ of water. The resulting $\mathrm{pH}$ values of the final solutions from the water leaching tests were in the range of 6.7 to 7.7. The major leachable metals were $\mathrm{Na}$ and $\mathrm{Mn}$. The major leachable anions were oxalate and carbonate. During the planned leaching experiments with $\mathrm{Ca}(\mathrm{OH})_{2}-$ saturated and $\mathrm{CaCO}_{3}$-saturated solutions, it was expected that $\mathrm{Na}$ and $\mathrm{Mn}$ would again be the most leachable metals and oxalate would be a major leachable anion. Carbonate is not expected to be very leachable from the $\mathrm{Ca}(\mathrm{OH})_{2}$-saturated solution, but may be leachable at the lower $\mathrm{pH}$ of the $\mathrm{CaCO}_{3}$ system if soluble carbonate minerals are present.

The primary contaminants of concern in the C-106 sludge are ${ }^{99} \mathrm{Tc},{ }^{238} \mathrm{U},{ }^{129} \mathrm{I}$, and Cr because of their potential mobility in the environment and the long half-lives of the radionuclides. In the deionized water leaches, it was found that only low percentages $(<10 \%)$ of these primary contaminants were readily leachable from the residual waste, probably because of the previous in-tank mobilization and solids removal with oxalic acid during retrieval. 


\subsection{Materials and Laboratory Test Methods}

Sludge and liquid samples from tank C-106 were collected by CH2M HILL during post retrieval activities in January 2004. This section provides a description of the samples and the various tests used to characterize the material, measure contaminant release, and identify controlling solids.

All laboratory activities were conducted in accordance with the requirements of Title 10, Code of Federal Regulations, Part 830.120 “Quality Assurance” and the Hanford Analytical Services Quality Assurance Requirements Document (HASQARD, DOE 1998). These requirements were implemented using PNNL's internal quality assurance (QA) plan. ${ }^{(a)}$ PNNL's QA Plan is based on the requirements of U.S. Department of Energy (DOE) Order 414.1A , the HASQARD, relevant elements of NQA-1-1989 (ASME 1989), as well as recognized industry standards (e.g., U.S. Environmental Protection Agency [EPA], ASTM, American National Standards Institute).

\subsection{Tank C-106 Samples}

On January 26, 2004, after neutralization of tank waste with $\mathrm{NaOH}$ and during pumping of residual fluid from tank C-106, a sample of the liquid was collected and transported to the Hanford 222-S Laboratory for storage and analysis. On January 29, 2004, nine clamshell samples of residual sludge were collected from the tank and sent to the 222-S Laboratory. On January 30 the sludge samples were extruded in the 11A Hot Cell. Part of the extruded samples was combined to produce the Field Primary Solid Composite. The remaining sludge was combined to produce the Field Duplicate Solid Composite. On April 13, 2004, samples of the sludge and liquid were shipped to the PNNL Radiochemical Processing Laboratory (RPL). Table 3.1 lists the samples received by PNNL.

Testing of sludge samples to develop contaminant release models was conducted on Field Primary Solid Composite S04T000404 (primary 404, Figure 3.1) and Field Duplicate Solid Composite S04T000405 (duplicate 405, Figure 3.2). Liquid sample S04T000403 (403) was also analyzed to determine the pore water concentrations of contaminants in the sludge.

Table 3.1. Tank C-106 Samples Provided by 222-S Laboratory to PNNL

\begin{tabular}{||l|c|c|c||}
\hline \multicolumn{1}{|c|}{ Sample } & $\begin{array}{c}\text { Jar Size } \\
(\mathrm{mL})\end{array}$ & $\begin{array}{c}\text { Labcore } \\
\text { Number }\end{array}$ & $\begin{array}{c}\text { Net Weight/Volume of } \\
\text { Material (g) }\end{array}$ \\
\hline \hline Field Primary Solid Composite & 60 & S04T000109 & 20.4 \\
\hline Field Primary Solid Composite & 60 & S04T000404 & 20.6 \\
\hline Field Duplicate Solid Composite & 60 & S04T000405 & 20.1 \\
\hline 6C-03-11 (Liquid) & 60 & S04T000403 & 61.6 \\
\hline
\end{tabular}

(a) PNNL. 2001. Conducting Analytical Work in Support of Regulatory Programs. Internal unpublished procedure, Pacific Northwest National Laboratory, Richland, Washington. 


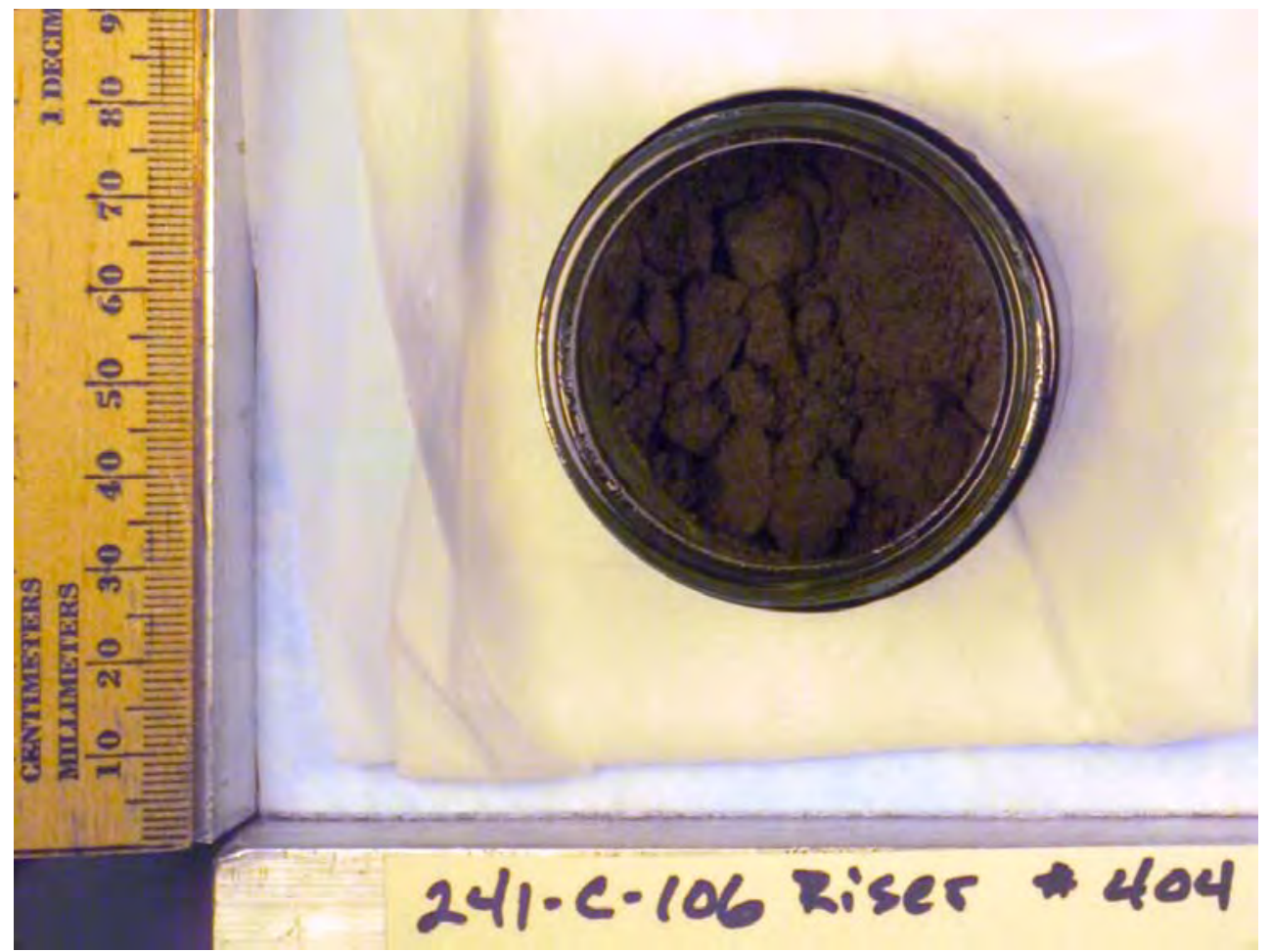

Figure 3.1. Tank C-106 Field Primary Solid Composite Sludge Sample 404

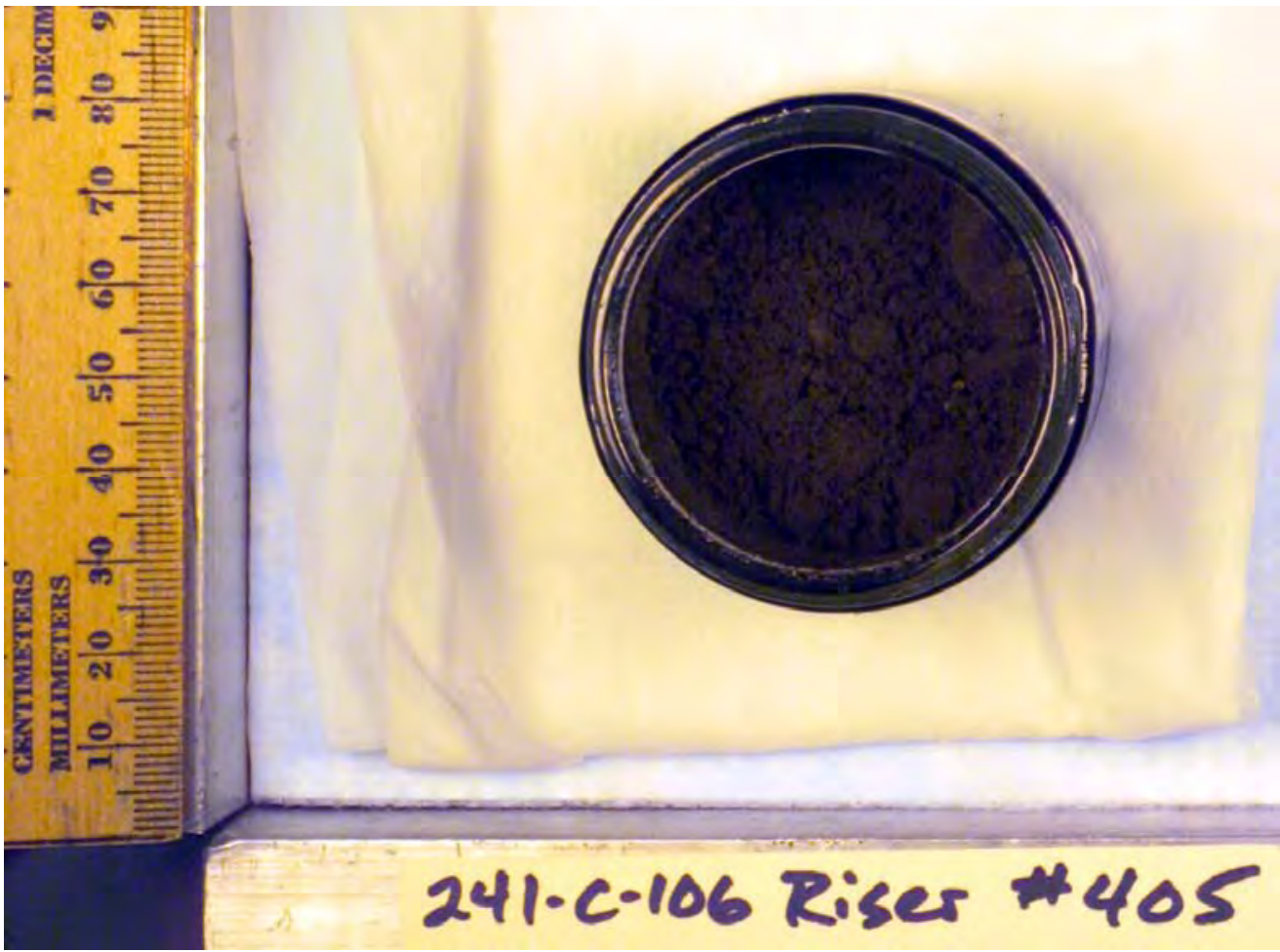

Figure 3.2. Tank C-106 Field Duplicate Solid Composite Sludge Sample 405 


\subsection{Cement Simulation Tests}

Batch and sequential contact leach tests were conducted on C-106 residual sludge samples using $\mathrm{Ca}(\mathrm{OH})_{2}$-saturated and $\mathrm{CaCO}_{3}$-saturated solutions. Figure 3.3 shows the flowpaths of the experiments, which are described in detail in this section.
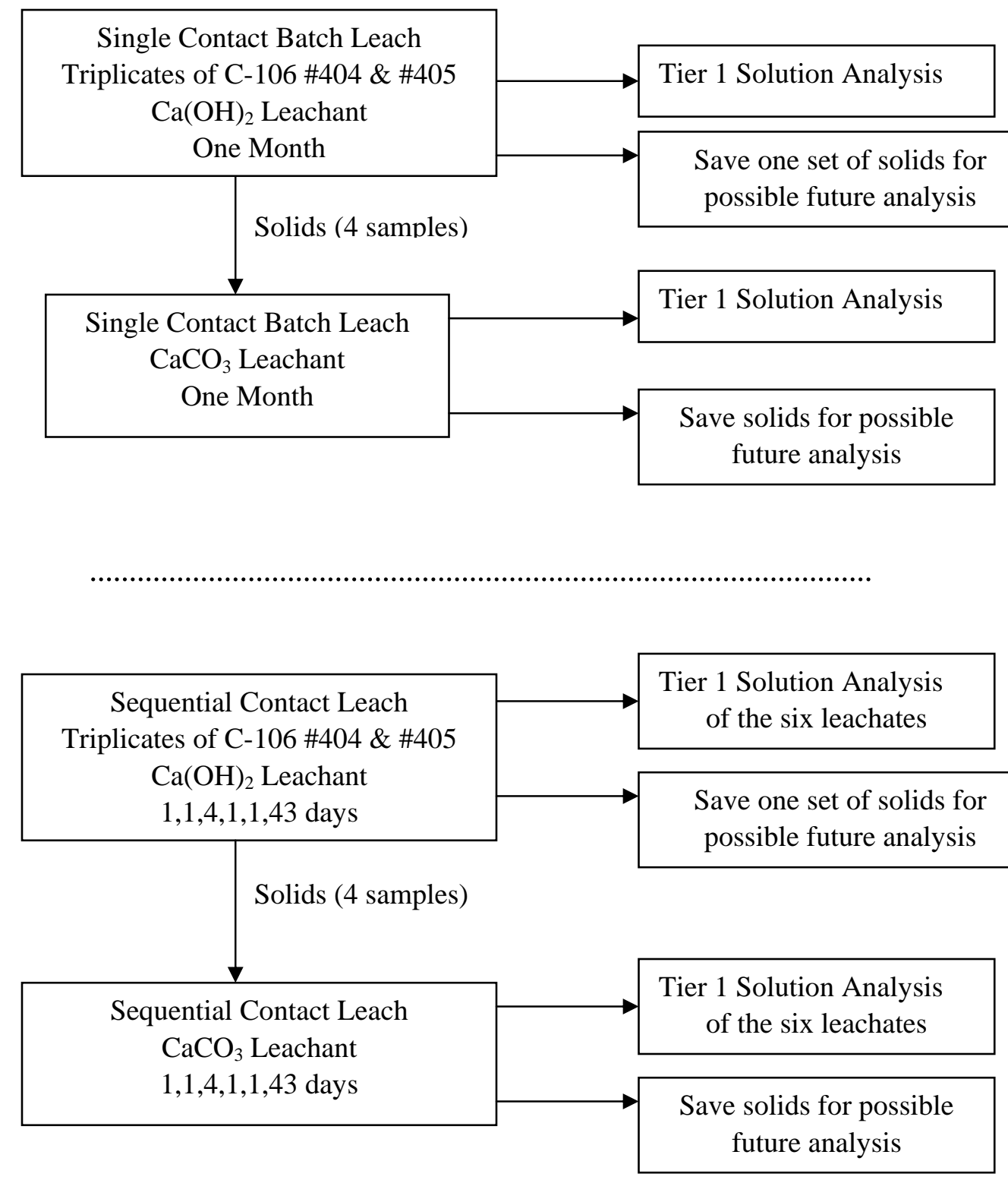

Figure 3.3. Leach Test Flowpath

\section{$\mathrm{Ca}(\mathrm{OH})_{2}$-Saturated Leaching Solution}

A sufficient quantity of fresh $\mathrm{Ca}(\mathrm{OH})_{2}\left(\sim 1.4 \mathrm{~g} / \mathrm{L} @ 25^{\circ} \mathrm{C}\right)$ was added to deionized water to just saturate the solution. Excess solid $\mathrm{Ca}(\mathrm{OH})_{2}$ is undesirable because it will buffer the $\mathrm{pH}$ at a higher than expected value. Because $\mathrm{CO}_{2}$ in air is very soluble in water at high $\mathrm{pH}$ and the resulting dissolved 
carbonate will precipitate as calcite in the $\mathrm{Ca}(\mathrm{OH})_{2}$-saturated solution, care was taken to minimize contact of the solution with atmospheric air. When possible, Teflon containers were used because they have low air diffusion coefficients. Air space in the containers was also minimized and the vessel was tightly sealed to limit leakage of air into the vessel. The $\mathrm{pH}$ of an aliquot of the $\mathrm{Ca}(\mathrm{OH})_{2}$ solution was measured as well as the dissolved calcium concentration.

\section{Calcite-Saturated Leaching Solution}

The calcite-saturated solution was prepared by adding excess powdered calcite to deionized water and stirring or shaking the mixture for 24 hours. The temperature during equilibration was a few degrees above room temperature. By preparing the solution at a slightly elevated temperature the possibility of calcite precipitation during the test at room temperature was minimized. (Calcite undergoes retrograde solubility.) There was no need to minimize contact of this solution with the atmosphere. After the solution was prepared, the $\mathrm{pH}$ value and calcium and carbonate concentrations were measured and compared to expected equilibrium values and concentrations $\left[\mathrm{pH}=8.3, \mathrm{Ca}^{2+}=20 \mathrm{mg} / \mathrm{L}, \mathrm{TIC}=58 \mathrm{mg} / \mathrm{L}\right.$, $\mathrm{P}_{\mathrm{CO} 2}=0.0003 \mathrm{~atm}$ (fixed) $]$.

\subsubsection{Moisture Content}

The moisture contents of the tank waste samples were measured to calculate dry weight concentrations for constituents in the waste. Dry weight concentrations provide a consistent measurement unit for comparison purposes that eliminates the effect of variable water content on sample concentrations.

Gravimetric water content of the waste material was determined using ASTM procedure D2216-98, Standard Test Method for Laboratory Determination of Water (Moisture) Content of Soil and Rock by Mass (ASTM 1998) with the following minor exceptions: (1) the volume of sample recommended was decreased due to radiological concerns and (2) the sample was dried at a lower oven temperature, $105^{\circ} \mathrm{C}$, for a longer period of time to prevent dehydration of the solids.

Sludge samples were placed in tarred containers, weighed, and dried in an oven until a constant weight was achieved, usually requiring 24 to 48 hours. The container was then removed from the oven, sealed, cooled, and weighed. All weighings were performed using a calibrated balance. The gravimetric water content is computed as the percentage change in soil weight before and after oven drying (i.e., [ \{wet weight - dry weight $\} /$ dry weight $]$ ).

\subsubsection{Single Contact Batch Leaching Test}

In this test, $0.3 \mathrm{~g}$ of $\mathrm{C}$-106 sludge were added to $30 \mathrm{~mL}$ of a $\mathrm{Ca}(\mathrm{OH})_{2}$-saturated solution and leached in the same fashion as was done in the Tier 1 water leaches (Deutsch et al. 2005a). Triplicate samples of C-106 sludges \#404 and \#405 were tested. Because there were not significant differences in the 1 day, two week, and 1 month water leaches, this test was only conducted for a time period of one month. The leachates from these experiments were analyzed for the same parameters that were measured in the Tier 1 water-leaching experiments. After leaching, two of the samples of remaining solid materials were saved for the single contact batch-leaching tests using the $\mathrm{CaCO}_{3}$ leaching solution described in the following paragraph. The third sample was saved for possible future XRD/SEM/EDS analysis. None of these solids were used for the sequential leaches described in the following section. This will allow a 
comparison to be made of the results of the 1-month single contact test and the first day of the sequential leach to confirm that contact time does not affect the results.

Two of the final solids from the single contact $\mathrm{Ca}(\mathrm{OH})_{2}$ leaching tests were added to $30 \mathrm{~mL}$ of the $\mathrm{CaCO}_{3}$-saturated solution and leached in the same fashion as was done for the other single contact tests. Duplicate samples of C-106 sludge \#404 and \#405 were tested. The contact time was 1 month. The leachates from these experiments were analyzed for the same parameters that were measured in the Tier 1 water-leaching experiments. After leaching, the remaining solid materials were saved for possible future XRD and SEM analysis.

\subsubsection{Sequential Contact Leaching Test}

Because there were significant differences in the early stages of the sequential water leaches (primarily depletion of $\mathrm{Na}, \mathrm{Mn}$, and oxalate), the sequential leach tests mimicked the deionized water tests and were conducted for time periods of 1, 1, 4, 1, 1, and 43 days (Figure 3.3). (The long-term 82-day leach was not necessary because the results of the deionized water leach test were not that different than observed in the 43-day test.) In the sequential contact leaching tests, $0.3 \mathrm{~g}$ of triplicate fresh samples of \#404 and \#405 C-106 sludge were added to $30 \mathrm{~mL}$ of a $\mathrm{Ca}(\mathrm{OH})_{2}$-saturated solution and leached for the stated periods of time. The leachates from these experiments were analyzed for the same parameters that were measured in the Tier 1 water-leaching experiments. After leaching, two of the three remaining solid materials were saved for the second phase of these leach tests using the $\mathrm{CaCO}_{3}$ leachant. The third sample was saved for possible future XRD/SEM/EDS analysis.

The final solids from the sequential $\mathrm{Ca}(\mathrm{OH})_{2}$ leach tests were used for the $\mathrm{CaCO}_{3}$ leach tests. These tests were also conducted using $30 \mathrm{~mL}$ of the $\mathrm{CaCO}_{3}$-saturated solution as the leachant for time periods of $1,1,4,1,1$, and 43 days. The leachates from these experiments were analyzed for the same parameters that were measured in the Tier 1 water-leaching experiments. After leaching, the remaining solid materials were saved for possible future XRD and SEM analysis.

\subsection{4 $\quad$ pH}

The $\mathrm{pH}$ values of the solutions were measured using a solid-state $\mathrm{pH}$ electrode and a $\mathrm{pH}$ meter calibrated with buffers bracketing the expected range. This measurement is similar to EPA Method 9040B (EPA 1995).

\subsubsection{Anion Analysis}

Anion analysis was performed using an ion chromatograph. Fluoride, acetate, formate, chloride, nitrite, bromide, nitrate, carbonate, sulfate, oxalate, and phosphate were separated on a Dionex AS17 column with a gradient elution technique from $1 \mathrm{mM}$ to $35 \mathrm{mM} \mathrm{NaOH}$ and measured using a conductivity detector. This methodology is similar to EPA Method 9056A (EPA 1994b) with the exception of using gradient elution with $\mathrm{NaOH}$.

\subsubsection{Cations and Trace Metals}

Major cation analysis (including $\mathrm{Al}, \mathrm{Ca}, \mathrm{Fe}, \mathrm{K}, \mathrm{Mg}, \mathrm{Mn}, \mathrm{Na}$, and $\mathrm{Si}$ ) was performed by inductively coupled plasma-optical emission spectroscopy (ICP-OES) EPA Method 6010B (EPA 1996). 
Radiochemical analysis for ${ }^{99} \mathrm{Tc},{ }^{238} \mathrm{U},{ }^{239} \mathrm{Pu},{ }^{241} \mathrm{Am},{ }^{237} \mathrm{~Np}$ and ${ }^{129} \mathrm{I}$ was performed by inductively coupled plasma-mass spectroscopy (ICP-MS). This method is similar to EPA Method 6020 (EPA 1994a). For both ICP-OES and ICP-MS, high-purity calibration standards were used to generate calibration curves and to verify continuing calibration during the analysis. Multiple dilutions of selected samples (ranging from $3 \mathrm{x}$ to $100 \mathrm{x}$ ) were made and analyzed to investigate and correct for matrix interferences.

\subsubsection{Alkalinity}

The sample alkalinity was measured by standard titration. A volume of standardized sulfuric acid $\left(\mathrm{H}_{2} \mathrm{SO}_{4}\right)$ was added to the sample to an endpoint of $\mathrm{pH}$ 4.5. The volume of $\mathrm{H}_{2} \mathrm{SO}_{4}$ needed to achieve the endpoint is used to calculate the total $\left(\mathrm{OH}^{-}+\mathrm{HCO}_{3}{ }^{-}+\mathrm{CO}_{3}{ }^{2-}\right)$ alkalinity as calcium carbonate $\left(\mathrm{CaCO}_{3}\right)$. The alkalinity procedure is similar to Standard Method 2320 B (Clesceri et al. 1998).

\subsubsection{Radioanalysis}

In addition to the radionuclides listed in Section 3.2.6 that were analyzed in solution by ICP-MS, short-lived radionuclides were analyzed by conventional counting methods as described in the following sections.

\subsubsection{Gamma Energy Analysis}

All samples for gamma energy analysis (GEA) were analyzed using 60\% efficient intrinsicgermanium gamma detectors. All germanium counters were efficiency calibrated for distinct geometries using mixed gamma standards traceable to the National Institute of Standards and Technology (NIST). Direct solids, acid extracts, and water extracts were analyzed for gamma energy. Spectral analysis was conducted using libraries containing most mixed-fission products, activation products, and natural decay products. Control samples were run throughout the analysis to ensure correct operation of the detectors. The controls contained isotopes with photo peaks spanning the full detector range and were monitored for peak position, counting rate, and full-width half-maximum. Details are found in PNNL internal procedure AGG-RRL-001. ${ }^{\text {(a.) }}$

\subsubsection{2 $\quad{ }^{90} \mathrm{Sr}$ Analyses}

Aliquots of filtered acid extracts, fusions, and water extracts were diluted in $8 \mathrm{M} \mathrm{HNO}_{3}$ and submitted for strontium separation and analysis by internal PNNL procedure AGG-RRL-003.2. ${ }^{\text {(b) }}$ A 0.1 to $5 \mathrm{~mL}$ aliquot of sample was spiked with ${ }^{85} \mathrm{Sr}$ tracer and passed through a SrSpec ${ }^{\circledR}$ column (Eichrom Technologies, Chicago) to capture Sr. The columns were washed with 10 column volumes $(20 \mathrm{~mL})$ of $8 \mathrm{M} \mathrm{HNO}_{3}$. The strontium was eluted from the SrSpec column into glass liquid scintillation vials using $15 \mathrm{~mL}$ of deionized water. The vials were placed under a heat lamp overnight to evaporate the water to dryness. A $15 \mathrm{~mL}$ Optifluor ${ }^{\circledR}$ scintillation cocktail was added to each vial. Gamma spectroscopy was used to determine the chemical yield from the added ${ }^{85} \mathrm{Sr}$ tracer. The samples were then analyzed by liquid scintillation counting (LSC) to determine the amount of ${ }^{90} \mathrm{Sr}$ originally present in the sludge

(a) AGG-RRL-001, 2004 Gamma Energy Analysis, Operation, and Instrument Verification using Genie2000 Support Software, Technical Procedure, Pacific Northwest National Laboratory, Richland, Washington.

(b) AGG-RRL-003.2. 2000. Tc99 and Sr90 Analysis using Eichrom TEVA-spec and Sr-spec Resin. Technical Procedure, Pacific Northwest National Laboratory, Richland, Washington. 
sample. A matrix spike, a blank spike, a duplicate, and blanks were run with each sample set to determine the efficiency of the separation procedure as well as the purity of reagents.

\subsection{XRD Analysis}

Crystalline phases present in the 1-month and Stage 6 sequential samples of residual waste from tank C-106 leached with $\mathrm{Ca}(\mathrm{OH})_{2}$ and $\mathrm{Ca}(\mathrm{OH})_{2} / \mathrm{CaCO}_{3}$ were characterized by standard powder XRD techniques. Because the sludge materials were highly radioactive, dispersible powders, it was necessary to prepare the XRD mounts of these samples inside a fumehood regulated for handling radioactive materials. Sludge samples were prepared for XRD analysis by placing a milligram quantity of each sample and a trace quantity of reference-material corundum powder $\left(\alpha-\mathrm{Al}_{2} \mathrm{O}_{3}\right.$, alumina) (NIST Standard Reference Material [NIST SRM] 676) into a mixture of water and collodion solution. The collodion solution consists of $2 \%$ nitrocellulose dissolved in amyl acetate, and is an x-ray amorphous, viscous binder commonly used to make random powder mounts for XRD when only a limited amount of sample is available. The addition of trace quantities of reference-material corundum powder to each slurry provided an internal $2 \theta$ standard for each XRD pattern. Using a pipette, each slurry was transferred onto a circular-shaped platform (1-cm diameter) and placed on top of the post located on the base inside a disposable XRD specimen holder (Figure 3.4). This specimen holder was designed specifically for safe handling of dispersible powders containing highly radioactive or hazardous materials (Strachan et al. 2003). After allowing samples to air dry overnight, the holder was assembled and a piece of Kapton ${ }^{\circledR}$ film was placed between the cap and the retainer. The holder was sealed with wicking glue and removed from the fumehood.

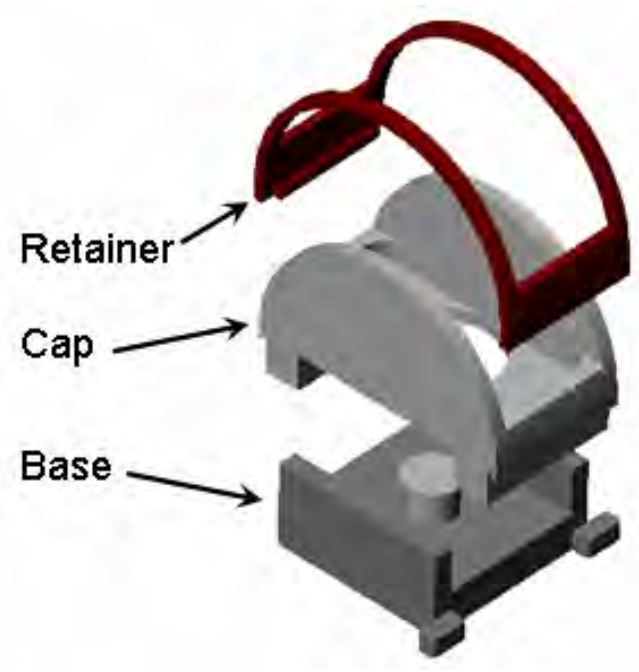

Figure 3.4. Exploded Schematic View of the XRD Sample Holder (Kapton ${ }^{\circledR}$ film not shown)

Each sample was analyzed using a Scintag XRD unit equipped with a Peltier thermoelectricallythermoelectrically-cooled detector and a copper x-ray tube. The diffractometer was operated at $45 \mathrm{kV}$ and $40 \mathrm{~mA}$. Individual scans were obtained from 2 to $65^{\circ} 2 \theta$ with a dwell time of 4 and 14 seconds. Scans were collected electronically and processed using the JADE ${ }^{\circledR}$ XRD pattern-processing software. 
Krupka et al. (2004) prepared and analyzed by XRD a sample consisting of only a dry film of the collodion solution so that its contribution relative to the background signals of the XRD patterns for the sludge samples could be quantified. The resulting XRD pattern for the collodion solution film is shown in Figure 3.5. The most obvious feature of this diffraction pattern is the broad peak positioned between $10^{\circ}$ and $30^{\circ} 2 \theta$. The symmetry of this peak is characteristic of those resulting from the XRD of amorphous (noncrystalline) material. Although subtracting the collodion background from sludge XRD patterns allows for better phase matching, this process may eliminate minor reflections and inconspicuous features of a pattern. Therefore, each as-measured XRD pattern was examined before and after background subtraction to ensure that the integrity of the pattern was maintained. For background subtraction, the JADE ${ }^{\circledR}$ software provides the user with control over the selection of background-subtraction points. This process allows a better fit to $2 \theta$ regions under broad reflections, such as those resulting from amorphous materials. On average, 30 to 40 background points were selected from each XRD pattern, and a cubic-spline curve was then fit through each set of points. Adjustments to this curve were made by selecting additional background points in regions of a pattern that were difficult to fit. Once a wellmatched curve was fitted to a pattern, the background was subtracted from each as-measured XRD pattern, resulting in a smooth tracing.

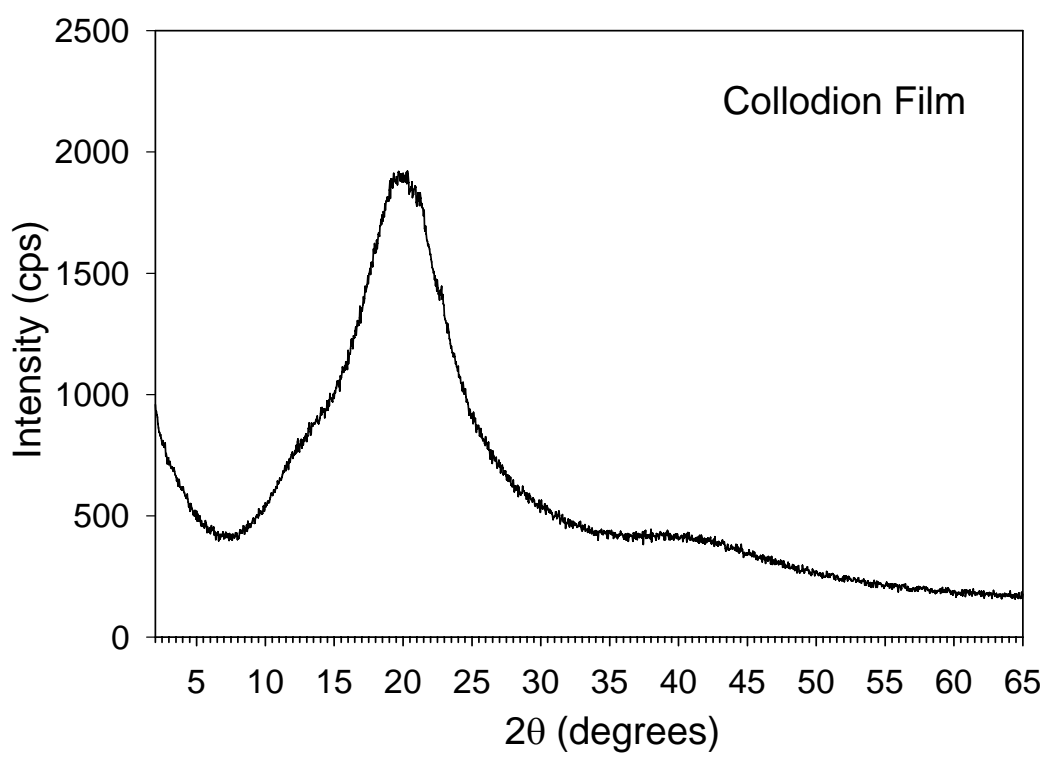

Figure 3.5. XRD Pattern for Collodion Film Measured in the Absence of any Sludge Material (from Krupka et al. 2004)

Identification of the mineral phases in the background-subtracted patterns was based on a comparison of the XRD patterns measured for the sludge samples with the mineral powder diffraction files (PDFTM) published by the Joint Committee on Powder Diffraction Standards (JCPDS) International Center for Diffraction Data (ICDD). As a rule of thumb, a crystalline phase must be present at greater than $5 \mathrm{wt} \%$ of the total sample mass (greater than $1 \mathrm{wt} \%$ under optimum conditions) to be readily detected by XRD. In general, the measured peak intensities depend on several factors, including the combined mass of each crystalline phase in the sample. Due to the physical characteristics of these tank sludge samples such as high radioactivity, high dispersibility, and variable moisture content, the mass of tank sludge combined with the collodion solution for each XRD mount could not be controlled or easily determined. Dissimilarities in mineral segregation (settling) resulting from the different densities of minerals mixed with the 
collodion solution and associated effects on relative peak intensities also influence the overall pattern intensity. The combined effect of these factors could have some effect on the characteristic mineral peak intensities, which precluded quantitative comparisons of peak intensities for equivalent reflections in background-subtracted XRD patterns for different sludge samples.

\subsection{SEM/EDS Analysis}

The morphologies, sizes, surface textures, and compositions of phases present in the 1-month and Stage 6 sequential samples of residual waste from tank C-106 leached with $\mathrm{Ca}(\mathrm{OH})_{2}$ and $\mathrm{Ca}(\mathrm{OH})_{2} / \mathrm{CaCO}_{3}$ were studied by SEM/EDS and EDS element mapping. Two or three mounts were prepared of each sample to compensate for the possibility that one or more less-than-optimum mounts of a sample might occur, thus improving the likelihood of obtaining representative SEM images of each sample. The mounts used for SEM/EDS consisted of double-sided carbon tape attached to standard aluminum mounting stubs. For each mount, small aliquots of each sludge sample were placed on the exposed upper surface of the carbon tape using a micro spatula. Each mount was then coated with carbon using a vacuum sputter-coater to improve the conductivity of the samples and thus the quality of the SEM images and EDS signals.

A JEOL JSM-840 SEM was used for high-resolution imaging of micrometer/submicrometer-size particles from the sludge samples. The SEM system is equipped with an Oxford ${ }^{(a)}$ INCA EDS software system that was used for semi-qualitative element analysis. As noted in Deutsch et al. (2005b), the JEOL JSM-840 SEM was upgraded in late calendar year 2005 to the Oxford INCA software to automate the collection of EDS spectra over multi-micrometer-size areas of an SEM-imaged sample. This upgrade permits the mapping of the spatial distributions over user-selected areas and/or lines of the relative concentrations of any user-specified element detectable by EDS. Operating conditions for the SEM/EDS analyses consisted of 10 to $20 \mathrm{keV}$ for SEM imaging, and 20-30 keV, 100 live seconds $^{(\mathrm{b})}$ for the EDS analyses.

The EDS analyses of particles are limited to elements with atomic weights heavier than boron. Photomicrographs of high-resolution secondary electron (SE) images and backscattered electron (BSE) images were obtained as digital images and stored in electronic format. To help identify particles that contain elements with large atomic numbers, such as uranium, the SEM was typically operated in the BSE mode. Secondary electrons are low-energy electrons ejected from the probed specimen as a result of inelastic collisions with beam electrons, whereas backscattered electrons are primary electrons emitted as a result of elastic collisions. Backscattered electron emission intensity is a function of the element's atomic number - the larger the atomic number, the brighter the signal. Backscattered electron images are obtained in exactly the same way as secondary electron images.

The SEM micrographs included in the main body of this report (Section 4.3) were selected because they show typical morphologies, sizes, and surface textures of particles in the sludge subsample mounts. All of the SEM micrographs and EDS spectra determined for samples of 1-month and Stage 6 sequential

(a) Oxford Instruments, Concord, Massachusetts.

(b) Live time is when (real time less dead time) the EDS system is available to detect incoming x-ray photons. Dead time is the portion of the total analyzing time that is actually spent processing or measuring x-rays. While each x-ray pulse is being measured, the system cannot measure another x-ray that may enter the detector and is, therefore, said to be "dead." 
samples of residual waste from tank C-106 leached with $\mathrm{Ca}(\mathrm{OH})_{2}-$ and $\mathrm{Ca}(\mathrm{OH})_{2} / \mathrm{CaCO}_{3}$ are shown in Appendices B through D at the end of this report. The entire area of each SEM mount was examined by SEM at low magnification (typically 50 to 100x) to identify those particles and surface features that were typical or unusual for the sample. During this examination, SEM micrographs were recorded at low magnification (e.g., 100x) for typically one or two areas of the mount to show a general perspective of the sizes, types, and distributions of particles that make up the SEM mount. Within these imaged regions, additional SEM micrographs were recorded of several particles at greater magnifications to provide a more detailed representation of the particles' characteristics, and selected points on these particles then analyzed by EDS. Depending on the perceived importance of such particles, regions on these particles were sometimes analyzed by SEM and EDS at even greater magnifications. Compositions determined by EDS are qualitative and have large uncertainties resulting from alignment artifacts caused by the variable sample and detector configurations that exist when different particles are imaged by SEM. 


\subsection{Analytical Results}

This section provides the results of the cement simulant leach tests conducted on sludge samples from tank C-106. These results are compared to the double deionized (DDI) water leach data as well as the fusion data presented in Deutsch et al. (2005a). The discussion begins with the results of the single contact batch leaching tests in Section 4.1.1 followed by the results of the sequential contact leach test (Section 4.1.2), x-ray diffraction analyses (Section 4.2) and SEM/EDS analyses (Section 4.3).

\subsection{Leaching Tests}

The results of the leaching tests of sludge samples are discussed in this section. These include results from the single contact batch leaching and sequential contact leaching tests. Concentration values in this section are given in terms of $\mu \mathrm{g}$ or $\mu \mathrm{Ci}$ per gram of dry sludge. The data are presented in tabular form with a comparison of results from the DDI water leach to the $\mathrm{Ca}(\mathrm{OH})_{2}$ and the $\mathrm{CaCO}_{3}$ leaches.

\subsubsection{Single Contact Batch Leaching}

\subsubsection{Digestion Factors and Moisture Contents}

The digestion factors for the tank C-106 404 and 405 sludge samples used for the DDI water extract varied from 7 to $13.5 \mathrm{~g} / \mathrm{L}$. The digestion factors for the same sludges used for the $\mathrm{Ca}(\mathrm{OH})_{2}$ and the $\mathrm{CaCO}_{3}$ leaches varied from 8.8 to 11.8. These digestion factors are the ratios of wet weight of sludge to $30 \mathrm{~mL}$ of the leachate used to dissolve the soluble portion of the solid. The digestion factors were then multiplied by the percent solids, as determined from moisture content analysis, to convert to a dry weight basis. The variability is a function of the mass of sludge used, which ranged from approximately 0.2 to $0.4 \mathrm{~g}$. The moisture contents averaged about $50.5 \%$ for the C-106 samples used in the DDI water extraction and $12.1 \%$ for the samples used in the $\mathrm{Ca}(\mathrm{OH})_{2}$ and the $\mathrm{CaCO}_{3}$ leaches.

\subsubsection{2 pH and Alkalinity - Single Contact Batch Leaching}

The range of $\mathrm{pH}$ and alkalinity values for the sludge sample extracts is listed in Table 4.1. The $\mathrm{pH}$ values for the 1-month single contact water leach test were in the range of 7.00 to 7.42. $\mathrm{pH}$ values for the 1-month single contact leaching tests using $\mathrm{Ca}(\mathrm{OH})_{2}$ and $\mathrm{CaCO}_{3}$ are not available; however, the values for Stage 6 (43-day contact) of the sequential contact leach tests using $\mathrm{Ca}(\mathrm{OH})_{2}$ and $\mathrm{CaCO}_{3}$ were 11.98 to 12.23 and 11.54 to 11.75 , respectively. These high $\mathrm{pH}$ values represent the highly alkaline condition of the $\mathrm{Ca}(\mathrm{OH})_{2}$ leaching solution. Apparently the high alkalinity is not significantly reduced by six stages of leaching with the $\mathrm{CaCO}_{3}$ solution.

The total alkalinities of the extracts reported in units of $\mathrm{mg} \mathrm{CaCO}_{3} / \mathrm{g}$ sludge are also shown in Table 4.1. The range of the DDI water extract was 14.8 to 23.9 compared to 406 to 740 for the $\mathrm{Ca}(\mathrm{OH})_{2}$ tests and 337 to 418 for the $\mathrm{CaCO}_{3}$ tests. The higher value for the $\mathrm{Ca}(\mathrm{OH})_{2}$ and the $\mathrm{CaCO}_{3}$ leaches are attributable to the composition of the leaching solutions and not to material released from the sludge. 
Table 4.1. Water Extract pH and Alkalinity Values Corrected to Grams of Dry Sludge

\begin{tabular}{||l|c|c||}
\hline \multicolumn{1}{|c|}{ Sample Number } & $\mathrm{pH}$ & $\begin{array}{c}\text { Total Alkalinity as } \mathrm{CaCO}_{3} \text { at } \\
\mathrm{pH} 4.5 \text { Endpoint (mg/g) }\end{array}$ \\
\hline \hline C-106 Water Leach Range, 1 month & 7.00 to 7.42 & 14.8 to 23.9 \\
\hline $\mathrm{C}-106 \mathrm{Ca}(\mathrm{OH})_{2}$ Range, 1 month & 11.98 to $12.23 *$ & 406 to 740 \\
\hline $\mathrm{C}-106 \mathrm{CaCO}_{3}$ Range, 1 month & 11.54 to $11.75^{*}$ & 337 to 418 \\
\hline *pH values measured for Stage 6 of the selective extractions. \\
\hline
\end{tabular}

\subsubsection{3 $\quad{ }^{99} \mathrm{Tc},{ }^{238} \mathrm{U}$, and ${ }^{129} \mathrm{I}$ - Single Contact Batch Leaching}

${ }^{99} \mathrm{Tc},{ }^{238} \mathrm{U}$, and ${ }^{129} \mathrm{I}$ are important potential long-term risk constituents in tank sludge because of their long half-lives and high mobility once dissolved in water. Table 4.2 lists the concentrations of these radionuclides in units of $\mu \mathrm{g}$ leached/g solid and $\mu \mathrm{Ci}$ leached/g solid for the single-contact extracts. Table 4.3 lists the percentage of the total ${ }^{99} \mathrm{Tc},{ }^{238} \mathrm{U}$, and ${ }^{129} \mathrm{I}$ leached from the sludge by each leach test versus the total available concentration given by the fusion analysis reported in Deutsch et al. (2005a). The water-leachable amount of ${ }^{99} \mathrm{Tc}$ ranges from 0.034 to $0.0322 \mu \mathrm{g} / \mathrm{g}$, which is 2.4 to $3.2 \%$ of the total ${ }^{99} \mathrm{Tc}$. For the simulated cement leachate sample the soluble ${ }^{99} \mathrm{Tc}$ ranged from 0.112 to $0.131 \mu \mathrm{g} / \mathrm{g}$ (8.6 to $11.8 \%$ of the available ${ }^{99} \mathrm{Tc}$ ) for the $\mathrm{Ca}(\mathrm{OH})_{2}$ leachate and was not detectable in the $\mathrm{CaCO}_{3}$ leachate.

Table 4.2. ${ }^{99} \mathrm{Tc},{ }^{238} \mathrm{U}$, and ${ }^{129} \mathrm{I}$ Concentrations Leached During Single-Contact Batch Tests

\begin{tabular}{||l|c|c|c|c|c|c||}
\hline \hline & $\begin{array}{c}{ }^{99} \mathrm{Tc} \\
(\mu \mathrm{Ci} / \mathrm{g})\end{array}$ & $\begin{array}{c}{ }^{99} \mathrm{Tc} \\
(\mu \mathrm{g} / \mathrm{g})\end{array}$ & $\begin{array}{c}{ }^{238} \mathrm{U} \\
(\mu \mathrm{Ci} / \mathrm{g})\end{array}$ & $\begin{array}{c}{ }^{238} \mathrm{U} \\
(\mu \mathrm{g} / \mathrm{g})\end{array}$ & $\begin{array}{c}{ }^{129} \mathrm{I} \\
(\mu \mathrm{Ci} / \mathrm{g})\end{array}$ & $\begin{array}{c}{ }^{129} \mathrm{I} \\
(\mu \mathrm{g} / \mathrm{g})\end{array}$ \\
\hline \hline C-106 Water Leach & $5.17 \mathrm{E}-04$ to & $3.04 \mathrm{E}-02$ to & $1.04 \mathrm{E}-06$ to & $3.04 \mathrm{E}+00$ to & & \\
Range, 1 month & $5.80 \mathrm{E}-04$ & $3.22 \mathrm{E}-02$ & $1.26 \mathrm{E}-06$ & $3.70 \mathrm{E}+00$ & $<7.70 \mathrm{E}-06$ & $<4.36 \mathrm{E}-02$ \\
C-106 Ca(OH $)_{2}$ & $1.91 \mathrm{E}-03$ to & $1.12 \mathrm{E}-01$ to & $\begin{array}{c}8.44 \mathrm{E}-07 \text { to } \\
\text { Range, } 1 \text { month }\end{array}$ & $2.48 \mathrm{E}+00$ to & & \\
R-106 CaCO3 Range, & & $1.31 \mathrm{E}-01$ & $2.56 \mathrm{E}-06$ & $7.53 \mathrm{E}+00$ & $<2.18 \mathrm{E}-05$ & $<1.23 \mathrm{E}-01$ \\
C-106 & & $1.79 \mathrm{E}-06$ to & $5.26 \mathrm{E}+00$ to & & \\
1 month & $<1.04 \mathrm{E}-03$ & $<6.12 \mathrm{E}-02$ & $2.96 \mathrm{E}-06$ & $8.72 \mathrm{E}+00$ & NA & NA \\
\hline \hline
\end{tabular}

Table 4.3. Leachable Percentages of ${ }^{99} \mathrm{Tc},{ }^{238} \mathrm{U}$, and ${ }^{129} \mathrm{I}$ in C-106 Sludge Samples Compared with Fusion Results

\begin{tabular}{||l|c|c|c||}
\hline & ${ }^{99} \mathrm{Tc}$ & ${ }^{238} \mathrm{U}$ & ${ }^{129} \mathrm{I}$ \\
\cline { 2 - 4 } & \multicolumn{3}{|c||}{ (\% Leachable) } \\
\hline \hline C-106 Water Leach Range, 1 month & 2.4 to 3.2 & 1.3 to 1.4 & $<1.1$ \\
\hline C-106 $\mathrm{Ca}(\mathrm{OH})_{2}$ Range, 1 month & 8.6 to 11.8 & 1.8 to 2.9 & $<3.1$ \\
\hline C-106 $\mathrm{CaCO}_{3}$ Range, 1 month & $<6.0$ & 2.2 to 3.4 & NA \\
\hline
\end{tabular}

The water-leachable amount of ${ }^{238} \mathrm{U}$ ranged from 3.04 to $3.70 \mu \mathrm{g} / \mathrm{g}$, which is 1.3 to $1.4 \%$ of the total ${ }^{238} \mathrm{U}$. For the simulated cement leachate sample, the soluble ${ }^{238} \mathrm{U}$ ranged from 2.48 to $7.53 \mu \mathrm{g} / \mathrm{g}$ (1.8 to $2.9 \%$ of the available ${ }^{238} \mathrm{U}$ ) for the $\mathrm{Ca}(\mathrm{OH})_{2}$ leachate and 5.26 to $8.72 \mu \mathrm{g} / \mathrm{g}$ (2.2 to $3.4 \%$ of the available ${ }^{238} \mathrm{U}$ ) for the $\mathrm{CaCO}_{3}$ leachate. There was no detectable ${ }^{129} \mathrm{I}$ in DDI water or simulated cement leaches. 


\subsubsection{Selected Metal Concentrations - Single Contact Batch Test}

Metals detected at measurable concentrations in one or more samples are listed in Table 4.4. The water extracts show that $\mathrm{Na}$ and $\mathrm{Mn}$ are the primary water-soluble constituents with much smaller amounts of $\mathrm{Ba}, \mathrm{Ca}, \mathrm{Mg}$, and $\mathrm{Ni}$, also being leachable. Very little $\mathrm{Al}$ or Fe were water leachable from the sludge. The primary soluble metals in the $\mathrm{Ca}(\mathrm{OH})_{2}$ leach tests were $\mathrm{Al}$ and Na with no detectable Mn. The only soluble metal seen in the $\mathrm{CaCO}_{3}$ tests was $\mathrm{Na}$. (Note that the concentrations measured in the water leachates are the sums of the water-leachable amounts and the initial dissolved pore water concentrations.)

\subsubsection{Anion Concentrations - Single Contact Batch Test}

The anion concentrations in single contact batch test from the tank C-106 sludge samples are listed in Table 4.5. The primary leachable anion for the water leach test was oxalate, with much smaller quantities of leachable chloride. There were no detectable anions in the $\mathrm{Ca}(\mathrm{OH})_{2}$ or the $\mathrm{CaCO}_{3}$ leached samples; however, the detection limit for carbonate was high at $61,200 \mu \mathrm{g} / \mathrm{g}$. The presence of high concentrations of oxalate (33,900 to $41,600 \mu \mathrm{g} / \mathrm{g})$ in the water extracts shows that the sludge has the capacity to act as a reductant for more oxidized species. However, its presence in the sludge in contact with air suggests the oxalate is not readily oxidized in this environment.

\subsubsection{Radioanalytical Results - Single Contact Batch Test}

The results of the GEA analysis for ${ }^{137} \mathrm{Cs}$ in the single contact batch test are listed in Table 4.6. For the tank C-106 sludge samples, ${ }^{137} \mathrm{Cs}$ was not analyzed in the 1-month water leachates, but was measured at values of 2.03 and $2.65 \mu \mathrm{g} / \mathrm{g}$ in the 1-day water leach. The leachable concentrations of ${ }^{137} \mathrm{Cs}$ were measured in the range of 0.095 to $0.138 \mu \mathrm{g} / \mathrm{g}$ for the $\mathrm{Ca}(\mathrm{OH})_{2}$ and the $\mathrm{CaCO}_{3}$ leaches.

Table 4.7 lists the leachable concentrations of ${ }^{90} \mathrm{Sr},{ }^{239} \mathrm{Pu},{ }^{237} \mathrm{~Np}$, and ${ }^{241} \mathrm{Am}$ in terms of the original sludge compositions. The ${ }^{90} \mathrm{Sr}$ concentration was not measured in the 1-month water extract but ranged from 0.310 to $0.697 \mu \mathrm{g} / \mathrm{g}$ in the 1-day water leach. The amounts measured in the simulated cement leach ranged from 0.049 to $0.146 \mu \mathrm{g} / \mathrm{g}$ for the $\mathrm{Ca}(\mathrm{OH})_{2}$ leachates and 0.022 to $0.517 \mu \mathrm{g} / \mathrm{g}$ for the $\mathrm{CaCO}_{3}$ leachates. Leachable quantities of ${ }^{237} \mathrm{~Np}(0.651$ to $0.985 \mu \mathrm{g} / \mathrm{g})$ and ${ }^{241} \mathrm{Am}(0.0016$ to $0.0029 \mu \mathrm{g} / \mathrm{g})$ were measured in the water leach samples, but no detectable ${ }^{239} \mathrm{Pu}$ was found. ${ }^{237} \mathrm{~Np},{ }^{239} \mathrm{Pu}$, and ${ }^{241} \mathrm{Am}$ were not detected in any of the $\mathrm{Ca}(\mathrm{OH})_{2}$ and $\mathrm{CaCO}_{3}$ leachates.

\subsubsection{Sequential Contact Leaching Test}

The sequential contact leaching tests were conducted by contacting each sludge sample with sequential 30-mL quantities of fresh leach solutions consisting of DDI water, $\mathrm{Ca}(\mathrm{OH})_{2}$ and $\mathrm{CaCO}_{3}$. As shown in Table 4.8, the sludge was contacted six times with each solution. The first five contacts were of short duration ( 1 or 4 days each), which was assumed sufficient for leaching contaminants of concern from the sludge. To test this assumption, an extended period of leaching was conducted in which the sludge, after the first five stages of leaching, was contacted for 43 days (Stage 6). The objective of this state was to evaluate the long-term leaching characteristics of contaminants from the sludge. Very little of the primary contaminants of concern, ${ }^{99} \mathrm{Tc},{ }^{238} \mathrm{U}$, and ${ }^{129} \mathrm{I}$ was leachable during these tests. Over $90 \%$ of the ${ }^{99} \mathrm{Tc},{ }^{238} \mathrm{U}$, and ${ }^{129} \mathrm{I}$ remained in the sludge and was not leachable during the six stages of leaching with the three solutions. 
Table 4.4. Leachable Metal Concentrations in Single Contact Batch Test

\begin{tabular}{|c|c|c|c|c|c|c|c|c|c|c|}
\hline Sample Number & $\begin{array}{c}\mathrm{Al} \\
(\mu \mathrm{g} / \mathrm{g})\end{array}$ & $\begin{array}{c}\text { Ва } \\
(\mu \mathrm{g} / \mathrm{g})\end{array}$ & $\begin{array}{c}\text { Ca } \\
(\mu \mathrm{g} / \mathrm{g})\end{array}$ & $\begin{array}{c}\mathrm{Cr} \\
(\mu \mathrm{g} / \mathrm{g})\end{array}$ & $\begin{array}{c}\mathrm{Fe} \\
(\mu \mathrm{g} / \mathrm{g})\end{array}$ & $\begin{array}{c}\mathrm{K} \\
(\mu \mathrm{g} / \mathrm{g})\end{array}$ & $\begin{array}{c}\mathrm{Mg} \\
(\mu \mathrm{g} / \mathrm{g})\end{array}$ & $\begin{array}{c}\mathrm{Mn} \\
(\mu \mathrm{g} / \mathrm{g})\end{array}$ & $\begin{array}{c}\mathrm{Ni} \\
(\mu \mathrm{g} / \mathrm{g})\end{array}$ & $\begin{array}{c}\mathrm{Na} \\
(\mu \mathrm{g} / \mathrm{g})\end{array}$ \\
\hline $\begin{array}{l}\text { C-106 Water Leach } \\
\text { Range, } 1 \text { month }\end{array}$ & $<2.61 \mathrm{E}+01$ & $\begin{array}{c}1.26 \mathrm{E}+01 \text { to } \\
2.64 \mathrm{E}+01\end{array}$ & $\begin{array}{c}5.98 \mathrm{E}+01 \text { to } \\
1.26 \mathrm{E}+02\end{array}$ & $\begin{array}{c}2.28 \mathrm{E}+00 \text { to } \\
3.90 \mathrm{E}+00\end{array}$ & $<1.05 \mathrm{E}+01$ & $<2.61 \mathrm{E}+02$ & $\begin{array}{l}1.62 \mathrm{E}+02 \text { to } \\
2.32 \mathrm{E}+02\end{array}$ & $\begin{array}{c}7.66 \mathrm{E}+03 \text { to } \\
1.39 \mathrm{E}+04\end{array}$ & $\begin{array}{c}8.90 \mathrm{E}+01 \text { to } \\
1.33 \mathrm{E}+02\end{array}$ & $\begin{array}{c}9.23 \mathrm{E}+03 \text { to } \\
1.06 \mathrm{E}+04\end{array}$ \\
\hline $\begin{array}{l}\mathrm{C}-106 \mathrm{Ca}(\mathrm{OH})_{2} \\
\text { Range, } 1 \text { month }\end{array}$ & $\begin{array}{c}8.67 \mathrm{E}+03 \text { to } \\
1.48 \mathrm{E}+04\end{array}$ & $<3.06 \mathrm{E}+02$ & $\begin{array}{c}(2.14 \mathrm{E}+02) \text { to } \\
3.88 \mathrm{E}+02 \\
\end{array}$ & $<1.54 \mathrm{E}+02$ & $<3.06 \mathrm{E}+02$ & $<7.65 \mathrm{E}+04$ & $<6.12 \mathrm{E}+02$ & $<3.06 \mathrm{E}+02$ & $<6.12 \mathrm{E}+02$ & $\begin{array}{c}1.99 \mathrm{E}+04 \text { to } \\
2.65 \mathrm{E}+04\end{array}$ \\
\hline $\begin{array}{l}\text { C-106 CaCO3 Range, } \\
1 \text { month }\end{array}$ & $<1.53 \mathrm{E}+03$ & $<3.06 \mathrm{E}+02$ & $\begin{array}{c}8.26 \mathrm{E}+02 \text { to } \\
1.45 \mathrm{E}+04\end{array}$ & $<1.54 \mathrm{E}+02$ & $<3.06 \mathrm{E}+02$ & $<7.65 \mathrm{E}+04$ & $<6.12 \mathrm{E}+02$ & $<3.06 \mathrm{E}+02$ & $<6.12 \mathrm{E}+02$ & $\begin{array}{c}4.73 \mathrm{E}+03 \text { to } \\
6.29 \mathrm{E}+03\end{array}$ \\
\hline
\end{tabular}

Table 4.5. Average Anion Concentrations Leached During Single Contact Batch Test

\begin{tabular}{||l|c|c|c|c|c|c|c|c|c||}
\hline \hline & $\begin{array}{c}\text { Fluoride } \\
(\mu \mathrm{g} / \mathrm{g})\end{array}$ & $\begin{array}{c}\text { Chloride } \\
(\mu \mathrm{g} / \mathrm{g})\end{array}$ & $\begin{array}{c}\text { Nitrite } \\
(\mu \mathrm{g} / \mathrm{g})\end{array}$ & $\begin{array}{c}\text { Bromide } \\
(\mu \mathrm{g} / \mathrm{g})\end{array}$ & $\begin{array}{c}\text { Nitrate } \\
(\mu \mathrm{g} / \mathrm{g})\end{array}$ & $\begin{array}{c}\text { Carbonate } \\
(\mu \mathrm{g} / \mathrm{g})\end{array}$ & $\begin{array}{c}\text { Sulfate } \\
(\mu \mathrm{g} / \mathrm{g})\end{array}$ & $\begin{array}{c}\text { Oxalate* } \\
(\mu \mathrm{g} / \mathrm{g})\end{array}$ & $\begin{array}{c}\text { Phosphate } \\
(\mu \mathrm{g} / \mathrm{g})\end{array}$ \\
\hline \begin{tabular}{|l}
$\mathrm{C}-106$ Water Leach \\
Range, 1 month
\end{tabular} & $<2.14 \mathrm{E}+02$ & $\begin{array}{c}2.60 \mathrm{E}+2 \text { to } \\
7.77 \mathrm{E}+02\end{array}$ & $<7.86 \mathrm{E}+02$ & $<8.38 \mathrm{E}+02$ & $<7.53 \mathrm{E}+02$ & $<8.71 \mathrm{E}+04$ & $<7.13 \mathrm{E}+02$ & $\begin{array}{c}3.39 \mathrm{E}+04 \text { to } \\
4.16 \mathrm{E}+04\end{array}$ & $<1.06 \mathrm{E}+00$ \\
\hline $\begin{array}{l}\mathrm{C}-106 \mathrm{Ca}(\mathrm{OH})_{2} \text { Range, } \\
1 \text { month }\end{array}$ & $<1.43 \mathrm{E}+02$ & $<2.89 \mathrm{E}+02$ & $<5.52 \mathrm{E}+02$ & $<5.88 \mathrm{E}+02$ & $<5.30 \mathrm{E}+02$ & $<6.12 \mathrm{E}+04$ & $<5.00 \mathrm{E}+02$ & $<2.18 \mathrm{E}+03$ & $<6.18 \mathrm{E}+02$ \\
\hline $\begin{array}{l}\text { C-106 CaCO3 Range, } \\
1 \text { month }\end{array}$ & $<1.43 \mathrm{E}+02$ & $<2.88 \mathrm{E}+02$ & $<5.52 \mathrm{E}+02$ & $<5.88 \mathrm{E}+02$ & $<5.30 \mathrm{E}+02$ & $<6.12 \mathrm{E}+04$ & $<5.01 \mathrm{E}+02$ & $<4.22 \mathrm{E}+02$ & $<6.18 \mathrm{E}+02$ \\
\hline
\end{tabular}


Table 4.6. ${ }^{137}$ Cs Leached During Single Contact Batch Test

\begin{tabular}{||l|c|c||}
\hline \hline & $\begin{array}{c}{ }^{137} \mathrm{Cs} \\
(\mu \mathrm{Ci} / \mathrm{g})\end{array}$ & $\begin{array}{c}{ }^{137} \mathrm{Cs} \\
(\mu \mathrm{g} / \mathrm{g})\end{array}$ \\
\hline \hline C-106 Water Leach Range, 1 day & $1.76 \mathrm{E}+02$ to $2.31 \mathrm{E}+02$ & 2.03 to 2.65 \\
\hline C-106 Ca(OH $)_{2}$ Range, 1 month & $8.50 \mathrm{E}+00$ to $1.20 \mathrm{E}+01$ & $9.77 \mathrm{E}-02$ to $1.38 \mathrm{E}-01$ \\
\hline C-106 $\mathrm{CaCO}_{3}$ Range, 1 month & $8.25 \mathrm{E}+00$ to $1.11 \mathrm{E}+01$ & $9.48 \mathrm{E}-02$ to $1.28 \mathrm{E}-01$ \\
\hline
\end{tabular}

Table 4.7. ${ }^{90} \mathrm{Sr}$ and Actinides Leached During Single Contact Batch Test

\begin{tabular}{||l|c|c|c|c|c|c|c|c||}
\hline \hline & $\begin{array}{c}{ }^{90} \mathrm{Sr} \\
(\mu \mathrm{Ci} / \mathrm{g})\end{array}$ & $\begin{array}{c}{ }^{90} 90 \\
(\mu \mathrm{g} / \mathrm{g})\end{array}$ & $\begin{array}{c}{ }^{239} \mathrm{Pu} \\
(\mu \mathrm{Ci} / \mathrm{g})\end{array}$ & $\begin{array}{c}{ }^{239} \mathrm{Pu} \\
(\mu \mathrm{g} / \mathrm{g})\end{array}$ & $\begin{array}{c}{ }^{237} \mathrm{~Np} \\
(\mu \mathrm{Ci} / \mathrm{g})\end{array}$ & $\begin{array}{c}{ }^{237} \mathrm{~Np} \\
(\mu \mathrm{g} / \mathrm{g})\end{array}$ & $\begin{array}{c}{ }^{241} \mathrm{Am} \\
(\mu \mathrm{Ci} / \mathrm{g})\end{array}$ & $\begin{array}{c}{ }^{241} \mathrm{Am} \\
(\mu \mathrm{g} / \mathrm{g})\end{array}$ \\
\hline \hline C-106 Water Leach \\
Range, 1 month
\end{tabular}

Table 4.8. Contact Times, $\mathrm{pH}$ Range, and Alkalinities for Sequential Contact Leaching Test on Tank C-106 Sludge Samples

\begin{tabular}{|c|c|c|c|c|}
\hline $\begin{array}{l}\text { Contact } \\
\text { Stage }\end{array}$ & $\begin{array}{l}\text { Contact Duration } \\
\text { (Days) }\end{array}$ & Extractants & $\mathrm{pH}$ & $\begin{array}{c}\text { Akalinity as } \\
\mathrm{CaCO}_{3}(\mathrm{mg} / \mathrm{g})\end{array}$ \\
\hline \multirow[t]{4}{*}{1} & 1 & & & \\
\hline & & C-106 Water & 6.72 to 7.06 & 37.6 to 64.7 \\
\hline & & $\mathrm{C}-106 \mathrm{Ca}(\mathrm{OH})_{2}$ & 11.43 to 12.30 & 388 to 844 \\
\hline & & $\mathrm{C}-106 \mathrm{CaCO}_{3}$ & 11.45 to 11.54 & 377 to 442 \\
\hline \multirow[t]{4}{*}{2} & 1 & & & \\
\hline & & C-106 Water & 6.80 to 6.94 & $<55$ \\
\hline & & $\mathrm{C}-106 \mathrm{Ca}(\mathrm{OH})_{2}$ & 12.24 to 12.49 & 280 to 804 \\
\hline & & $\mathrm{C}-106 \mathrm{CaCO}_{3}$ & 11.30 to 11.51 & 377 to 529 \\
\hline \multirow[t]{4}{*}{3} & 4 & & & \\
\hline & & C-106 Water & 6.77 to 7.02 & $<55$ \\
\hline & & $\mathrm{C}-106 \mathrm{Ca}(\mathrm{OH})_{2}$ & 12.38 to 12.62 & 331 to 719 \\
\hline & & $\mathrm{C}-106 \mathrm{CaCO}_{3}$ & 11.38 to 11.55 & 388 to 681 \\
\hline \multirow[t]{4}{*}{4} & 1 & & & \\
\hline & & C-106 Water & 6.67 to 6.77 & $<55$ \\
\hline & & $\mathrm{C}-106 \mathrm{Ca}(\mathrm{OH})_{2}$ & 12.14 to 12.50 & 377 to 641 \\
\hline & & $\mathrm{C}-106 \mathrm{CaCO}_{3}$ & 11.39 to 11.45 & 396 to 445 \\
\hline \multirow[t]{4}{*}{5} & 1 & & & \\
\hline & & C-106 Water & 6.68 to 6.74 & $<55$ \\
\hline & & $\mathrm{C}-106 \mathrm{Ca}(\mathrm{OH})_{2}$ & 12.44 to 12.58 & 321 to 685 \\
\hline & & $\mathrm{C}-106 \mathrm{CaCO}_{3}$ & 11.14 to 11.40 & 331 to 442 \\
\hline \multirow[t]{4}{*}{6} & 43 & & & \\
\hline & & C-106 Water & 7.47 & 13.7 \\
\hline & & $\mathrm{C}-106 \mathrm{Ca}(\mathrm{OH})_{2}$ & 11.98 to 12.23 & 388 to 709 \\
\hline & & $\mathrm{C}-106 \mathrm{CaCO}_{3}$ & 11.54 to 11.75 & 396 to 520 \\
\hline
\end{tabular}




\subsubsection{Digestion Factors and Moisture Contents - Sequential Contact Leaching Test}

The digestion factors for the C-106 sludge samples used for the sequential contact leaching tests varied from $4.5 \mathrm{~g} / \mathrm{L}$ to $10.7 \mathrm{~g} / \mathrm{L}$. These digestion factors are the ratios of wet weight of sludge to the amount of extractant $(30 \mathrm{~mL}$ ) used to dissolve the soluble portion of the solid. The digestion factors were then multiplied by the percent solids, as determined from moisture content analysis, to convert concentrations to a dry weight basis. The variability in digestion factors is a function of the mass of sludge used, which ranged from approximately 0.2 to $0.35 \mathrm{~g}$.

The moisture contents [(wet wt - dry wt)/dry wt] averaged about 50.5\% for the C-106 samples used in the DDI water extraction and $12.1 \%$ for the samples used in the $\mathrm{Ca}(\mathrm{OH})_{2}$ and the $\mathrm{CaCO}_{3}$ leaches.

\subsubsection{2 $\quad \mathrm{pH}$ and Alkalinity - Sequential Contact Leaching Test}

Table 4.8 lists the $\mathrm{pH}$ values and alkalinities for the leachates from the sequential contact leaching tests. The water leachate $\mathrm{pH}$ values for the first five stages were in the range 6.87 to 7.03 and then increased to an average of 7.5 in Stage 6. The increase in $\mathrm{pH}$ at Stage 6 may reflect equilibration with a carbonate mineral. The average $\mathrm{pH}$ value of 12.3 for the $\mathrm{Ca}(\mathrm{OH})_{2}$ leachates corresponds to the $\mathrm{pH}$ of the $\mathrm{Ca}(\mathrm{OH})_{2}$-saturated solution used as the leachant. This suggests that the $\mathrm{pH}$ is controlled by the solution with no noticeable effect from the sludge. The average $\mathrm{pH}$ of 11.5 for the $\mathrm{CaCO}_{3}$ solution was higher than the expected $\mathrm{pH}$ of 8.3, which suggests that the sludge and its pore water controls the $\mathrm{pH}$ during this portion of the leaching tests. There were measurable alkalinity values only in the first stage of the water extract (37.6 to $64.7 \mathrm{mg} \mathrm{CaCO} 3$ per gram) and the sixth stage (average value of $13.2 \mathrm{mg} \mathrm{CaCO}_{3}$ per gram). The average alkalinity values for the simulated cement leaches were $524 \mathrm{mg} \mathrm{CaCO}_{3}$ per gram sludge for the $\mathrm{Ca}(\mathrm{OH})_{2}$ leaches and $449 \mathrm{mg} \mathrm{CaCO}_{3}$ per gram sludge for the $\mathrm{CaCO}_{3}$ leaches.

\subsubsection{3 $\quad{ }^{99} \mathrm{Tc},{ }^{238} \mathrm{U}$, and ${ }^{129} \mathrm{I}$ - Sequential Contact Leaching Test}

Table 4.9 lists the amount of ${ }^{99} \mathrm{Tc},{ }^{238} \mathrm{U}$, and ${ }^{129} \mathrm{I}$ leached from the sludge samples during the sequential contact leaching tests, and Table 4.10 lists the percentages of the available radionuclides that were leached. As was found in the single-contact water leach tests (Table 4.3), very little of the ${ }^{99} \mathrm{Tc}$, ${ }^{238} \mathrm{U}$, or ${ }^{129} \mathrm{I}$ was leachable. Only $1.3 \%$ to $2.0 \%$ of the ${ }^{99} \mathrm{Tc}$ was water leachable, whereas $5.2 \%$ to $6.3 \%$ was leachable with the $\mathrm{Ca}(\mathrm{OH})_{2}$ solution. Approximately $4 \%$ of the ${ }^{238} \mathrm{U}$ was water leachable throughout the six contact stages and $<1.0 \%$ was leached by the $\mathrm{Ca}(\mathrm{OH})_{2}$ and $\mathrm{CaCO}_{3}$ solutions. There was no detectable ${ }^{129} \mathrm{I}$ in any of the leaching solutions. These results show the recalcitrant nature of the residual ${ }^{99} \mathrm{Tc},{ }^{238} \mathrm{U}$, and ${ }^{129} \mathrm{I}$ in the sludge in tank C-106 after the oxalic acid sluicing campaign.

\subsubsection{Selected Metals Concentrations - Sequential Contact Leaching Test}

Table 4.11 lists the concentration of metals leached during the sequential contact leaching tests. $\mathrm{Al}$ is leachable in the sludge samples during the majority of the water-leach and $\mathrm{CaCO}_{3}$-leach stages, whereas it is not leachable (at a detection limit of $1.37 \mathrm{E}+03 \mu \mathrm{g} / \mathrm{g}$ ) in most of the $\mathrm{Ca}(\mathrm{OH})_{2}$ leach stages. $\mathrm{Na}$ is leachable during all of the water-leach and $\mathrm{Ca}(\mathrm{OH})_{2}$-leach stages, but is not apparently leachable (at a detection limit of $2.46 \mathrm{E}+03 \mu \mathrm{g} / \mathrm{g}$ ) during the $\mathrm{CaCO}_{3}$-leach stages. Because the $\mathrm{CaCO}_{3}$ leaches were conducted after the $\mathrm{Ca}(\mathrm{OH})_{2}$ leaches on the same sludge samples, this may be due to removal of the majority of the leachable Na during the $\mathrm{Ca}(\mathrm{OH})_{2}$ leaches rather than a change in geochemical conditions that made the Na less mobile. 
Table 4.9. ${ }^{99} \mathrm{Tc}$ and ${ }^{238} \mathrm{U}$ Concentrations Leached During Sequential Contact Test

\begin{tabular}{|c|c|c|c|c|c|c|}
\hline & $\begin{array}{c}{ }^{99} \mathrm{Tc} \\
(\mu \mathrm{Ci} / \mathrm{g}) \\
\end{array}$ & $\begin{array}{c}{ }^{99} \mathrm{Tc} \\
(\mu \mathrm{g} / \mathrm{g})\end{array}$ & $\begin{array}{c}{ }^{238} \mathrm{U} \\
(\mu \mathrm{Ci} / \mathrm{g}) \\
\end{array}$ & $\begin{array}{c}{ }^{238} \mathrm{U} \\
(\mu \mathrm{g} / \mathrm{g}) \\
\end{array}$ & $\begin{array}{c}{ }^{129} \mathrm{I} \\
(\mu \mathrm{Ci} / \mathrm{g}) \\
\end{array}$ & $\begin{array}{c}{ }^{129} \mathrm{I} \\
(\mu \mathrm{g} / \mathrm{g}) \\
\end{array}$ \\
\hline \multicolumn{7}{|l|}{ Stage 1} \\
\hline C-106 Water Leach & $\begin{array}{c}2.20 \mathrm{E}-04 \text { to } \\
3.47 \mathrm{E}-04 \\
\end{array}$ & $\begin{array}{c}1.29 \mathrm{E}-02 \text { to } \\
2.04 \mathrm{E}-02 \\
\end{array}$ & $\begin{array}{c}2.25 \mathrm{E}-06 \text { to } \\
2.70 \mathrm{E}-06 \\
\end{array}$ & $\begin{array}{c}6.62 \mathrm{E}+00 \text { to } \\
7.95 \mathrm{E}+00\end{array}$ & $<9.76 \mathrm{E}-06$ & $<5.53 \mathrm{E}-02$ \\
\hline $\mathrm{C}-106 \mathrm{Ca}(\mathrm{OH})_{2}$ & $\begin{array}{c}1.09 \mathrm{E}-03 \text { to } \\
1.39 \mathrm{E}-03\end{array}$ & $\begin{array}{c}6.41 \mathrm{E}-2 \text { to } \\
8.16 \mathrm{E}-02\end{array}$ & $<2.19 \mathrm{E}-08$ & $<6.45 \mathrm{E}-02$ & $<2.28 \mathrm{E}-05$ & $<1.29 \mathrm{E}-01$ \\
\hline $\mathrm{C}-106 \mathrm{CaCO}_{3}$ & $<9.33 \mathrm{E}-02$ & $<5.49 \mathrm{E}+00$ & $\begin{array}{c}1.67 \mathrm{E}-08 \text { to } \\
3.34 \mathrm{E}-08\end{array}$ & $\begin{array}{c}\text { 7.33E-02 to } \\
9.83 \mathrm{E}-02\end{array}$ & $<9.67 \mathrm{E}-05$ & $<5.47 \mathrm{E}-01$ \\
\hline \multicolumn{7}{|l|}{ Stage 2} \\
\hline C-106 Water Leach & $<9.98 \mathrm{E}-05$ & $<5.87 \mathrm{E}-03$ & $\begin{array}{c}4.40 \mathrm{E}-07 \text { to } \\
5.76 \mathrm{E}-07\end{array}$ & $\begin{array}{c}1.30 \mathrm{E}+00 \text { to } \\
1.69 \mathrm{E}+00\end{array}$ & NA & NA \\
\hline $\mathrm{C}-106 \mathrm{Ca}(\mathrm{OH})_{2}$ & $<1.10 \mathrm{E}-03$ & $<6.45 \mathrm{E}-02$ & $\begin{array}{c}3.98 \mathrm{E}-8 \text { to } \\
8.21 \mathrm{E}-08\end{array}$ & $\begin{array}{c}1.17 \mathrm{E}-01 \text { to } \\
2.41 \mathrm{E}-01\end{array}$ & $<2.28 \mathrm{E}-05$ & $<1.29 \mathrm{E}-01$ \\
\hline $\mathrm{C}-106 \mathrm{CaCO}_{3}$ & $<9.33 \mathrm{E}-02$ & $<5.49 \mathrm{E}+00$ & $\begin{array}{c}2.80 \mathrm{E}-08 \text { to } \\
3.12 \mathrm{E}-08\end{array}$ & $\begin{array}{c}6.24 \mathrm{E}-02 \text { to } \\
9.17 \mathrm{E}-02\end{array}$ & $<9.67 \mathrm{E}-05$ & $<5.47 \mathrm{E}-01$ \\
\hline \multicolumn{7}{|l|}{ Stage 3} \\
\hline C-106 Water Leach & $<1.13 \mathrm{E}-04$ & $<6.63 \mathrm{E}-03$ & $\begin{array}{c}1.87 \mathrm{E}-07 \text { to } \\
2.33 \mathrm{E}-07 \\
\end{array}$ & $\begin{array}{c}5.51 \mathrm{E}-01 \text { to } \\
6.85 \mathrm{E}-01 \\
\end{array}$ & NA & NA \\
\hline $\mathrm{C}-106 \mathrm{Ca}(\mathrm{OH})_{2}$ & $<1.10 \mathrm{E}-03$ & $<6.45 \mathrm{E}-02$ & $\begin{array}{c}3.75 \mathrm{E}-08 \text { to } \\
7.11 \mathrm{E}-08\end{array}$ & $\begin{array}{c}1.10 \mathrm{E}-01 \text { to } \\
2.09 \mathrm{E}-01\end{array}$ & $<2.28 \mathrm{E}-05$ & $<1.29 \mathrm{E}-01$ \\
\hline $\mathrm{C}-106 \mathrm{CaCO}_{3}$ & $<9.33 \mathrm{E}-02$ & $<5.49 \mathrm{E}+00$ & $\begin{array}{c}1.67 \mathrm{E}-08 \text { to } \\
3.87 \mathrm{E}-08\end{array}$ & $\begin{array}{c}9.47 \mathrm{E}-2 \text { to } \\
1.14 \mathrm{E}-01\end{array}$ & $<9.67 \mathrm{E}-05$ & $<5.47 \mathrm{E}-01$ \\
\hline \multicolumn{7}{|l|}{ Stage 4} \\
\hline C-106 Water Leach & $<1.13 \mathrm{E}-04$ & $<6.63 \mathrm{E}-03$ & $\begin{array}{c}\text { 6.07E-08 to } \\
9.12 \mathrm{E}-08\end{array}$ & $\begin{array}{c}1.78 \mathrm{E}-01 \text { to } \\
2.68 \mathrm{E}-01\end{array}$ & NA & NA \\
\hline $\mathrm{C}-106 \mathrm{Ca}(\mathrm{OH})_{2}$ & $<1.10 \mathrm{E}-03$ & $<6.45 \mathrm{E}-02$ & $\begin{array}{c}3.12 \mathrm{E}-08 \text { to } \\
5.84 \mathrm{E}-08\end{array}$ & $\begin{array}{c}1.13 \mathrm{E}-01 \text { to } \\
1.81 \mathrm{E}-01\end{array}$ & $<2.28 \mathrm{E}-05$ & $<1.29 \mathrm{E}-01$ \\
\hline $\mathrm{C}-106 \mathrm{CaCO}_{3}$ & $<9.33 \mathrm{E}-02$ & $<5.49 \mathrm{E}+00$ & $\begin{array}{c}3.47 \mathrm{E}-08 \text { to } \\
4.24 \mathrm{E}-08\end{array}$ & $\begin{array}{c}9.42 \mathrm{E}-02 \text { to } \\
1.25 \mathrm{E}-04\end{array}$ & $<9.67 \mathrm{E}-05$ & $<5.47 \mathrm{E}-01$ \\
\hline \multicolumn{7}{|l|}{ Stage 5} \\
\hline C-106 Water Leach & $<1.13 \mathrm{E}-04$ & $<6.63 \mathrm{E}-03$ & $\begin{array}{c}2.87 \mathrm{E}-08 \text { to } \\
3.41 \mathrm{E}-08\end{array}$ & $\begin{array}{c}8.45 \mathrm{E}-02 \text { to } \\
1.00 \mathrm{E}-01\end{array}$ & NA & NA \\
\hline $\mathrm{C}-106 \mathrm{Ca}(\mathrm{OH})_{2}$ & $<1.10 \mathrm{E}-03$ & $<6.45 \mathrm{E}-02$ & $\begin{array}{c}2.72 \mathrm{E}-08 \text { to } \\
7.58 \mathrm{E}-08\end{array}$ & $\begin{array}{c}8.01 \mathrm{E}-02 \text { to } \\
2.23 \mathrm{E}-01\end{array}$ & $<2.28 \mathrm{E}-05$ & $<1.29 \mathrm{E}-01$ \\
\hline $\mathrm{C}-106 \mathrm{CaCO}_{3}$ & $<9.33 \mathrm{E}-02$ & $<5.49 \mathrm{E}+00$ & $\begin{array}{c}1.87 \mathrm{E}-08 \text { to } \\
4.35 \mathrm{E}-08\end{array}$ & $\begin{array}{c}8.45 \mathrm{E}-02 \text { to } \\
1.28 \mathrm{E}-01 \\
\end{array}$ & $<9.67 \mathrm{E}-05$ & $<5.47 \mathrm{E}-01$ \\
\hline \multicolumn{7}{|l|}{ Stage 6} \\
\hline C-106 Water Leach & 6.15E-04 & 3.62E-02 & 7.63E-08 & 2.25E-01 & 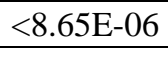 & $<4.89 \mathrm{E}-02$ \\
\hline $\mathrm{C}-106 \mathrm{Ca}(\mathrm{OH})_{2}$ & $\begin{array}{c}1.28 \mathrm{E}-03 \text { to } \\
2.39 \mathrm{E}-03\end{array}$ & $\begin{array}{c}7.55 \mathrm{E}-02 \text { to } \\
1.41 \mathrm{E}-01 \\
\end{array}$ & $\begin{array}{c}1.90 \mathrm{E}-08 \text { to } \\
3.02 \mathrm{E}-08\end{array}$ & $\begin{array}{c}5.59 \mathrm{E}-02 \text { to } \\
8.89 \mathrm{E}-02 \\
\end{array}$ & $<2.28 \mathrm{E}-05$ & $<1.29 \mathrm{E}-01$ \\
\hline $\mathrm{C}-106 \mathrm{CaCO}_{3}$ & $<9.33 \mathrm{E}-02$ & $<5.49 \mathrm{E}+00$ & $\begin{array}{c}3.21 \mathrm{E}-08 \text { to } \\
3.87 \mathrm{E}-08\end{array}$ & $\begin{array}{c}9.43 \mathrm{E}-02 \text { to } \\
1.14 \mathrm{E}-01\end{array}$ & $<9.67 \mathrm{E}-05$ & $<5.47 \mathrm{E}-01$ \\
\hline
\end{tabular}


Table 4.10. Water-Leachable Percentages of ${ }^{99} \mathrm{Tc},{ }^{238} \mathrm{U}$, and ${ }^{129} \mathrm{I}$ in Tank C-106 Sludge Sequential Contact Leaching Test Relative to Fusion Results

\begin{tabular}{|c|c|c|c|}
\hline & ${ }^{999} \mathrm{Tc}$ & ${ }^{238} \mathrm{U}$ & $\overline{{ }^{129} \mathrm{I}}$ \\
\hline & \multicolumn{3}{|c|}{ (\% Leachable) } \\
\hline \multicolumn{4}{|l|}{ Stage 1} \\
\hline C-106 Water Leach & 1.3 to 2.0 & 2.8 to 3.4 & $<1.4$ \\
\hline $\mathrm{C}-106 \mathrm{Ca}(\mathrm{OH})_{2}$ & 5.2 to 6.3 & 0.3 & $<3.2$ \\
\hline $\mathrm{C}-106 \mathrm{CaCO}_{3}$ & ND & 0.02 to 0.04 & $<13.6$ \\
\hline \multicolumn{4}{|l|}{ Stage 2} \\
\hline C-106 Water Leach & $<0.58$ & 0.5 to 0.7 & NA \\
\hline $\mathrm{C}-106 \mathrm{Ca}(\mathrm{OH})_{2}$ & $<6.4$ & 0.02 to 0.1 & $<3.2$ \\
\hline $\mathrm{C}-106 \mathrm{CaCO}_{3}$ & ND & 0.03 to 0.04 & $<13.6$ \\
\hline \multicolumn{4}{|l|}{ Stage 3} \\
\hline |C-106 Water Leach & $<0.58$ & 0.2 to 0.3 & NA \\
\hline $\mathrm{C}-106 \mathrm{Ca}(\mathrm{OH})_{2}$ & $<6.4$ & 0.06 to 0.09 & $<3.2$ \\
\hline $\mathrm{C}-106 \mathrm{CaCO}_{3}$ & ND & 0.02 to 0.05 & $<13.6$ \\
\hline \multicolumn{4}{|l|}{ Stage 4} \\
\hline C-106 Water Leach & $<0.58$ & 0.08 to 0.11 & NA \\
\hline $\mathrm{C}-106 \mathrm{Ca}(\mathrm{OH})_{2}$ & $<6.4$ & 0.05 to 0.09 & $<3.2$ \\
\hline $\mathrm{C}-106 \mathrm{CaCO}_{3}$ & ND & 0.04 to 0.05 & $<13.6$ \\
\hline \multicolumn{4}{|l|}{ Stage 5} \\
\hline C-106 Water Leach & $<0.58$ & 0.03 to 0.04 & NA \\
\hline $\mathrm{C}-106 \mathrm{Ca}(\mathrm{OH})_{2}$ & $<6.4$ & 0.02 to 0.08 & $<3.2$ \\
\hline $\mathrm{C}-106 \mathrm{CaCO}_{3}$ & ND & 0.02 to 0.05 & $<13.6$ \\
\hline \multicolumn{4}{|l|}{ Stage 6} \\
\hline C-106 Water Leach & $<0.58$ & 0.09 to 0.10 & NA \\
\hline $\mathrm{C}-106 \mathrm{Ca}(\mathrm{OH})_{2}$ & $<6.4$ & 0.02 to 0.04 & $<3.2$ \\
\hline $\mathrm{C}-106 \mathrm{CaCO}_{3}$ & ND & 0.04 to 0.05 & $<13.6$ \\
\hline
\end{tabular}

$\mathrm{Ba}, \mathrm{Mg}, \mathrm{Mn}$, and Ni only had detectable leachable concentrations during the water-leach stages. This may partially be due to the higher detection limits for $\mathrm{Ba}, \mathrm{Mg}$, and $\mathrm{Ni}$ during the $\mathrm{Ca}(\mathrm{OH})_{2}$ and $\mathrm{CaCO}_{3}$ leaches. The Mn detection limit for the $\mathrm{Ca}(\mathrm{OH})_{2}$ and $\mathrm{CaCO}_{3}$ leaches was lower than the water leaches; therefore, it appears that $\mathrm{Mn}$ was less leachable in the $\mathrm{Ca}(\mathrm{OH})_{2}$ and $\mathrm{CaCO}_{3}$ solutions. This may be due to the formation of Mn hydroxide or carbonate solids under the high $\mathrm{pH}$ conditions of these solutions. Ca was water leachable during all stages of the sequential extractions. The Ca concentrations for the $\mathrm{Ca}(\mathrm{OH})_{2}$ and $\mathrm{CaCO}_{3}$ leach tests reflect the $\mathrm{Ca}$ in the leaching solutions. $\mathrm{Cr}$, Fe, and $\mathrm{K}$ were not leachable with any of the leaching solutions. 
Table 4.11. Metals Concentrations Leached During Sequential Contact Tests

\begin{tabular}{|c|c|c|c|c|c|c|c|c|c|c|}
\hline & $\begin{array}{c}\mathrm{Al} \\
(\mu \mathrm{g} / \mathrm{g}) \\
\end{array}$ & $\begin{array}{c}\mathrm{Ba} \\
(\mu \mathrm{g} / \mathrm{g}) \\
\end{array}$ & $\begin{array}{c}\mathrm{Ca} \\
(\mu \mathrm{g} / \mathrm{g})\end{array}$ & $\begin{array}{c}\mathrm{Cr} \\
(\mu \mathrm{g} / \mathrm{g})\end{array}$ & $\begin{array}{c}\mathrm{Fe} \\
(\mu \mathrm{g} / \mathrm{g})\end{array}$ & $\begin{array}{c}\mathrm{K} \\
(\mu \mathrm{g} / \mathrm{g})\end{array}$ & $\begin{array}{c}\mathrm{Mg} \\
(\mu \mathrm{g} / \mathrm{g})\end{array}$ & $\begin{array}{c}\mathrm{Mn} \\
(\mu \mathrm{g} / \mathrm{g})\end{array}$ & $\begin{array}{c}\mathrm{Ni} \\
(\mu \mathrm{g} / \mathrm{g})\end{array}$ & $\begin{array}{c}\mathrm{Na} \\
(\mu \mathrm{g} / \mathrm{g})\end{array}$ \\
\hline \multicolumn{11}{|l|}{ Stage 1} \\
\hline C-106 Water Leach & $\begin{array}{c}81.9 \mathrm{E}+01 \text { to } \\
1.38 \mathrm{E}+02\end{array}$ & $\begin{array}{c}3.83 \mathrm{E}+01 \text { to } \\
1.02 \mathrm{E}+02\end{array}$ & $\begin{array}{c}2.91 \mathrm{E}+02 \\
\text { to } \\
9.73 \mathrm{E}+02\end{array}$ & $<6.12 \mathrm{E}+01$ & $<1.11 \mathrm{E}+02$ & $<1.39 \mathrm{E}+03$ & $\begin{array}{c}1.61 \mathrm{E}+02 \text { to } \\
2.91 \mathrm{E}+02\end{array}$ & $\begin{array}{c}9.65 \mathrm{E}+03 \text { to } \\
1.64 \mathrm{E}+04\end{array}$ & $\begin{array}{l}1.91 \mathrm{E}+02 \text { to } \\
3.29 \mathrm{E}+02\end{array}$ & $\begin{array}{c}9.50 \mathrm{E}+03 \text { to } \\
1.30 \mathrm{E}+04\end{array}$ \\
\hline $\mathrm{C}-106 \mathrm{Ca}(\mathrm{OH})_{2}$ & $\begin{array}{c}2.30 \mathrm{E}+03 \text { to } \\
4.98 \mathrm{E}+03\end{array}$ & $<2.74 \mathrm{E}+02$ & $\begin{array}{c}1.32 \mathrm{E}+03 \\
\text { to } \\
2.91 \mathrm{E}+04\end{array}$ & $<1.23 \mathrm{E}+02$ & $<2.74 \mathrm{E}+02$ & $<8.07 \mathrm{E}+04$ & $<5.47 \mathrm{E}+02$ & $<3.23 \mathrm{E}+02$ & $<5.47 \mathrm{E}+02$ & $\begin{array}{c}5.26 \mathrm{E}+03 \text { to } \\
1.39 \mathrm{E}+04\end{array}$ \\
\hline $\mathrm{C}-106 \mathrm{CaCO}_{3}$ & $\begin{array}{c}1.84 \mathrm{E}+03 \text { to } \\
3.58 \mathrm{E}+03\end{array}$ & $<2.74 \mathrm{E}+02$ & $\begin{array}{c}7.22 \mathrm{E}+03 \\
\text { to } \\
1.11 \mathrm{E}+04\end{array}$ & $<1.37 \mathrm{E}+02$ & $<2.74 \mathrm{E}+02$ & $<6.84 \mathrm{E}+04$ & $<5.49 \mathrm{E}+02$ & $<2.74 \mathrm{E}+02$ & $<5.49 \mathrm{E}+02$ & $<2.46 \mathrm{E}+03$ \\
\hline \multicolumn{11}{|l|}{ Stage 2} \\
\hline C-106 Water Leach & $\begin{array}{c}6.25 \mathrm{E}+01 \text { to } \\
1.22 \mathrm{E}+02\end{array}$ & $\begin{array}{c}3.03 \mathrm{E}+01 \text { to } \\
5.49 \mathrm{E}+01\end{array}$ & $\begin{array}{c}3.46 \mathrm{E}+02 \\
\text { to } \\
7.06 \mathrm{E}+02\end{array}$ & $<6.91 \mathrm{E}+01$ & $<1.11 \mathrm{E}+02$ & $<1.39 \mathrm{E}+03$ & $\begin{array}{c}1.45 \mathrm{E}+02 \text { to } \\
2.08 \mathrm{E}+02\end{array}$ & $\begin{array}{c}9.08 \mathrm{E}+03 \text { to } \\
1.20 \mathrm{E}+04\end{array}$ & $\begin{array}{c}1.66 \mathrm{E}+02 \text { to } \\
4.05 \mathrm{E}+02\end{array}$ & $\begin{array}{c}1.79 \mathrm{E}+03 \text { to } \\
2.45 \mathrm{E}+03\end{array}$ \\
\hline $\mathrm{C}-106 \mathrm{Ca}(\mathrm{OH})_{2}$ & $<1.37 \mathrm{E}+03$ & $<2.74 \mathrm{E}+02$ & $\begin{array}{c}1.88 \mathrm{E}+04 \\
\text { to } \\
5.83 \mathrm{E}+04\end{array}$ & $<1.37 \mathrm{E}+02$ & $<2.74 \mathrm{E}+02$ & $<8.07 \mathrm{E}+04$ & $<5.47 \mathrm{E}+02$ & $<3.23 \mathrm{E}+02$ & $<5.47 \mathrm{E}+02$ & $\begin{array}{c}6.34 \mathrm{E}+03 \text { to } \\
1.20 \mathrm{E}+04\end{array}$ \\
\hline $\mathrm{C}-106 \mathrm{CaCO}_{3}$ & $\begin{array}{c}2.49 \mathrm{E}+3 \text { to } \\
4.48 \mathrm{E}+03\end{array}$ & $<2.74 \mathrm{E}+02$ & $\begin{array}{c}1.10 \mathrm{E}+04 \\
\text { to } \\
1.31 \mathrm{E}+04\end{array}$ & $<1.37 \mathrm{E}+02$ & $<2.74 \mathrm{E}+02$ & $<6.84 \mathrm{E}+04$ & $<5.49 \mathrm{E}+02$ & $<2.74 \mathrm{E}+02$ & $<5.49 \mathrm{E}+02$ & $<2.46 \mathrm{E}+03$ \\
\hline \multicolumn{11}{|l|}{ Stage 3} \\
\hline C-106 Water Leach & $\begin{array}{c}6.66 \mathrm{E}+01 \text { to } \\
1.23 \mathrm{E}+02\end{array}$ & $\begin{array}{c}4.11 \mathrm{E}+01 \text { to } \\
6.72 \mathrm{E}+01\end{array}$ & $\begin{array}{c}3.60 \mathrm{E}+02 \\
\text { to } \\
6.18 \mathrm{E}+02\end{array}$ & $<6.91 \mathrm{E}+01$ & $<1.11 \mathrm{E}+02$ & $<1.39 \mathrm{E}+03$ & $\begin{array}{c}1.24 \mathrm{E}+02 \text { to } \\
1.51 \mathrm{E}+02\end{array}$ & $\begin{array}{c}5.99 \mathrm{E}+03 \text { to } \\
7.89 \mathrm{E}+03\end{array}$ & $\begin{array}{c}1.75 \mathrm{E}+02 \text { to } \\
3.80 \mathrm{E}+02\end{array}$ & $\begin{array}{c}1.35 \mathrm{E}+03 \text { to } \\
1.99 \mathrm{E}+03\end{array}$ \\
\hline $\mathrm{C}-106 \mathrm{Ca}(\mathrm{OH})_{2}$ & $<1.37 \mathrm{E}+03$ & $<2.74 \mathrm{E}+02$ & $\begin{array}{c}3.94 \mathrm{E}+04 \\
\text { to } \\
1.40 \mathrm{E}+05\end{array}$ & $<1.17 \mathrm{E}+02$ & $<2.74 \mathrm{E}+02$ & $<8.07 \mathrm{E}+04$ & $<5.47 \mathrm{E}+02$ & $<3.23 \mathrm{E}+02$ & $<5.47 \mathrm{E}+02$ & $\begin{array}{c}2.99 \mathrm{E}+03 \text { to } \\
6.12 \mathrm{E}+03\end{array}$ \\
\hline $\mathrm{C}-106 \mathrm{CaCO}_{3}$ & $\begin{array}{c}2.59 \mathrm{E}+03 \text { to } \\
5.50 \mathrm{E}+03\end{array}$ & $<2.74 \mathrm{E}+02$ & $\begin{array}{c}6.81 \mathrm{E}+03 \\
\text { to } \\
1.46 \mathrm{E}+04\end{array}$ & $<1.37 \mathrm{E}+02$ & $<2.74 \mathrm{E}+02$ & $<6.84 \mathrm{E}+04$ & $<5.49 \mathrm{E}+02$ & $<2.74 \mathrm{E}+02$ & $<5.49 \mathrm{E}+02$ & $<2.46 \mathrm{E}+03$ \\
\hline
\end{tabular}


Table 4.11. (contd)

\begin{tabular}{|c|c|c|c|c|c|c|c|c|c|c|}
\hline & $\begin{array}{c}\mathrm{Al} \\
(\mu \mathrm{g} / \mathrm{g})\end{array}$ & $\begin{array}{c}\mathrm{Ba} \\
(\mu \mathrm{g} / \mathrm{g})\end{array}$ & $\begin{array}{c}\text { Ca } \\
(\mu \mathrm{g} / \mathrm{g})\end{array}$ & $\begin{array}{c}\mathrm{Cr} \\
(\mu \mathrm{g} / \mathrm{g})\end{array}$ & $\begin{array}{c}\mathrm{Fe} \\
(\mu \mathrm{g} / \mathrm{g})\end{array}$ & $\begin{array}{c}\mathrm{K} \\
(\mu \mathrm{g} / \mathrm{g})\end{array}$ & $\begin{array}{c}\mathrm{Mg} \\
(\mu \mathrm{g} / \mathrm{g})\end{array}$ & $\begin{array}{c}\mathrm{Mn} \\
(\mu \mathrm{g} / \mathrm{g})\end{array}$ & $\begin{array}{c}\mathrm{Ni} \\
(\mu \mathrm{g} / \mathrm{g})\end{array}$ & $\begin{array}{c}\mathrm{Na} \\
(\mu \mathrm{g} / \mathrm{g})\end{array}$ \\
\hline \multicolumn{11}{|l|}{ Stage 4} \\
\hline C-106 Water Leach & $\begin{array}{c}6.31 \mathrm{E}+01 \text { to } \\
1.16 \mathrm{E}+02\end{array}$ & $\begin{array}{c}3.85 \mathrm{E}+01 \text { to } \\
9.57 \mathrm{E}+01\end{array}$ & $\begin{array}{c}3.40 \mathrm{E}+02 \\
\text { to } \\
8.31 \mathrm{E}+02\end{array}$ & $<6.91 \mathrm{E}+01$ & $<1.11 \mathrm{E}+02$ & $<1.39 \mathrm{E}+03$ & $(6.34 \mathrm{E}+01)$ & $\begin{array}{c}2.68 \mathrm{E}+3 \text { to } \\
3.67 \mathrm{E}+03\end{array}$ & $\begin{array}{c}2.17 \mathrm{E}+02 \text { to } \\
3.18 \mathrm{E}+02\end{array}$ & $\begin{array}{c}9.11 \mathrm{E}+02 \text { to } \\
1.45 \mathrm{E}+03\end{array}$ \\
\hline $\mathrm{C}-106 \mathrm{Ca}(\mathrm{OH})_{2}$ & $<1.37 \mathrm{E}+03$ & $<2.74 \mathrm{E}+02$ & $\begin{array}{c}1.67 \mathrm{E}+04 \\
\text { to } \\
6.63 \mathrm{E}+04\end{array}$ & $<1.17 \mathrm{E}+02$ & $<2.74 \mathrm{E}+02$ & $<8.07 \mathrm{E}+04$ & $<5.47 \mathrm{E}+02$ & $<3.23 \mathrm{E}+02$ & $<5.47 \mathrm{E}+02$ & $\begin{array}{c}4.93 \mathrm{E}+03 \text { to } \\
9.74 \mathrm{E}+03\end{array}$ \\
\hline $\mathrm{C}-106 \mathrm{CaCO}_{3}$ & $\begin{array}{c}4.09 \mathrm{E}+03 \text { to } \\
4.91 \mathrm{E}+03\end{array}$ & $<2.74 \mathrm{E}+02$ & $\begin{array}{c}9.81 \mathrm{E}+03 \\
\text { to } \\
1.23 \mathrm{E}+04\end{array}$ & $<1.37 \mathrm{E}+02$ & $<2.74 \mathrm{E}+02$ & $<6.84 \mathrm{E}+04$ & $<5.49 \mathrm{E}+02$ & $<2.74 \mathrm{E}+02$ & $<5.49 \mathrm{E}+02$ & $<2.46 \mathrm{E}+03$ \\
\hline \multicolumn{11}{|l|}{ Stage 5} \\
\hline C-106 Water Leach & $\begin{array}{c}6.64 \mathrm{E}+01 \text { to } \\
1.30 \mathrm{E}+02\end{array}$ & $\begin{array}{c}(2.04 \mathrm{E}+01) \\
\text { to } 2.32 \mathrm{E}+02\end{array}$ & $\begin{array}{c}4.30 \mathrm{E}+02 \\
\text { to } \\
8.72 \mathrm{E}+02\end{array}$ & $<1.37 \mathrm{E}+02$ & $<1.11 \mathrm{E}+02$ & $<1.39 \mathrm{E}+03$ & $(6.79 E+01)$ & $\begin{array}{c}1.32 \mathrm{E}+03 \text { to } \\
2.03 \mathrm{E}+03\end{array}$ & $\begin{array}{c}1.85 \mathrm{E}+02 \text { to } \\
2.29 \mathrm{E}+02\end{array}$ & $\begin{array}{c}8.84 \mathrm{E}+02 \text { to } \\
1.30 \mathrm{E}+02\end{array}$ \\
\hline $\mathrm{C}-106 \mathrm{Ca}(\mathrm{OH})_{2}$ & $<1.61 \mathrm{E}+03$ & $<2.74 \mathrm{E}+02$ & $\begin{array}{c}4.78 \mathrm{E}+04 \\
\text { to } \\
6.98 \mathrm{E}+04\end{array}$ & $<1.37 \mathrm{E}+02$ & $<2.74 \mathrm{E}+02$ & $<8.07 \mathrm{E}+04$ & $<5.47 \mathrm{E}+02$ & $<3.23 \mathrm{E}+02$ & $<5.47 \mathrm{E}+02$ & $\begin{array}{c}1.76 \mathrm{E}+03 \text { to } \\
2.93 \mathrm{E}+03\end{array}$ \\
\hline $\mathrm{C}-106 \mathrm{CaCO}_{3}$ & $\begin{array}{c}2.06 \mathrm{E}+3 \text { to } \\
4.53 \mathrm{E}+03\end{array}$ & $<2.74 \mathrm{E}+02$ & $\begin{array}{c}\begin{array}{c}4.75 \mathrm{E}+02 \\
\text { to } \\
9.14 \mathrm{E}+03\end{array}\end{array}$ & $<1.37 \mathrm{E}+02$ & $<2.74 \mathrm{E}+02$ & $<6.84 \mathrm{E}+04$ & $<5.49 \mathrm{E}+02$ & $<2.74 \mathrm{E}+02$ & $<5.49 \mathrm{E}+02$ & $<2.46 \mathrm{E}+03$ \\
\hline \multicolumn{11}{|l|}{ Stage 6} \\
\hline C-106 Water Leach & $<2.76 \mathrm{E}+01$ & $1.76 \mathrm{E}+01$ & $2.72 \mathrm{E}+02$ & $<6.91 \mathrm{E}+01$ & $<1.11 \mathrm{E}+01$ & $<2.76 \mathrm{E}+02$ & $3.74 \mathrm{E}+01$ & $1.23 \mathrm{E}+03$ & $5.92 \mathrm{E}+01$ & $4.06 \mathrm{E}+03$ \\
\hline $\mathrm{C}-106 \mathrm{Ca}(\mathrm{OH}) 2$ & $\begin{array}{c}1.61 \mathrm{E}+03 \text { to } \\
1.97 \mathrm{E}+03\end{array}$ & $<2.74 \mathrm{E}+02$ & $\begin{array}{c}1.18 \mathrm{E}+04 \\
\text { to } \\
3.12 \mathrm{E}+04\end{array}$ & $<1.37 \mathrm{E}+02$ & $<2.74 \mathrm{E}+02$ & $<8.07 \mathrm{E}+04$ & $<5.47 \mathrm{E}+02$ & $<3.23 \mathrm{E}+02$ & $<5.47 \mathrm{E}+02$ & $\begin{array}{c}4.26 \mathrm{E}+3 \text { to } \\
1.15 \mathrm{E}+04\end{array}$ \\
\hline $\mathrm{C}-106 \mathrm{CaCO}_{3}$ & $\begin{array}{c}3.99 \mathrm{E}+03 \text { to } \\
4.84 \mathrm{E}+03\end{array}$ & $<2.74 \mathrm{E}+02$ & $\begin{array}{c}9.12 \mathrm{E}+03 \\
\text { to } \\
1.23 \mathrm{E}+04\end{array}$ & $<1.37 \mathrm{E}+02$ & $<2.74 \mathrm{E}+02$ & $<6.84 \mathrm{E}+04$ & $<5.49 \mathrm{E}+02$ & $<2.74 \mathrm{E}+02$ & $<5.49 \mathrm{E}+02$ & $\begin{array}{c}(3.00 \mathrm{E}+02) \text { to } \\
6.05 \mathrm{E}+02\end{array}$ \\
\hline
\end{tabular}




\subsubsection{Anion Concentrations - Sequential Contact Leaching Test}

The leachable anion concentrations at the six stages of the sequential contact leaching test are listed in Table 4.12. The primary water leachable anions at Stage 1 were oxalate and carbonate, with much less leachable quantities of chloride and fluoride. Oxalate continues to leach from the sludge samples in measurable quantities at all stages of the test; however, the amount of carbonate leached is below the detection limit after stage 1. (The detection limit for carbonate is high at a level of about 10,000 $\mu \mathrm{g} / \mathrm{g}$ in water leached samples.) The amount of oxalate leaching from the sludge decreases fairly uniformly throughout the six stages of leaching.

The uniform release of oxalate does not occur in the simulated cement leach. Oxalate was measurable only in Stage 1 of the $\mathrm{Ca}(\mathrm{OH})_{2}$ leach. No other anions appear to be leachable in any of the other stages of the $\mathrm{Ca}(\mathrm{OH})_{2}$ or the $\mathrm{CaCO}_{3}$ extracts. It is difficult to compare the anion leaching data due to the elevated detection limits for the simulated cement lechating. The elevated detection limits are due to the higher hydroxide and carbonate concentrations in the prepared extraction solutions.

\subsubsection{Radioanalytical Results - Sequential Contact Leaching Test}

The results of the GEA analysis of the sequential contact leaching test for ${ }^{137} \mathrm{Cs}$ are listed in Table 4.13. The water leachable concentrations of ${ }^{137} \mathrm{Cs}$ for the first contacts were in the range of 1.83 to $2.88 \mu \mathrm{Ci} / \mathrm{g}$ for the C-106 sludge samples. The subsequent concentrations in each water leachate decrease by over a factor of ten compared to the initial level. This shows that a small amount of the ${ }^{137} \mathrm{Cs}$ is very leachable, but the remaining majority is relatively recalcitrant to water leaching. ${ }^{137} \mathrm{Cs}$ appears to be more mobile in the simulated cement leaches. ${ }^{137} \mathrm{Cs}$ was released in the $\mathrm{Ca}(\mathrm{OH})_{2}$ solution 1 to 5 times higher, 1.1 to $13.6 \mu \mathrm{Ci} / \mathrm{g}$, compared to the water leach. The release remained relatively stable for the first five stages. The sixth stage with a longer contact time (43 days) showed another increase in the concentration of 20.7 to $35.1 \mu \mathrm{Ci} / \mathrm{g}{ }^{137} \mathrm{Cs}$. The concentration of ${ }^{137} \mathrm{Cs}$ in the $\mathrm{CaCO}_{3}$ leaches were lower then the concentrations measured in the water or $\mathrm{Ca}(\mathrm{OH})_{2}$ leaches with leachable quantities, 0.0025 to $2.17 \mu \mathrm{Ci} / \mathrm{g}$, measured in the first five stages. In a manner similar to the $\mathrm{Ca}(\mathrm{OH})_{2}$ leach tests, the $\mathrm{CaCO}_{3}$ leach showed a spike in the ${ }^{137} \mathrm{Cs}$ concentration in the sixth stage, 4.42 to $6.32 \mu \mathrm{Ci} / \mathrm{g}$.

The ${ }^{239} \mathrm{Pu},{ }^{237} \mathrm{~Np},{ }^{241} \mathrm{Am}$, and ${ }^{90} \mathrm{Sr}$ leachable concentrations for the sequential contact tests are listed in Table 4.14. ${ }^{239} \mathrm{Pu}$ was not measured above its estimated quantitation limit (EQL) during any of the stages of leaching. Measurable quantities of leachable ${ }^{237} \mathrm{~Np}$ were measured at most stages of the water leach test. No detectable ${ }^{237} \mathrm{~Np}$ was measured in the $\mathrm{Ca}(\mathrm{OH})_{2}$ or $\mathrm{CaCO}_{3}$ tests. ${ }^{241}$ Am was only measured above its EQL during the first stage of the water test. The water leachability of ${ }^{90} \mathrm{Sr}$ for the first five stages is approximately constant within the range of 0.3 to $1.41 \mu \mathrm{g} / \mathrm{g}$. (Stage 6 leaching data are not available for the water-leach or $\mathrm{CaCO}_{3}$-leach tests.) Leachable ${ }^{90} \mathrm{Sr}$ increases when $\mathrm{Ca}(\mathrm{OH})_{2}$ is used as the leaching solution. At each stage, the concentrations are higher than the corresponding water leach stage with a range of 0.3 to $7.78 \mu \mathrm{g} / \mathrm{g}$ for the $\mathrm{Ca}(\mathrm{OH})_{2}$ leaches. The increase in $\mathrm{Sr}$ for the $\mathrm{Ca}(\mathrm{OH})_{2}$ leaches is likely due to cation exchange of $\mathrm{Ca}$ for $\mathrm{Sr}$ on the exchange sites. The $\mathrm{CaCO}_{3}$-leach tests show concentrations similar to the water leach tests. Because the $\mathrm{CaCO}_{3}$ leaches follow the $\mathrm{Ca}(\mathrm{OH})_{2}$ leaches using the same sludge material, it appears that the majority of the exchangeable $\mathrm{Sr}$ has been desorbed by the initial $\mathrm{Ca}(\mathrm{OH})_{2}$-leach tests. 
Table 4.12. Anion Concentrations Leached During Sequential Contact Tests

\begin{tabular}{|c|c|c|c|c|c|c|c|c|c|}
\hline & $\begin{array}{c}\text { Fluoride } \\
(\mu \mathrm{g} / \mathrm{g})\end{array}$ & $\begin{array}{l}\text { Chloride } \\
(\mu \mathrm{g} / \mathrm{g})\end{array}$ & $\begin{array}{l}\text { Nitrite } \\
(\mu \mathrm{g} / \mathrm{g})\end{array}$ & $\begin{array}{c}\text { Bromide } \\
(\mu \mathrm{g} / \mathrm{g})\end{array}$ & $\begin{array}{l}\text { Nitrate } \\
(\mu \mathrm{g} / \mathrm{g})\end{array}$ & $\begin{array}{c}\text { Carbonate } \\
(\mu \mathrm{g} / \mathrm{g})\end{array}$ & $\begin{array}{l}\text { Sulfate } \\
(\mu \mathrm{g} / \mathrm{g})\end{array}$ & $\begin{array}{c}\text { Oxalate } \\
(\mu \mathrm{g} / \mathrm{g})\end{array}$ & $\begin{array}{c}\text { Phosphate } \\
(\mu \mathrm{g} / \mathrm{g})\end{array}$ \\
\hline \multicolumn{10}{|l|}{ Stage 1} \\
\hline C-106 Water Leach & $\begin{array}{c}3.06 \mathrm{E}+01 \text { to } \\
4.00 \mathrm{E}+01\end{array}$ & $\begin{array}{c}7.96 \mathrm{E}+01 \text { to } \\
1.08 \mathrm{E}+2\end{array}$ & $<9.97 \mathrm{E}+01$ & $<1.06 \mathrm{E}+02$ & $<9.57 \mathrm{E}+01$ & $\begin{array}{c}1.16 \mathrm{E}+04 \text { to } \\
2.48 \mathrm{E}+04\end{array}$ & & $\begin{array}{c}2.68 \mathrm{E}+04 \text { to } \\
4.26 \mathrm{E}+04\end{array}$ & $<1.12 \mathrm{E}+02$ \\
\hline $\mathrm{C}-106 \mathrm{Ca}(\mathrm{OH})_{2}$ & $<1.28 \mathrm{E}+02$ & $<2.59 \mathrm{E}+02$ & $<4.95 \mathrm{E}+02$ & $<5.28 \mathrm{E}+02$ & $<4.75 \mathrm{E}+02$ & $<5.49 \mathrm{E}+04$ & $<4.49 \mathrm{E}+02$ & $\begin{array}{c}3.40 \mathrm{E}+2 \text { to } \\
5.87 \mathrm{E}+02\end{array}$ & $<6.52 \mathrm{E}+02$ \\
\hline $\mathrm{C}-106 \mathrm{CaCO}_{3}$ & $<1.28 \mathrm{E}+02$ & $<2.59 \mathrm{E}+02$ & $<4.95 \mathrm{E}+02$ & $<5.28 \mathrm{E}+02$ & $<4.75 \mathrm{E}+02$ & $<5.49 \mathrm{E}+04$ & $<4.49 \mathrm{E}+02$ & $<3.79 \mathrm{E}+02$ & $<5.54 \mathrm{E}+02$ \\
\hline \multicolumn{10}{|l|}{ Stage 2} \\
\hline C-106 Water Leach & $<2.59 \mathrm{E}+01$ & $\begin{array}{c}3.93 \mathrm{E}+01 \text { to } \\
7.19 \mathrm{E}+01\end{array}$ & $<9.97 \mathrm{E}+01$ & $<1.06 \mathrm{E}+02$ & $<9.57 \mathrm{E}+01$ & $<1.11 \mathrm{E}+04$ & $<9.05 \mathrm{E}+01$ & $\begin{array}{c}1.77 \mathrm{E}+04 \text { to } \\
2.30 \mathrm{E}+04\end{array}$ & $<1.12 \mathrm{E}+02$ \\
\hline $\mathrm{C}-106 \mathrm{Ca}(\mathrm{OH})_{2}$ & $<1.51 \mathrm{E}+02$ & $<3.05 \mathrm{E}+02$ & $<5.82 \mathrm{E}+02$ & $<6.21 \mathrm{E}+02$ & $<5.59 \mathrm{E}+02$ & $<6.45 \mathrm{E}+04$ & $<5.28 \mathrm{E}+02$ & $<4.45 \mathrm{E}+02$ & $<6.52 \mathrm{E}+02$ \\
\hline $\mathrm{C}-106 \mathrm{CaCO}_{3}$ & $<1.28 \mathrm{E}+02$ & $<2.59 \mathrm{E}+02$ & $<4.95 \mathrm{E}+02$ & $<5.28 \mathrm{E}+02$ & $<4.75 \mathrm{E}+02$ & $<5.49 \mathrm{E}+04$ & $<4.49 \mathrm{E}+02$ & $<3.79 \mathrm{E}+02$ & $<5.54 \mathrm{E}+02$ \\
\hline \multicolumn{10}{|l|}{ Stage 3} \\
\hline C-106 Water Leach & $<2.59 \mathrm{E}+01$ & $\begin{array}{c}3.00 \mathrm{E}+01 \text { to } \\
4.78 \mathrm{E}+01\end{array}$ & $<9.97 \mathrm{E}+01$ & $<1.06 \mathrm{E}+02$ & $<9.57 \mathrm{E}+01$ & $<1.11 \mathrm{E}+04$ & $<9.05 \mathrm{E}+01$ & $\begin{array}{c}1.18 \mathrm{E}+04 \text { to } \\
1.60 \mathrm{E}+04\end{array}$ & $<1.12 \mathrm{E}+02$ \\
\hline $\mathrm{C}-106 \mathrm{Ca}(\mathrm{OH})_{2}$ & $<1.51 \mathrm{E}+02$ & $<3.05 \mathrm{E}+02$ & $<5.82 \mathrm{E}+02$ & $<6.21 \mathrm{E}+02$ & $<5.59 \mathrm{E}+02$ & $<6.45 \mathrm{E}+04$ & $<5.28 \mathrm{E}+02$ & $<4.45 \mathrm{E}+02$ & $<6.52 \mathrm{E}+02$ \\
\hline $\mathrm{C}-106 \mathrm{CaCO}_{3}$ & $<1.28 \mathrm{E}+02$ & $<2.59 \mathrm{E}+02$ & $<4.95 \mathrm{E}+02$ & $<5.28 \mathrm{E}+02$ & $<4.75 \mathrm{E}+02$ & $<5.49 \mathrm{E}+04$ & $<4.49 \mathrm{E}+02$ & $<3.79 \mathrm{E}+02$ & $<5.54 \mathrm{E}+02$ \\
\hline \multicolumn{10}{|l|}{ Stage 4} \\
\hline C-106 Water Leach & $<2.59 \mathrm{E}+01$ & $<5.22 \mathrm{E}+01$ & $<9.97 \mathrm{E}+01$ & $<1.06 \mathrm{E}+02$ & $<9.57 \mathrm{E}+01$ & $<1.11 \mathrm{E}+04$ & $<9.05 \mathrm{E}+01$ & $\begin{array}{c}6.06 \mathrm{E}+03 \text { to } \\
7.44 \mathrm{E}+03 \\
\end{array}$ & $<1.12 \mathrm{E}+02$ \\
\hline $\mathrm{C}-106 \mathrm{Ca}(\mathrm{OH})_{2}$ & $<1.51 \mathrm{E}+02$ & $<3.05 \mathrm{E}+02$ & $<5.82 \mathrm{E}+02$ & $<6.21 \mathrm{E}+02$ & $<5.59 \mathrm{E}+02$ & $<6.45 \mathrm{E}+04$ & $<5.28 \mathrm{E}+02$ & $<4.45 \mathrm{E}+02$ & $<6.52 \mathrm{E}+02$ \\
\hline $\mathrm{C}-106 \mathrm{CaCO}_{3}$ & $<1.28 \mathrm{E}+02$ & $<2.59 \mathrm{E}+02$ & $<4.95 \mathrm{E}+02$ & $<5.28 \mathrm{E}+02$ & $<4.75 \mathrm{E}+02$ & $<5.49 \mathrm{E}+04$ & $<4.49 \mathrm{E}+02$ & $<3.79 \mathrm{E}+02$ & $<5.54 \mathrm{E}+02$ \\
\hline \multicolumn{10}{|l|}{ Stage 5} \\
\hline C-106 Water Leach & $<2.59 \mathrm{E}+01$ & $<5.22 \mathrm{E}+01$ & $<9.97 \mathrm{E}+01$ & $<1.06 \mathrm{E}+02$ & $<9.57 \mathrm{E}+01$ & $<1.11 \mathrm{E}+04$ & $<9.05 \mathrm{E}+01$ & $\begin{array}{c}1.73 \mathrm{E}+03 \text { to } \\
4.28 \mathrm{E}+03\end{array}$ & $<1.12 \mathrm{E}+02$ \\
\hline $\mathrm{C}-106 \mathrm{Ca}(\mathrm{OH})_{2}$ & $<1.51 \mathrm{E}+02$ & $<3.05 \mathrm{E}+02$ & $<5.82 \mathrm{E}+02$ & $<6.21 \mathrm{E}+02$ & $<5.59 \mathrm{E}+02$ & $<6.45 \mathrm{E}+04$ & $<5.28 \mathrm{E}+02$ & $<4.45 \mathrm{E}+02$ & $<6.52 \mathrm{E}+02$ \\
\hline $\mathrm{C}-106 \mathrm{CaCO}_{3}$ & $<1.28 \mathrm{E}+02$ & $<2.59 \mathrm{E}+02$ & $<4.95 \mathrm{E}+02$ & $<5.28 \mathrm{E}+02$ & $<4.75 \mathrm{E}+02$ & $<5.49 \mathrm{E}+04$ & $<4.49 \mathrm{E}+02$ & $<3.79 \mathrm{E}+02$ & $<5.54 \mathrm{E}+02$ \\
\hline \multicolumn{10}{|l|}{ Stage 6} \\
\hline C-106 Water Leach & $<2.59 \mathrm{E}+01$ & $<5.22 \mathrm{E}+01$ & $<9.97 \mathrm{E}+01$ & $<1.06 \mathrm{E}+02$ & $<9.57 \mathrm{E}+01$ & $<1.11 \mathrm{E}+04$ & $<9.05 \mathrm{E}+01$ & $3.80 \mathrm{E}+03$ & $1.98 \mathrm{E}+02$ \\
\hline $\mathrm{C}-106 \mathrm{Ca}(\mathrm{OH})_{2}$ & $<1.51 \mathrm{E}+02$ & $<3.05 \mathrm{E}+02$ & $<5.82 \mathrm{E}+02$ & $<6.21 \mathrm{E}+02$ & $<5.59 \mathrm{E}+02$ & $<6.45 \mathrm{E}+04$ & $<5.28 \mathrm{E}+02$ & $<4.45 \mathrm{E}+02$ & $<6.52 \mathrm{E}+02$ \\
\hline $\mathrm{C}-106 \mathrm{CaCO}_{3}$ & $<1.28 \mathrm{E}+02$ & $<2.59 \mathrm{E}+02$ & $<4.95 \mathrm{E}+02$ & $<5.28 \mathrm{E}+02$ & $<4.75 \mathrm{E}+02$ & $<5.49 \mathrm{E}+04$ & $<4.49 \mathrm{E}+02$ & $<3.79 \mathrm{E}+02$ & $<5.54 \mathrm{E}+02$ \\
\hline
\end{tabular}


Table 4.13. ${ }^{137}$ Cs Concentrations Leached During Sequential Contact Tests

\begin{tabular}{|c|c|c|}
\hline & $\begin{array}{c}{ }^{137} \mathrm{Cs} \\
(\mu \mathrm{Ci} / \mathrm{g})\end{array}$ & $\begin{array}{l}{ }^{{ }^{137} \mathrm{Cs}} \\
(\mu \mathrm{g} / \mathrm{g})\end{array}$ \\
\hline \multicolumn{3}{|l|}{ Stage 1} \\
\hline C-106 Water Leach & $1.83 \mathrm{E}+00$ to $2.88 \mathrm{E}+00$ & $2.10 \mathrm{E}-02$ to $3.31 \mathrm{E}-02$ \\
\hline $\mathrm{C}-106 \mathrm{Ca}(\mathrm{OH})_{2}$ & $1.10 \mathrm{E}+00$ to $7.31 \mathrm{E}+00$ & $1.26 \mathrm{E}-02$ to $8.40 \mathrm{E}-02$ \\
\hline $\mathrm{C}-106 \mathrm{CaCO}_{3}$ & $6.25 \mathrm{E}-02$ to $4.62 \mathrm{E}-01$ & 7.18E-04 to $5.31 \mathrm{E}-03$ \\
\hline \multicolumn{3}{|l|}{ Stage 2} \\
\hline C-106 Water Leach & 4.07E-02 to $2.15 \mathrm{E}-01$ & 4.67E-04 to $2.47 \mathrm{E}-03$ \\
\hline $\mathrm{C}-106 \mathrm{Ca}(\mathrm{OH})_{2}$ & $5.25 \mathrm{E}+00$ to $8.12 \mathrm{E}+00$ & 6.04E-02 to $9.34 \mathrm{E}-02$ \\
\hline $\mathrm{C}-106 \mathrm{CaCO}_{3}$ & $1.80 \mathrm{E}-02$ to $2.92 \mathrm{E}-02$ & 2.07E-04 to $3.36 \mathrm{E}-04$ \\
\hline \multicolumn{3}{|l|}{ Stage 3} \\
\hline C-106 Water Leach & $3.59 \mathrm{E}-02$ to $4.20 \mathrm{E}-02$ & 4.23E-04 to $4.82 \mathrm{E}-04$ \\
\hline $\mathrm{C}-106 \mathrm{Ca}(\mathrm{OH})_{2}$ & $2.87 \mathrm{E}+00$ to $5.78 \mathrm{E}+00$ & 3.30E-02 to $6.64 \mathrm{E}-02$ \\
\hline $\mathrm{C}-106 \mathrm{CaCO}_{3}$ & $2.25 \mathrm{E}-03$ to $8.06 \mathrm{E}-03$ & 2.59E-05 to $9.26 \mathrm{E}-05$ \\
\hline \multicolumn{3}{|l|}{ Stage 4} \\
\hline C-106 Water Leach & $<4.27 \mathrm{E}-02$ & $<4.90 \mathrm{E}-04$ \\
\hline $\mathrm{C}-106 \mathrm{Ca}(\mathrm{OH})_{2}$ & $7.44 \mathrm{E}+00$ to $1.36 \mathrm{E}+01$ & $8.55 \mathrm{E}-02$ to $1.78 \mathrm{E}-01$ \\
\hline $\mathrm{C}-106 \mathrm{CaCO}_{3}$ & $7.41 \mathrm{E}-03$ to $2.17 \mathrm{E}+00$ & 8.52E-05 to $2.50 \mathrm{E}-02$ \\
\hline \multicolumn{3}{|l|}{ Stage 5} \\
\hline C-106 Water Leach & $<4.27 \mathrm{E}-02$ & $<4.90 \mathrm{E}-04$ \\
\hline $\mathrm{C}-106 \mathrm{Ca}(\mathrm{OH})_{2}$ & $4.72 \mathrm{E}+00$ to $6.46 \mathrm{E}+00$ & $5.42 \mathrm{E}-02$ to $7.42 \mathrm{E}-02$ \\
\hline $\mathrm{C}-106 \mathrm{CaCO}_{3}$ & $2.79 \mathrm{E}-01$ to $5.89 \mathrm{E}-01$ & 3.21E-03 to $6.78 \mathrm{E}-03$ \\
\hline \multicolumn{3}{|l|}{ Stage 6} \\
\hline C-106 Water Leach & NA & NA \\
\hline $\mathrm{C}-106 \mathrm{Ca}(\mathrm{OH})_{2}$ & $2.07 \mathrm{E}+01$ to $3.51 \mathrm{E}+01$ & 2.56E-01 to $4.04 \mathrm{E}-1$ \\
\hline $\mathrm{C}-106 \mathrm{CaCO}_{3}$ & $4.42 \mathrm{E}+00$ to $6.32 \mathrm{E}+00$ & $5.07 \mathrm{E}-02$ to $7.27 \mathrm{E}-02$ \\
\hline
\end{tabular}


Table 4.14. ${ }^{90} \mathrm{Sr}$ and Actinide Concentrations Leached During Sequential Contact Tests

\begin{tabular}{|c|c|c|c|c|c|c|c|c|}
\hline & $\begin{array}{c}{ }^{90} \mathrm{Sr} \\
(\mu \mathrm{Ci} / \mathrm{g})\end{array}$ & $\begin{array}{c}{ }^{90} \mathrm{Sr} \\
(\mu \mathrm{g} / \mathrm{g}) \\
\end{array}$ & $\begin{array}{c}{ }^{239} \mathrm{Pu} \\
(\mu \mathrm{Ci} / \mathrm{g})\end{array}$ & $\begin{array}{l}{ }^{239} \mathrm{Pu} \\
(\mu \mathrm{g} / \mathrm{g})\end{array}$ & $\begin{array}{l}{ }^{237} \mathrm{~Np} \\
(\mu \mathrm{Ci} / \mathrm{g})\end{array}$ & $\begin{array}{l}{ }^{237} \mathrm{~Np} \\
(\mu \mathrm{g} / \mathrm{g}) \\
\end{array}$ & $\begin{array}{l}{ }^{241} \mathrm{Am} \\
(\mu \mathrm{Ci} / \mathrm{g})\end{array}$ & $\begin{array}{l}{ }^{241} \mathrm{Am} \\
(\mu \mathrm{g} / \mathrm{g})\end{array}$ \\
\hline \multicolumn{9}{|l|}{ Stage 1} \\
\hline C-106 Water Leach & $\begin{array}{c}4.34 \mathrm{E}+01 \text { to } \\
9.76 \mathrm{E}+01\end{array}$ & $\begin{array}{c}3.10 \mathrm{E}-01 \text { to } \\
6.97 \mathrm{E}-01\end{array}$ & $<1.71 \mathrm{E}-03$ & $<2.76 \mathrm{E}-02$ & $\begin{array}{c}5.06 \mathrm{E}-04 \text { to } \\
7.05 \mathrm{E}-4\end{array}$ & $\begin{array}{c}\text { 7.13E-01 to } \\
9.93 \mathrm{E}-01\end{array}$ & $2.57 \mathrm{E}-03$ & 7.55E-04 \\
\hline $\mathrm{C}-106 \mathrm{Ca}(\mathrm{OH})_{2}$ & $\begin{array}{c}4.22 \mathrm{E}+01 \text { to } \\
2.34 \mathrm{E}+02\end{array}$ & $\begin{array}{c}3.01 \mathrm{E}-01 \text { to } \\
1.67 \mathrm{E}+00 \\
\end{array}$ & $<4.00 \mathrm{E}-02$ & $<6.45 \mathrm{E}-01$ & $<4.58 \mathrm{E}-04$ & $<6.45 \mathrm{E}-01$ & $<1.10 \mathrm{E}+01$ & $<3.23 \mathrm{E}+00$ \\
\hline $\mathrm{C}-106 \mathrm{CaCO}_{3}$ & $\begin{array}{c}1.29 \mathrm{E}+02 \text { to } \\
3.79 \mathrm{E}+02\end{array}$ & $\begin{array}{c}9.21 \mathrm{E}-01 \text { to } \\
2.71 \mathrm{E}+00\end{array}$ & $<6.81 \mathrm{E}-03$ & $<1.10 \mathrm{E}-01$ & $<7.79 \mathrm{E}-05$ & $<1.10 \mathrm{E}-01$ & $<1.87 \mathrm{E}+00$ & $<5.49 \mathrm{E}-01$ \\
\hline \multicolumn{9}{|l|}{ Stage 2} \\
\hline C-106 Water Leach & $\begin{array}{c}7.13 \mathrm{E}+01 \text { to } \\
1.49 \mathrm{E}+02 \\
\end{array}$ & $\begin{array}{c}5.94 \mathrm{E}-01 \text { to } \\
1.06 \mathrm{E}+00\end{array}$ & $<1.71 \mathrm{E}-03$ & $<2.76 \mathrm{E}-02$ & $\begin{array}{c}2.08 \mathrm{E}-04 \text { to } \\
2.73 \mathrm{E}-04\end{array}$ & $\begin{array}{c}2.93 \mathrm{E}-01 \text { to } \\
3.84 \mathrm{E}-01\end{array}$ & $<3.76 \mathrm{E}-03$ & $<1.11 \mathrm{E}-03$ \\
\hline $\mathrm{C}-106 \mathrm{Ca}(\mathrm{OH})_{2}$ & $\begin{array}{c}2.98 \mathrm{E}+02 \text { to } \\
4.01 \mathrm{E}+02\end{array}$ & $\begin{array}{c}2.12 \mathrm{E}+00 \text { to } \\
2.86 \mathrm{E}+00\end{array}$ & $<4.00 \mathrm{E}-02$ & $<6.45 \mathrm{E}-01$ & $<4.58 \mathrm{E}-04$ & $<6.45 \mathrm{E}-01$ & $<1.10 \mathrm{E}+01$ & $<3.23 \mathrm{E}+00$ \\
\hline $\mathrm{C}-106 \mathrm{CaCO}_{3}$ & $\begin{array}{c}1.04 \mathrm{E}+02 \text { to } \\
1.58 \mathrm{E}+02\end{array}$ & $\begin{array}{c}7.43 \mathrm{E}-01 \text { to } \\
1.12 \mathrm{E}+00\end{array}$ & $<6.81 \mathrm{E}-03$ & $<1.10 \mathrm{E}-01$ & $<7.79 \mathrm{E}-05$ & $<1.10 \mathrm{E}-01$ & $<1.87 \mathrm{E}+00$ & $<5.49 \mathrm{E}-01$ \\
\hline \multicolumn{9}{|l|}{ Stage 3} \\
\hline C-106 Water Leach & $\begin{array}{c}1.02 \mathrm{E}+02 \text { to } \\
1.56 \mathrm{E}+02\end{array}$ & $\begin{array}{c}7.26 \mathrm{E}-01 \text { to } \\
1.12 \mathrm{E}+00 \\
\end{array}$ & $<1.71 \mathrm{E}-03$ & $<2.76 \mathrm{E}-02$ & $\begin{array}{c}1.36 \mathrm{E}-05 \text { to } \\
1.86 \mathrm{E}-05\end{array}$ & $\begin{array}{c}1.92 \mathrm{E}-02 \text { to } \\
2.61 \mathrm{E}-02\end{array}$ & $<3.76 \mathrm{E}-03$ & $<1.11 \mathrm{E}-03$ \\
\hline $\mathrm{C}-106 \mathrm{Ca}(\mathrm{OH})_{2}$ & $\begin{array}{c}1.79 \mathrm{E}+02 \text { to } \\
3.97 \mathrm{E}+02 \\
\end{array}$ & $\begin{array}{c}1.28 \mathrm{E}+00 \text { to } \\
2.84 \mathrm{E}+00\end{array}$ & $<4.00 \mathrm{E}-02$ & $<6.45 \mathrm{E}-01$ & $<4.58 \mathrm{E}-04$ & $<6.45 \mathrm{E}-01$ & $<1.10 \mathrm{E}+01$ & $<3.23 \mathrm{E}+00$ \\
\hline $\mathrm{C}-106 \mathrm{CaCO}_{3}$ & $\begin{array}{c}1.82 \mathrm{E}+01 \text { to } \\
9.56 \mathrm{E}+01\end{array}$ & $\begin{array}{c}1.30 \mathrm{E}-01 \text { to } \\
6.83 \mathrm{E}-01\end{array}$ & $<6.81 \mathrm{E}-03$ & $<1.10 \mathrm{E}-01$ & $<7.79 \mathrm{E}-05$ & $<1.10 \mathrm{E}-01$ & $<1.87 \mathrm{E}+00$ & $<5.49 \mathrm{E}-01$ \\
\hline \multicolumn{9}{|l|}{ Stage 4} \\
\hline C-106 Water Leach & $\begin{array}{c}8.79 \mathrm{E}+01 \text { to } \\
1.75 \mathrm{E}+02 \\
\end{array}$ & $\begin{array}{c}6.28 \mathrm{E}-01 \text { to } \\
1.25 \mathrm{E}+00 \\
\end{array}$ & $<1.71 \mathrm{E}-03$ & $<2.76 \mathrm{E}-02$ & $\begin{array}{c}7.65 \mathrm{E}-06 \text { to } \\
8.23 \mathrm{E}-06 \\
\end{array}$ & $\begin{array}{c}1.08 \mathrm{E}-02 \text { to } \\
1.16 \mathrm{E}-02\end{array}$ & $<3.76 \mathrm{E}-03$ & $<1.11 \mathrm{E}-03$ \\
\hline $\mathrm{C}-106 \mathrm{Ca}(\mathrm{OH})_{2}$ & $\begin{array}{c}4.52 \mathrm{E}+02 \text { to } \\
8.56 \mathrm{E}+02\end{array}$ & $\begin{array}{c}3.23 \mathrm{E}+00 \text { to } \\
6.11 \mathrm{E}+00\end{array}$ & $<4.00 \mathrm{E}-02$ & $<6.45 \mathrm{E}-01$ & $<4.58 \mathrm{E}-04$ & $<6.45 \mathrm{E}-01$ & $<1.10 \mathrm{E}+01$ & $<3.23 \mathrm{E}+00$ \\
\hline $\mathrm{C}-106 \mathrm{CaCO}_{3}$ & $\begin{array}{c}6.88 \mathrm{E}+01 \text { to } \\
1.54 \mathrm{E}+02\end{array}$ & $\begin{array}{c}4.91 \mathrm{E}-01 \text { to } \\
1.08 \mathrm{E}+00\end{array}$ & $<6.81 \mathrm{E}-03$ & $<1.10 \mathrm{E}-01$ & $<7.79 \mathrm{E}-05$ & $<1.10 \mathrm{E}-01$ & $<1.87 \mathrm{E}+00$ & $<5.49 \mathrm{E}-01$ \\
\hline
\end{tabular}


Table 4.14. (contd)

\begin{tabular}{|c|c|c|c|c|c|c|c|c|}
\hline & $\begin{array}{c}{ }^{90} \mathrm{Sr} \\
(\mu \mathrm{Ci} / \mathrm{g}) \\
\end{array}$ & $\begin{array}{r}{ }^{90} \mathrm{Sr} \\
(\mu \mathrm{g} / \mathrm{g}) \\
\end{array}$ & $\begin{array}{c}{ }^{239} \mathrm{Pu} \\
(\mu \mathrm{Ci} / \mathrm{g}) \\
\end{array}$ & $\begin{array}{r}{ }^{239} \mathrm{Pu} \\
(\mu \mathrm{g} / \mathrm{g}) \\
\end{array}$ & $\begin{array}{c}{ }^{237} \mathrm{~Np} \\
(\mu \mathrm{Ci} / \mathrm{g})\end{array}$ & $\begin{array}{l}{ }^{237} \mathrm{~Np} \\
(\mu \mathrm{g} / \mathrm{g}) \\
\end{array}$ & $\begin{array}{l}{ }^{241} \mathrm{Am} \\
(\mu \mathrm{Ci} / \mathrm{g})\end{array}$ & $\begin{array}{l}{ }^{241} \mathrm{Am} \\
(\mu \mathrm{g} / \mathrm{g}) \\
\end{array}$ \\
\hline \multicolumn{9}{|l|}{ Stage 5} \\
\hline C-106 Water Leach & $\begin{array}{c}8.98 \mathrm{E}+01 \text { to } \\
1.97 \mathrm{E}+02\end{array}$ & $\begin{array}{c}\text { 6.42E-01 to } \\
1.41 \mathrm{E}+00\end{array}$ & $<1.71 \mathrm{E}-03$ & $<2.76 \mathrm{E}-02$ & $\begin{array}{c}.96 \mathrm{E}-06 \text { to } \\
5.37 \mathrm{E}-06\end{array}$ & $\begin{array}{c}6.99 \mathrm{E}-03 \text { to } \\
7.56 \mathrm{E}-03\end{array}$ & $<3.76 \mathrm{E}-03$ & $<1.11 \mathrm{E}-03$ \\
\hline $\mathrm{C}-106 \mathrm{Ca}(\mathrm{OH})_{2}$ & $\begin{array}{c}3.71 \mathrm{E}+02 \text { to } \\
8.08 \mathrm{E}+02\end{array}$ & $\begin{array}{c}2.65 \mathrm{E}+00 \text { to } \\
5.77 \mathrm{E}+00\end{array}$ & $<4.00 \mathrm{E}-02$ & $<6.45 \mathrm{E}-01$ & $<4.58 \mathrm{E}-04$ & $<6.45 \mathrm{E}-01$ & $<1.10 \mathrm{E}+01$ & $<3.23 \mathrm{E}+00$ \\
\hline $\mathrm{C}-106 \mathrm{CaCO}_{3}$ & $\begin{array}{c}3.83 \mathrm{E}+01 \text { to } \\
6.68 \mathrm{E}+01\end{array}$ & $\begin{array}{c}2.74 \mathrm{E}-01 \text { to } \\
4.77 \mathrm{E}-01 \\
\end{array}$ & $<6.81 \mathrm{E}-03$ & $<1.10 \mathrm{E}-01$ & $<7.79 \mathrm{E}-05$ & $<1.10 \mathrm{E}-01$ & $<1.87 \mathrm{E}+00$ & $<5.49 \mathrm{E}-01$ \\
\hline \multicolumn{9}{|l|}{ Stage 6} \\
\hline C-106 Water Leach & NA & NA & $<1.71 \mathrm{E}-03$ & $<2.76 \mathrm{E}-02$ & $2.68 \mathrm{E}-04$ & 3.78E-01 & $<3.76 \mathrm{E}-03$ & $<1.11 \mathrm{E}-03$ \\
\hline $\mathrm{C}-106 \mathrm{Ca}(\mathrm{OH})_{2}$ & $\begin{array}{c}4.20 \mathrm{E}+02 \text { to } \\
1.09 \mathrm{E}+03\end{array}$ & $\begin{array}{c}3.00 \mathrm{E}+00 \text { to } \\
7.78 \mathrm{E}+00\end{array}$ & $<4.00 \mathrm{E}-02$ & $<6.45 \mathrm{E}-01$ & $<4.58 \mathrm{E}-04$ & $<6.45 \mathrm{E}-01$ & $<1.10 \mathrm{E}+01$ & $<3.23 \mathrm{E}+00$ \\
\hline $\mathrm{C}-106 \mathrm{CaCO}_{3}$ & NA & NA & $<6.81 \mathrm{E}-03$ & $<1.10 \mathrm{E}-01$ & $<7.79 \mathrm{E}-05$ & $<1.10 \mathrm{E}-01$ & $<1.87 \mathrm{E}+00$ & $<5.49 \mathrm{E}-01$ \\
\hline
\end{tabular}




\subsection{XRD Results}

This section describes the crystalline solids identified by XRD for the 1-month and Stage 6 sequential samples of residual waste from tank C-106 leached with $\mathrm{Ca}(\mathrm{OH})_{2}$ and $\mathrm{CaCO}_{3}$. The as-measured and background-subtracted XRD patterns for these samples are found in Appendix A. Phase identification was based on a comparison of the peak reflections and intensities observed in each pattern to the mineral powder diffraction files (PDFTM) published by the Joint Committee on Powder Diffraction Standards (JCPDS) International Center for Diffraction Data (ICDD). Phase identification from the XRD patterns was refined in an iterative fashion by considering phases with particle compositions that were determined by SEM/EDS (see Section 4.3) to be present in the residual waste samples. The XRD patterns in Appendix A show greater detail than those plotted in this section because they do not include the schematic PDF-XRD database patterns (as plotted in this section) used for phase identification.

Each pattern in this section and Appendix $\mathrm{A}$ is shown as a function of degrees $2 \theta$ based on $\mathrm{Cu}_{\mathrm{K} \alpha}$ radiation ( $\lambda=1.5406 \AA$ ). The vertical axis in each pattern represents the relative intensity of the XRD peaks. As noted in Section 3.3, trace quantities of reference-material corundum $\left(\alpha-\mathrm{Al}_{2} \mathrm{O}_{3}\right.$, alumina) powder were added to each XRD mount to provide an internal $2 \theta$ standard for each XRD pattern. The schematic database (PDF) patterns considered for phase identification are shown, for comparison purposes, in the first two figures in this section. The height of each line in the schematic PDF patterns represents the relative intensity of an XRD peak (i.e., the most intense [the highest] peak has a relative intensity $\left[\mathrm{I} / \mathrm{I}_{0}\right]$ of $100 \%$ ). Quantitative analyses of the relative masses of individual phases present in each solid sample were not estimated using these XRD patterns due to the factors discussed at the end of Section 3.3. Also, as noted previously in Section 3.3, a crystalline phase typically must be present at greater than $5 \mathrm{wt} \%$ of the total sample mass (greater than $1 \mathrm{wt} \%$ under optimum conditions) to be readily detected by XRD.

The as-measured XRD patterns (not background subtracted) measured for the 1-month and Stage 6 sequential $\mathrm{Ca}(\mathrm{OH})_{2}$-leached and the 1-month and Stage 6 sequential $\mathrm{CaCO}_{3}$-leached samples are shown in Figure 4.1 and Figure 4.2, respectively. Minerals identified in the two $\mathrm{Ca}(\mathrm{OH})_{2}$-leached samples (Figure 4.1) include gibbsite $\left[\mathrm{Al}(\mathrm{OH})_{3}\right]$, whewellite (Ca oxalate monohydrate, $\mathrm{CaC}_{2} \mathrm{O}_{4} \cdot \mathrm{H}_{2} \mathrm{O}$ ), calcite $\left(\mathrm{CaCO}_{3}\right)$, and corundum (the internal standard). The XRD patterns for the $\mathrm{Ca}(\mathrm{OH})_{2}$-leached samples are also consistent with the possible presence of böhmite $[\mathrm{AlO}(\mathrm{OH})]$. Gibbsite, whewellite, calcite, and corundum (the internal standard) were also identified in the XRD patterns for the two $\mathrm{CaCO}_{3}$-leached samples (Figure 4.2). The XRD pattern for the 1-month $\mathrm{CaCO}_{3}$-leached sample also contained reflections that were consistent with the possible presence of dawsonite $\left[\mathrm{NaAlCO}_{3}(\mathrm{OH})_{2}\right]$. Calcite was identified in the $\mathrm{Ca}(\mathrm{OH})_{2}$ - and $\mathrm{CaCO}_{3}$-leached samples by the reflections at $29.40,39.57$, and $39.41^{\circ} 2 \theta$. No other new carbonate phases were detected by XRD analysis of the $\mathrm{Ca}(\mathrm{OH})_{2}$ - and $\mathrm{CaCO}_{3}$-leached samples of $\mathrm{C}-106$ residual waste.

There were no unassigned reflections in the background-subtracted XRD patterns for $\mathrm{Ca}(\mathrm{OH})_{2}$-and $\mathrm{CaCO}_{3}$-leached samples (Figure 4.1 and Figure 4.2, respectively). This suggests that all crystalline phases present at greater than 5-10 wt\% in these residual waste samples were identified by XRD. No other new carbonate phases were detected by XRD analysis of the $\mathrm{Ca}(\mathrm{OH})_{2}$ - and $\mathrm{CaCO}_{3}$-leached samples of C-106 residual waste. 


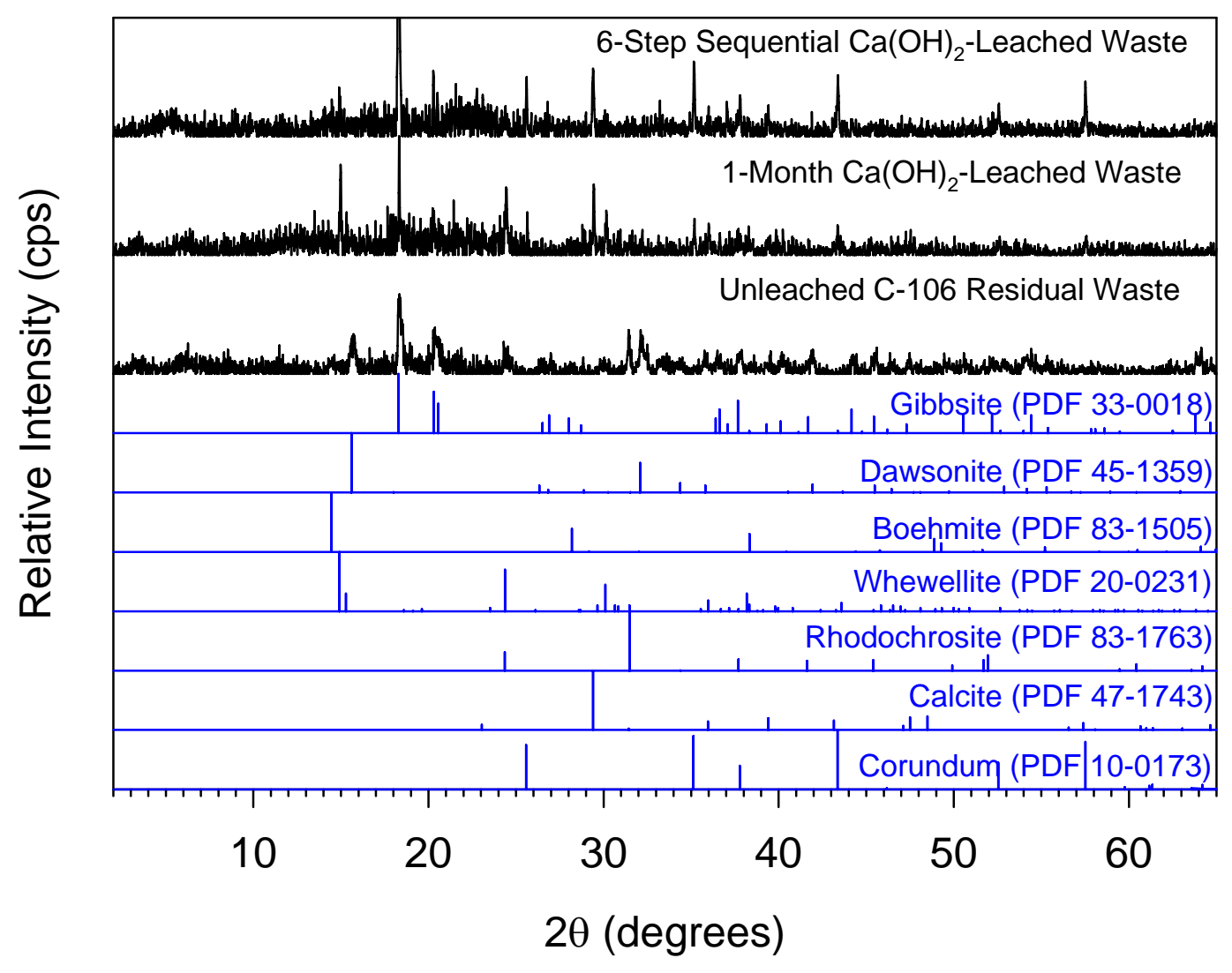

Figure 4.1. Background-Subtracted XRD Patterns (in black) for 1-Month and Stage 6 Sequential $\mathrm{Ca}(\mathrm{OH})_{2}$-Leached and for Unleached C-106 Residual Waste Compared to the Matching PDF Database Patterns (in blue)

The background-subtracted XRD patterns for the $\mathrm{Ca}(\mathrm{OH})_{2}$ - and $\mathrm{CaCO}_{3}$-leached samples are generally very similar to each other. Figure 4.3 shows a comparison of the XRD patterns for the 1 -month $\mathrm{Ca}(\mathrm{OH})_{2^{-}}$ and 1-month $\mathrm{CaCO}_{3}$-leached samples of $\mathrm{C}$-106 residual waste.

Table 4.15 gives a comparison of the XRD and SEM/EDS results for the $\mathrm{Ca}(\mathrm{OH})_{2}$-and $\mathrm{CaCO}_{3^{-}}$ leached samples relative to those from Deutsch et al. (2005b) for the C-106 residual waste used as starting material for these leaching tests. Except for the presence of calcite $\left(\mathrm{CaCO}_{3}\right)$, the phases identified from the XRD patterns for the $\mathrm{Ca}(\mathrm{OH})_{2}$-and $\mathrm{CaCO}_{3}$-leached samples were also present in the XRD patterns for the C-106 starting material. Absent from the XRD patterns for the leached samples, however, were hematite $\left(\mathrm{Fe}_{2} \mathrm{O}_{3}\right)$, lindbergite $\left(\mathrm{MnC}_{2} \mathrm{O}_{4} \cdot 2 \mathrm{H}_{2} \mathrm{O}\right)$, rhodochrosite $\left(\mathrm{MnCO}_{3}\right)$, which were identified in the starting material. Identification of böhmite $[\mathrm{AlO}(\mathrm{OH})]$ and dawsonite $\left[\mathrm{NaAlCO}_{3}(\mathrm{OH})_{2}\right]$ in the $\mathrm{Ca}(\mathrm{OH})_{2^{-}}$ leached and the 1-month leached $\mathrm{CaCO}_{3}$-leached samples, respectively, was problematic and therefore need to also be considered as possibly absent in the $\mathrm{Ca}(\mathrm{OH})_{2}$-and $\mathrm{CaCO}_{3}$-leached samples. It was not possible from the XRD or SEM/EDS analyses (see Section 4.3) to determine if the lack of identification 
of hematite, lindbergite, rhodochrosite $\left(\mathrm{MnCO}_{3}\right)$, böhmite, and dawsonite is due to their dissolution during contact with the $\mathrm{Ca}(\mathrm{OH})_{2}$ and $\mathrm{CaCO}_{3}$ leachates and/or to their presence being at concentrations too low to be detected by bulk XRD.

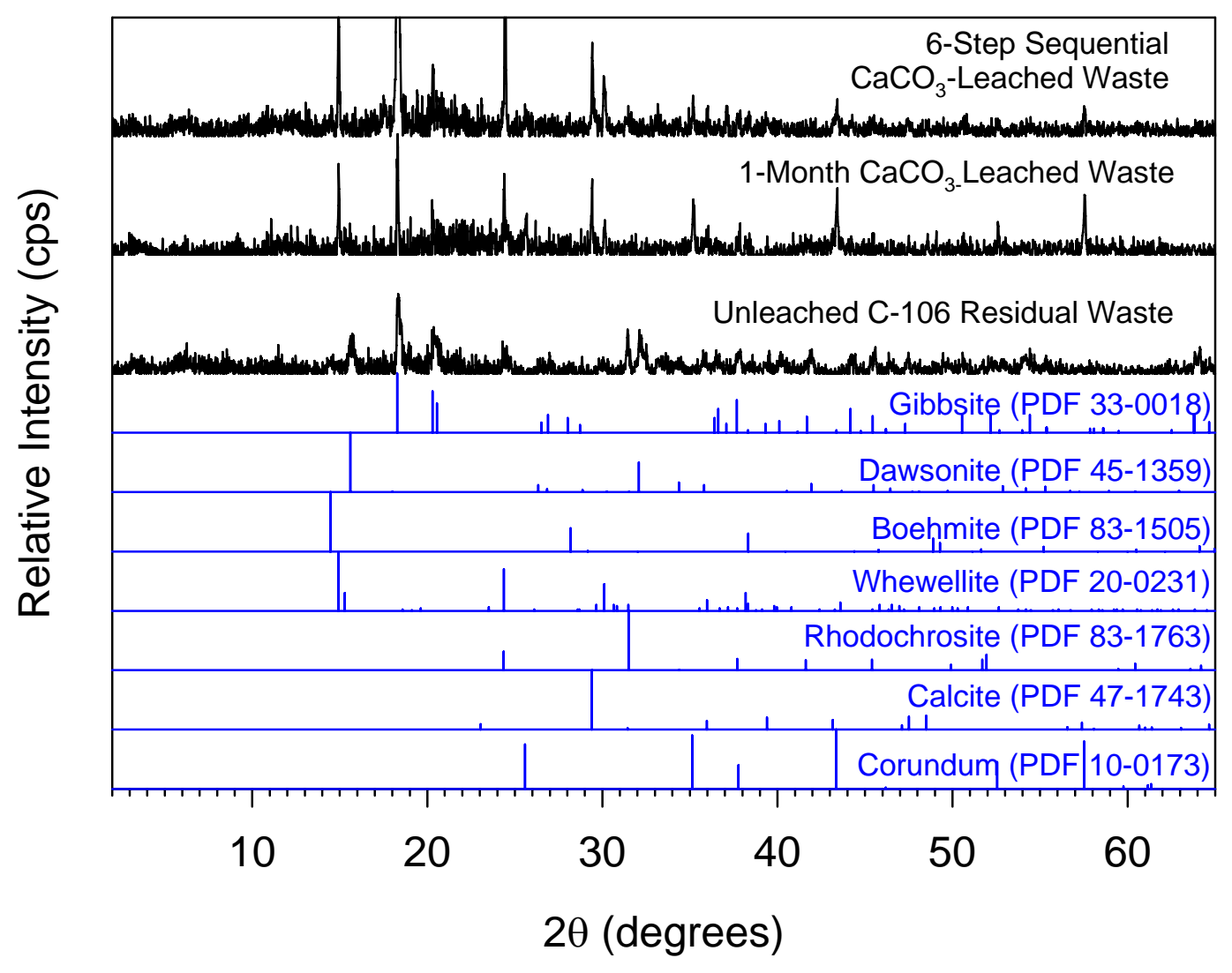

Figure 4.2. Background-Subtracted XRD Patterns (in black) for 1-Month and Stage 6 Sequential $\mathrm{CaCO}_{3}$-Leached and for Unleached C-106 Residual Waste Compared to the Matching PDF Database Patterns (in blue)

There are minor differences in peak intensities between the XRD patterns for the $\mathrm{Ca}(\mathrm{OH})_{2}$-and $\mathrm{CaCO}_{3}$-leached samples and the pattern for the C-106 residual waste. Although some of these differences may be due to minor differences in the sample mounts, the XRD data suggests that the relative abundance of whewellite may be greater in the $\mathrm{Ca}(\mathrm{OH})_{2}$-leached samples than in the unleached $\mathrm{C}-106$ residual waste. Because of the hazardous nature of these sludge samples, it is not possible to control the exact amount of material used for each XRD mount. However, when these XRD mounts are prepared, a concerted effort is made to follow the same procedure and use the same amount of sludge material as closely as possible. 


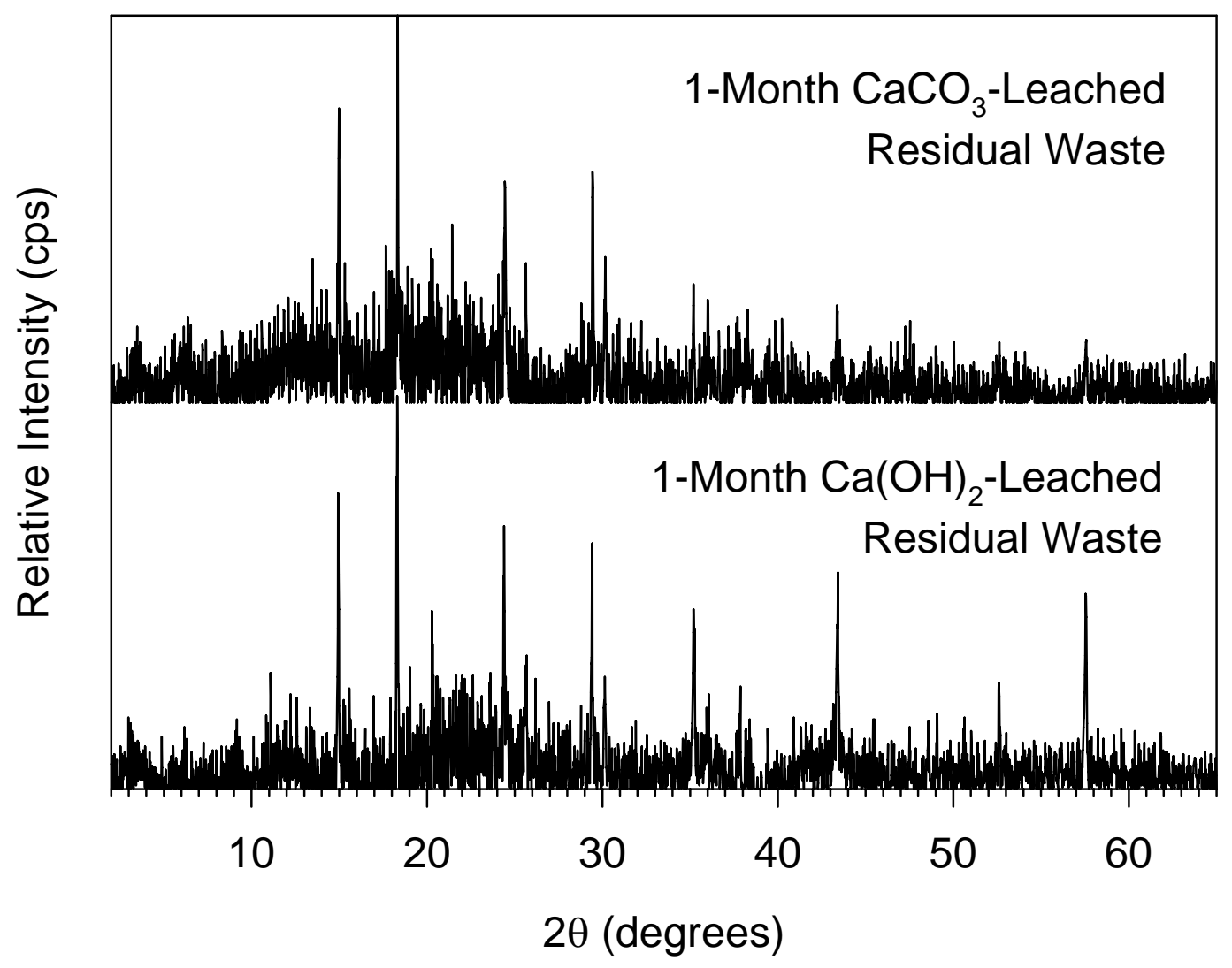

Figure 4.3. Comparison of Background-Subtracted XRD Patterns for 1-Month $\mathrm{Ca}(\mathrm{OH})_{2}$ - (bottom pattern) and 1-Month $\mathrm{CaCO}_{3}$ - (top pattern) Leached Samples of Unleached C-106 Residual Waste

\subsection{SEM/EDS Results}

This section discusses the results of the SEM/EDS analyses for the 1-month and Stage 6 sequential $\mathrm{Ca}(\mathrm{OH})_{2}$ - and $\mathrm{CaCO}_{3}$-leached samples of residual waste from tank C-106. The SEM micrographs presented in this section show representative morphologies, sizes, surface textures, and composition data for particles in these samples. All of the SEM micrographs and EDS spectra obtained for these samples are shown in Appendices B [1-month $\mathrm{Ca}(\mathrm{OH})_{2}$-leached], C [Stage 6 sequential $\mathrm{Ca}(\mathrm{OH})_{2}$-leached], D [1-month $\mathrm{CaCO}_{3}$-leached], and $\mathrm{E}$ [Stage 6 sequential $\mathrm{CaCO}_{3}$-leached]. Each micrograph included in this section and Appendices B through E lists the identification number for the digital micrograph image file, descriptor for the type of sample, and a size scale bar, respectively, at the bottom left, center, and right of each SEM micrograph. Micrographs labeled BSE near the digital file identification number indicate that the micrographs were collected by backscattered electron imaging. Areas outlined by white dashed-line squares or particles marked by arrows in a micrograph designate material that is imaged at higher 
Table 4.15. Comparison of XRD and SEM/EDS Results for the Unleached Samples of Residual Waste from Tank C-106 (from Deutsch et al. 2005a) to the Results for the $\mathrm{Ca}(\mathrm{OH})_{2}$ - and $\mathrm{CaCO}_{3}$-Leached Samples

\begin{tabular}{|c|c|c|c|c|c|}
\hline \multicolumn{2}{|c|}{$\begin{array}{l}\text { Unleached Oxalic Acid-Treated Residual Waste } \\
\text { (from Deutsch et al. 2005b) }\end{array}$} & \multicolumn{2}{|c|}{$\begin{array}{c}\mathrm{Ca}(\mathrm{OH})_{2} \text {-Leached Residual Waste: } \\
\text { 1-Month and Stage } 6 \text { Sequential Leaches } \\
\text { (from this study) }\end{array}$} & \multicolumn{2}{|c|}{$\begin{array}{c}\mathrm{CaCO}_{3} \text {-Leached Residual Waste: } \\
\text { 1-Month and Stage } 6 \text { Sequential Leaches } \\
\text { (from this study) }\end{array}$} \\
\hline XRD Analyses & SEM/EDS Analyses & XRD Analyses & SEM/EDS Analyses & XRD Analyses & SEM/EDS Analyses \\
\hline & $\begin{array}{c}\text { Mn-Al-Fe-Na-P-Si-Ca- } \\
\text { O } \pm \mathrm{C} \pm \mathrm{H}\end{array}$ & & & & \\
\hline & & & $\begin{array}{c}\text { Ca-Mn-Al-Si-Fe- } \\
\pm \mathrm{Pb} \pm \mathrm{REE}(\mathrm{Ce}) \pm \mathrm{Cr}-\mathrm{P}-\mathrm{O} \pm \\
\mathrm{C} \pm \mathrm{H}\end{array}$ & & $\begin{array}{c}\text { Ca-Mn-Al-Si-Fe- } \\
\pm \mathrm{Pb} \pm \mathrm{REE}(\mathrm{Ce}) \pm \mathrm{Cr}-\mathrm{P}-\mathrm{O} \pm \\
\mathrm{C} \pm \mathrm{H}\end{array}$ \\
\hline & & & $\begin{array}{l}\text { Ca-Al-O-C } \pm \mathrm{H} \text { (only in } \\
\text { Stage } 6 \text { sequential leach) }\end{array}$ & & $\mathrm{Ca}-\mathrm{Al}-\mathrm{O}-\mathrm{C} \pm \mathrm{H}$ \\
\hline Gibbsite $\left[\mathrm{Al}(\mathrm{OH})_{3}\right]$ & \multirow{2}{*}{$\mathrm{Al}-\mathrm{O} \pm \mathrm{H}$} & Gibbsite & \multirow{2}{*}{$\mathrm{Al}-\mathrm{O} \pm \mathrm{H} \pm \mathrm{C}$} & Gibbsite & $\mathrm{Al}-\mathrm{O} \pm \mathrm{H} \pm \mathrm{C}$ \\
\hline Böhmite $[\mathrm{AlO}(\mathrm{OH})]$ & & Böhmite (possibly) & & & \\
\hline $\begin{array}{c}\text { Dawsonite } \\
{\left[\mathrm{NaAlCO}_{3}(\mathrm{OH})_{2}\right]}\end{array}$ & $\mathrm{Al}-\mathrm{Na}-\mathrm{O}-\mathrm{C} \pm \mathrm{H}$ & & & $\begin{array}{l}\text { Dawsonite (only in } \\
\text { 1-month leached) }\end{array}$ & \\
\hline Hematite $\left(\mathrm{Fe}_{3} \mathrm{O}_{4}\right)$ & $\begin{array}{c}\text { Fe-Cr-O } \pm \mathrm{C} \pm \mathrm{H} \\
\text { Fe-Mn-O } \pm \mathrm{C} \pm \mathrm{H}\end{array}$ & & & & \\
\hline $\begin{array}{c}\text { Rhodochrosite } \\
\left(\mathrm{MnCO}_{3}\right)\end{array}$ & \multirow{2}{*}{$\begin{array}{c}\text { Mn-O-C } \pm \mathrm{H} \text { (possibly two } \\
\text { different phases based on } \\
\text { morphology) }\end{array}$} & & & & \\
\hline $\begin{array}{c}\text { Lindbergite } \\
\left(\mathrm{MnC}_{2} \mathrm{O}_{4} \cdot 2 \mathrm{H}_{2} \mathrm{O}\right)\end{array}$ & & & & & \\
\hline \multirow[t]{2}{*}{$\begin{array}{c}\text { Whewellite } \\
\left(\mathrm{CaC}_{2} \mathrm{O}_{4} \cdot \mathrm{H}_{2} \mathrm{O}\right)\end{array}$} & $\mathrm{Ca}-\mathrm{O} \pm \mathrm{C} \pm \mathrm{H}$ & Whewellite & \multirow[t]{2}{*}{$\mathrm{Ca}-\mathrm{O} \pm \mathrm{C} \pm \mathrm{H}$} & Whewellite & \multirow[t]{2}{*}{$\mathrm{Ca}-\mathrm{O} \pm \mathrm{C} \pm \mathrm{H}$} \\
\hline & & Calcite $\left(\mathrm{CaCO}_{3}\right)$ & & Calcite & \\
\hline Possible Ag-Hg phase & $\begin{array}{c}\text { Possibly } 1 \text { or } 2 \text { phases with } \\
\mathrm{Ag}-\mathrm{Hg} \pm \mathrm{Fe} \pm \mathrm{Pb} \pm \mathrm{Cu} \pm \mathrm{O} \pm \mathrm{H}\end{array}$ & & Ag-Hg (small particles) & & Ag-Hg (small particles) \\
\hline
\end{tabular}


Table 4.15. (contd)

\begin{tabular}{|c|c|c|c|c|c|}
\hline \multicolumn{2}{|c|}{$\begin{array}{l}\text { Unleached Oxalic Acid-Treated Residual Waste } \\
\text { (from Deutsch et al. 2005b) }\end{array}$} & \multicolumn{2}{|c|}{$\begin{array}{c}\mathrm{Ca}(\mathrm{OH})_{2} \text {-Leached Residual Waste: } \\
\text { 1-Month and Stage } 6 \text { Sequential Leaches } \\
\text { (from this study) }\end{array}$} & \multicolumn{2}{|c|}{$\begin{array}{c}\mathrm{CaCO}_{3} \text {-Leached Residual Waste: } \\
\text { 1-Month and Stage 6 Sequential Leaches } \\
\text { (from this study) }\end{array}$} \\
\hline XRD Analyses & SEM/EDS Analyses & XRD Analyses & SEM/EDS Analyses & XRD Analyses & SEM/EDS Analyses \\
\hline & REE-rich oxide & & & & \\
\hline & $\mathrm{Ca}-\mathrm{Si}-\mathrm{Al}-\mathrm{O} \pm \mathrm{C} \pm \mathrm{H}$ & & & & \\
\hline & Pb-containing phase & & & & \\
\hline
\end{tabular}


magnification. They are typically shown in the next several figures for that sample series. Micrographs presented in this section are typically reproduced at reduced size to conserve page space. For more detailed views of these micrographs, the reader is referred to Appendices B through $\mathrm{E}$, where the micrographs are shown at a larger size.

Figure 4.4 shows SEM micrographs obtained at relatively low magnification of material present in $\mathrm{Ca}(\mathrm{OH})_{2}$-leached (top row) and $\mathrm{CaCO}_{3}$-leached (bottom row) residual waste from tank $\mathrm{C}-106$. The 1-month and Stage 6 sequential leaches for each of these treatments are shown in the left and right columns of Figure 4.4. Generally, the material in the 1-month $\mathrm{Ca}(\mathrm{OH})_{2}$ - and 1-month $\mathrm{CaCO}_{3}$-leached samples appear to be more disaggregated than the material in the Stage 6 sequential leaches of each treatment. It is not known if the disintegration resulted from dissolution of interstitial phases in the particle aggregates during the 1-month leach treatments or from solution sampling where more fines could have been discarded during leachate replenishment for the six stages of sequential leaches. The latter scenario seems unlikely because the sample tubes were centrifuged and spun at 4,000 rpm for 20 minutes prior to carefully decanting off each supernatant for chemical analysis.

Figure 4.5 shows for comparison low magnification SEM micrographs from Deutsch et al. (2005a) of particles in the unleached (top row), 1-month water-leached (left on bottom row), and HF stage 1 extract (right on bottom row) of residual waste from tank C-106. The unleached waste is the starting material for the $\mathrm{Ca}(\mathrm{OH})_{2}$ leach tests. Generally, the 1-month $\mathrm{Ca}(\mathrm{OH})_{2}$ - and 1-month $\mathrm{CaCO}_{3}$-leached samples (left column in Figure 4.4) appear to be more disintegrated than the unleached residual waste (top row of Figure 4.5). The materials resulting from the Stage 6 sequential leaches (right column in Figure 4.4) are more similar to the materials from the 1-month water-leached and HF stage 1 extract (bottom row of Figure 4.5) samples.

Figure 4.6 through Figure 4.11 show micrographs collected at higher magnification and spectra for areas analyzed by EDS of some of the more common particles and aggregates present in the $\mathrm{Ca}(\mathrm{OH})_{2^{-}}$ and $\mathrm{CaCO}_{3}$-leached samples. The particles and aggregates are very similar to those presented in Deutsch et al. (2005b) for unleached C-106 residual waste. The EDS analyses are summarized in Table 4.1. The EDS results indicate that the $\mathrm{Ca}(\mathrm{OH})_{2}$ - and $\mathrm{CaCO}_{3}$-leached samples include particles consisting of primarily the following five compositions:

- Ca-Mn-Al-Si-Fe- $\pm \mathrm{Pb} \pm \mathrm{REE}(\mathrm{Ce}) \pm \mathrm{Cr}$ (trace)-P-O $\pm \mathrm{C} \pm \mathrm{H}$ - Figure 4.6 (spectrum 2), Figure 4.7 (spectra 1 and 2), Figure 4.9 (spectra 1, 3, and 4), and Figure 4.10 (spectra 2 and 4)

- $\mathrm{Al}-\mathrm{O} \pm \mathrm{H}$ - Figure 4.6 (spectrum 1), Figure 4.7 (spectrum 3), Figure 4.9 (spectrum 2), Figure 4.10 (spectra 1 and 2), and Figure 4.11 (spectra 2)

- $\quad$ Ca-Al-O-C \pm H - Figure 4.8 (spectra 1 and 2)

- $\mathrm{Ca}-\mathrm{O} \pm \mathrm{C} \pm \mathrm{H}$ - Figure 4.11 (spectrum 1)

- $\mathrm{Ag}-\mathrm{Hg} \pm \mathrm{O} \pm \mathrm{H}$ - Figure 4.11 (spectrum 3) 


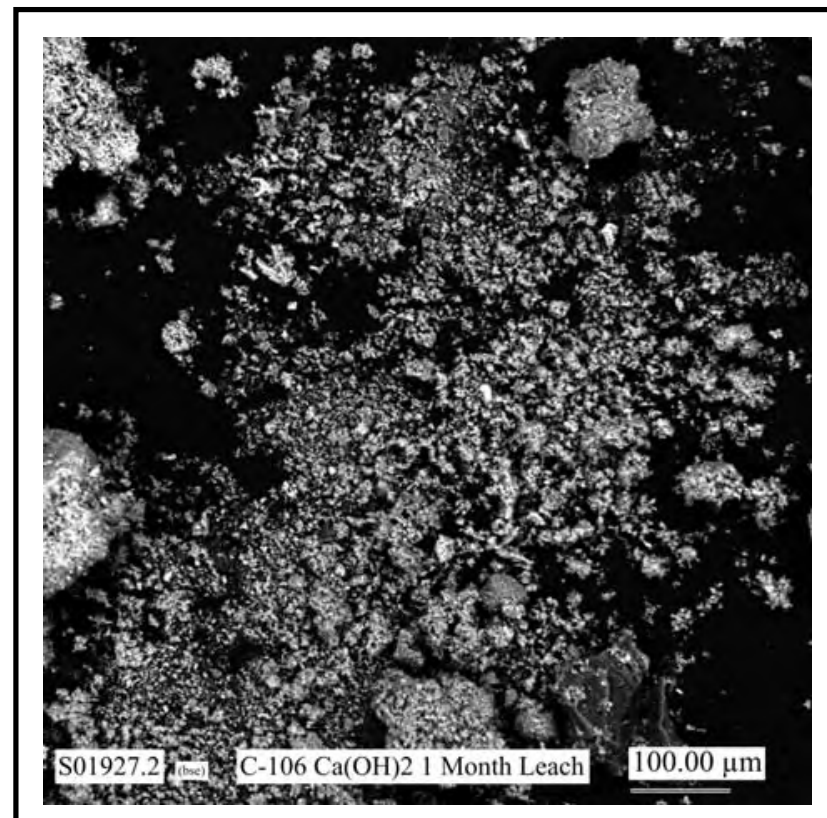

1-Month $\mathrm{Ca}(\mathrm{OH})_{2}$-Leached Sample

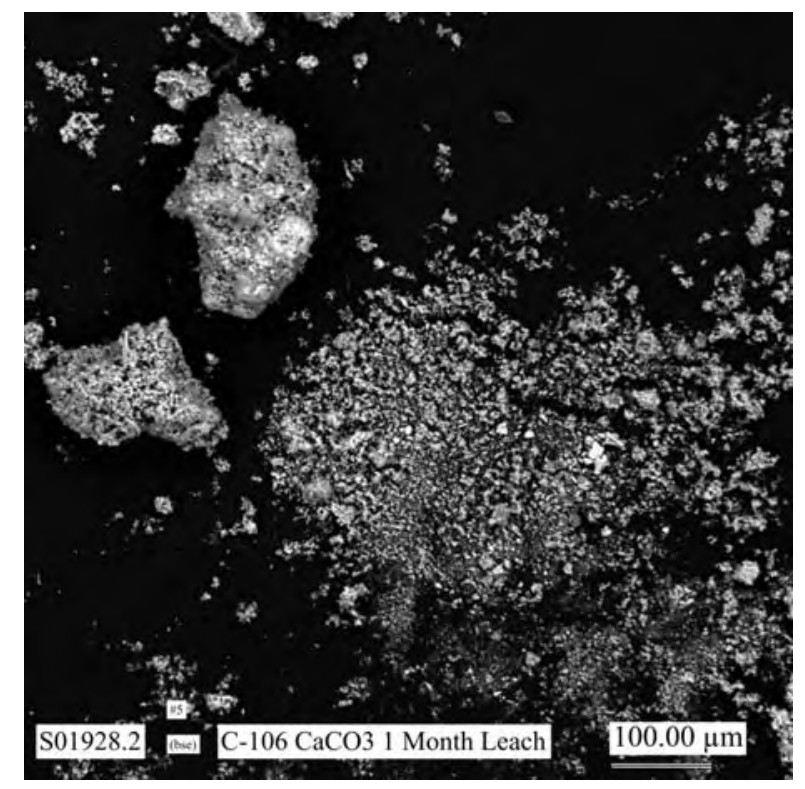

1-Month $\mathrm{CaCO}_{3}$-Leached Sample

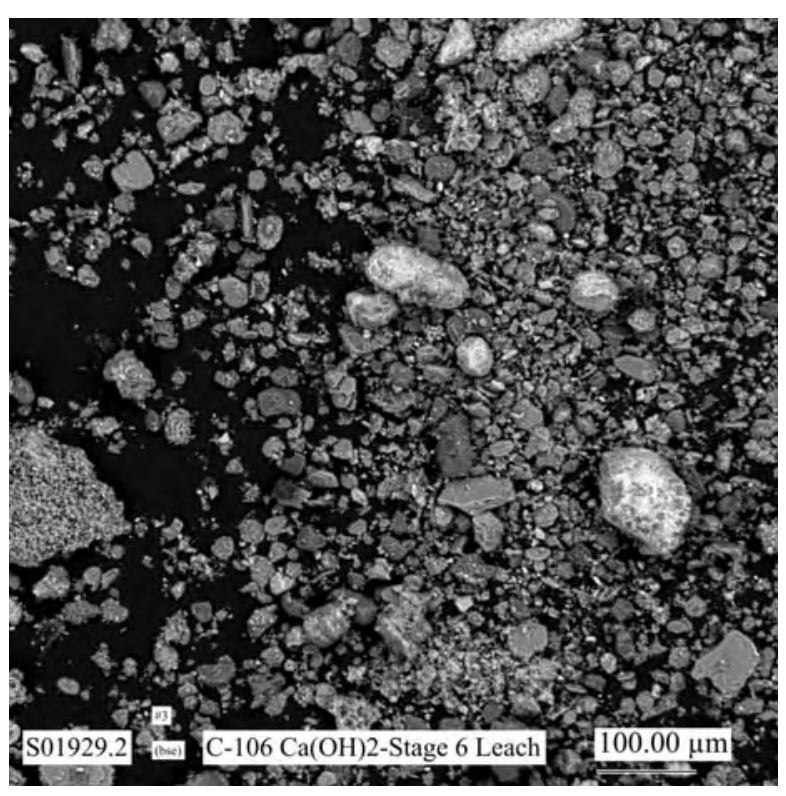

Stage 6 Sequential $\mathrm{Ca}(\mathrm{OH})_{2}$-Leached

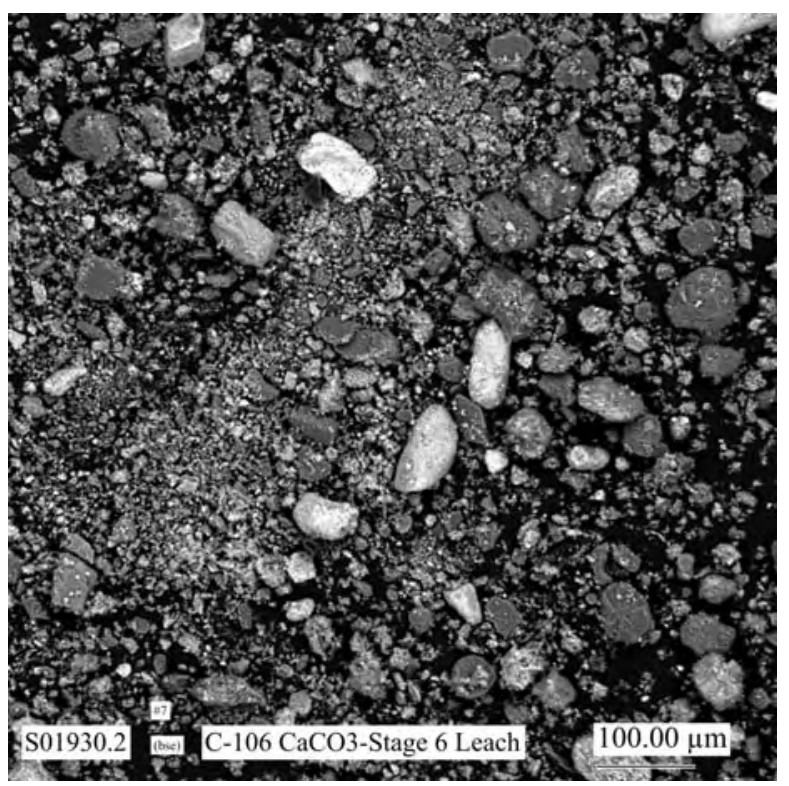

Stage 6 Sequential $\mathrm{CaCO}_{3}$-Leached Sample

Figure 4.4. Low Magnification SEM Micrographs of Particles Present in 1-Month and Stage 6 Sequential $\mathrm{Ca}(\mathrm{OH})_{2}$-Leached (left and right top row, respectively) and 1-Month and Stage 6 Sequential $\mathrm{CaCO}_{3}$-Leached (left and right bottom row, respectively) C-106 Residual Waste 


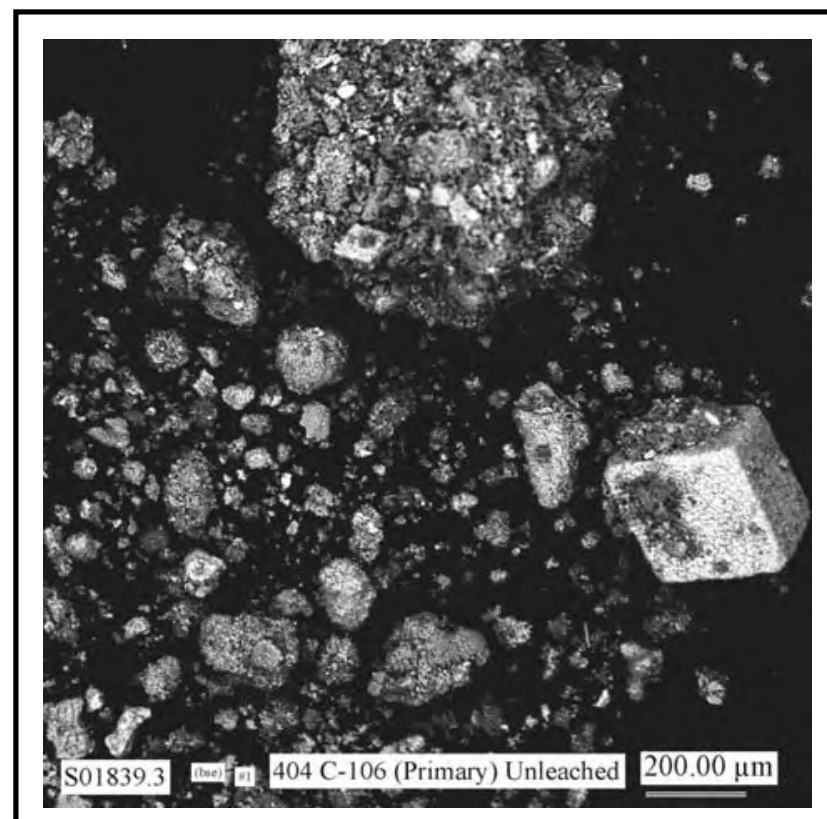

Unleached

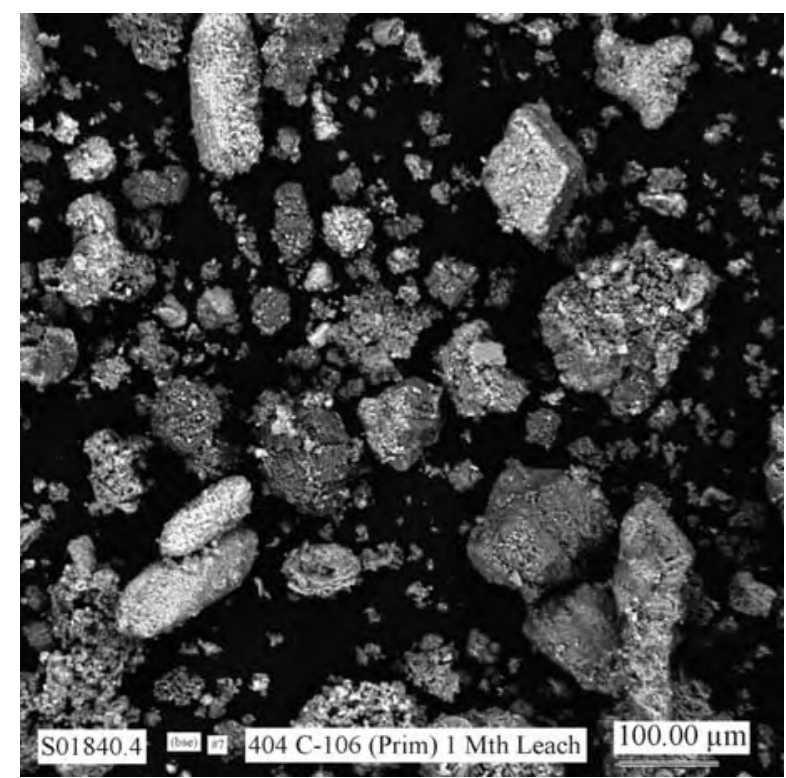

1-Month Water-Leached

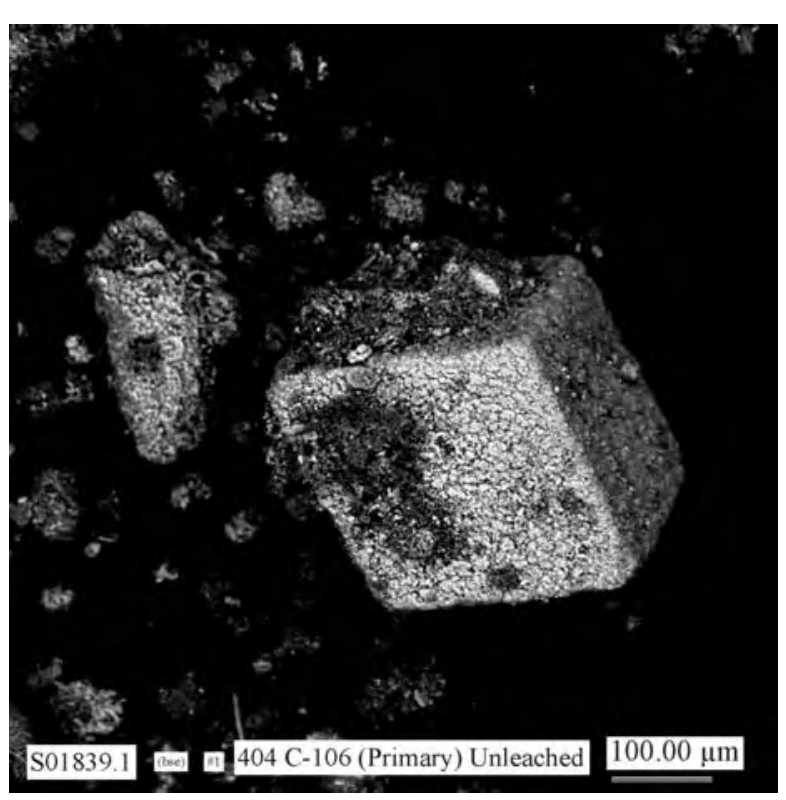

Unleached

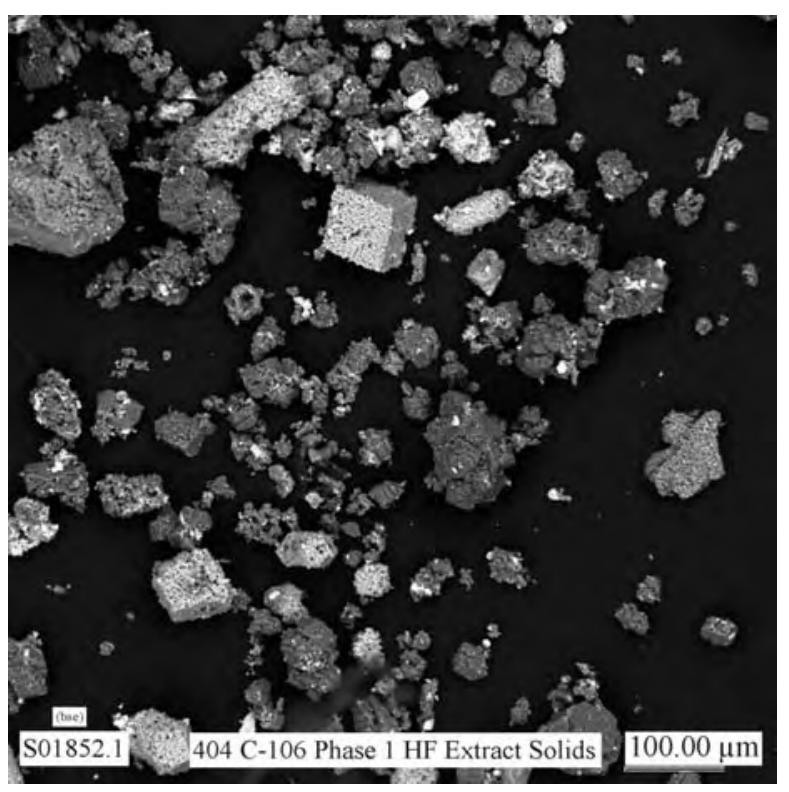

U HF Stage 1 Extract

Figure 4.5. Low Magnification SEM Micrographs of Particles Present in the Unleached (top row), 1-Month Water-Leached (left on bottom row), and HF Stage 1 Extract (right on bottom row) of Oxalic Acid-Treated Residual Waste from Tank C-106 (from Deutsch et al. 2005b) 


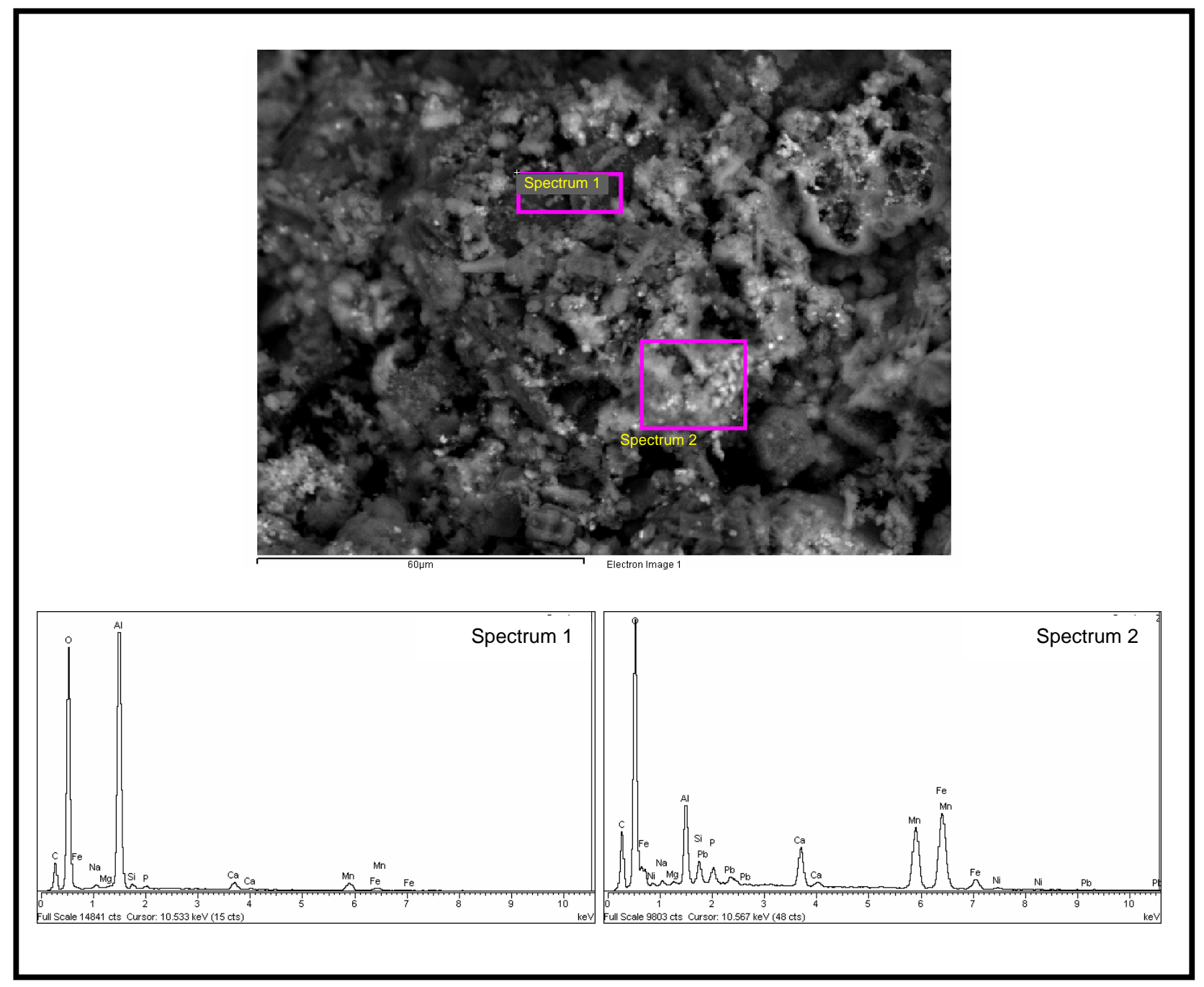

Figure 4.6. SEM Micrograph of Typical Particle Aggregates Present in 1-Month $\mathrm{Ca}(\mathrm{OH})_{2}$-Leached C-106 Residual Waste and Spectra for Areas Analyzed by EDS

The Ca-Mn-Al-Si-Fe- $\pm \mathrm{Pb} \pm \mathrm{REE}(\mathrm{Ce}) \pm \mathrm{Cr}$ (trace)-P-O $\pm \mathrm{C} \pm \mathrm{H}$ and $\mathrm{Al}-\mathrm{O} \pm \mathrm{H}$ were the most common phase compositions identified by EDS in the $\mathrm{Ca}(\mathrm{OH})_{2}$ - and $\mathrm{CaCO}_{3}$-leached samples. The Ca-Mn-Al-Si-Fe$\pm \mathrm{Pb} \pm \mathrm{REE}(\mathrm{Ce}) \pm \mathrm{Cr}$ (trace)-P-O $\pm \mathrm{C} \pm \mathrm{H}$ phase does not correspond to any phase identified by bulk XRD, and is compositionally different from the Mn-Al-Fe-Na-P-Si-Ca-O $\pm \mathrm{C} \pm \mathrm{H}$ phase identified by Deutsch et al. (2005b) in the unleached residual waste. In the $\mathrm{Ca}(\mathrm{OH})_{2}$ - and $\mathrm{CaCO}_{3}$-leached samples, Ca (based on EDS peak height) is usually the most or second most abundant element in these particles, whereas Mn and $\mathrm{Al}$ were the major components and $\mathrm{Ca}$ a minor component in the Mn-Al-Fe-Na-P-Si-Ca-O $\pm \mathrm{C} \pm \mathrm{H}$ phase found in the unleached residual solid. This phase in the $\mathrm{Ca}(\mathrm{OH})_{2}$ - and $\mathrm{CaCO}_{3}$-leached samples may also contain considerable concentrations of $\mathrm{Pb}$ (see spectra 3 and 4 in Figure 4.8) and/or trace concentrations of Ce (see spectrum 2 in Figure 4.10) and/or Cr. Because this phase is abundant in these leached samples and no compositionally similar phase was identified by bulk XRD, the Ca-Mn-Al-Si-Fe- $\pm \mathrm{Pb} \pm \mathrm{REE}(\mathrm{Ce}$ ) $\pm \mathrm{Cr}$ (trace)-P-O $\pm \mathrm{C} \pm \mathrm{H}$ phase is likely amorphous. Further analyses by transmission electron microscopy (TEM) or synchrotron-based $x$-ray microdiffraction $(\mu \mathrm{XRD})$ would be required to verify the amorphous nature of this phase and ascertain if this phase is a homogenous single phase. 


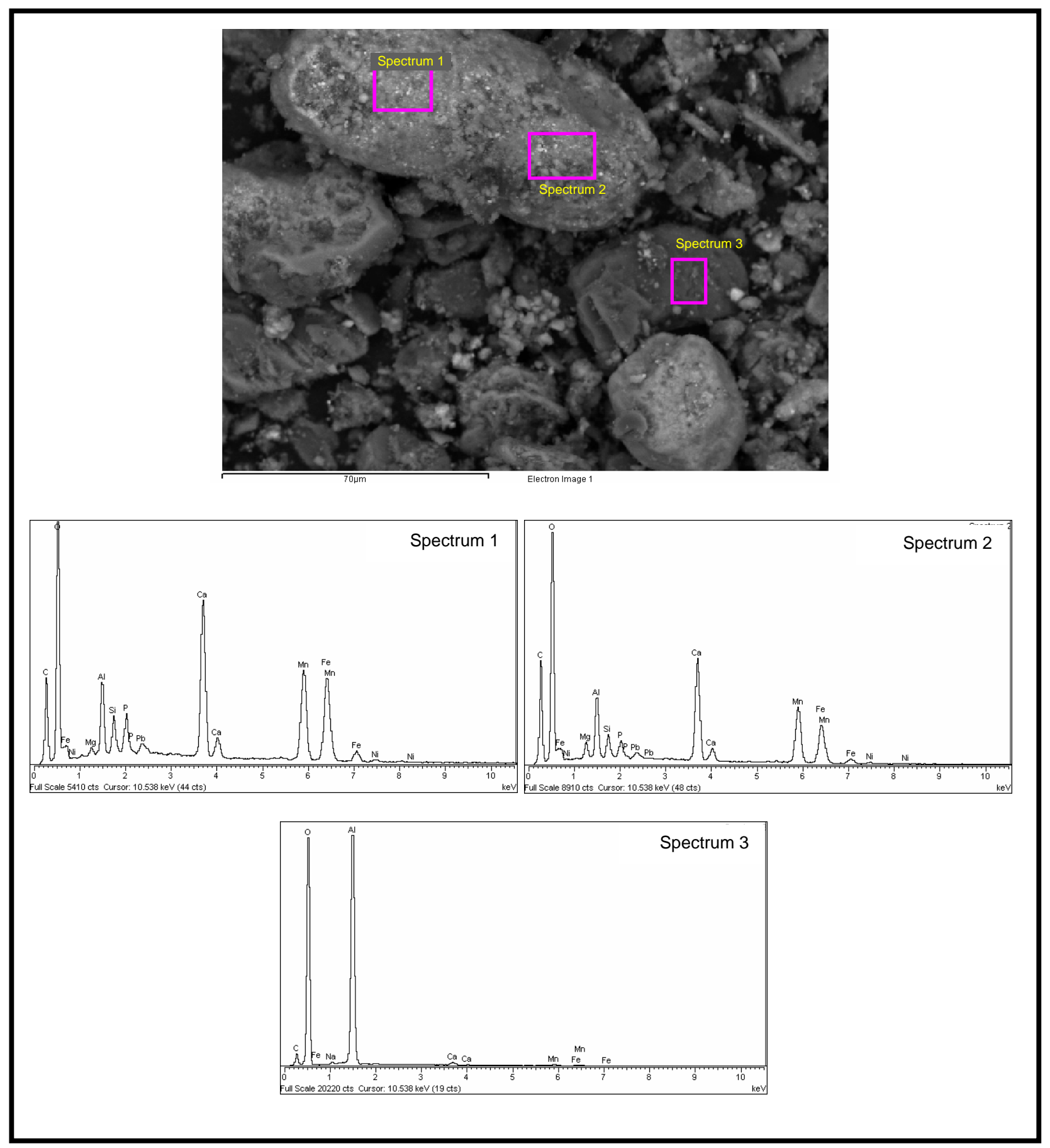

Figure 4.7. SEM Micrograph of Typical Particles Present in Stage 6 Sequential Ca(OH) $)_{2}-\mathrm{Leached} \mathrm{C-106}$ Residual Waste and Spectra for Areas Analyzed by EDS 


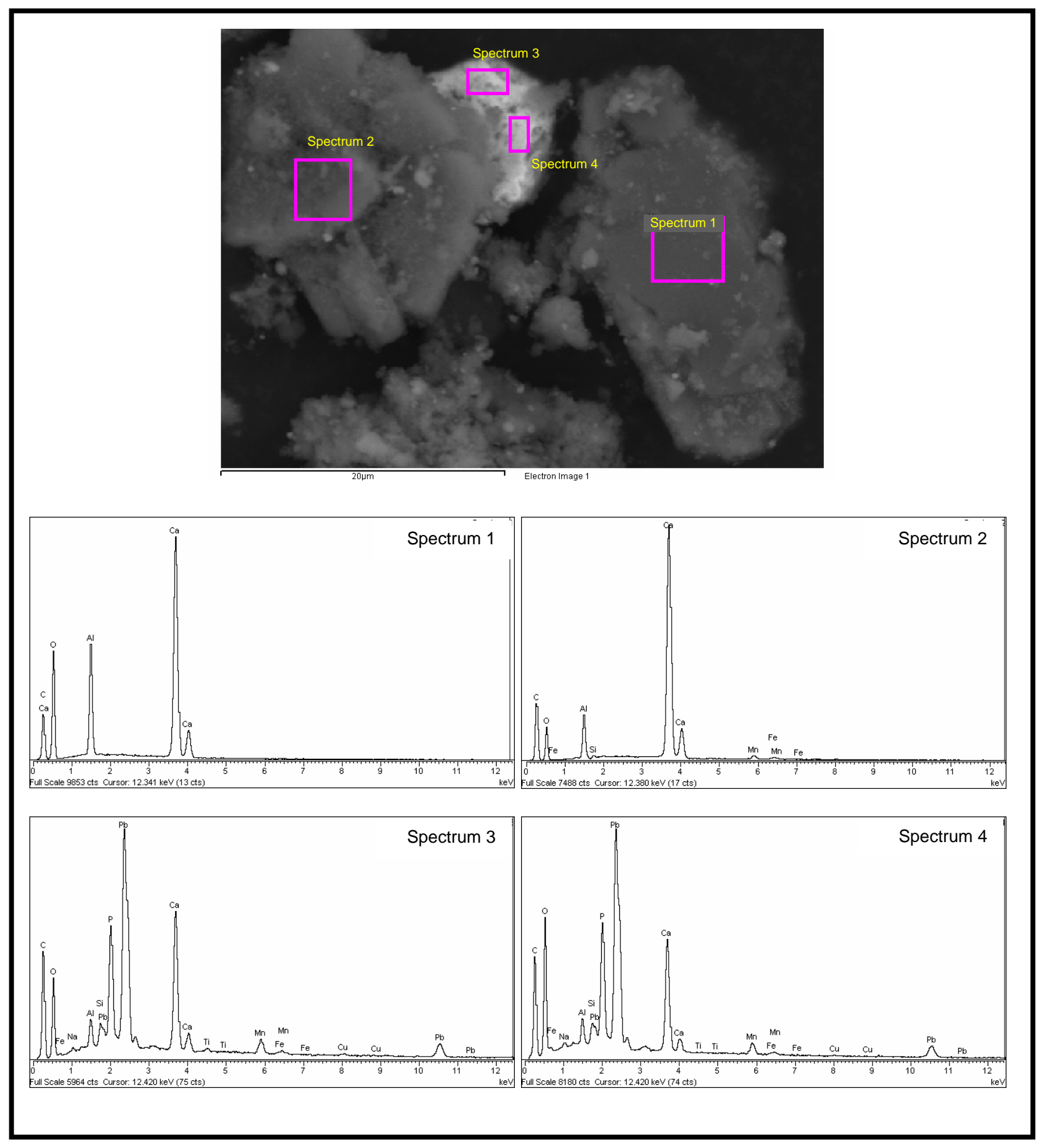

Figure 4.8. SEM Micrograph of Typical Particles Present in Stage 6 Sequential $\mathrm{Ca}(\mathrm{OH})_{2}$-Leached C-106 Residual Waste and Spectra for Areas Analyzed by EDS 


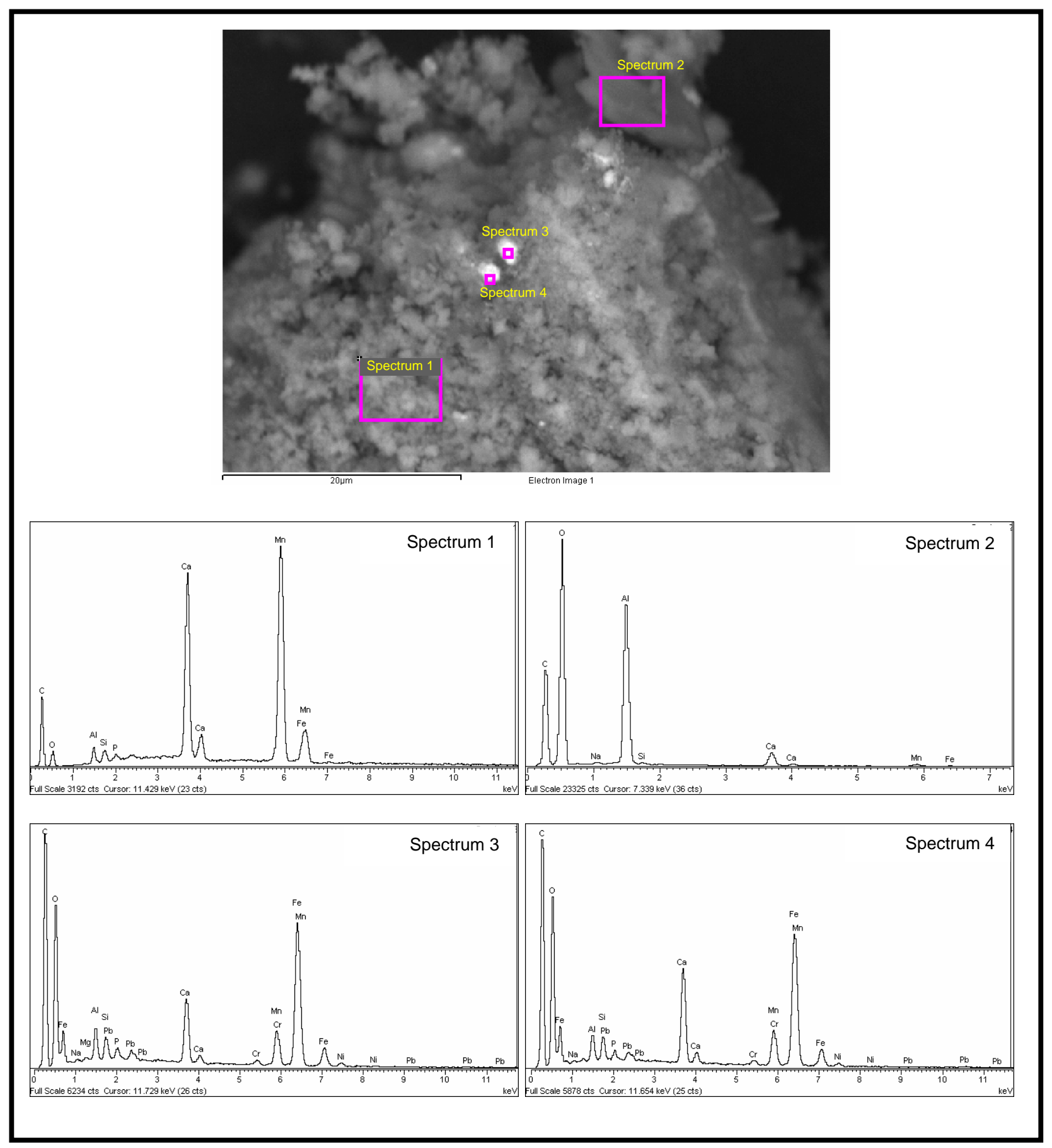

Figure 4.9. SEM Micrograph of Typical Particles Present in 1-Month $\mathrm{CaCO}_{3}$-Leached C-106 Residual Waste and Spectra for Areas Analyzed by EDS 


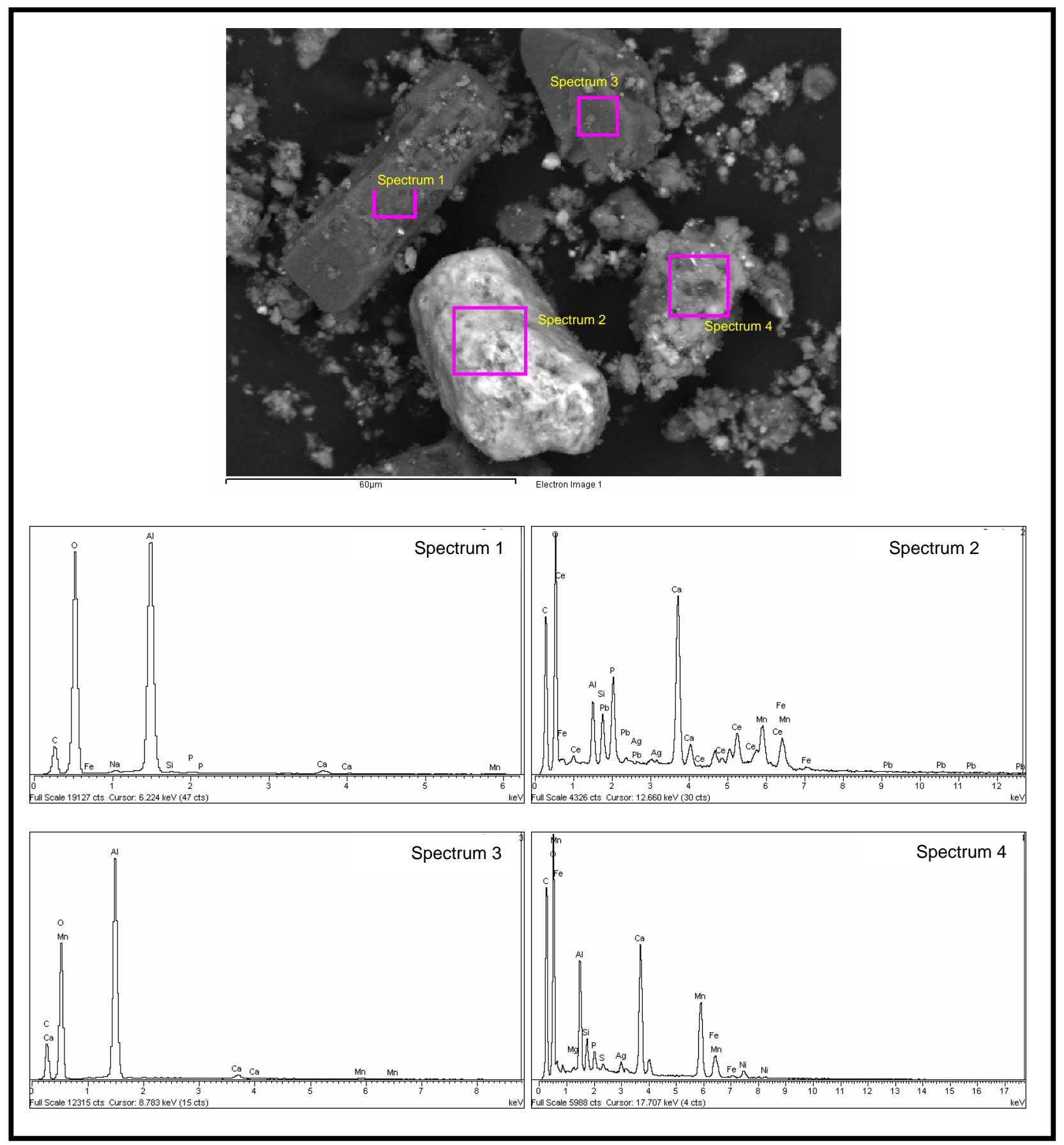

Figure 4.10. SEM Micrograph of Typical Particles Present in Stage 6 Sequential $\mathrm{CaCO}_{3}$-Leached C-106 Residual Waste and Spectra for Areas Analyzed by EDS (Also see colorized and blackand-white element distribution maps in Figures 4.19 and 4.20.) 


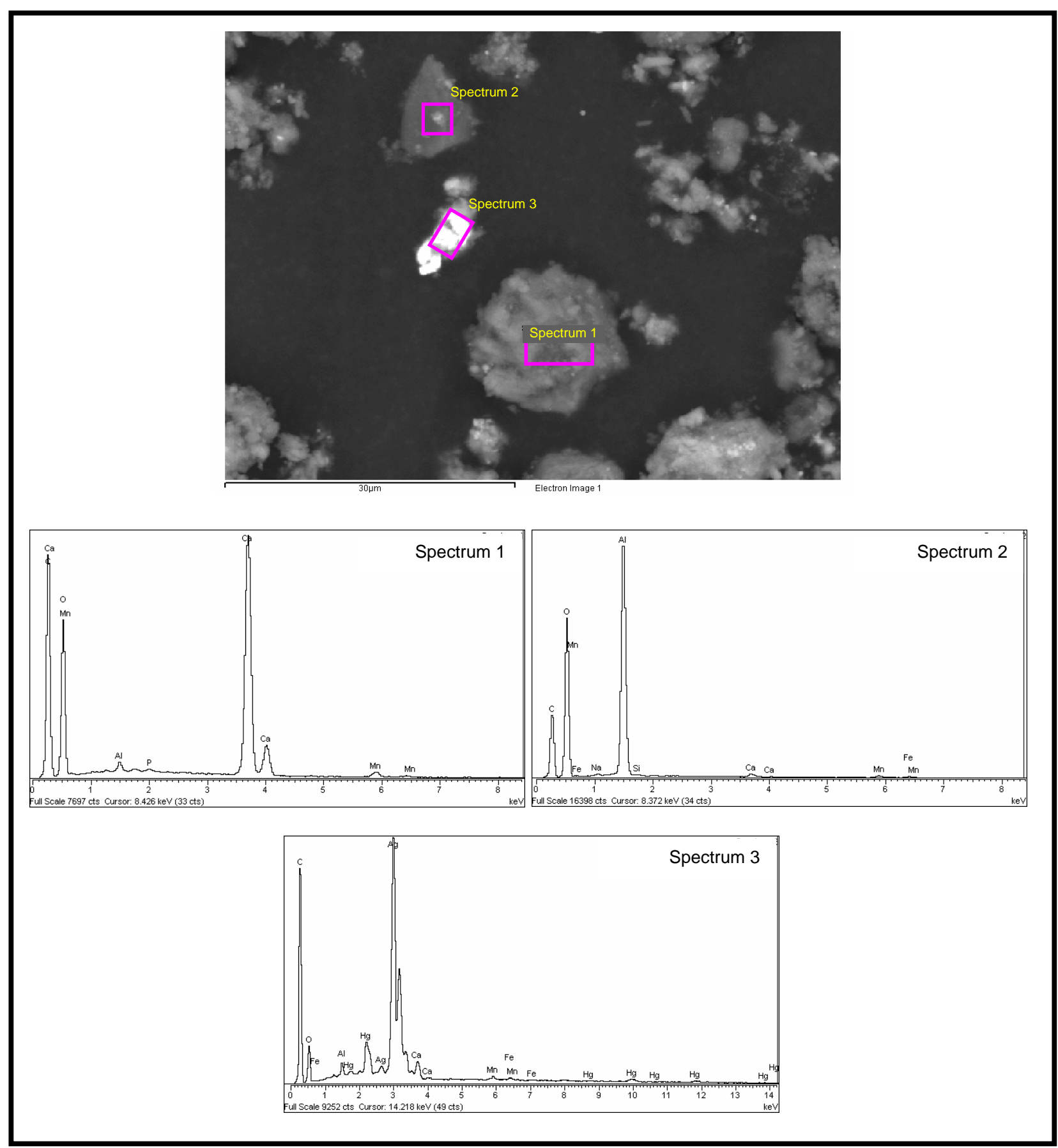

Figure 4.11. SEM Micrograph of Typical Particles Present in Stage 6 Sequential $\mathrm{CaCO}_{3}$-Leached C-106 Residual Waste and Spectra for Areas Analyzed by EDS 
The $\mathrm{Al}-\mathrm{O} \pm \mathrm{H}$ and $\mathrm{Ca}-\mathrm{O} \pm \mathrm{C} \pm \mathrm{H}$ phases also exist in the unleached residual waste studied by Deutsch et al. (2005b). The Al-O $\pm \mathrm{H}$ phase likely corresponds to gibbsite and/or böhmite which were identified by bulk XRD. The $\mathrm{Ca}-\mathrm{O} \pm \mathrm{C} \pm \mathrm{H}$ phases probably correspond to either calcite or whewellite, which were also detected by bulk XRD.

The 1-month $\mathrm{Ca}(\mathrm{OH})_{2}$ - and 1-month and Stage 6 sequential $\mathrm{CaCO}_{3}$-leached samples also contain another phase not previously identified by bulk XRD in these or the unleached residual waste samples. This phase consists of $\mathrm{Ca}-\mathrm{Al}-\mathrm{O} \pm \mathrm{C} \pm \mathrm{H}$ (spectra 1 and 2 in Figure 4.8). Based on a search of mineral composition databases on the Internet, the only phases found that match this composition include alumohydrocalcite $\left[\mathrm{CaAl}_{2}\left(\mathrm{CO}_{3}\right)_{2}(\mathrm{OH})_{4} \cdot 3 \mathrm{H}_{2} \mathrm{O}\right]$ and paraalumohydrocalcite $\left[\mathrm{CaAl}_{2}\left(\mathrm{CO}_{3}\right)_{2}(\mathrm{OH})_{4} \cdot 6 \mathrm{H}_{2} \mathrm{O}\right]$. Also, a search of the PDF XRD mineral and inorganic solid database files for this composition or any similar oxides, hydroxides, or carbonates did not identify any phase with an XRD pattern that is consistent with the bulk XRD patterns for these samples. Moreover, as noted in Section 4.4, the measured XRD patterns did not contain any unassigned reflections. This suggests that all crystalline phases present at greater than 5 to $10 \mathrm{wt} \%$ in these $\mathrm{Ca}(\mathrm{OH})_{2}$ - and $\mathrm{CaCO}_{3}$-leached residual waste samples were identified. Therefore, the $\mathrm{Ca}-\mathrm{Al}-\mathrm{O} \pm \mathrm{C} \pm \mathrm{H}$ phase may be present in the leached samples at less than $5-10 \mathrm{wt} \%$ or be amorphous. Additional analyses by TEM or synchrotron-based $\mu \mathrm{XRD}$ would be required to help identify this phase.

The SEM micrographs of the $\mathrm{Ca}(\mathrm{OH})_{2}$ - and $\mathrm{CaCO}_{3}$-leached samples sometimes contained bright (white) particles or aggregates (see particles marked by spectrum 3 in Figure 4.11) a few micrometers to submicrometer in size that contained primarily Ag, Hg, O, and possibly C. These Ag-Hg particles were not as common or large in these samples as those identified by Deutsch et al. (2005a) in the unleached, water-leached, and HF-extracted residual waste samples.

One particle cluster with composition $\mathrm{Mn}-\mathrm{Na}-\mathrm{P}-\mathrm{O} \pm \mathrm{C} \pm \mathrm{H}$ was also observed (see Figure B.24 in Appendix B) in the 1-month $\mathrm{Ca}(\mathrm{OH})_{2}$-leached sample. This particle composition was not observed in any of the other leached samples analyzed by SEM/EDS. However, given the fine-grained nature of the particle aggregates in these samples, particles with this composition might be present elsewhere and not identified by EDS analyses, which often represented a composite composition of aggregates of several micrometer-size particles. Based on a search of mineral composition databases on the Internet, the composition Mn-Na-P-O $\pm \mathrm{C} \pm \mathrm{H}$ could correspond to minerals such as kanonerovite $\left(\mathrm{MnNa}_{3} \mathrm{P}_{3} \mathrm{O}_{10} \cdot 12 \mathrm{H}_{2} \mathrm{O}\right)$, natrophilite $\left(\mathrm{NaMnPO}_{4}\right)$, sidorenkite $\left[\mathrm{Na}_{3} \mathrm{Mn}\left(\mathrm{PO}_{4}\right)\left(\mathrm{CO}_{3}\right)\right]$, and viitaniemiite $\left[\mathrm{Na}(\mathrm{Ca}, \mathrm{Mn}) \mathrm{Al}\left(\mathrm{PO}_{4}\right)(\mathrm{F}, \mathrm{OH})_{3}\right]$. No efforts were made to review the literature and determine if the conditions of formation for these minerals correspond to those associated with residual waste from tank C-106. However, Bechtold et al. (2003) reported the possible presence of sidorenkite in a baseline sample of C-106 sludge based on characterization by XRD and SEM/EDS.

Compared to the SEM/EDS results for the unleached residual solid presented by Deutsch et al. (2005a), SEM/EDS analyses of the $\mathrm{Ca}(\mathrm{OH})_{2}$ - and $\mathrm{CaCO}_{3}$-leached samples did not indicate the presence of any obvious extensive coatings of newly precipitated phases on the particles and aggregates in the C-106 residual waste. If coatings existed that were only one or 2 micrometers thick, then EDS of such coatings would be difficult since the measured composition would be a composite of the coating and phase(s) under the coating.

The EDS analyses of the $\mathrm{Ca}(\mathrm{OH})_{2}$ - and $\mathrm{CaCO}_{3}$-leached samples did not find any particles or aggregates with compositions corresponding to the $\mathrm{Mn}-\mathrm{O}-\mathrm{C} \pm \mathrm{H}, \mathrm{Al}-\mathrm{Na}-\mathrm{O}-\mathrm{C} \pm \mathrm{H}, \mathrm{Fe}-\mathrm{Cr}-\mathrm{O} \pm \mathrm{C} \pm \mathrm{H}$, and 
Fe-Mn-O $\pm \mathrm{C} \pm \mathrm{H}$ phases observed by SEM/EDS in the samples of C-106 residual waste analyzed by Deutsch et al. (2005a). The Fe-Cr and Fe-Mn oxide phases were not common in the samples of C-106 residual waste analyzed by Deutsch et al. (2005b), but were nonetheless observed by SEM/EDS. Although Fe was detected by EDS in the Ca-Mn-Al-Si-Fe- $\pm \mathrm{Pb} \pm \mathrm{REE}(\mathrm{Ce}) \pm \mathrm{Cr}$ (trace)-P-O $\pm \mathrm{C} \pm \mathrm{H}$ phase and possibly enriched in areas in some particles at the submicrometer scale (see EDS element maps discussed later in this section), no distinct Fe-Cr or Fe-Mn oxide phases were identified by EDS or bulk XRD in the $\mathrm{Ca}(\mathrm{OH})_{2}$ - and $\mathrm{Ca}(\mathrm{OH})_{2} / \mathrm{CaCO}_{3}$-leached samples.

The SEM/EDS analyses did not indicate the presence of I, Tc, or U in any particles or aggregates present in the $\mathrm{Ca}(\mathrm{OH})_{2}$ - and $\mathrm{CaCO}_{3}$-leached samples. This was due to their low concentrations in these residual waste samples and the high detection limits for analysis by EDS.

Colorized and black-and-white element distribution maps were also recorded for particles and aggregates present in the 1-month (Figure 4.12 and Figure 4.13) and Stage 6 sequential (Figure 4.14, Figure 4.15, and Figure 4.16) $\mathrm{Ca}(\mathrm{OH})_{2}$-leached, and in 1-month (Figure 4.17 and Figure 4.18) and Stage 6 sequential (Figure 4.19 and Figure 4.20) $\mathrm{CaCO}_{3}$-leached samples. The BSE SEM micrographs at the top of Figure 4.12 through Figure 4.20 show the particles included in the element distribution maps given in each figure. For the colorized element distribution maps, keys are given in each figure to indicate which elements correspond to each color. For the black-and-white element distribution maps, the concentration of each listed element is directly proportional to the regions of brightness (i.e., brighter the area, the higher the concentration of that element) in the corresponding distribution map.

The element distribution maps (Figure 4.14 through Figure 4.20) clearly show the complexity of the compositions of phases, especially for the mineral aggregates, in the $\mathrm{Ca}(\mathrm{OH})_{2}$ - and $\mathrm{CaCO}_{3}$-leached samples. Like the EDS spectra in Figure 4.6 through Figure 4.11 and Appendices B through E, the element distribution maps illustrate the importance of $\mathrm{Mn}$, $\mathrm{Ca}$, and $\mathrm{Al}$ with respect to the particle compositions and bulk chemistry of these $\mathrm{Ca}(\mathrm{OH})_{2}$ - and $\mathrm{CaCO}_{3}$-leached samples. Although the importance of $\mathrm{Mn}$ and $\mathrm{Al}$ in C-106 residual waste solids was previously shown in the SEM/EDS results in Deutsch et al. (2005a) and EDS element distribution maps in Deutsch et al. (2005b), the SEM/EDS results in this report, such as Figure 4.14 through Figure 4.20, suggest that the Ca concentrations have increased in the $\mathrm{Ca}(\mathrm{OH})_{2}$ - and $\mathrm{CaCO}_{3}$-leached solid samples relative to the unleached residual waste from tank C-106. This includes the increase in Ca concentration detected by EDS in the Ca-Mn-Al-Si-Fe- $\pm \mathrm{Pb} \pm \mathrm{REE}(\mathrm{Ce}$ ) $\pm \mathrm{Cr}$ (trace)-P-O $\pm \mathrm{C} \pm \mathrm{H}$ solids which are common in these leached materials and the identification by EDS of a Ca-Al-O-C $\pm \mathrm{H}$ phase, which was not previously observed in the unleached C-106 residual waste. 


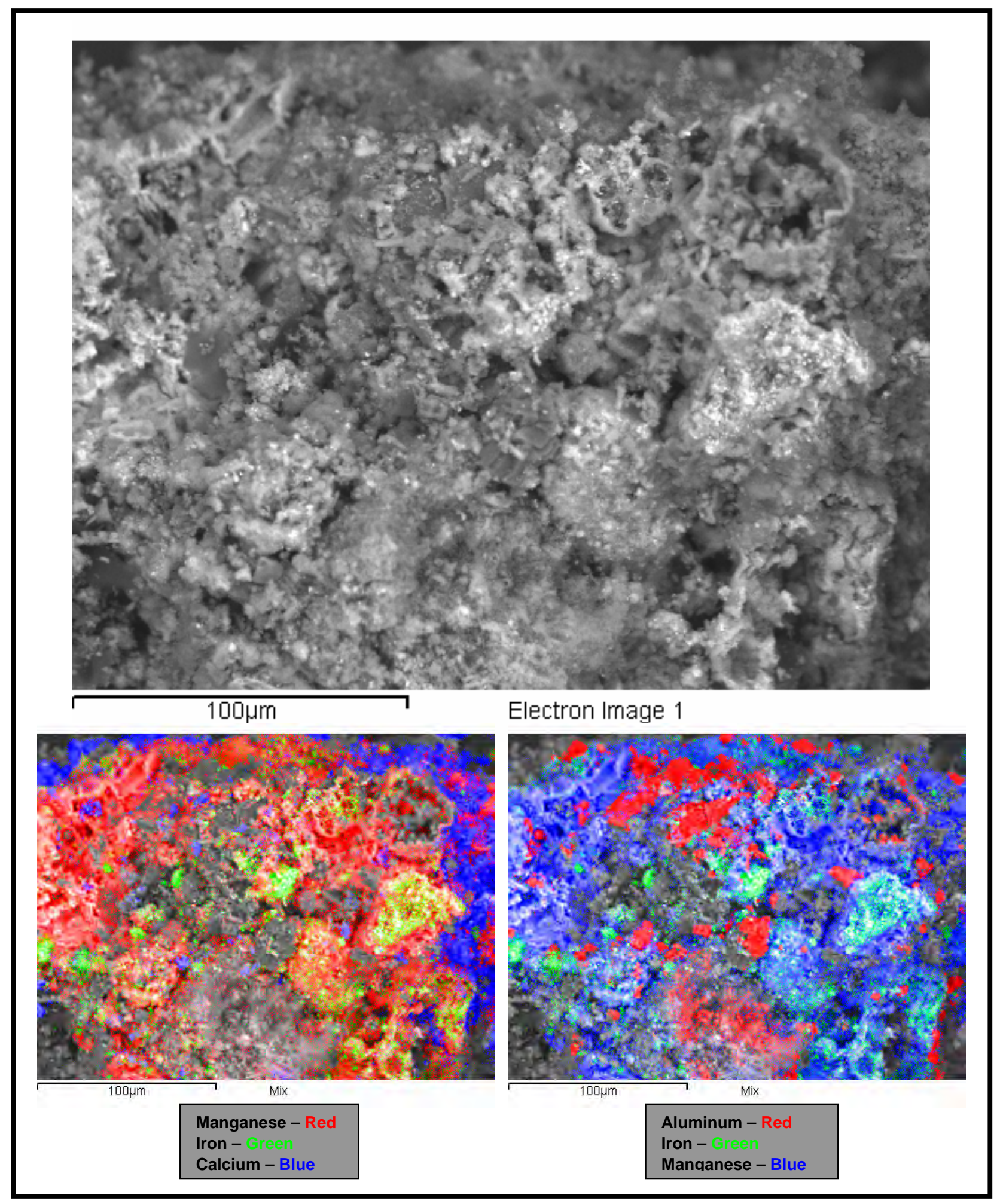

Figure 4.12. Backscatter-Electron SEM Image and Colorized Element Maps for a Particle Aggregate from the 1-Month $\mathrm{Ca}(\mathrm{OH})_{2}$-Leached C-106 Residual Waste 


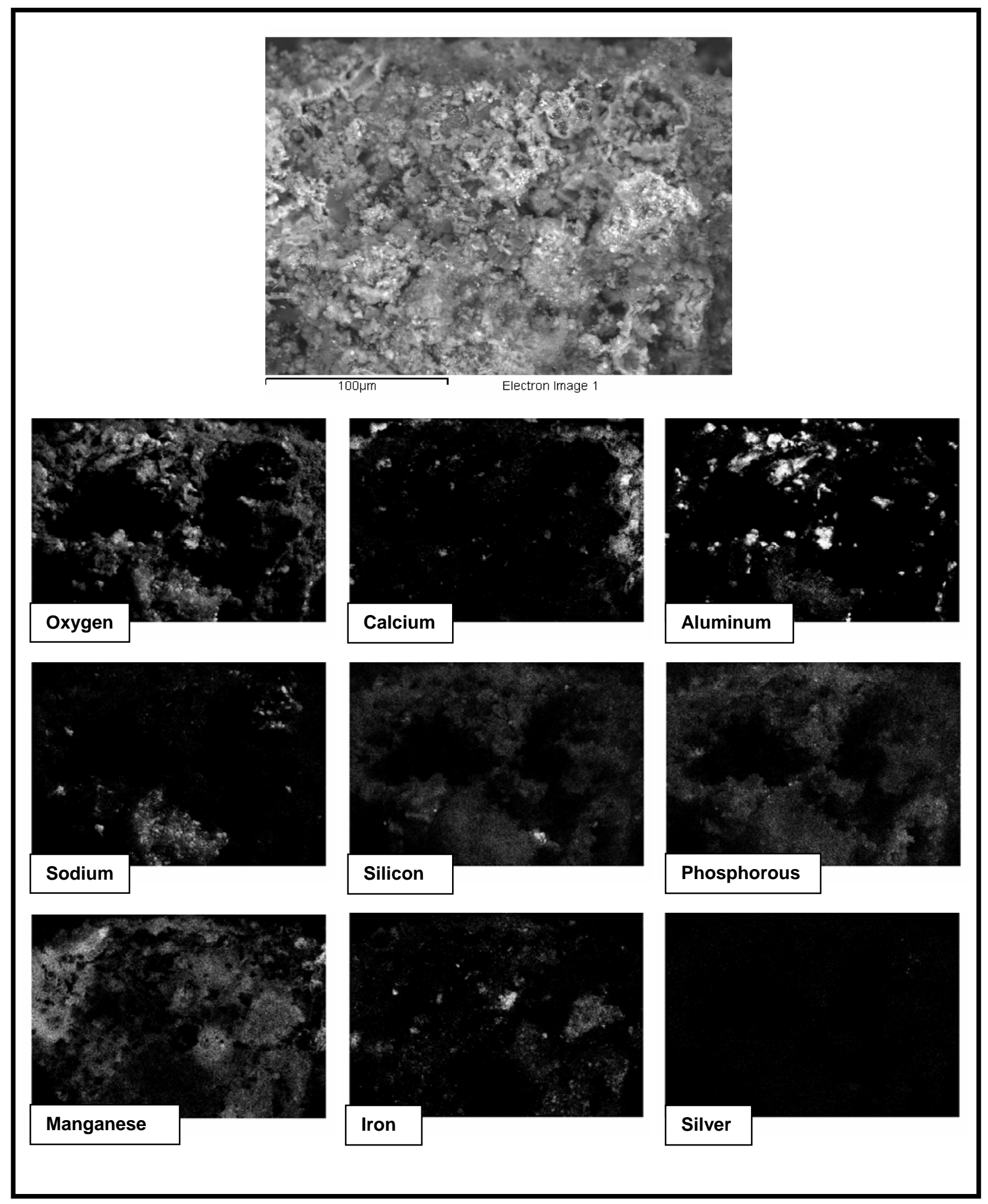

Figure 4.13. Backscatter-Electron SEM Micrograph and Element Distribution Maps for Particles in 1-Month $\mathrm{Ca}(\mathrm{OH})_{2}$-Leached C-106 Residual Waste 


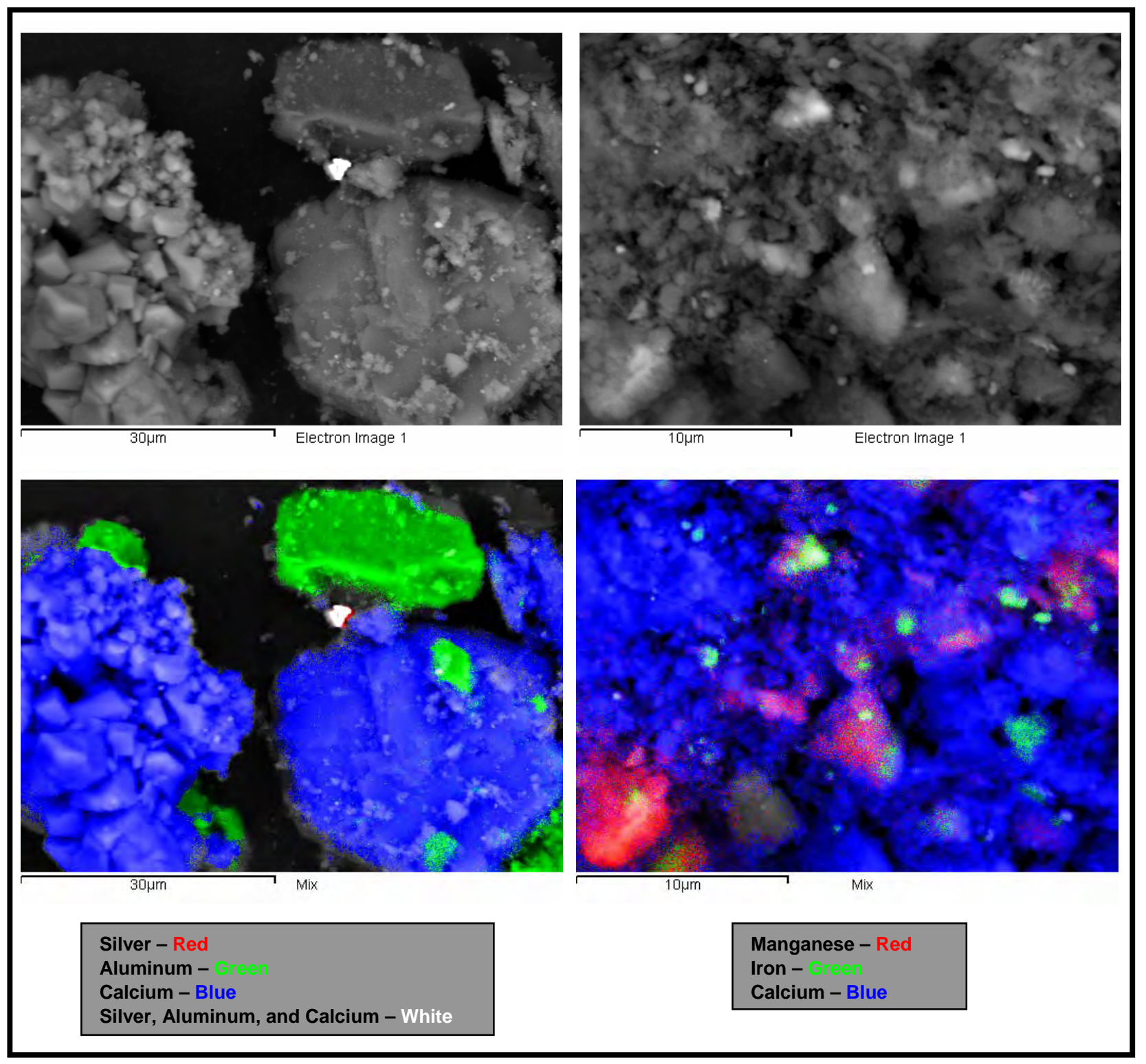

Figure 4.14. Backscatter-Electron SEM Image and Colorized Element Maps for a Particle Aggregate from the Stage 6 Sequential $\mathrm{Ca}(\mathrm{OH})_{2}$-Leached C-106 Residual Waste 


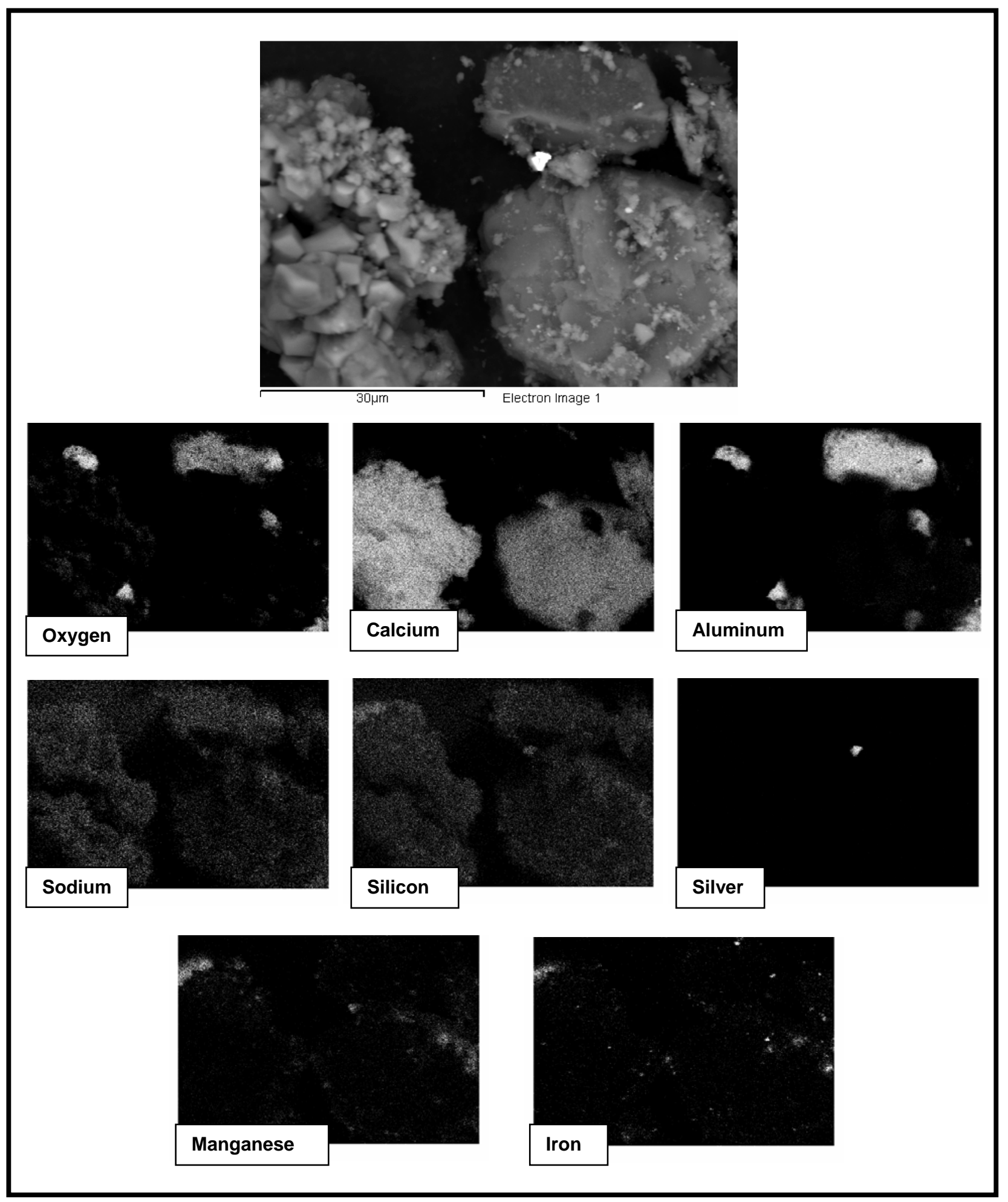

Figure 4.15. Backscatter-Electron SEM Micrograph and Element Distribution Maps for Particles in Stage 6 Sequential $\mathrm{Ca}(\mathrm{OH})_{2}$-Leached C-106 Residual Waste 


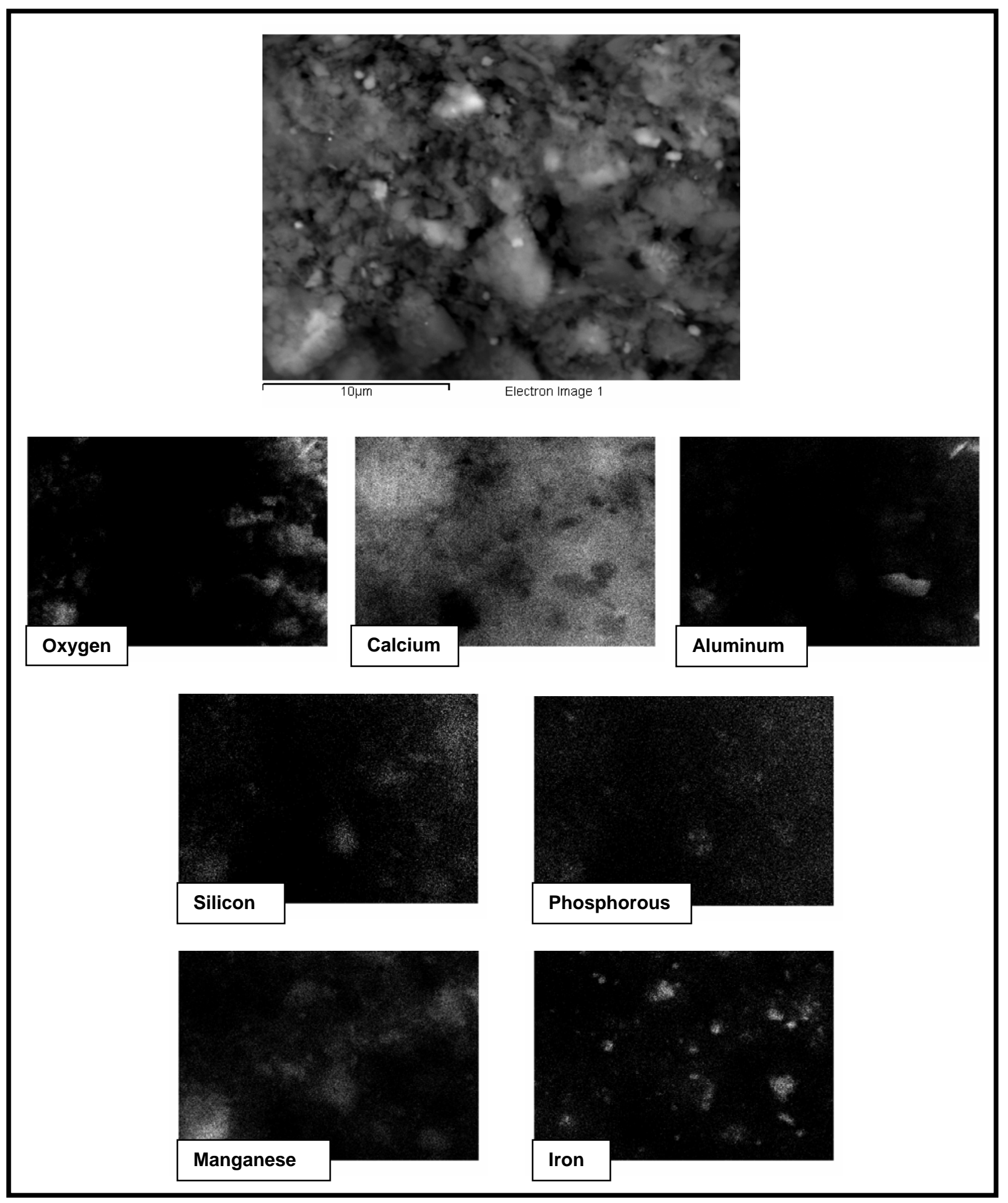

Figure 4.16. Backscatter-Electron SEM Micrograph and Element Distribution Maps for Particles in Stage 6 Sequential $\mathrm{Ca}(\mathrm{OH})_{2}$-Leached C-106 Residual Waste 


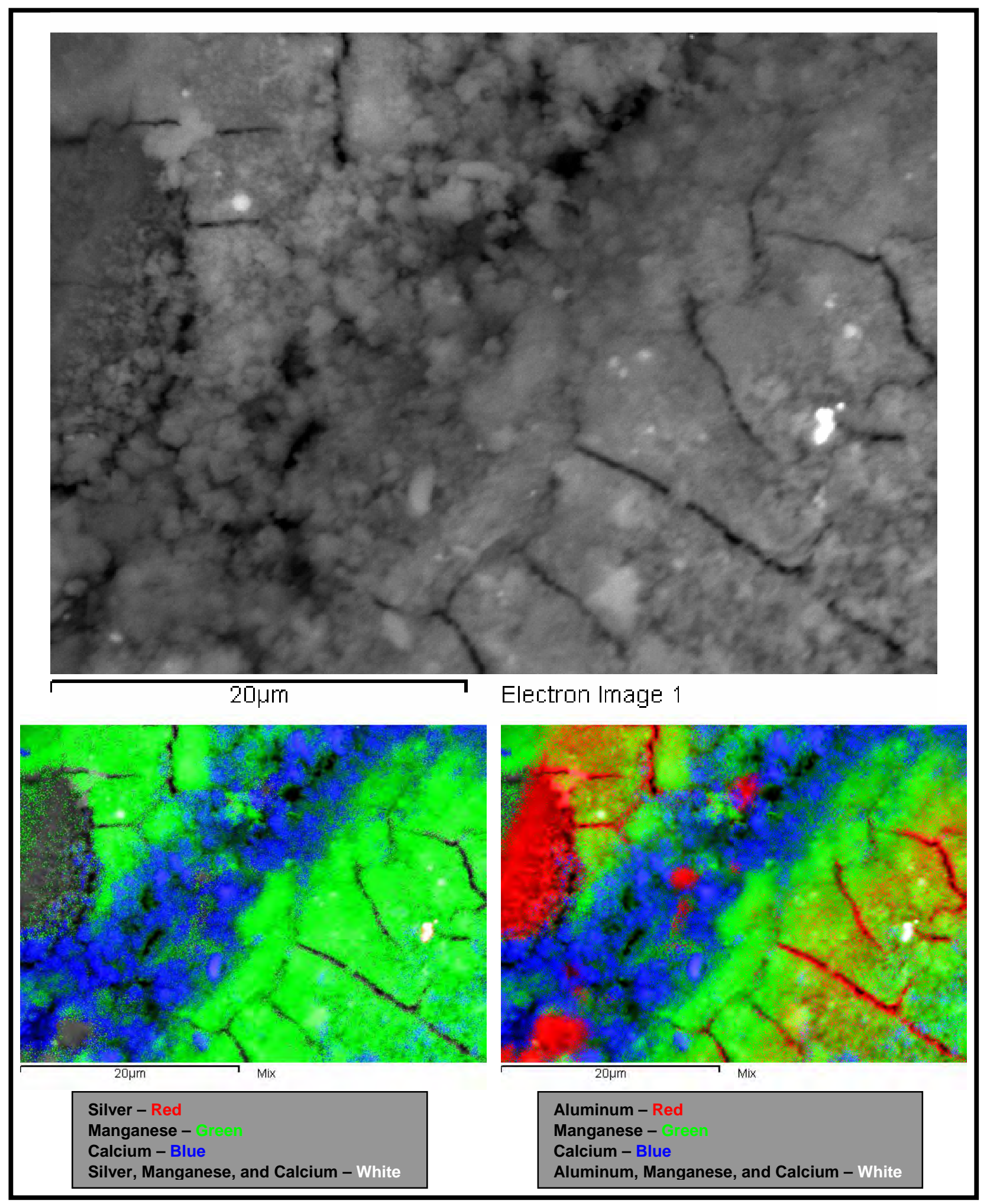

Figure 4.17. Backscatter-Electron SEM Image and Colorized Element Maps for a Particle Aggregate from the 1-Month $\mathrm{CaCO}_{3}$-Leached C-106 Residual Waste 


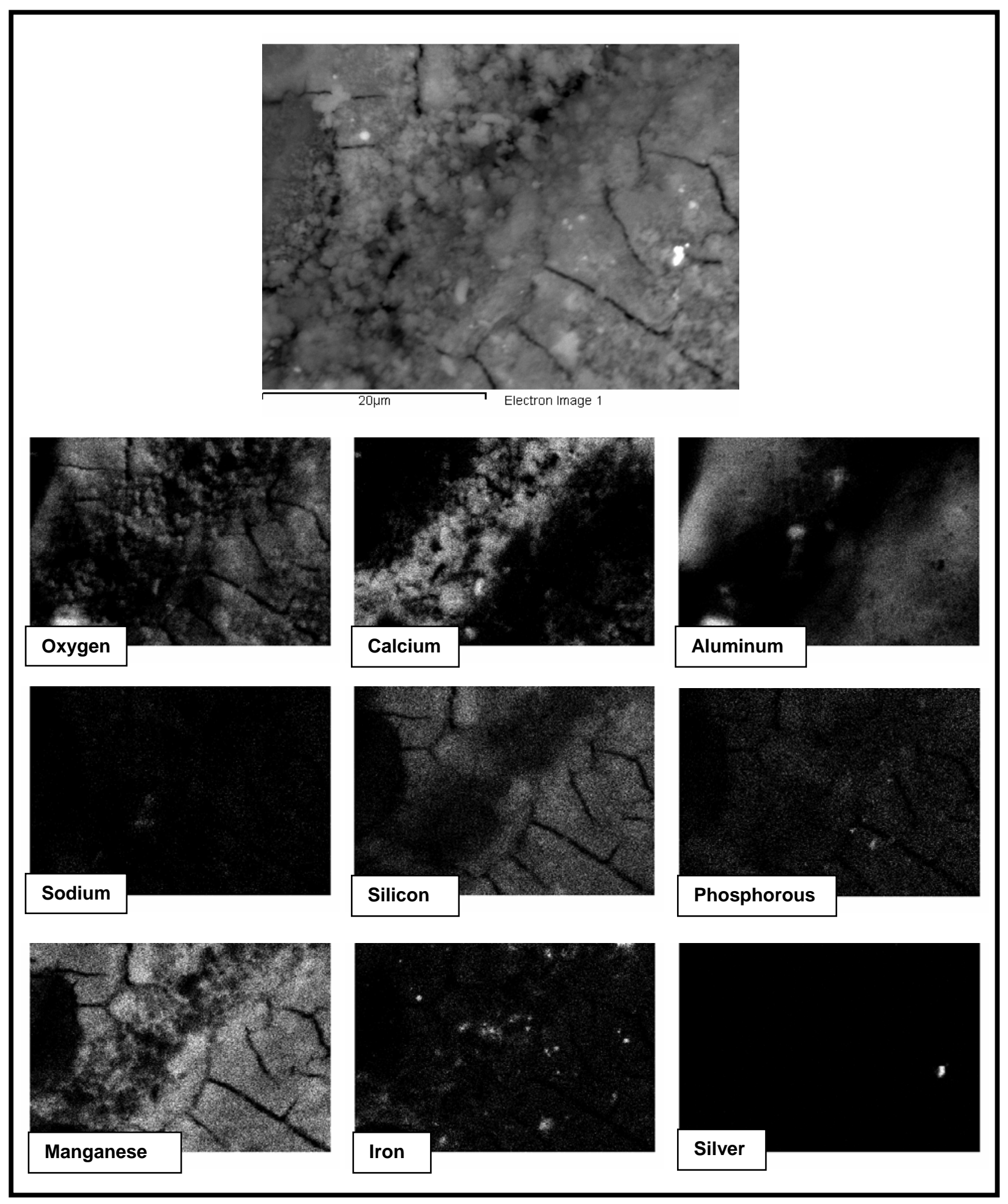

Figure 4.18. Backscatter-Electron SEM Micrograph and Element Distribution Maps for Particles in 1-Month $\mathrm{CaCO}_{3}$-Leached C-106 Residual Waste 

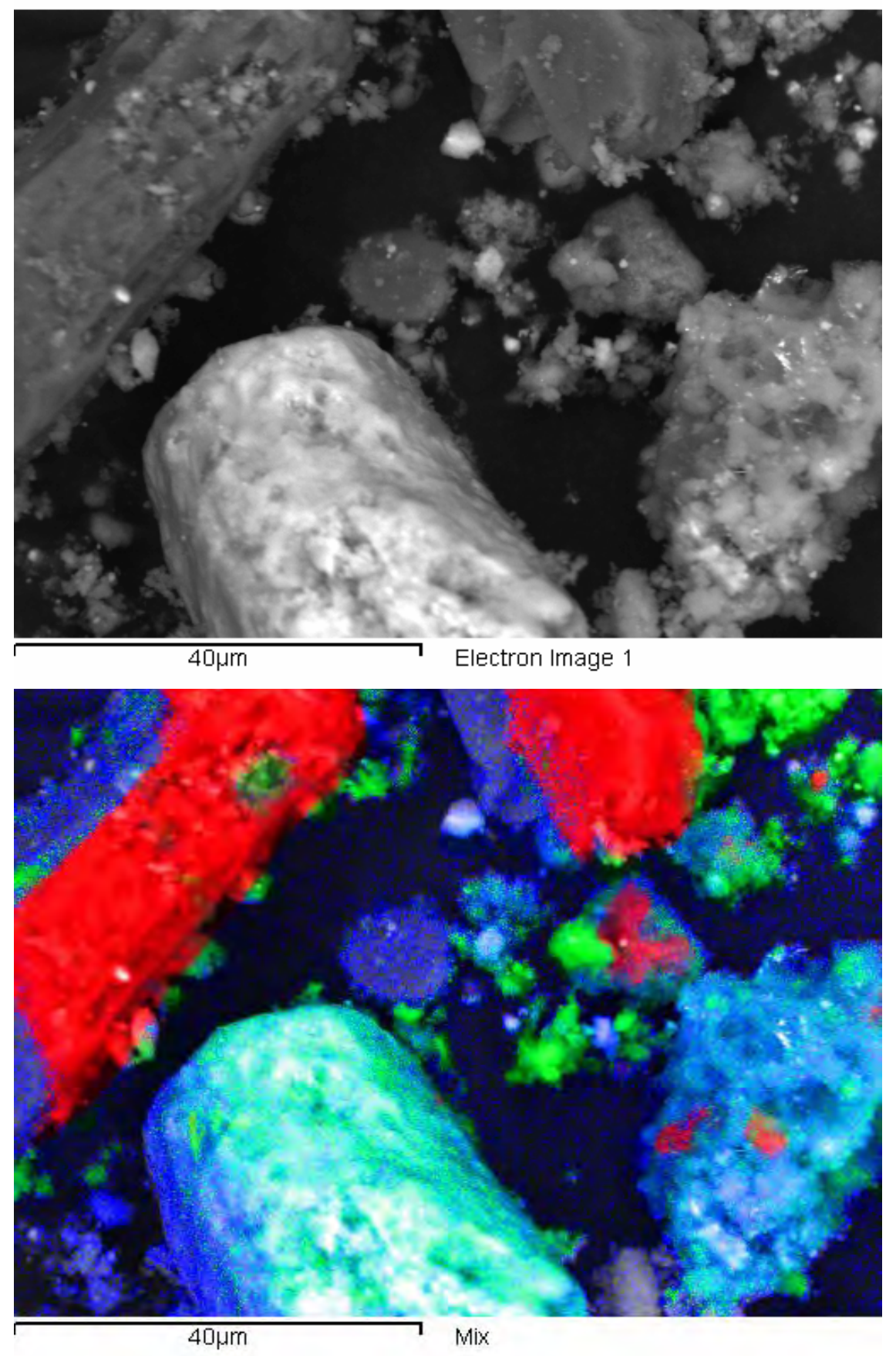

Aluminum - Red

Manganese -

Calcium - Blue

Figure 4.19. Backscatter-Electron SEM Image and a Colorized Element Map for a Particle Aggregate from the Stage 6 Sequential $\mathrm{CaCO}_{3}$-Leached C-106 Residual Waste 


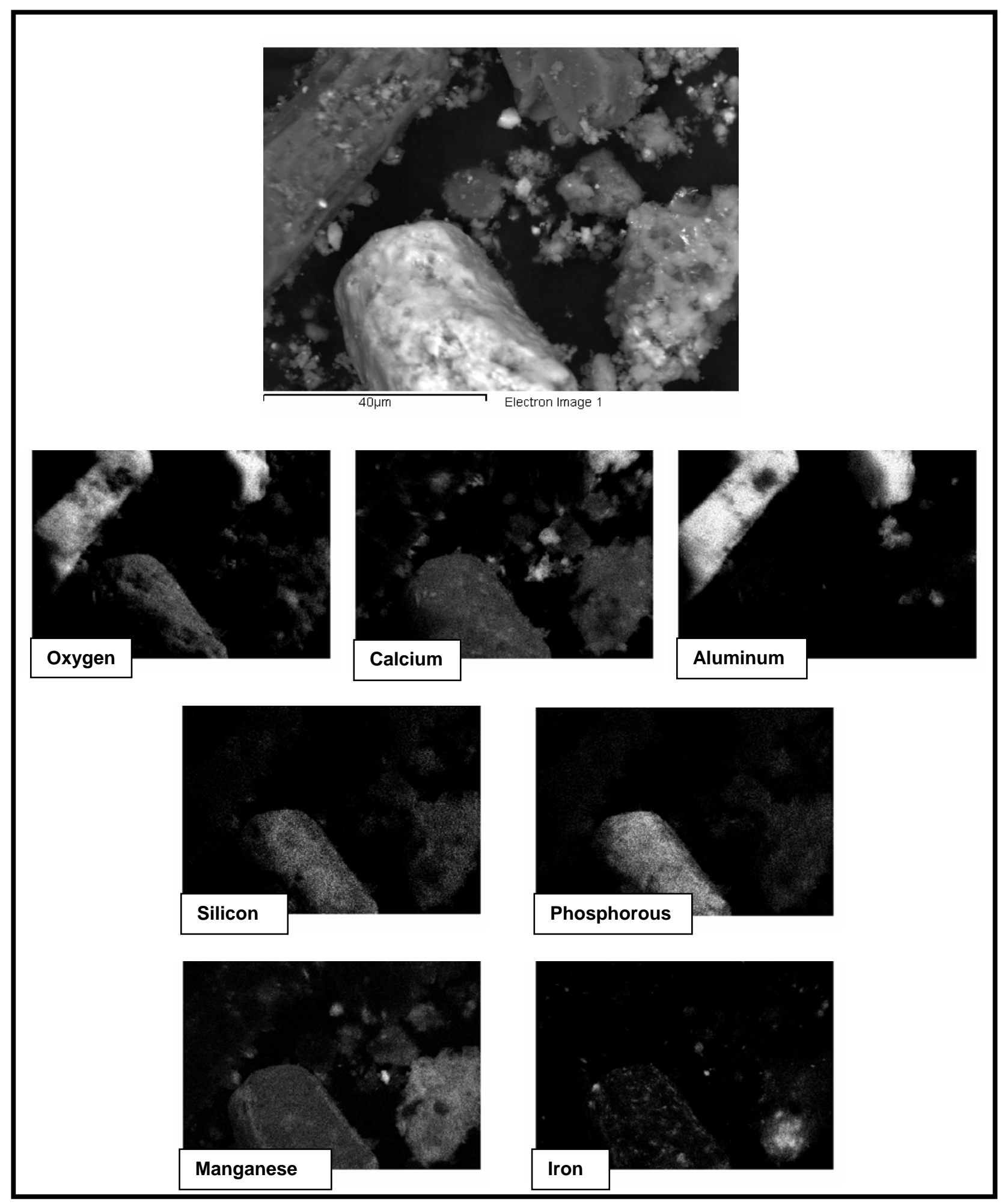

Figure 4.20. Backscatter-Electron SEM Micrograph and Element Distribution Maps for Particles in Stage 6 Sequential $\mathrm{CaCO}_{3}$-Leached C-106 Residual Waste 


\subsection{Contaminant Release Model}

The primary objective of this project is to develop source release models for contaminants of concern present in residual waste upon closure of Hanford single-shell tanks. As shown in Figure 5.1, developing these models consists of laboratory testing to produce contaminant release data and a conceptual source release model. After development, the release model can be incorporated into a fate and transport model as part of a long-term risk/performance assessment for the closed tank. A previously developed release model for residual sludge from tank C-106 assumed that the sludge was contacted with dilute water meant to simulate rainwater that has infiltrated through the vadose zone to contact the sludge (Deutsch et al. 2005a). This section describes a new conceptual release model developed for ${ }^{238} \mathrm{U},{ }^{99} \mathrm{Tc}, \mathrm{Cr}$, and ${ }^{129} \mathrm{I}$ for a scenario in which the residual sludge is covered with cementitious grout, which is under consideration as a component of the closure process.

Data collected and analyses conducted in Deutsch et al. (2005a) and in this study indicated that contaminant release from tank C-106 residual sludge will be geochemically complex. Contaminant release from the sludge is expected to involve mineral dissolution and precipitation, oxidation-reduction reactions, solution phase complexation, and surface adsorption. Some of these reactions can be modeled as equilibrium reactions whereas others will be rate controlled. Although significant insight was gained in this study regarding the contaminant release mechanisms that will be important for tank C-106 sludge, it was not possible to adequately characterize the phase associations of the contaminants of concern in sufficient detail to produce a mechanistically rigorous geochemical release model. This could change with additional work; however, in the meantime, a release model based on empirical solubilities has been developed. The approach used is inherently conservative and will over-estimate contaminant release. Further characterization work could allow the development of a more mechanistically rigorous geochemical release model, if warranted.

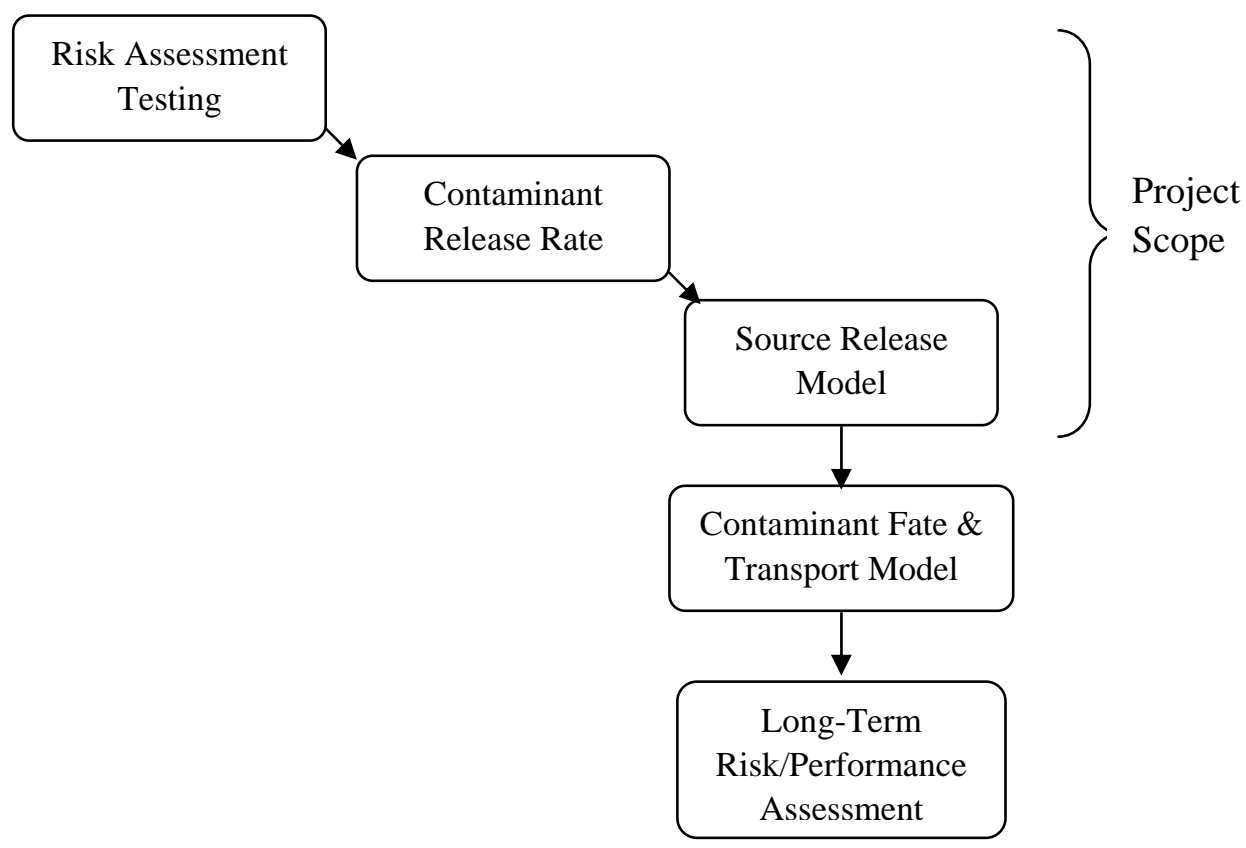

Figure 5.1. Source Release Model Development for Long-Term Risk/Performance Assessments 
The contaminant release models that have been developed for residual sludge in tank C-106 are based on empirical solubilities of the contaminants of concern. Empirical solubilities can be influenced by many geochemical conditions (e.g., $\mathrm{pH}$, Eh, ionic strength, presence/concentration of complexing species) that are potentially dynamic throughout the history of the evolving sludge environment. In addition, available data indicate that portions of the contaminants of concern are incorporated into slightly soluble phases. The dissolution of these relatively insoluble phases will likely control the long-term release of the contaminants of concern in the residual sludge. For these reasons, the release models described in this section are expected to be conservative only to tank conditions that are currently expected at closure and will need to be modified as additional information becomes available regarding different tank conditions.

\subsection{Modification of the Conceptual Model of Chemical Transformations of Tank C-106 Sludge Resulting from a Cementitious Tank Filler}

A conceptual model of the chemical transformations that have occurred in tank C-106 as a result of chemical treatments used in the sludge removal process has been described previously (Deutsch et al. 2005a). This model is shown schematically in Figure 4.2 of Deutsch et al. (2005b). The last box of that figure describing the water leaching process relevant to contaminant release has been modified here to account for the impact of cement. Figure 5.2 shows this modified portion of the figure.

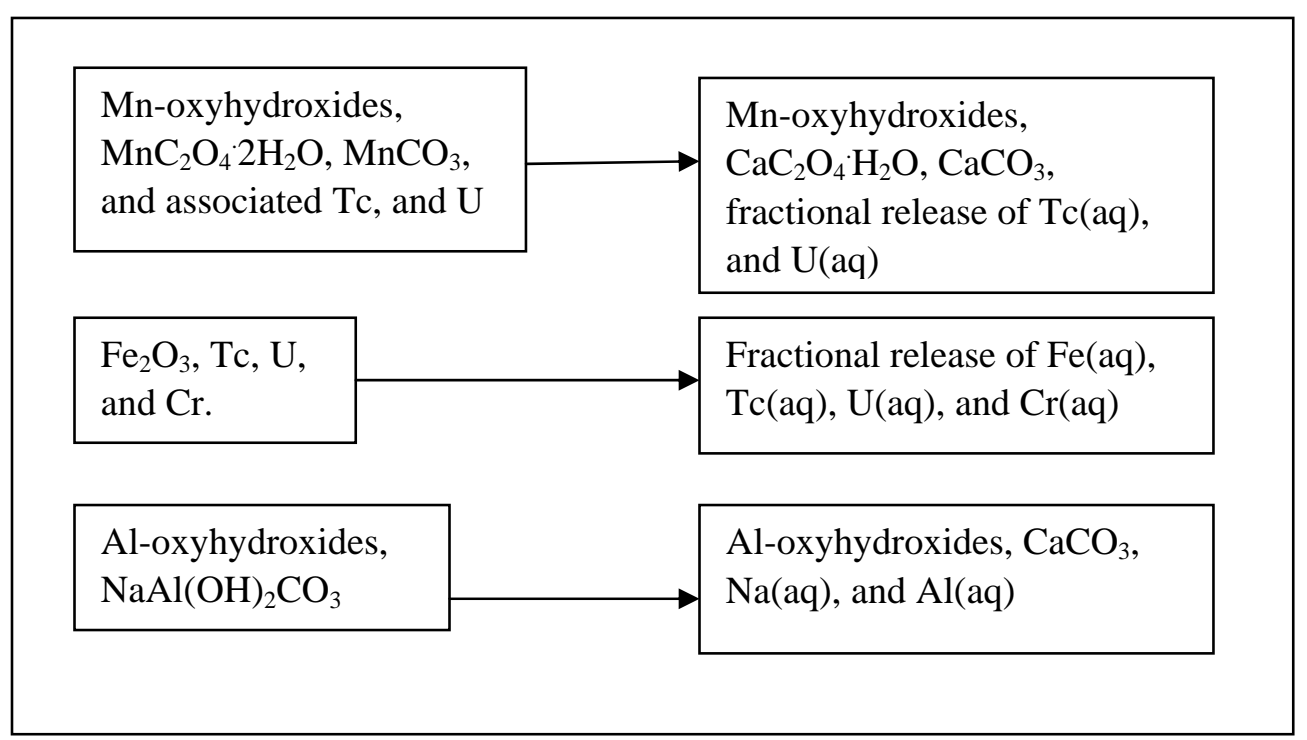

Figure 5.2. Chemical Transformations of Tank C-106 Residual Sludge Resulting from Contact with Cementitious Grout Leachate [0.01 $\left.\mathrm{M} \mathrm{Ca}(\mathrm{OH})_{2}\right]$

The modifications shown here indicate that instead of a dilute water contacting the sludge, as assumed in Deutsch et al. (2005a), a solution with a composition of $0.01 \mathrm{M} \mathrm{Ca}(\mathrm{OH})_{2}$ is assumed. The $0.01 \mathrm{M} \mathrm{Ca}(\mathrm{OH})_{2}$ is used here as a surrogate for infiltration water modified by contact with a cementitious grout placed in the tank as part of the closure process.

The XRD results discussed in Section 4.2 indicate that rhodochrosite, lindbergite, dawsonite, and hematite, originally present in the post-retrieval C-106 sludge are no longer present after contact with the 
$0.01 \mathrm{M} \mathrm{Ca}(\mathrm{OH})_{2}$ leachate. Calcite, which was not present in the unleached sample, was identified in the $0.01 \mathrm{M} \mathrm{Ca}(\mathrm{OH})_{2}$ leachate samples. Analysis of the $0.01 \mathrm{M} \mathrm{Ca}(\mathrm{OH})_{2}$ leachate solutions indicate that manganese, oxalate, and carbonate concentrations were below detection, suggesting that the majority of these components remain in the sludge during the leaching process. Significant concentrations of Al and Na were measured in the $0.01 \mathrm{M} \mathrm{Ca}(\mathrm{OH})_{2}$ leachates. This information suggests that leaching of $\mathrm{C}-106$ sludge with $0.01 \mathrm{M} \mathrm{Ca}(\mathrm{OH})_{2}$ results in a number of phase transformations:

- Rhodochrosite $\left(\mathrm{MnCO}_{3}\right)$ is converted to calcite $\left(\mathrm{CaCO}_{3}\right)$ and a poorly defined amorphous $\mathrm{Mn}$ oxyhydroxide phase.

- Lindbergite $\left(\mathrm{MnC}_{2} \mathrm{O}_{4} \cdot 2 \mathrm{H}_{2} \mathrm{O}\right)$ is converted to whewellite $\left(\mathrm{CaC}_{2} \mathrm{O}_{4} \cdot \mathrm{H}_{2} \mathrm{O}\right)$, and the poorly defined amorphous Mn oxyhydroxide phase.

- Dawsonite $\left(\mathrm{NaAl}(\mathrm{OH})_{2} \mathrm{CO}_{3}\right)$ is converted to calcite and dissolved $\mathrm{Na}$ and $\mathrm{Al}$.

Chemical equilibrium modeling indicates that under oxidizing conditions, all these reactions are thermodynamically favorable in $0.01 \mathrm{M} \mathrm{Ca}(\mathrm{OH})_{2}$. From a thermodynamic standpoint, the most stable $\mathrm{Mn}$ phase in equilibrium with air is pyrolusite $\left(\beta-\mathrm{MnO}_{2}\right)$. No Mn-oxyhydroxide phase was actually identified by XRD, so the phase is assumed to be amorphous. Although for the sake of simplicity this phase is referred to as an amorphous Mn-oxyhydroxide, SEM/EDS analysis suggests that this phase may actually be much more complicated: Ca-Mn-Al-Si-Fe $\pm \mathrm{Pb} \pm \mathrm{REE}(\mathrm{Ce}) \pm \mathrm{Cr}-\mathrm{P}-\mathrm{O} \pm \mathrm{C} \pm \mathrm{H}$.

The 1-month and six step $0.01 \mathrm{M} \mathrm{Ca}(\mathrm{OH})_{2}$ sequential leaches produced very similar XRD and SEM/EDS results. The 1-month and six step $0.01 \mathrm{M} \mathrm{CaCO}_{3}$ sequential leaches produced XRD and SEM/EDS results which were also very similar to the 1 -month and six step $0.01 \mathrm{M} \mathrm{Ca}(\mathrm{OH})_{2}$ sequential leaches with the exception that dawsonite was identified in the 1-month $0.01 \mathrm{M} \mathrm{CaCO}_{3}$ leached sample. Based on these results, the transformations discussed above and outlined in Figure 5.2 will be used as the working hypothesis for the reaction of water contacting both fresh cement grout and aged cement grout and then contacting the residual sludge in tank C-106 after closure.

\subsection{Release Models for Technetium, Uranium, Iodine, and Chromium in a Tank Filled with Cementitious Grout}

Because of the highly complex chemical nature of tank C-106 residual sludge, clear and quantitative phase associations of the contaminants of concern with the phases known to exist in the residual sludge are difficult to specify. Although the various characterization methods employed in this study have revealed a number of important observations and have provided valuable data for constructing a scientifically defensible release model, many questions remain. Because a thorough understanding of all the important phase associations for the contaminants of concern cannot be developed at this time, an empirically based release model has been developed. Although less satisfying from a mechanistic point of view, this provides a release model that can be used now and is conservative in nature. Later work may provide a better understanding of the phase associations with the contaminants of concern and the release mechanisms from these phases; in this case, a less conservative, but more scientifically defensible release model could be developed.

Maximum release rates for ${ }^{99} \mathrm{Tc},{ }^{238} \mathrm{U}$, and $\mathrm{Cr}$, from sludge extracts using $\mathrm{Ca}(\mathrm{OH})_{2}$ (fresh cement stimulant) and $\mathrm{CaCO}_{3}$ (aged cement stimulant) were determined from the 1-month water leachates. This 
was done because the measured concentrations in these leachates were generally higher than those measured in the short term sequential leach extracts. Because it is necessary to rely on empirical release data for the release model, this more conservative approach is preferred. In addition, a longer leaching period is more representative of actual water/waste contact times expected in the future.

Table 5.1 is a summary of the contaminant release model data for tank C-106 for the fresh cement $\left(0.01 \mathrm{M} \mathrm{Ca}(\mathrm{OH})_{2}\right)$ scenario. For ${ }^{129} \mathrm{I}$ and $\mathrm{Cr}$, measured concentrations in the leachates were below the detection limits; therefore, the detection limit values were used for the release concentration. Total sludge concentrations are provided in column 2 of Table 5.1. These values were determined, as indicated in Deutsch et al. (2005a), from either the fusion or EPA Method 3050B acid digestions of the sludge, whichever had the highest concentration.

Table 5.1. Summary of Contaminant Release Model Data for Tank C-106, Fresh Cement (0.01 M $\left.\mathrm{Ca}(\mathrm{OH})_{2}\right)$ Scenario

\begin{tabular}{||c|c|c|c||}
\hline \hline Contaminant & Sludge Concentration & Release Concentration & Release Control \\
\hline \hline${ }^{99} \mathrm{Tc}$ & $\begin{array}{c}1.2 \mu \mathrm{\mu g}{ }^{99} \mathrm{Tc} / \mathrm{g} \text {-sludge } \\
\left(20,000 \mu \mathrm{pCi}{ }^{99} \mathrm{Tc} / \mathrm{g} \text {-sludge }\right)\end{array}$ & $\begin{array}{c}1.2 \mu \mathrm{g} / \mathrm{L} \\
(20,000 \mathrm{pCi} / \mathrm{L})\end{array}$ & solubility \\
\hline${ }^{238} \mathrm{U}$ & $310 \mu \mathrm{g}{ }^{238} \mathrm{U} / \mathrm{g}$-sludge & $36 \mu \mathrm{g} / \mathrm{L}$ & solubility \\
\hline${ }^{129} \mathrm{I}$ & $0.62 \mu \mathrm{g}{ }^{129} \mathrm{I} / \mathrm{g}$-sludge & $0.17 \mu \mathrm{g} / \mathrm{L}$ & solubility \\
\hline $\mathrm{Cr}$ & $897 \mu \mathrm{pg} \mathrm{Cr} / \mathrm{g}$-sludge & $<470 \mu \mathrm{g} / \mathrm{L}$ & solubility \\
\hline
\end{tabular}

Table 5.2 is a summary of the contaminant release model data for tank C-106 for the aged cement ( $\mathrm{CaCO}_{3}$-equilibrium) scenario. ${ }^{129} \mathrm{I}$ and $\mathrm{Cr}$ were not measured above their respective detection limits; therefore, the detection limit values were used for the release concentrations.

Table 5.2. Summary of Contaminant Release Model Data for Tank C-106, Aged Cement $\left(\mathrm{CaCO}_{3^{-}}\right.$ equilibrium) Scenario

\begin{tabular}{|c|c|c|c|}
\hline Contaminant & Sludge Concentration & Release Concentration & Release Control \\
\hline${ }^{99} \mathrm{Tc}$ & $\begin{array}{c}1.2 \mu \mathrm{g}{ }^{99} \mathrm{Tc} / g-s l u d g e \\
\left(20,000 \mathrm{pCi}^{99} \mathrm{Tc} / \text { g-sludge }\right)\end{array}$ & $\begin{array}{c}0.39 \mu \mathrm{g} / \mathrm{L} \\
(6,600 \mathrm{pCi} / \mathrm{L})\end{array}$ & solubility \\
\hline${ }^{238} \mathrm{U}$ & $310 \mu g{ }^{238} \mathrm{U} / g$-sludge & $49 \mu \mathrm{g} / \mathrm{L}$ & solubility \\
\hline${ }^{129} \mathrm{I}$ & $\begin{array}{c}0.62 \mu \mathrm{g}^{129} \mathrm{I} / \mathrm{g} \text {-sludge } \\
\text { (110 pCi }{ }^{129} \mathrm{I} / \text { g-sludge) }\end{array}$ & $\begin{array}{l}0.35 \mu \mathrm{g} / \mathrm{L} \\
(61 \mathrm{pCi} / \mathrm{L})\end{array}$ & solubility \\
\hline $\mathrm{Cr}$ & 897 g Cr/g-sludge & $<283 \mu \mathrm{g} / \mathrm{L}$ & solubility \\
\hline
\end{tabular}

The data for the previous water leach release scenario from Deutsch et al. (2005a) are provided below in Table 5.3. Comparison of these data with the data in Table 5.1 and Table 5.2, indicate that for tank C-106 sludge, the presence of cement above the sludge does not have a large impact on contaminant mobility. The presence of cement has the biggest impact on ${ }^{99}$ Tc. For the water leach scenario, the release concentration for ${ }^{99} \mathrm{Tc}$ is $0.21 \mu \mathrm{g} / \mathrm{L}$, whereas the fresh cement concentration is $1.2 \mu \mathrm{g} / \mathrm{L}$. For the aged cement scenario the ${ }^{99}$ Tc release concentration is $0.39 \mu \mathrm{g} / \mathrm{L}$; similar to that of the water release scenario. For ${ }^{238} \mathrm{U}$, both the fresh cement and aged cement scenarios have release concentrations which 
are similar to that of the water release scenario. Comparisons for ${ }^{129} \mathrm{I}$ and $\mathrm{Cr}$ are not useful because the detection limits of these constituents in the cement leachates were higher than the water release scenario concentrations.

Table 5.3. Summary of Contaminant Release Model Data for C-106, Fresh Water Scenario

\begin{tabular}{|c|c|c|c|}
\hline Contaminant & Sludge Concentration & Release Concentration & Release Control \\
\hline${ }^{99} \mathrm{Tc}$ & $\begin{array}{c}1.2 \mu \mathrm{g}^{99} \mathrm{Tc} / \mathrm{g} \text {-sludge } \\
\text { (20,000 } \mathrm{PCi}{ }^{99} \mathrm{Tc} / \mathrm{g}-\text {-sludge) }\end{array}$ & $\begin{array}{c}0.21 \mu \mathrm{g} / \mathrm{L} \\
(3,600 \mathrm{pCi} / \mathrm{L})\end{array}$ & solubility \\
\hline${ }^{238} \mathrm{U}$ & $310 \mu g{ }^{238} \mathrm{U} / g$-sludge & $46 \mu \mathrm{g} / \mathrm{L}$ & solubility \\
\hline${ }^{129} \mathrm{I}$ & $\begin{array}{c}0.62 \mu \mathrm{g}{ }^{129} \mathrm{I} / \text { g-sludge } \\
\left(110 \mathrm{pCi}^{129} \mathrm{I} / \text { g-sludge }\right)\end{array}$ & $\begin{array}{l}0.059 \mu \mathrm{g} / \mathrm{L} \\
(10 \mathrm{pCi} / \mathrm{L})\end{array}$ & solubility \\
\hline $\mathrm{Cr}$ & $897 \mu g$ Cr/g-sludge & $19 \mu \mathrm{g} / \mathrm{L}$ & solubility \\
\hline
\end{tabular}




\subsection{Conclusions}

This report provides the results of laboratory tests on residual sludge from Hanford tank C-106 that has been contacted with solutions leaching from cementitious grout that may be used to fill the Hanford tanks. The impact of these leaching solutions on the long-term release of contaminants from the residual sludge has been evaluated. The major conclusions from this work are discussed in this section.

Contact of the residual tank sludge with the $0.01 \mathrm{M} \mathrm{Ca}(\mathrm{OH})_{2}$ solution that represents leachate from the grout produced the following mineral transformations:

- Rhodochrosite $\left(\mathrm{MnCO}_{3}\right)$ is converted to calcite $\left(\mathrm{CaCO}_{3}\right)$ and a poorly defined amorphous $\mathrm{Mn}$ oxyhydroxide phase.

- Lindbergite $\left(\mathrm{MnC}_{2} \mathrm{O}_{4} \cdot 2 \mathrm{H}_{2} \mathrm{O}\right)$ is converted to whewellite $\left(\mathrm{CaC}_{2} \mathrm{O}_{4} \cdot \mathrm{H}_{2} \mathrm{O}\right)$, and a poorly defined amorphous Mn oxyhydroxide phase.

- Dawsonite $\left(\mathrm{NaAl}(\mathrm{OH})_{2} \mathrm{CO}_{3}\right)$ is converted to calcite and dissolved $\mathrm{Na}$ and $\mathrm{Al}$.

The primary reasons for these transformations are the high Ca concentration of the leachate and its high $\mathrm{pH}(\sim 12)$.

The effect of the cementitious leachate on the mobility of components in the sludge can be summarized as follows:

- ${ }^{99} \mathrm{Tc}$ is more leachable in the $\mathrm{Ca}(\mathrm{OH})_{2}$ leachant than in DDI water by a factor of 6 ; however, the amount of the total ${ }^{99}$ Tc in the sludge that is leachable increases to only $\sim 10 \%$.

- ${ }^{238} \mathrm{U}$ is less leachable in the $\mathrm{Ca}(\mathrm{OH})_{2}$ leachant than in DDI water for the sequential contact leaching tests. Approximately $4 \%$ was water leachable through the six contact stages while $<1 \%$ was leached during six stages with the $\mathrm{Ca}(\mathrm{OH})_{2}$ leachant.

- ${ }^{129}$ I was not detected in any of the leaching tests showing its generally recalcitrant nature in this sludge material.

- ${ }^{90} \mathrm{Sr}$ is more leachable in the $\mathrm{Ca}(\mathrm{OH})_{2}$ leachant than in DDI water. This is likely a result of cation exchange of $\mathrm{Ca}$ for $\mathrm{Sr}$ on the solid phase ion exchange sites.

- ${ }^{137} \mathrm{Cs}$ is much more leachable in the sequential contact $\mathrm{Ca}(\mathrm{OH})_{2}$ leachant tests than in DDI water tests. The increase in leachability for some stages of these tests is a factor of 100 . This may also be a result of cation exchange of Ca for Cs.

- $\mathrm{Cr}$ and Fe were also not detected in any of the leaching tests designed to simulate the impact of a cementitious cover on the sludge. 
- $\mathrm{Al}$ is more leachable by a factor of about 10 for the cementitious leachants compared to DDI water leaches. This is due to the amphoteric behaviour of $\mathrm{Al}$ solution species and the high $\mathrm{pH}$ of these cementitious leach tests.

- Mn is less leachable in the cementitious leachants probably because the amorphous Mn oxyhydroxide phase listed above as a conversion product of rhodochrosite and lindbergite is less soluble in the high $\mathrm{pH}(\sim 12)$ cementitious environment that its predecessors in the lower $\mathrm{pH}(\sim 7)$ of the DDI water leachant.

- Oxalate is less leachable in the cementitious leachants because the high concentration of $\mathrm{Ca}(0.01 \mathrm{M})$ in these leachants depresses the solubility of whewellite $\left(\mathrm{CaC}_{2} \mathrm{O}_{4} \cdot \mathrm{H}_{2} \mathrm{O}\right)$.

A summary of the release models for the primary contaminants of concern is provided in Tables 5.1 through 5.3. 


\subsection{References}

10 CFR 830.120. “Quality Assurance.” Code of Federal Regulations, U.S. Department of Energy.

ASME. 1989. Quality Assurance Program Requirements for Nuclear Facilities/with Addenda. NQA-11989. American Society of Mechnical Engineers, New York.

ASTM. 1998. D2216-98 Standard Test Method for Laboratory Determination of Water (Moisture) Content of Soil and Rock by Mass. American Society for Testing and Materials, West Conshohocken, Pennsylvania.

ASTM. 1999. D3987-85 Standard Test Method for Shake Extraction of Solid Waste with Water. American Society for Testing and Materials, West Conshohocken, Pennsylvania.

Bechtold DB, GA Cooke, DL Herting, JC Person, RS Viswanath, and RW Warrant. 2003. Laboratory Testing of Oxalic Acid Dissolution of Tank 241-C-106 Sludge. RPP-17158, Rev. 0, Fluor Hanford, Inc. Richland, Washington.

Clesceri LS, AE Greenberg, and AD Eaton. 1998. Standard Methods for the Examination of Water and Wastewater, 20th Edition. American Public Health Association, American Water Works Association, and Water Environment Federation, Washington, D.C.

Conner JM. 1996. Tank Characterization Report for Single-Shell Tank 241-C-204.

WHC-SD-WM-ER-479 Rev. 0, Westinghouse Hanford Company, Richland, Washington.

Deutsch WJ, KM Krupka, MJ Lindberg, KJ Cantrell, CF Brown, and HT Schaef. 2005a. Hanford Tank C-106: Residual Waste Contaminant Release Model and Supporting Data. PNNL-15187, Pacific Northwest National Laboratory, Richland, Washington.

Deutsch WJ, KM Krupka, KJ Cantrell, CF Brown, MJ Lindberg, HT Schaef, SM Heald, and BW Arey. 2005b. Advances in Geochemical Testing of Key Contaminants in Residual Hanford Tank Waste.

PNNL-15372, Pacific Northwest National Laboratory, Richland, Washington.

DOE. 1998. Hanford Analytical Services Quality Assurance Requirements Documents. HASQARD, DOE/RL-96-68, Volumes 1, 2, 3, and 4, U.S. Department of Energy, Richland, Washington.

DOE Order 414.1A. Management Assessment and Independent Assessment Guide. U.S. Department of Energy, Washington, D.C. Available online at http://www.directives.doe.gov/pdfs/doe/doetext/neword/414/g4141-1a.html

EPA. 1994a. "Method 6020. Inductively Coupled Plasma-Mass Spectrometry.” In Test Methods for Evaluating Solid Wastes: Physical/Chemical Methods, EPA SW-846, Third Ed., Vol. I, Section A, Chapter 3 (Inorganic Analytes), pp. 6020-1 to 6020-18, U.S. Environmental Protection Agency, Office of Solid Waste and Emergency Response, Washington, D.C. Available at: http://www.epa.gov/epaoswer/hazwaste/test/pdfs/6020.pdf 
EPA. 1994b. "Method 9056. Determination of Inorganic Anions by Ion Chromatography." In Test Methods for Evaluating Solid Wastes: Physical/Chemical Methods, EPA SW-846, Third Ed., Vol. I, Section C, Chapter 5 (Miscellaneous Test Methods), pp. 9056-1 to 9056-16, U.S. Environmental Protection Agency, Office of Solid Waste and Emergency Response, Washington, D.C. Available at: http://www.epa.gov/epaoswer/hazwaste/test/pdfs/9056.pdf

EPA. 1995. "Method 9040B. pH Electrometric Measurement.” In Test Methods for Evaluating Solid Wastes: Physical/Chemical Methods, EPA SW-846, Third Ed., Vol. I, Section C, Chapter 8 (Methods for Determining Characteristics), pp. 9040B-1 to 9040B-5, U.S. Environmental Protection Agency, Office of Solid Waste and Emergency Response, Washington, D.C. Available at: http://www.epa.gov/epaoswer/hazwaste/test/pdfs/9040b.pdf

EPA. 1996. "Method 6010B. Inductively Coupled Plasma-Atomic Emission Spectrometry.” In Test Methods for Evaluating Solid Wastes: Physical/Chemical Methods, EPA SW-846, Third Ed., Vol. I, Section A, Chapter 3 (Inorganic Analytes), pp. 6010B-1 to 6010B-25, U.S. Environmental Protection Agency, Office of Solid Waste and Emergency Response, Washington, D.C. Available at: http://www.epa.gov/epaoswer/hazwaste/test/pdfs/6010b.pdf

Krupka KM, WJ Deutsch, MJ Lindberg, KJ Cantrell, NJ Hess, HT Schaef, and BW Arey. 2004. Hanford Tanks 241-AY-102 and 241-BX-101: Sludge Composition and Contaminant Release Data. PNNL-14614, Pacific Northwest National Laboratory, Richland, Washington.

Strachan DM, HT Schaef, MJ Schweiger, KL Simmons, LJ Woodcock, and MK Krouse. 2003. “A Versatile and Inexpensive XRD Specimen Holder for Highly Radioactive or Hazardous Specimens.” Powder Diffraction 18(1):23-28. 


\section{Appendix A}

$\mathrm{X}$-Ray Diffraction Patterns for $\mathrm{Ca}(\mathrm{OH})_{2}$ - and $\mathrm{Ca}(\mathrm{OH})_{2} / \mathrm{CaCO}_{3}$-Leached Tank C-106 Residual Waste 


\section{Appendix A}

\section{$\mathrm{X}$-Ray Diffraction Patterns for $\mathrm{Ca}(\mathrm{OH})_{2}$ - and $\mathrm{Ca}(\mathrm{OH})_{2} / \mathrm{CaCO}_{3}$-Leached Tank C-106 Residual Waste}

This appendix presents the as-measured (before background subtraction) $\mathrm{x}$-ray powder diffraction (XRD) patterns for 1-month and stage 6 sequential $\mathrm{Ca}(\mathrm{OH})_{2}$ - and $\mathrm{Ca}(\mathrm{OH})_{2} / \mathrm{CaCO}_{3}$-leached residual waste from tank 241-C-106 (C-106). As noted in Section 3.3, trace quantities of reference-material corundum $\left(\alpha-\mathrm{Al}_{2} \mathrm{O}_{3}\right.$, alumina) [National Institute of Standards and Technology Standard Reference Material (NIST SRM) 676] powder were added to each XRD mount to provide an internal $2 \theta$ standard for each XRD pattern. The instrumentation and procedures used for measuring, subtracting background, and interpreting the XRD patterns for these materials are described in Section 3.3 of the main report.

The vertical axis in each of the following patterns represents the intensity in counts per second (cps) of the XRD peaks. The horizontal axis is in terms of degrees $2 \theta$ based on $\mathrm{Cu}_{\mathrm{K \alpha} \alpha}$ radiation $(\lambda=1.5406 \AA)$, and is related to $d$ spacing according to the Bragg law (Cullity 1956). ${ }^{\text {(a) }}$ The as-measured XRD pattern for the unleached C-106 residual waste and the relevant schematic database (PDF) patterns are shown along with the as-measured XRD patterns for the 1-month and stage 6 sequential $\mathrm{Ca}(\mathrm{OH})_{2}$-leached samples in Figure A.1, and with the patterns for the 1-month and stage 6 sequential $\mathrm{Ca}(\mathrm{OH})_{2} / \mathrm{CaCO}_{3}$-leached samples in Figure A.2. For comparison to the background signal in the as-measured XRD patterns included in this appendix, Figure A.3 shows the XRD pattern for collodion film measured in the absence of any sludge material and reported by Krupka et al. (2004). ${ }^{\text {(b) }}$ Figures A.4 through A.8 show, respectively, the individual as-measured XRD patterns for unleached, 1-month $\mathrm{Ca}(\mathrm{OH})_{2}$-leached, stage 6 sequential $\mathrm{Ca}(\mathrm{OH})_{2}$-leached, 1 -month $\mathrm{Ca}(\mathrm{OH})_{2} / \mathrm{CaCO}_{3}$-leached, and stage 6 sequential $\mathrm{Ca}(\mathrm{OH})_{2} / \mathrm{CaCO}_{3}$-leached residual waste from tank $\mathrm{C}-106$.

(a) Cullity BD. 1967. Elements of X-Ray Diffraction. Addison-Wesley Publishing Company, Inc., Reading, Massachusetts.

(b) Krupka KM, WJ Deutsch, MJ Lindberg, KJ Cantrell, NJ Hess, HT Schaef, and BW Arey. 2004. Hanford Tanks 241-AY-102 and 241-BX-101: Sludge Composition and Contaminant Release Data. PNNL-14614, Pacific Northwest National Laboratory, Richland, Washington. 


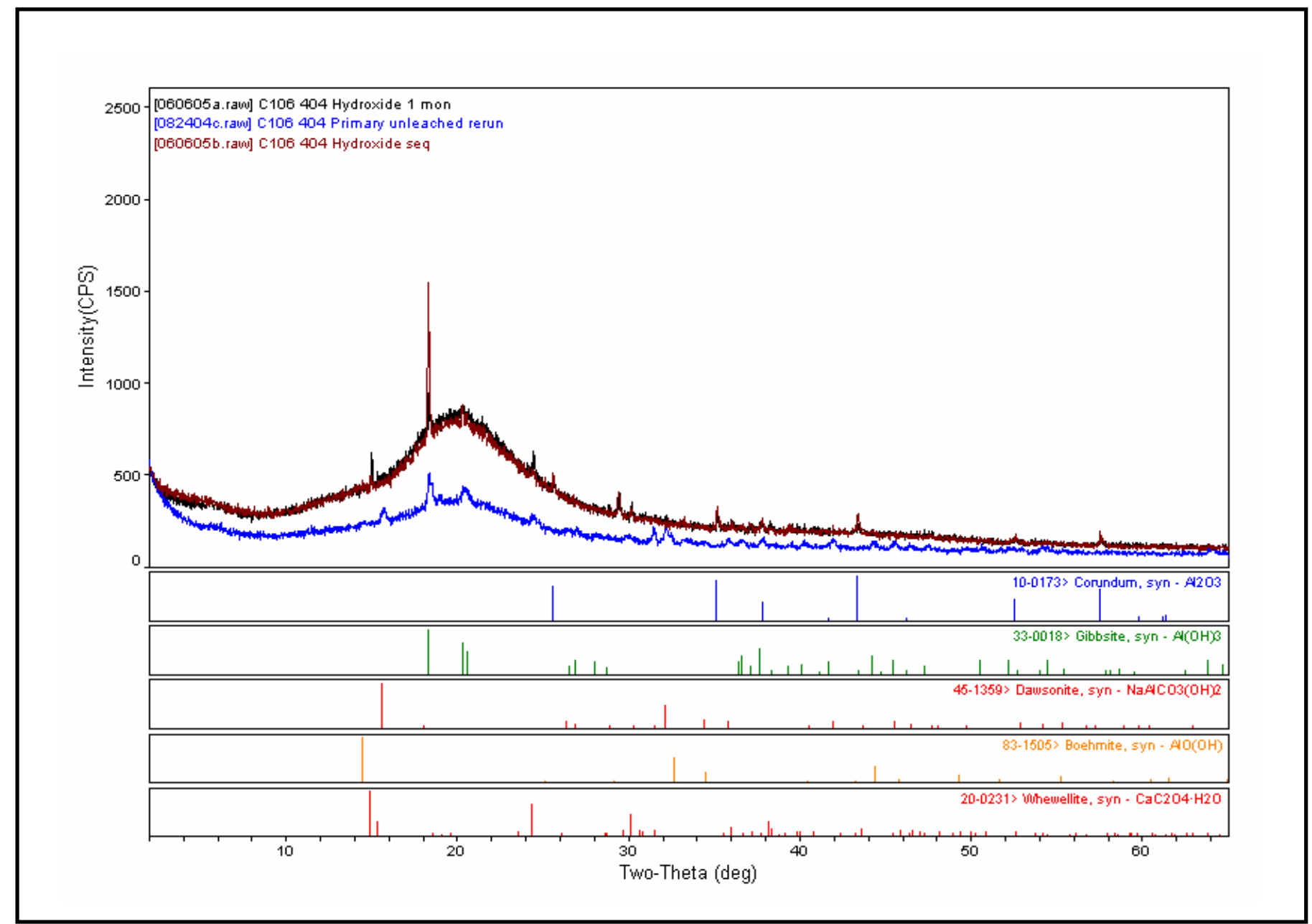

Figure A.1. As-Measured XRD Pattern (without background subtraction) for Unleached C-106 Residual Waste (blue trace) and Relevant Schematic Database (PDF) Patterns Compared to As-Measured XRD Patterns for the 1-Month (black trace) and Stage 6 Sequential $\mathrm{Ca}(\mathrm{OH})_{2}$-Leached (maroon trace) C-106 Residual Waste 


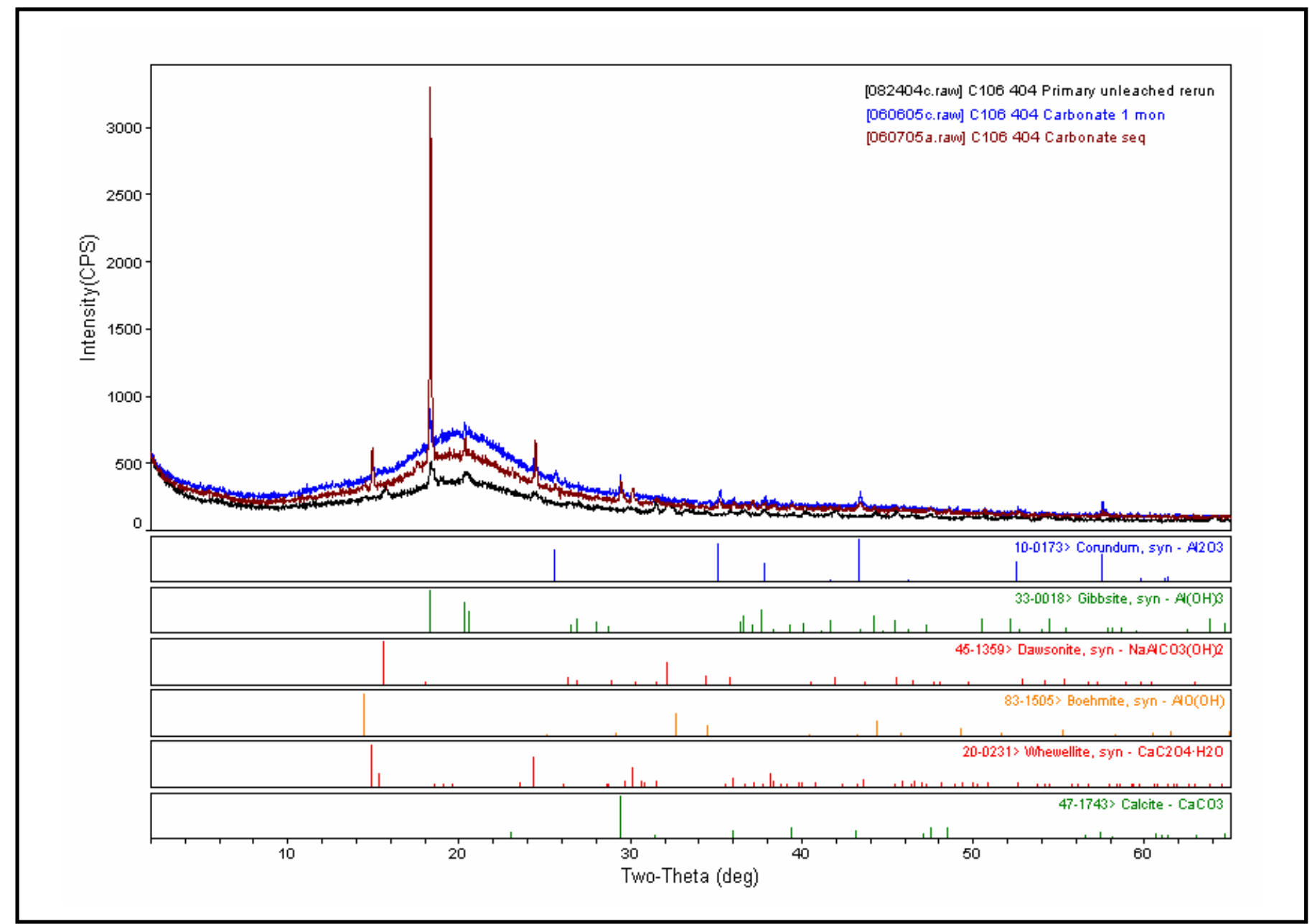

Figure A.2. As-Measured XRD Pattern (without background subtraction) for Unleached C-106 Residual Waste (black trace) and Relevant Schematic Database (PDF) Patterns Compared to As-Measured XRD Patterns for the 1-Month (blue trace) and Stage 6 Sequential $\mathrm{Ca}(\mathrm{OH})_{2} / \mathrm{CaCO}_{3}$-Leached (maroon trace) C-106 Residual Waste 


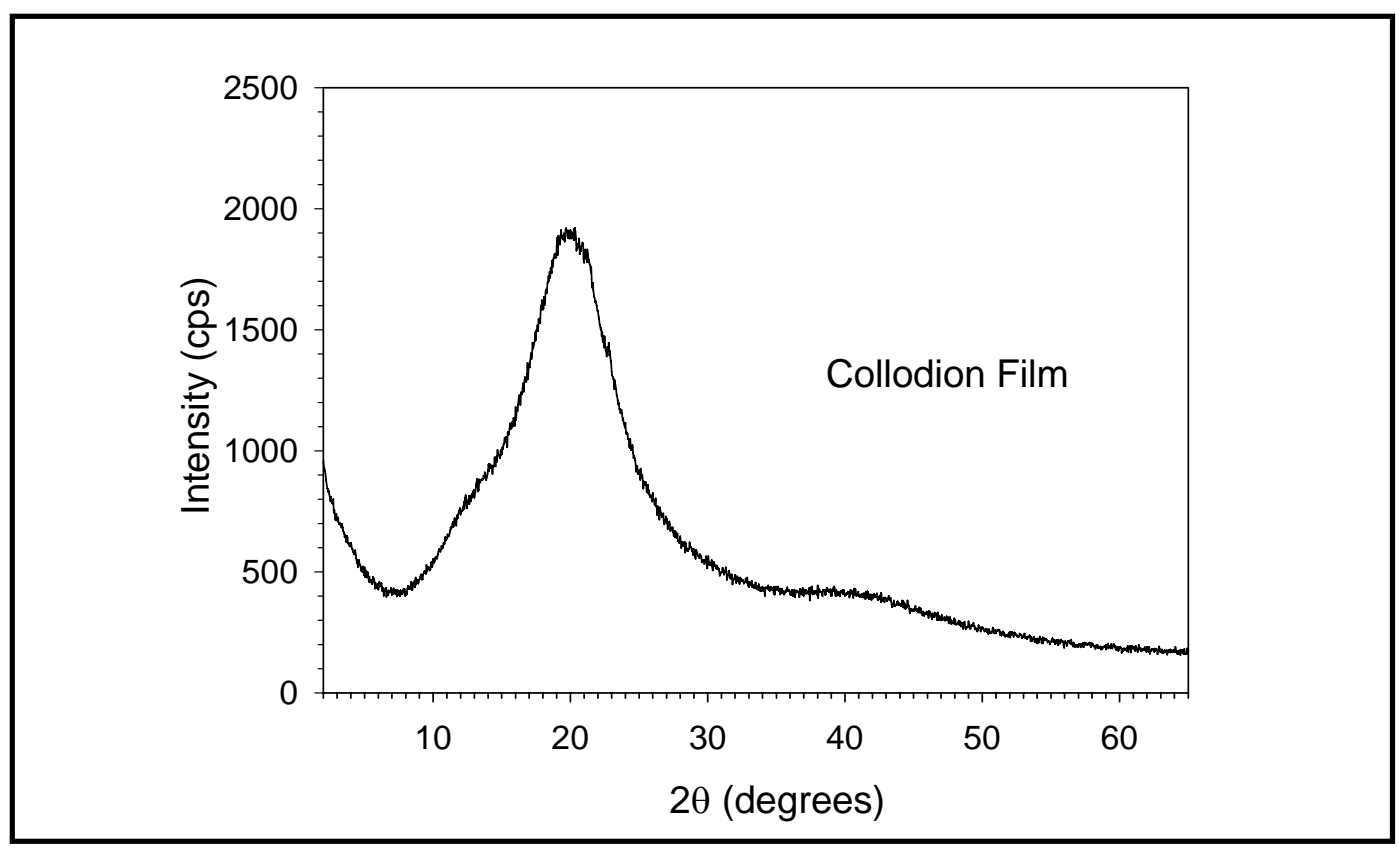

Figure A.3. XRD Pattern for Collodion-Solution Film (from Krupka et al. 2004)

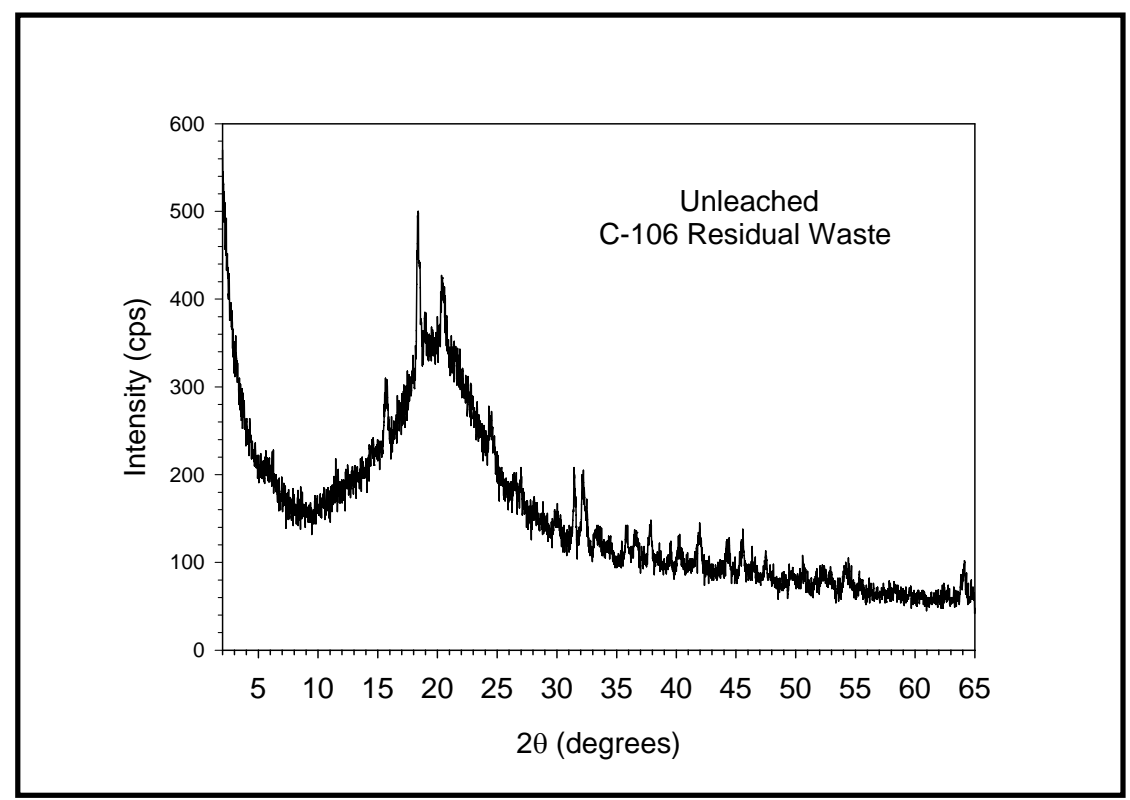

Figure A.4. As-Measured XRD Pattern (without background subtraction) for Unleached C-106 Residual Waste 


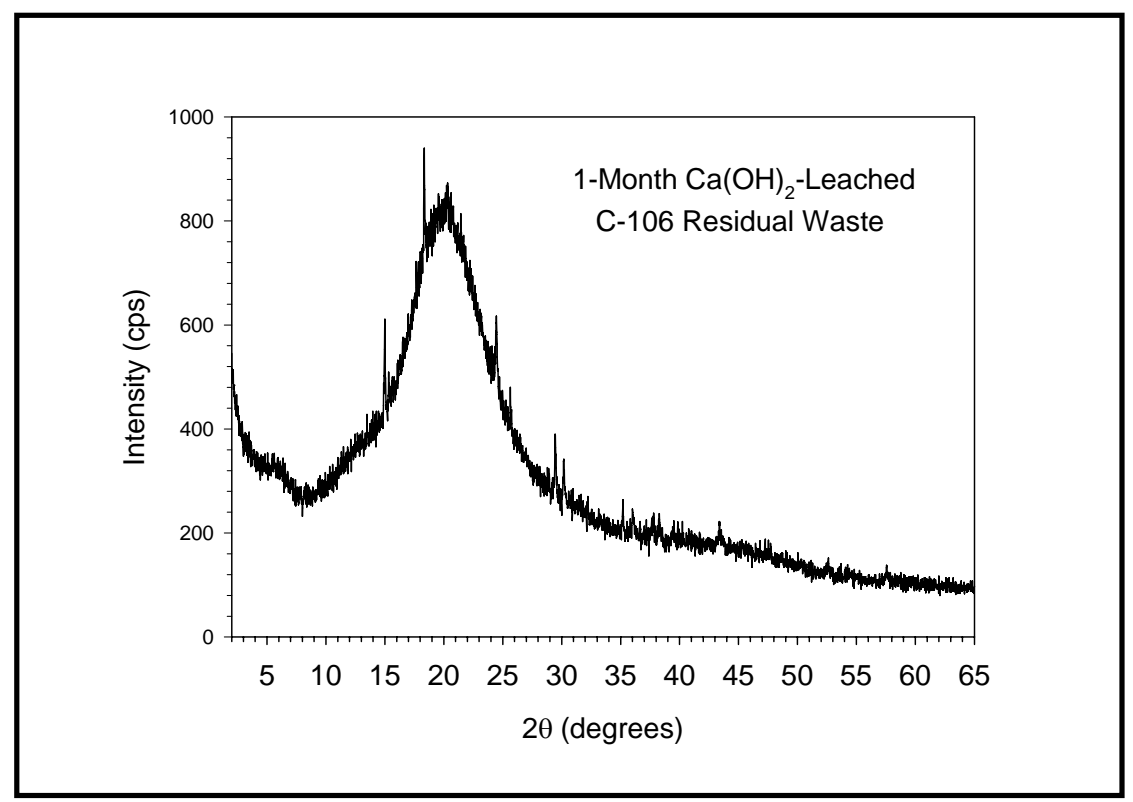

Figure A.5. As-Measured XRD Pattern (without background subtraction) for 1-Month $\mathrm{Ca}(\mathrm{OH})_{2}$-Leached Residual Waste from Tank C-106

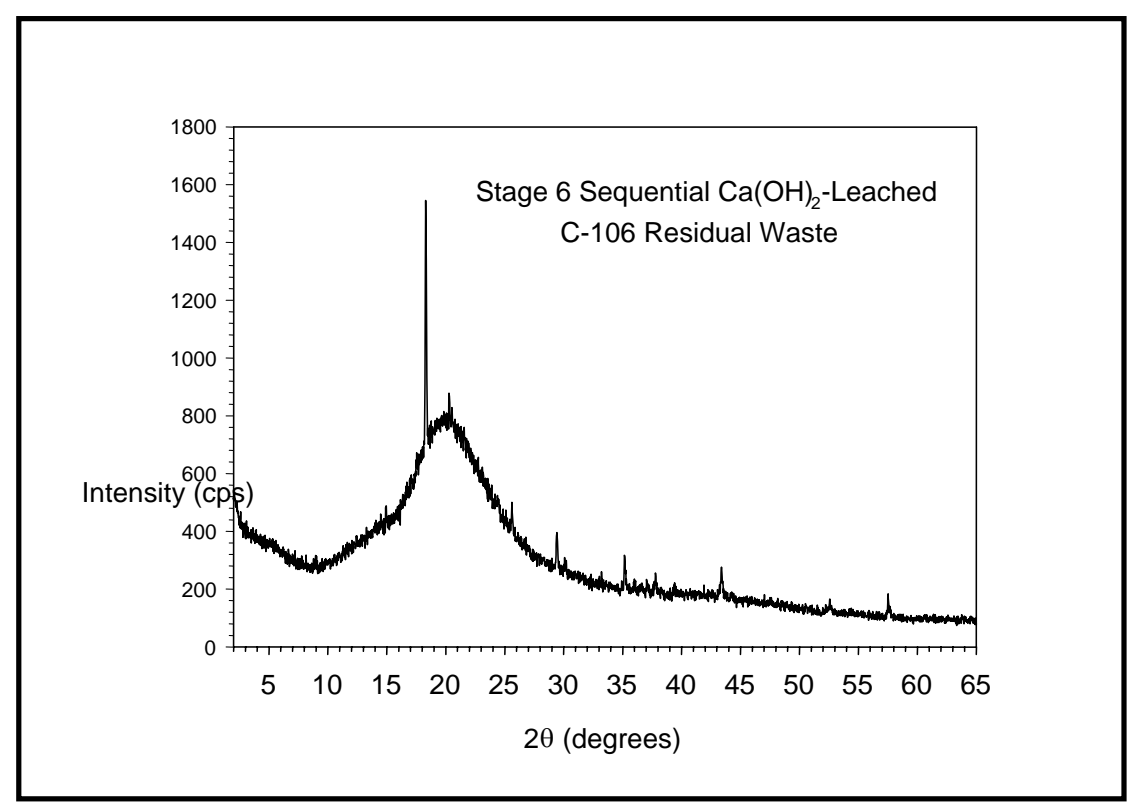

Figure A.6. As-Measured XRD Pattern (without background subtraction) for Stage 6 Sequential $\mathrm{Ca}(\mathrm{OH})_{2}$-Leached Residual Waste from Tank C-106 


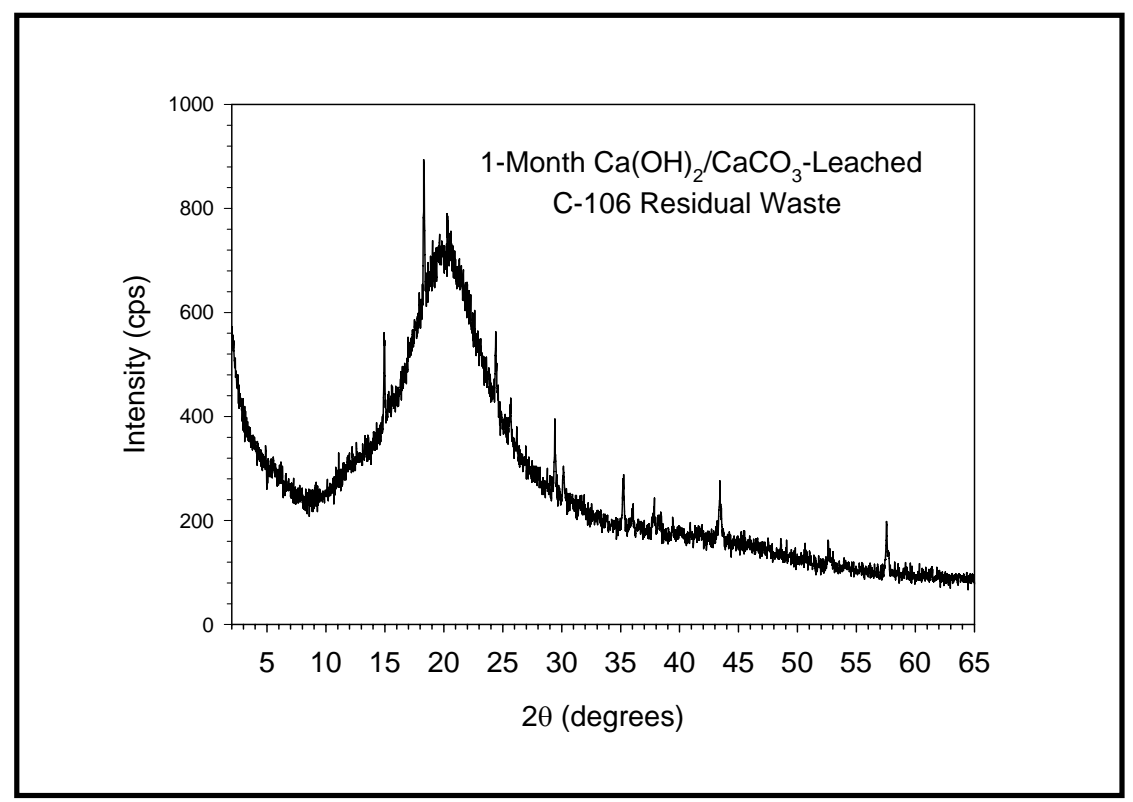

Figure A.7. As-Measured XRD Pattern (without background subtraction) for 1-Month $\mathrm{Ca}(\mathrm{OH})_{2} / \mathrm{CaCO}_{3}$-Leached Residual Waste from Tank C-106

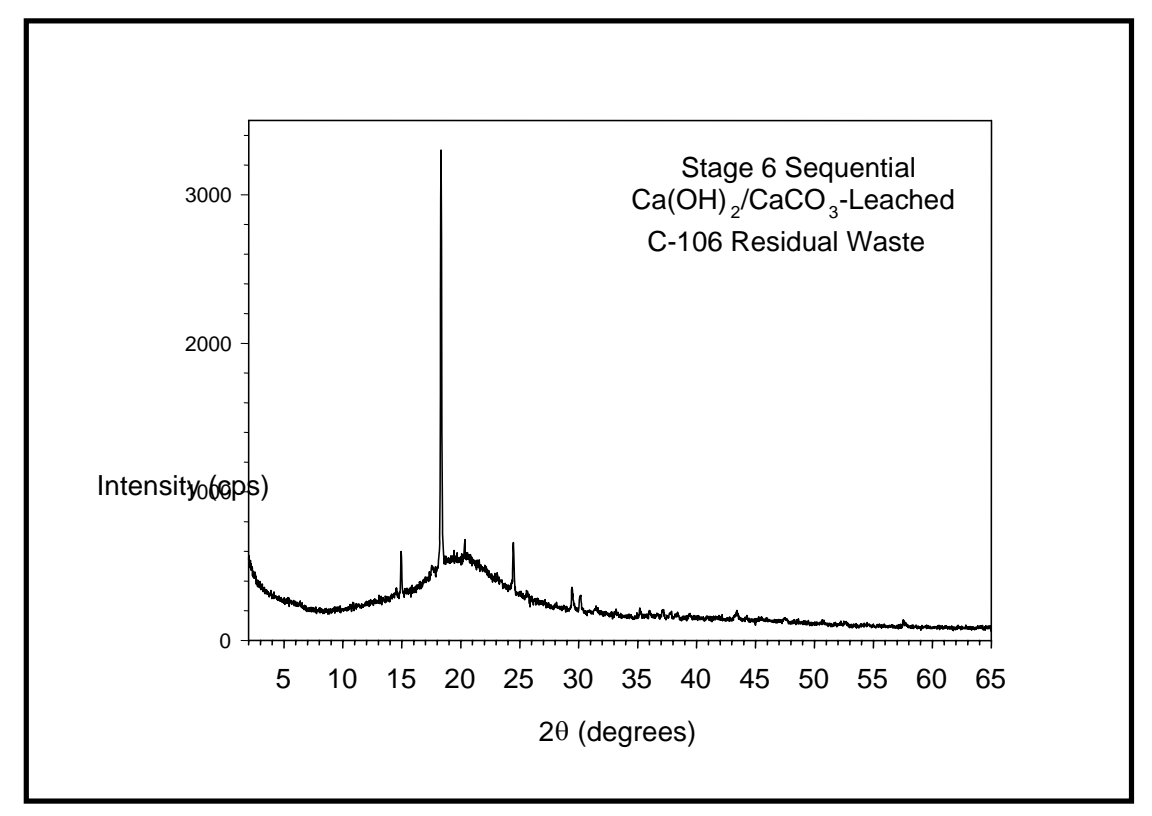

Figure A.8. As-Measured XRD Pattern (without background subtraction) for Stage 6 Sequential $\mathrm{Ca}(\mathrm{OH})_{2} / \mathrm{CaCO}_{3}$-Leached Residual Waste from Tank C-106 


\section{Appendix B}

\section{SEM Micrographs and EDS Results for 1-Month $\mathrm{Ca}(\mathrm{OH})_{2}$-Leached Tank C-106 Residual Waste}




\section{Appendix B}

\section{SEM Micrographs and EDS Results for 1-Month $\mathrm{Ca}(\mathrm{OH})_{2}$ Leached Tank C-106 Residual Waste}

This appendix includes the scanning electron microscope (SEM) micrographs and energy-dispersive $\mathrm{x}$-ray spectrometry (EDS) spectra for samples of 1-month $\mathrm{Ca}(\mathrm{OH})_{2}$-leached residual waste from tank $\mathrm{C}$-106. The operating conditions for the SEM and procedures used for mounting the SEM samples are described in Section 3.4 of the main report.

The identification number for the digital micrograph image file, descriptor for the type of sample, and a size scale bar are given, respectively, at the bottom left, center, and right of each SEM micrograph in this appendix. Micrographs labeled by "BSE" to the immediate right of the digital image file number indicate that the micrograph was collected with backscattered electrons. Sample areas or particles identified by a letter, arrow, and/or outlined by white or black dotted-line squares in a micrograph designate sample material that was imaged at higher magnification and is typically shown in figure(s) that immediately follow in the series for that sample. The SEM micrographs for this leached material are shown in Figures B.1 through B.19. The EDS spectra for this material are given in Figures B.20 through B.30. 


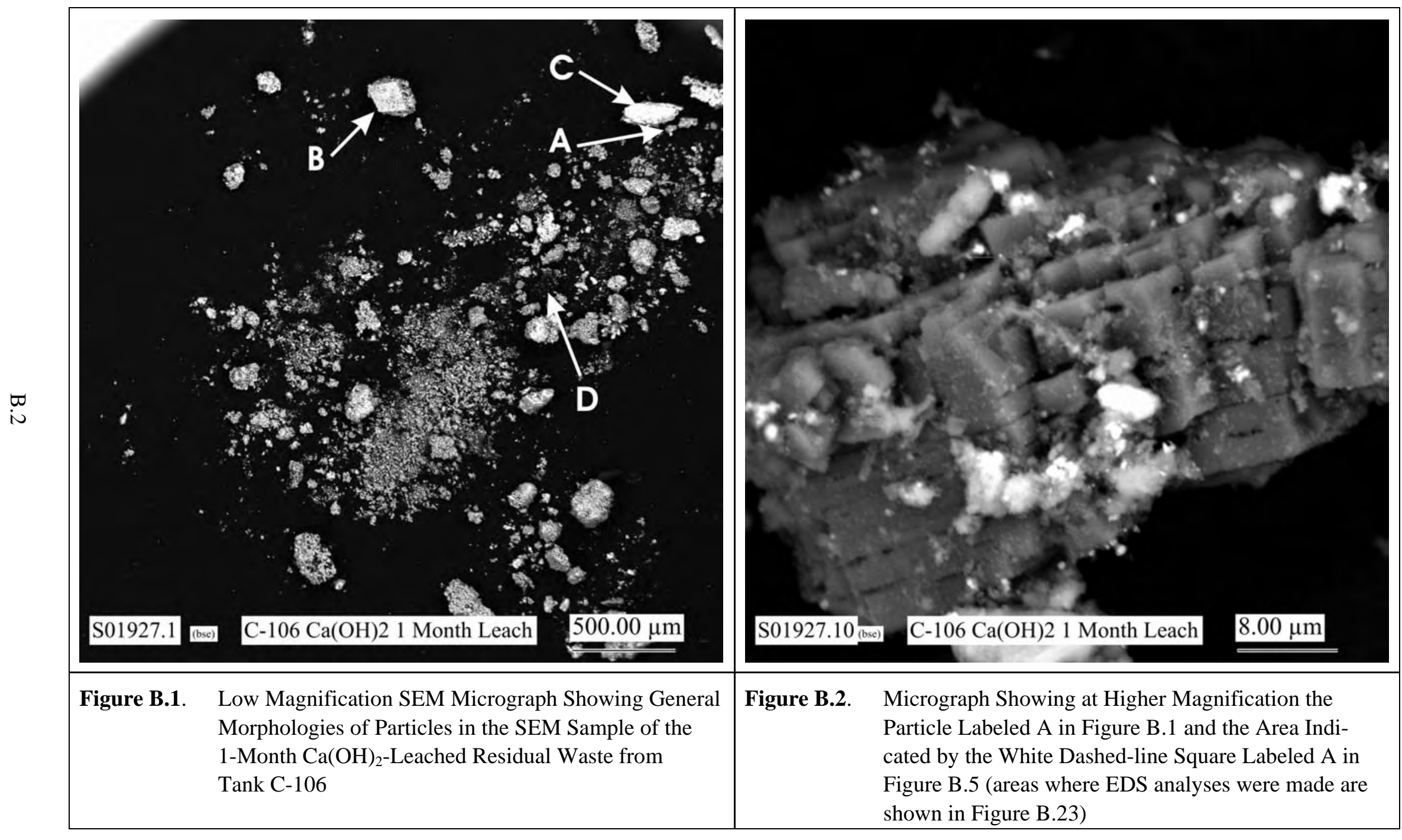




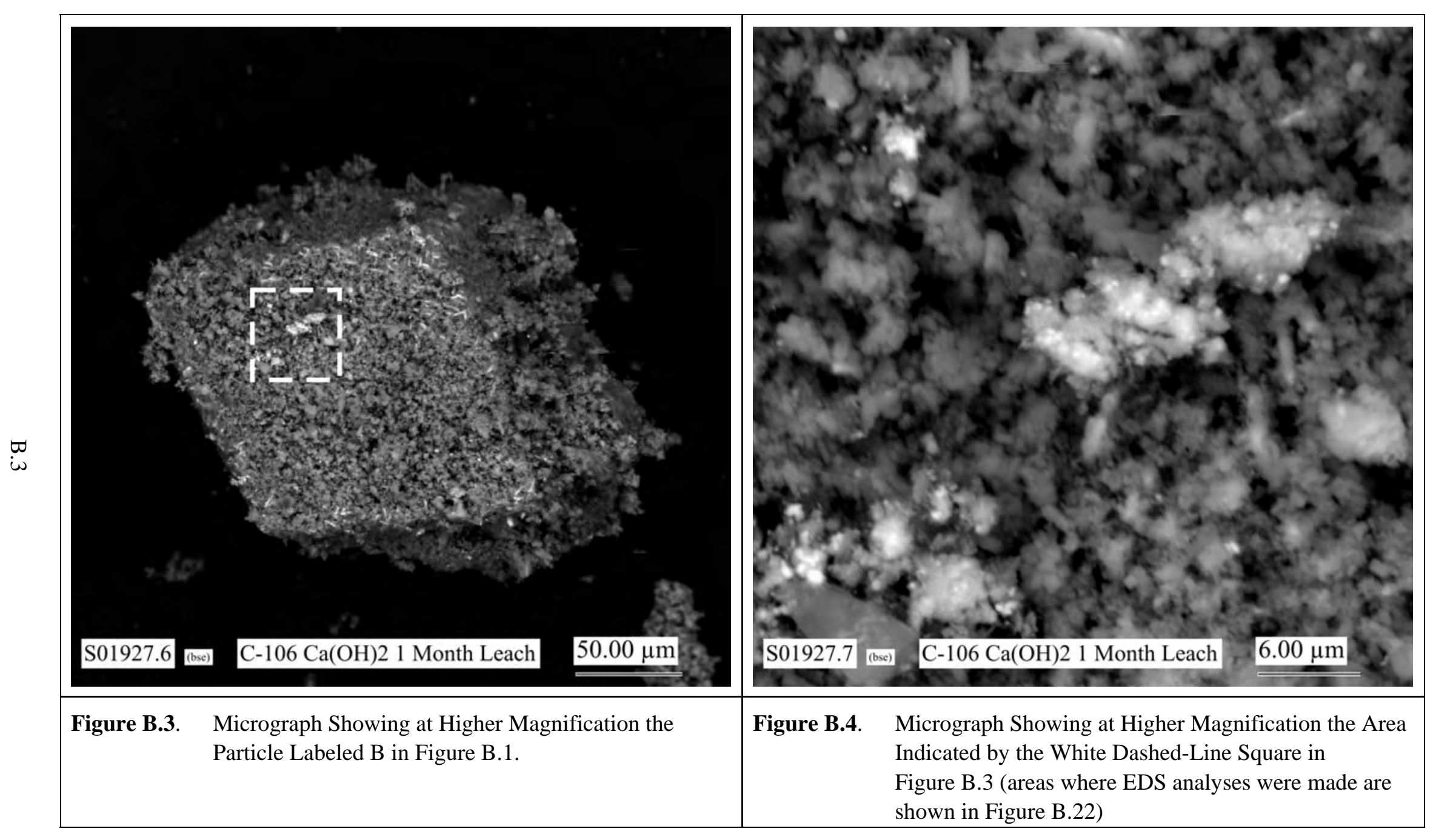




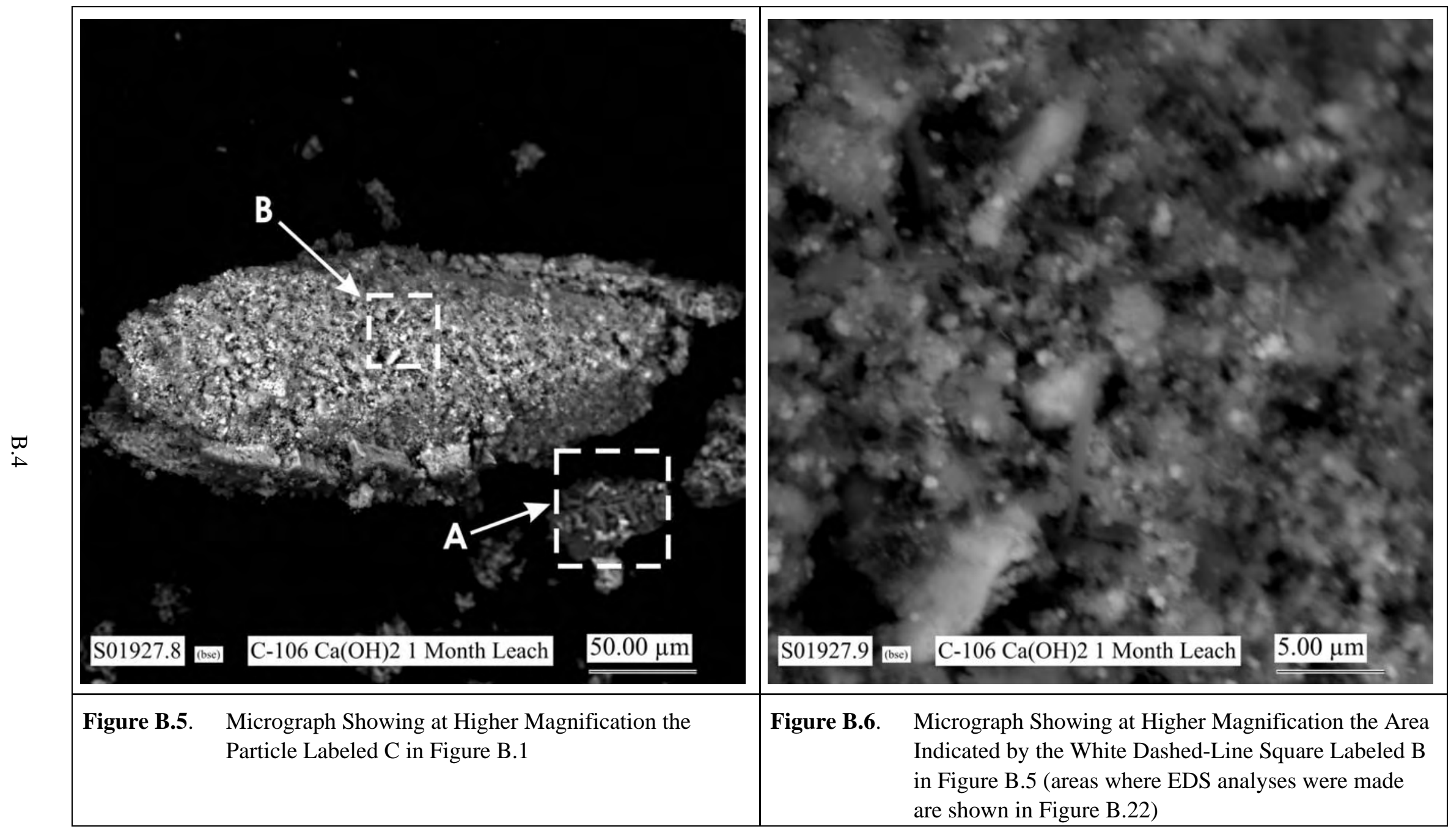




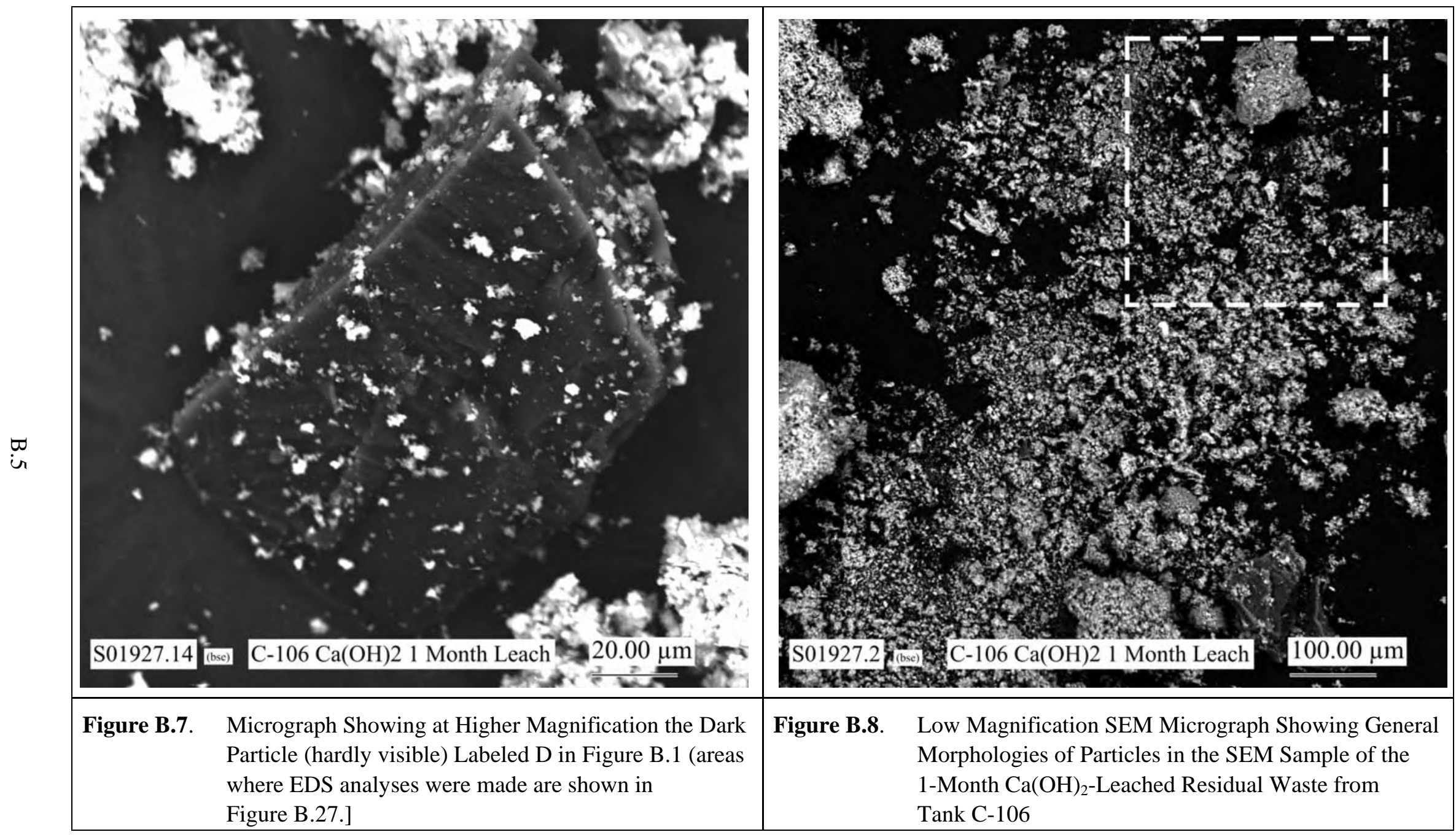




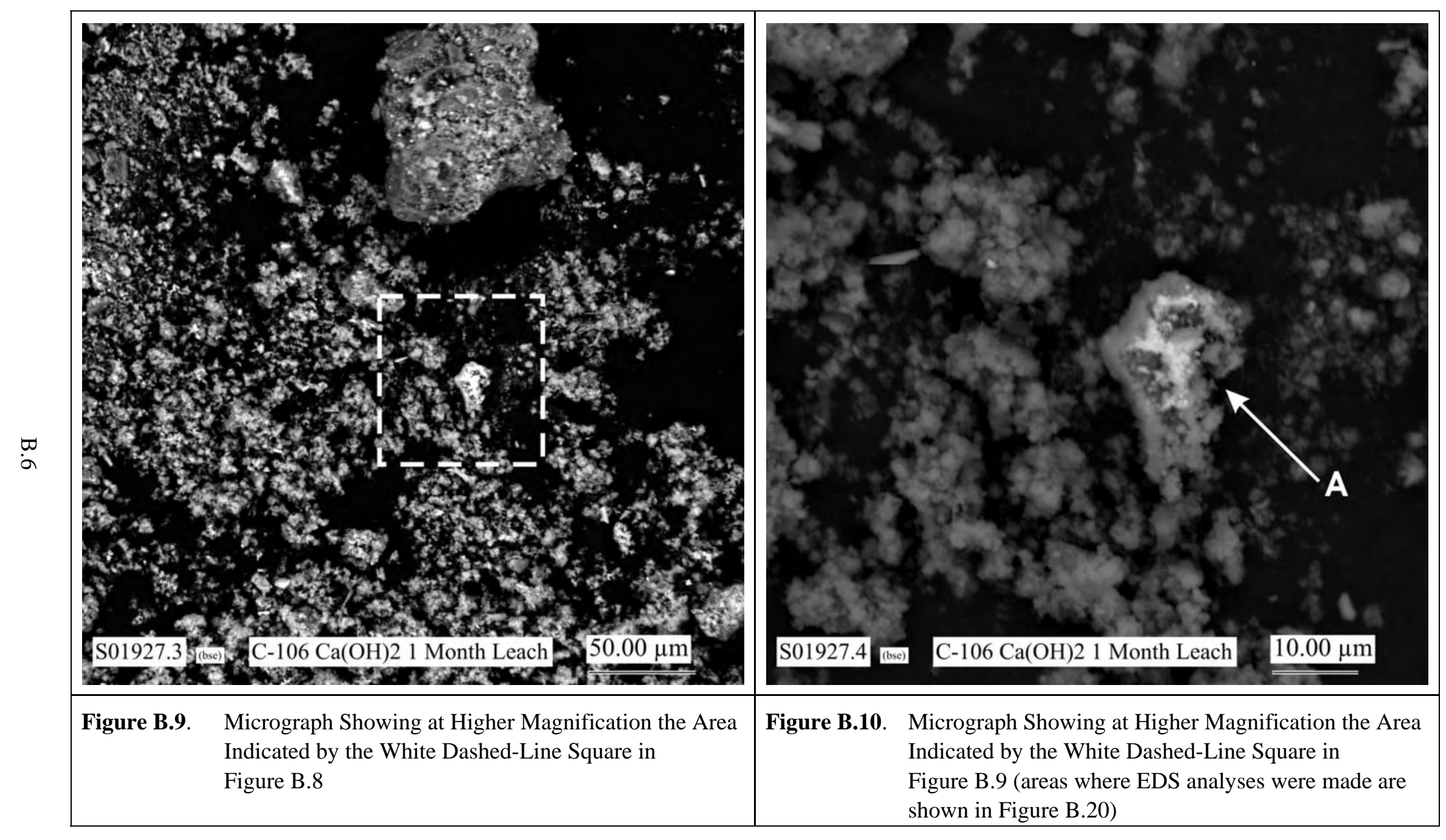




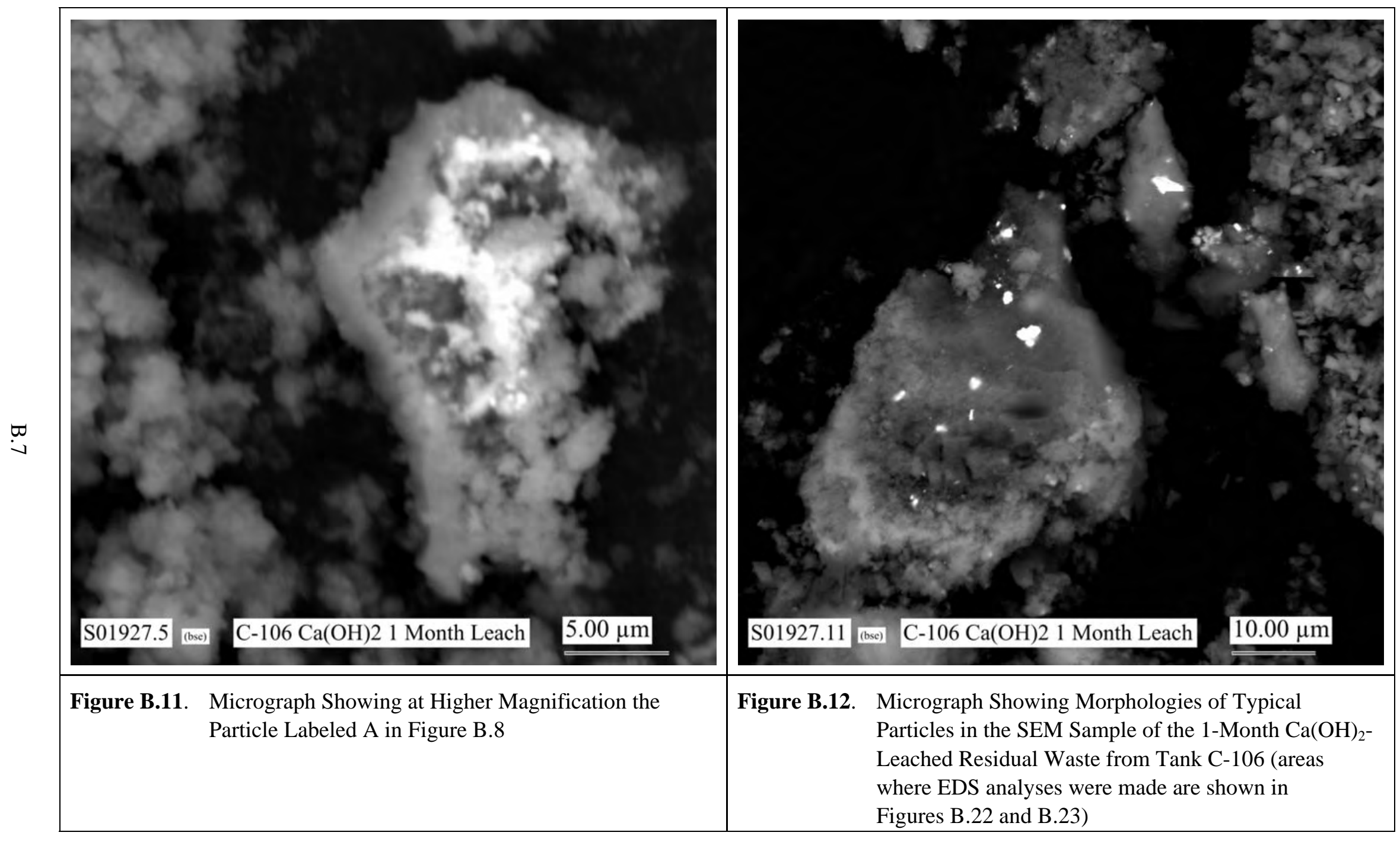




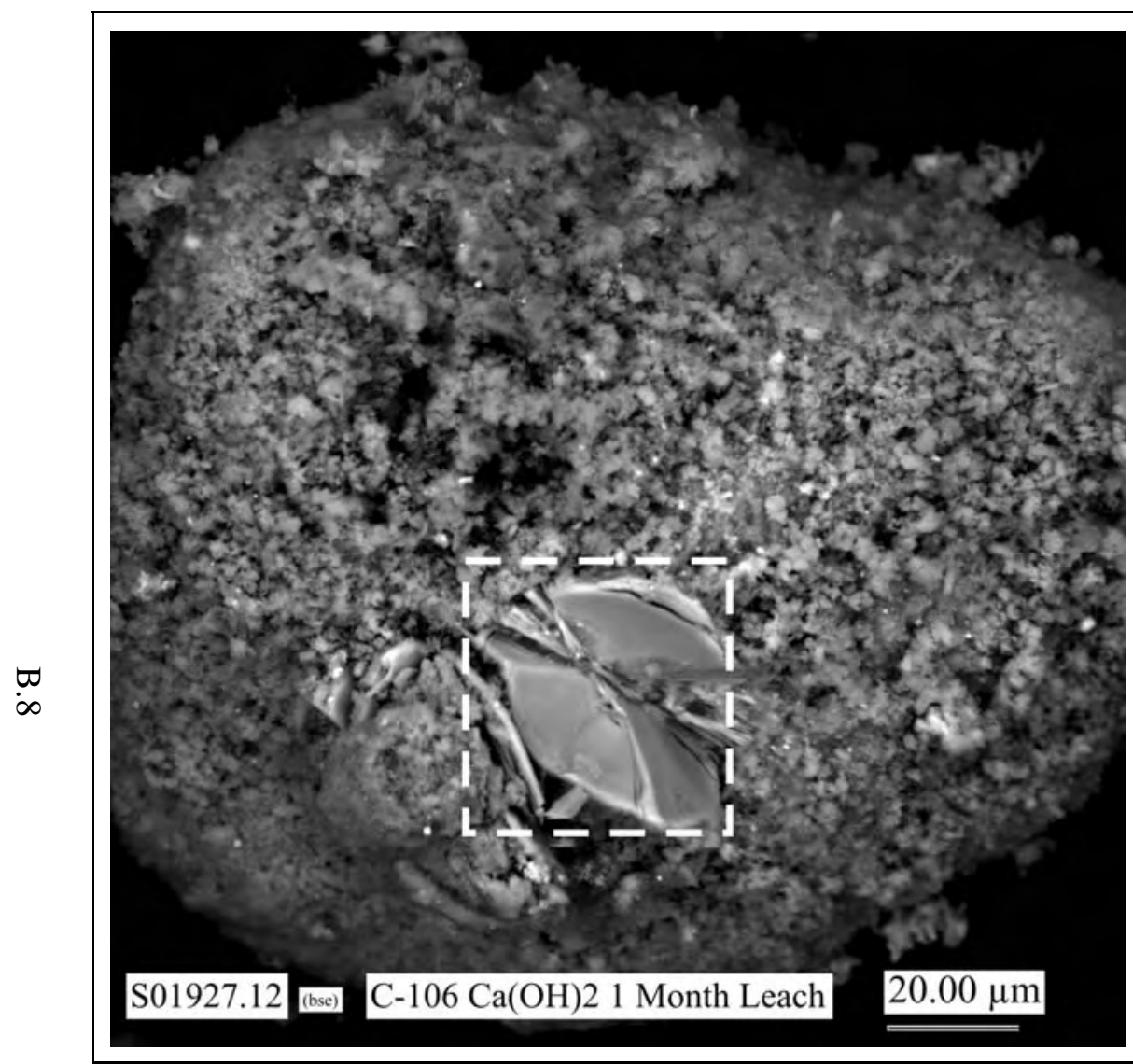

Figure B.13. Micrograph Showing Morphologies of Particles in the SEM of 1-Month $\mathrm{Ca}(\mathrm{OH})_{2}$-Leached Residual Waste from Tank C-106

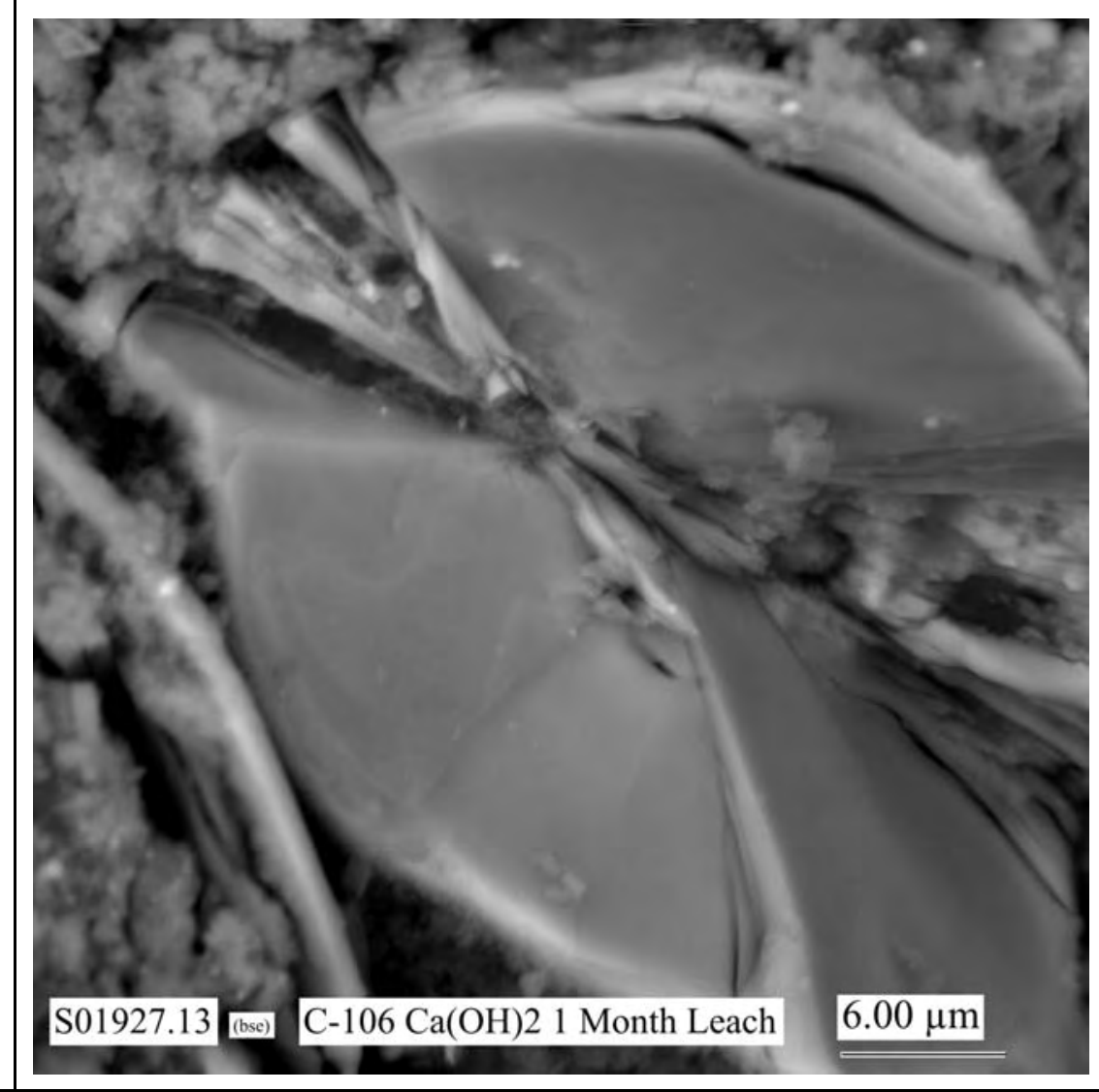

Figure B.14. Micrograph Showing at Higher Magnification the Area Indicated by the White Dashed-Line Square in

Figure B.11 (areas where EDS analyses were made are shown in Figure B.24) 


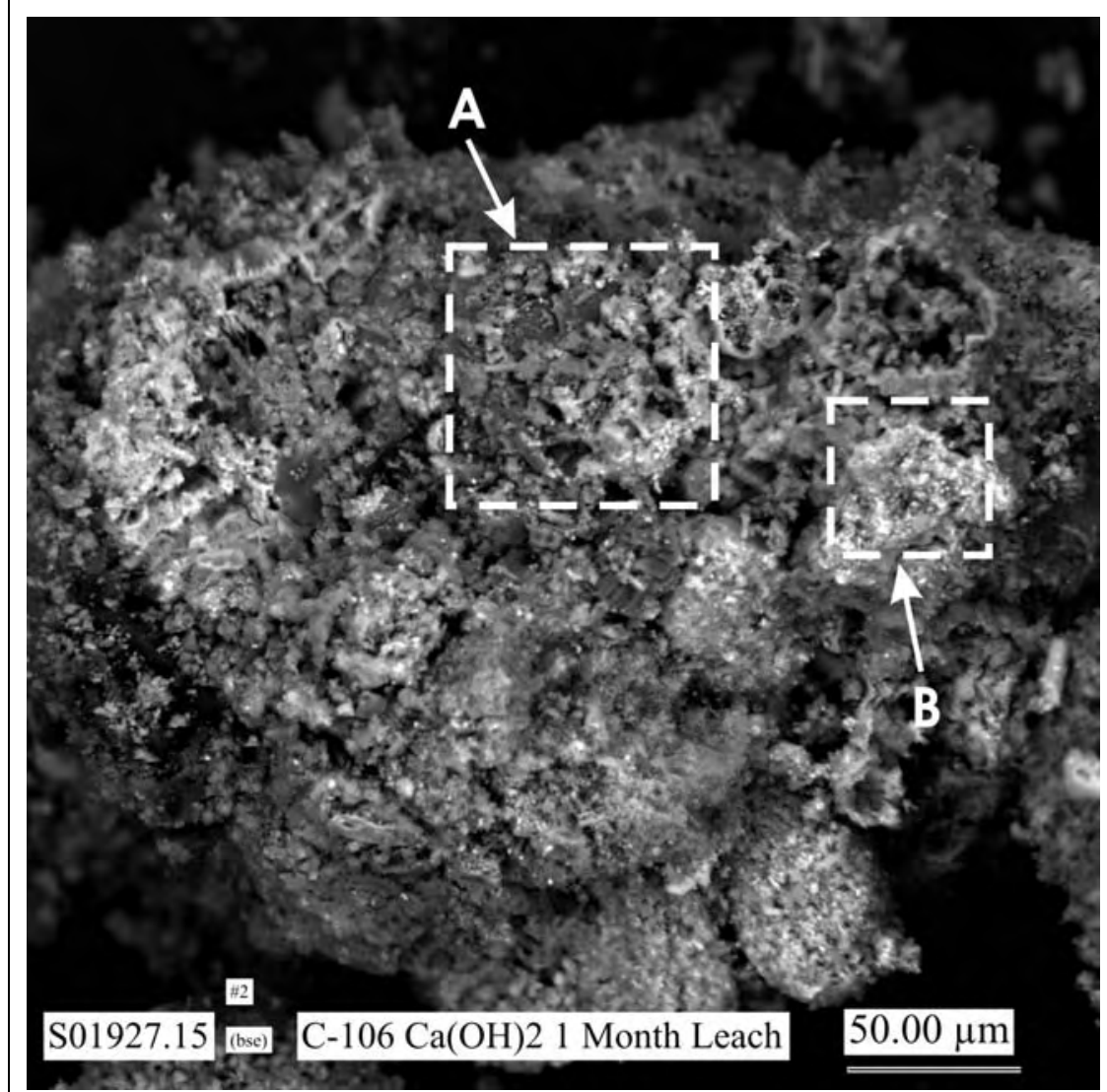

Figure B.15. Micrograph Showing Morphologies of Typical Particles in the SEM Sample of 1-Month $\mathrm{Ca}(\mathrm{OH})_{2}$ Leached Residual Waste from Tank C-106

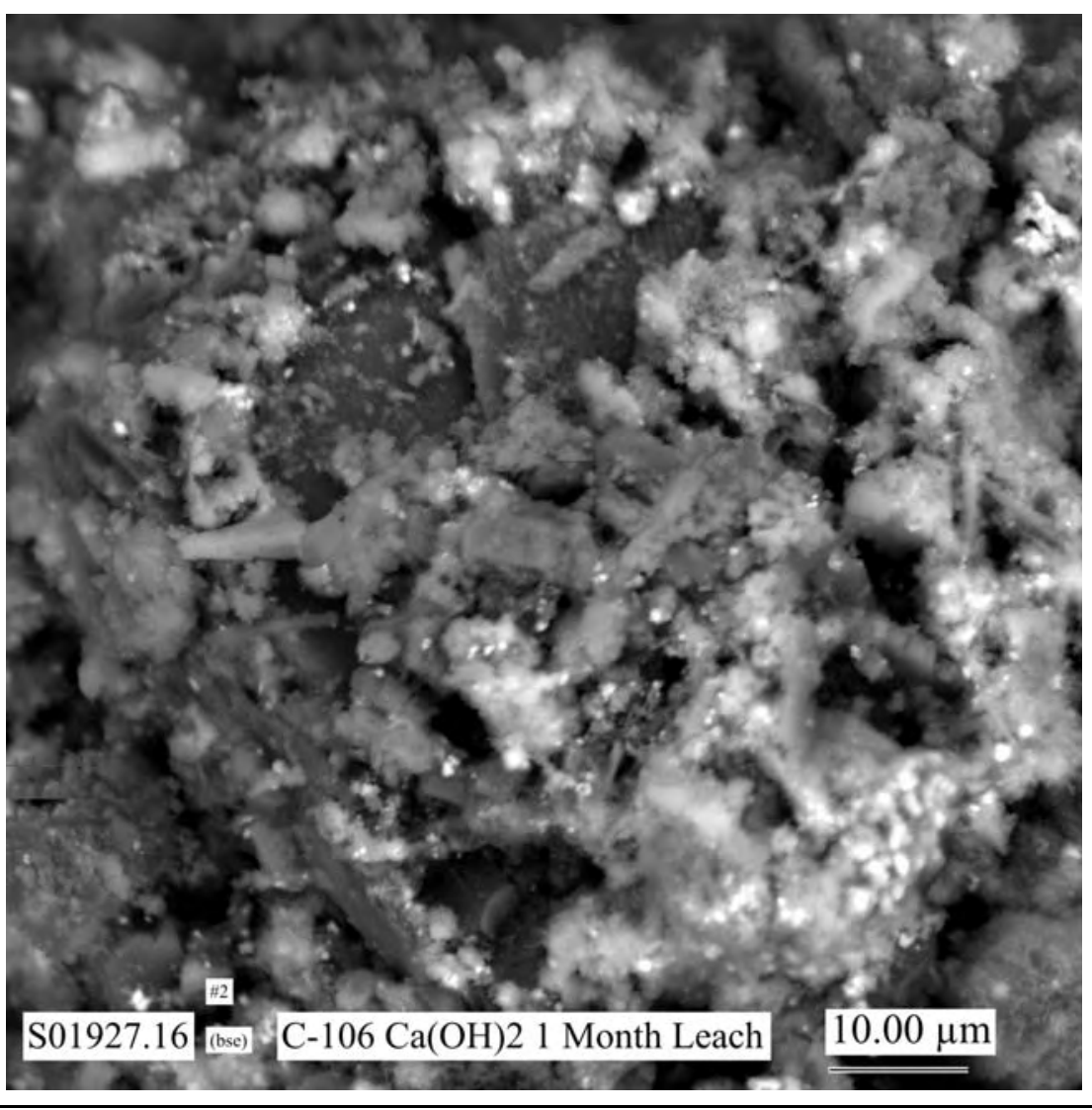

Figure B.16. Micrograph Showing at Higher Magnification the Area Indicated by the White Dashed-Line Square Labeled A in Figure B.13 (areas where EDS analyses were made are shown in Figure B.26) 


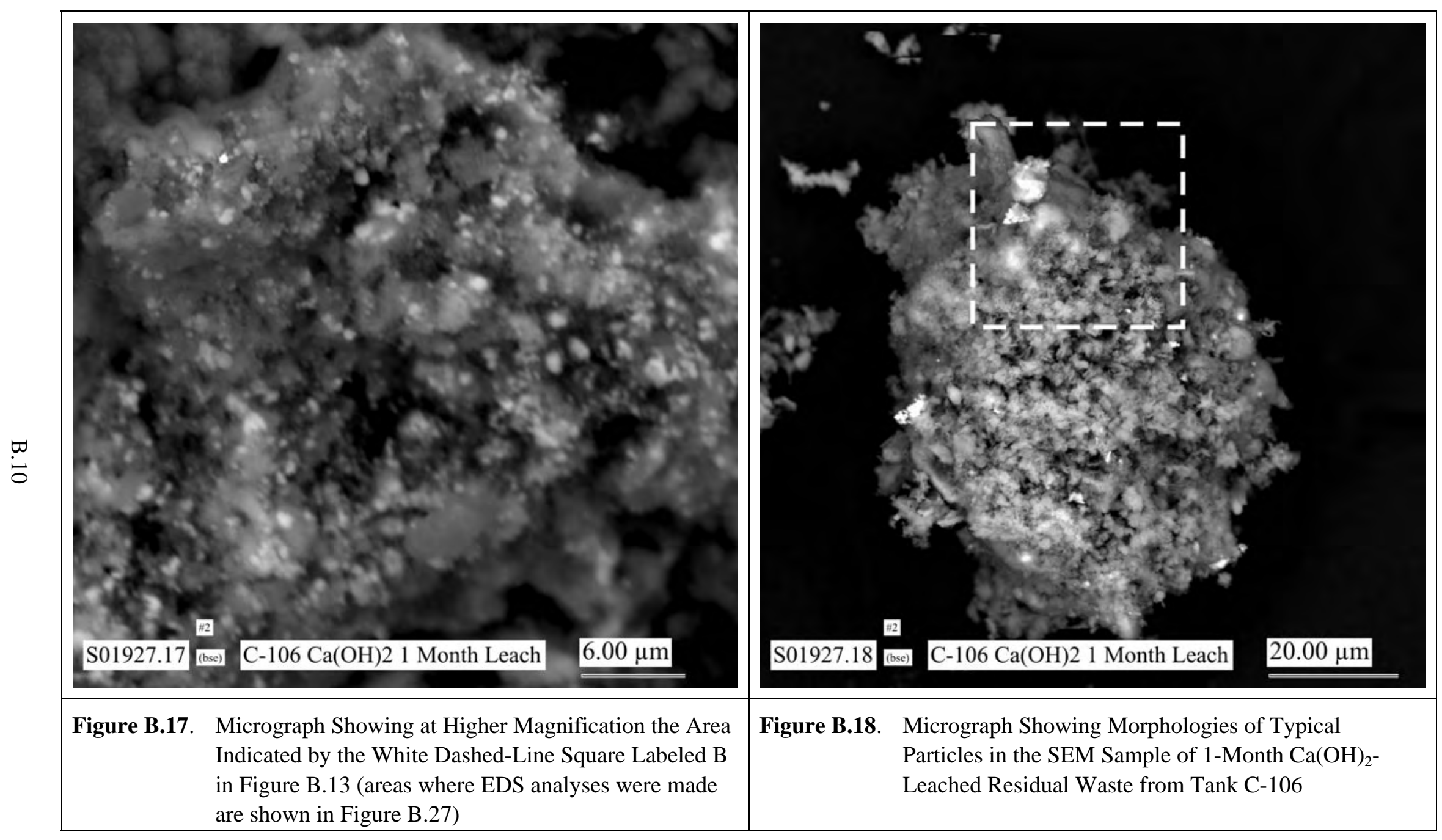




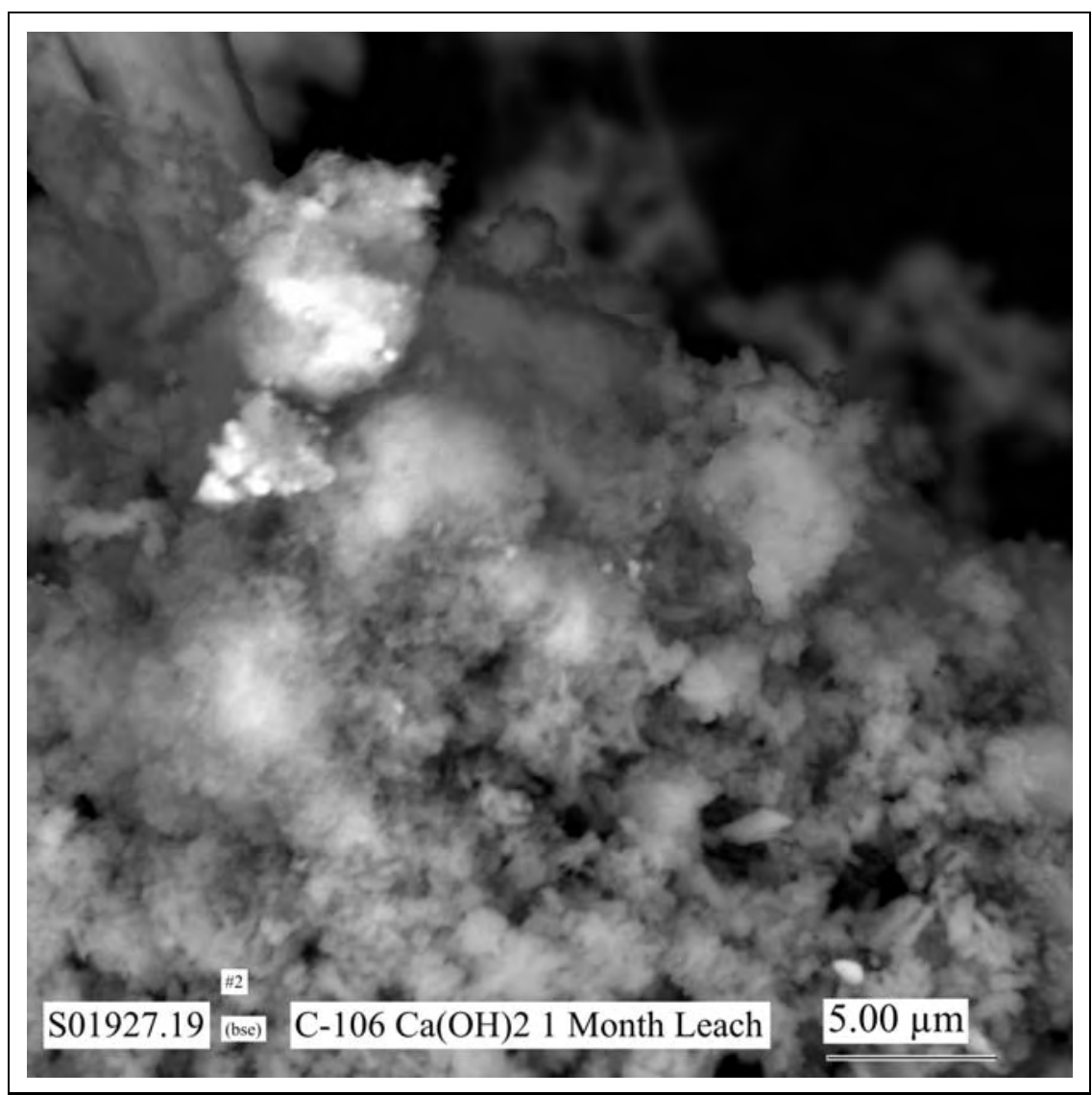

Figure B.19. Micrograph Showing at Higher Magnification the Area Indicated by the White Dashed-Line Square in

Figure B.16 (areas where EDS analyses were made are shown in Figure B.21) 


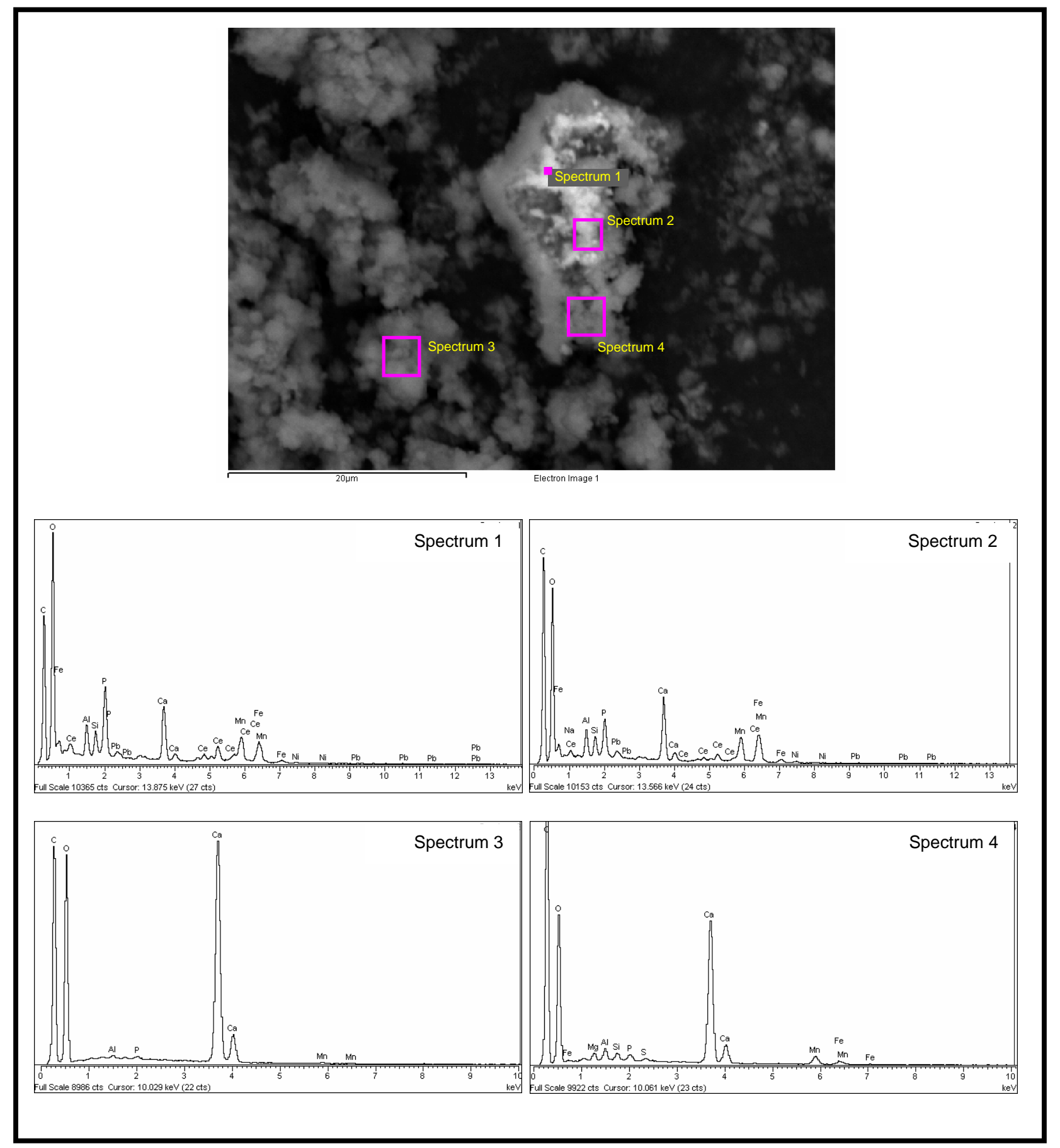

Figure B.20. EDS Spectra for Numbered Areas Marked in Pink in SEM Micrograph Shown at Top of Figure 


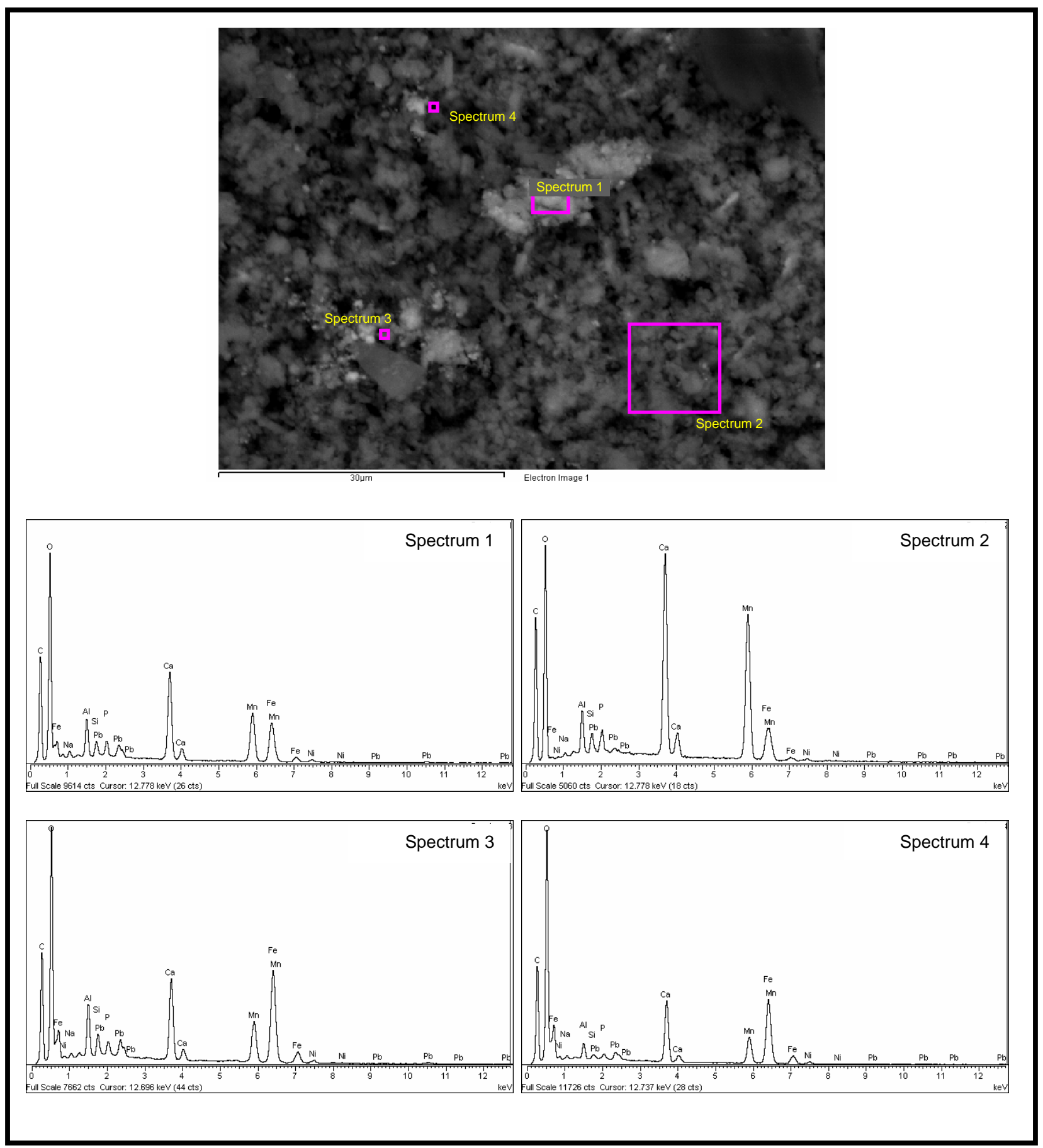

Figure B.21. EDS Spectra for Numbered Areas Marked in Pink in SEM Micrograph Shown at Top of Figure 


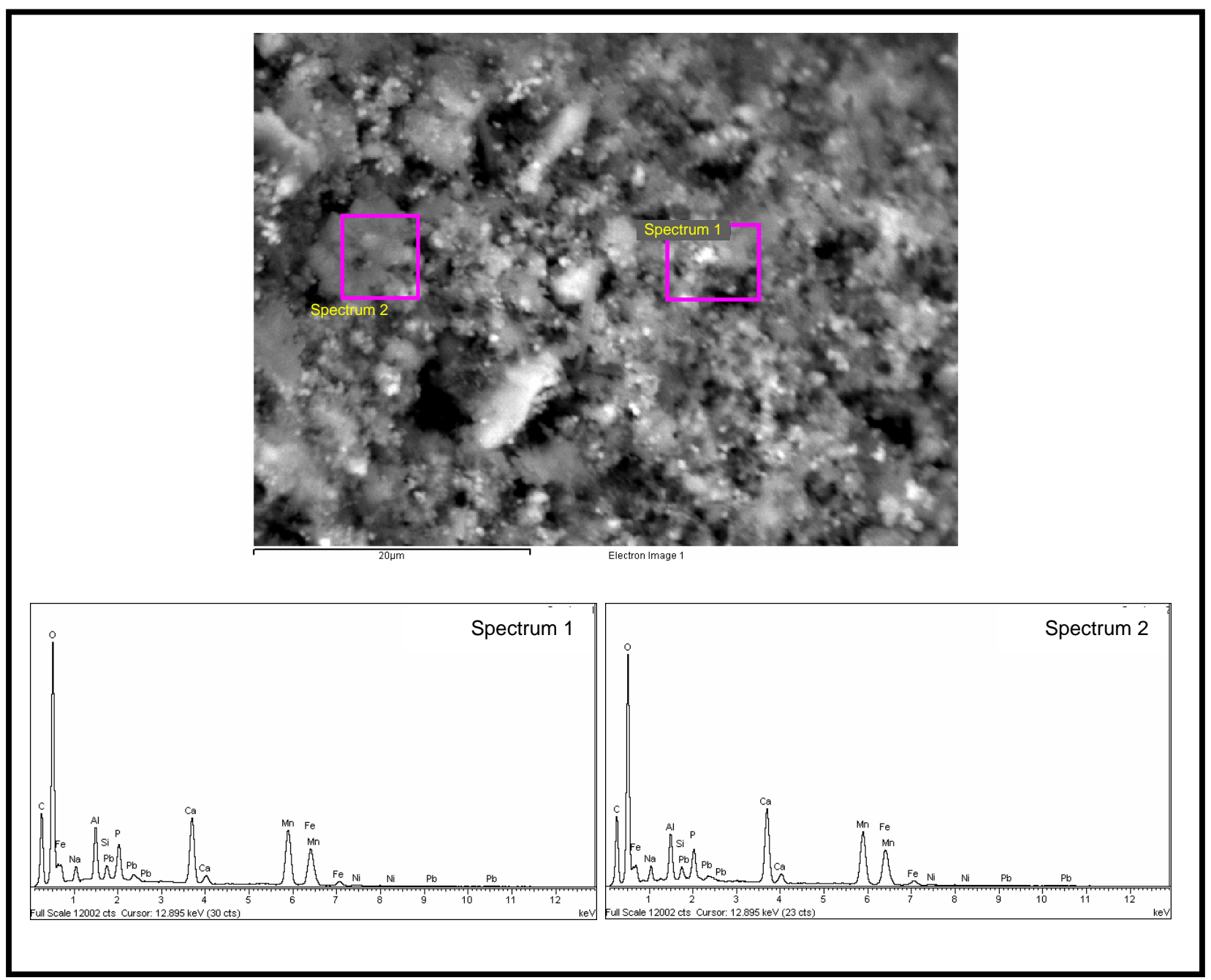

Figure B.22. EDS Spectra for Numbered Areas Marked in Pink in SEM Micrograph Shown at Top of Figure 


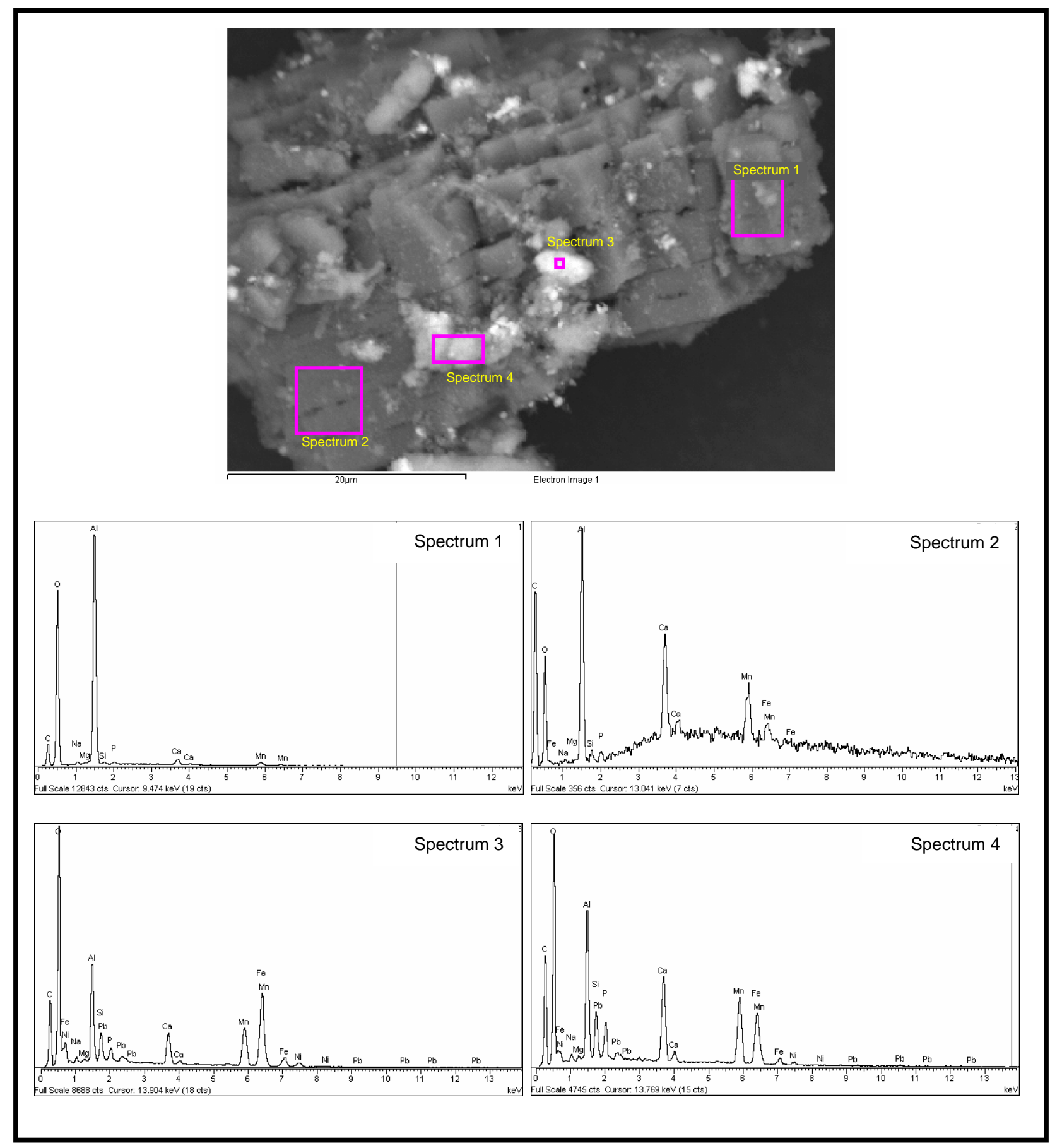

Figure B.23. EDS Spectra for Numbered Areas Marked in Pink in SEM Micrograph Shown at Top of Figure 


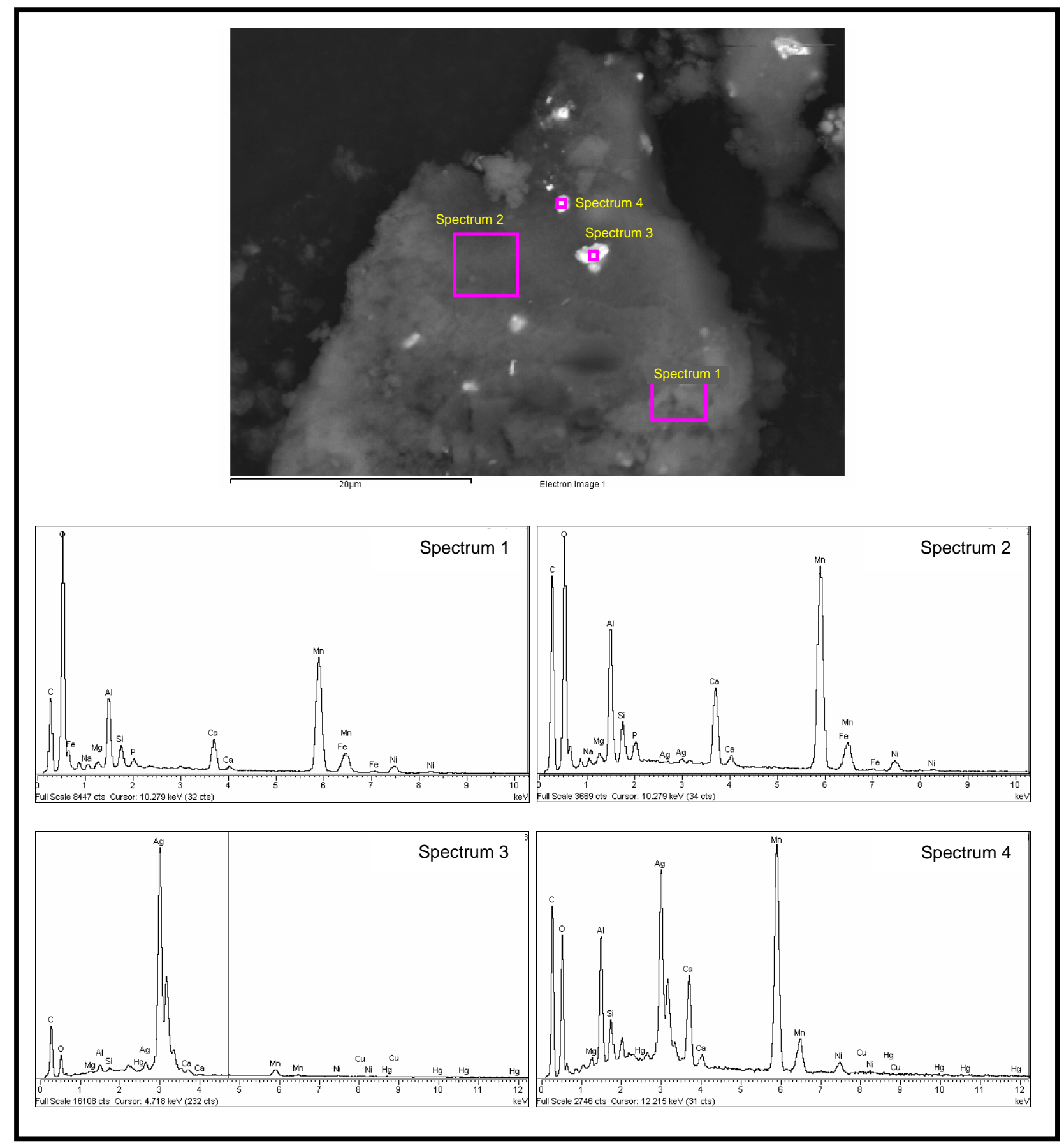

Figure B.24. EDS Spectra for Numbered Areas Marked in Pink in SEM Micrograph Shown at Top of Figure 


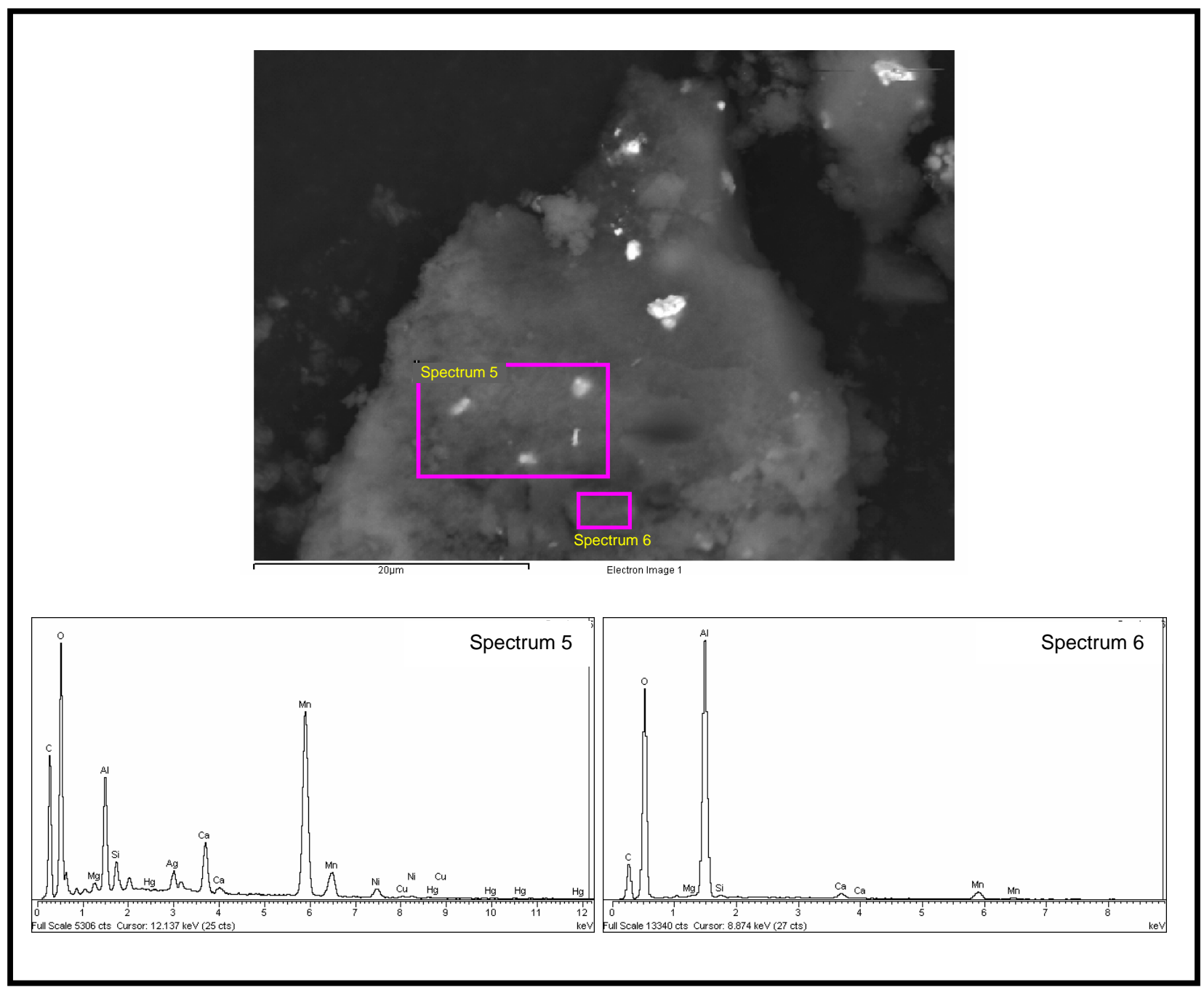

Figure B.25. EDS Spectra for Numbered Areas Marked in Pink in SEM Micrograph Shown at Top of Figure 


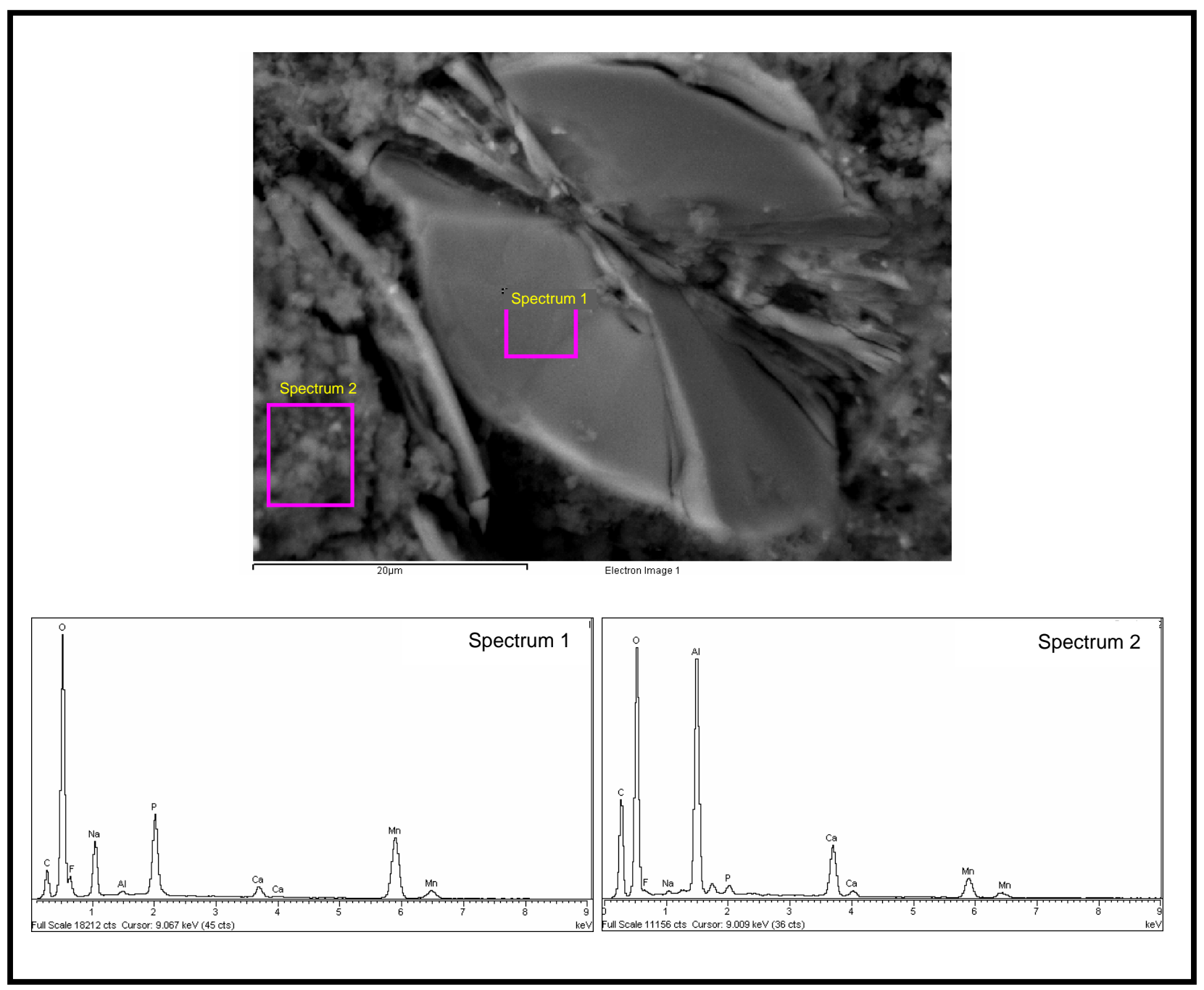

Figure B.26. $\quad$ EDS Spectra for Numbered Areas Marked in Pink in SEM Micrograph Shown at Top of Figure 


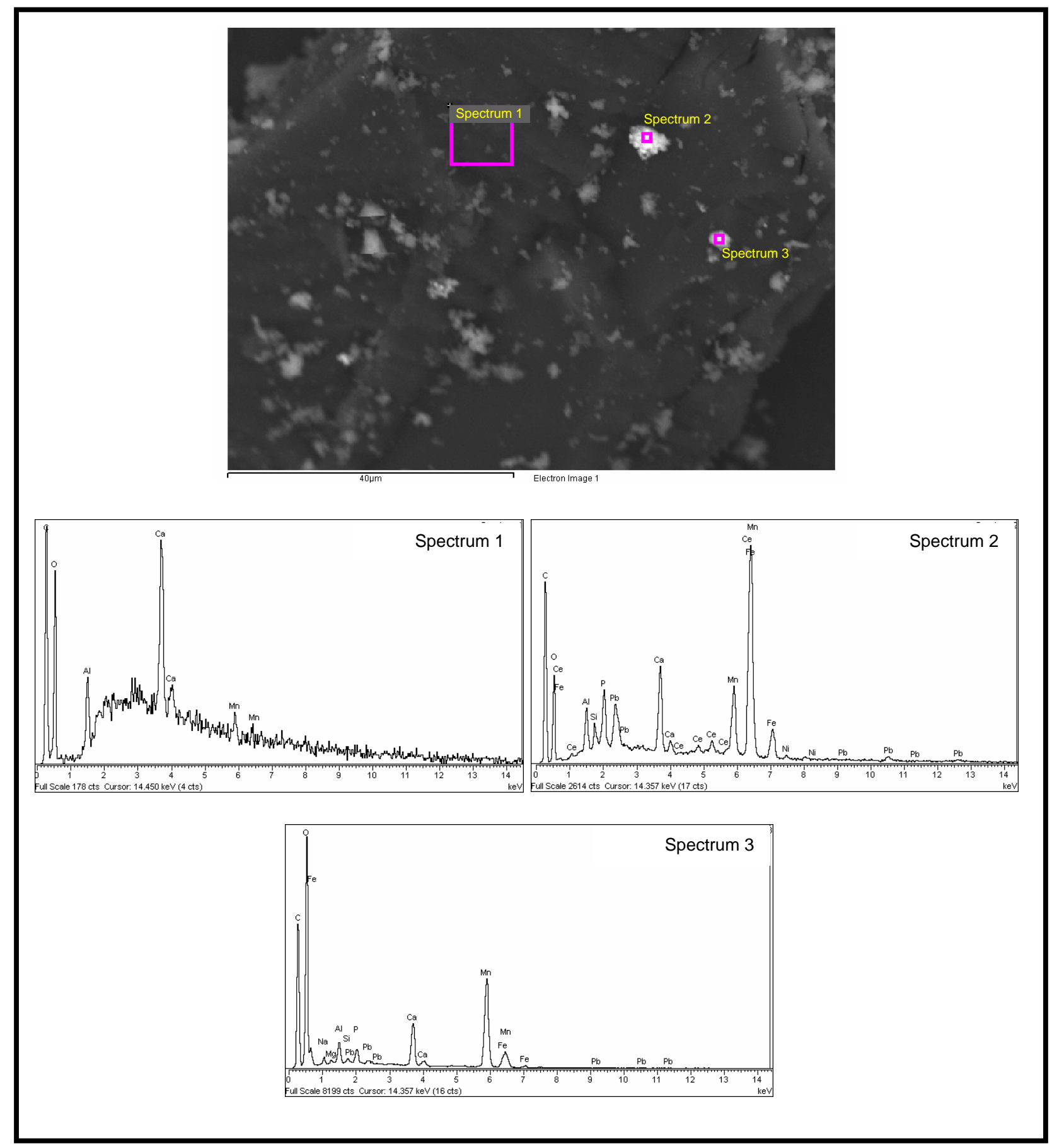

Figure B.27. EDS Spectra for Numbered Areas Marked in Pink in SEM Micrograph Shown at Top of Figure 


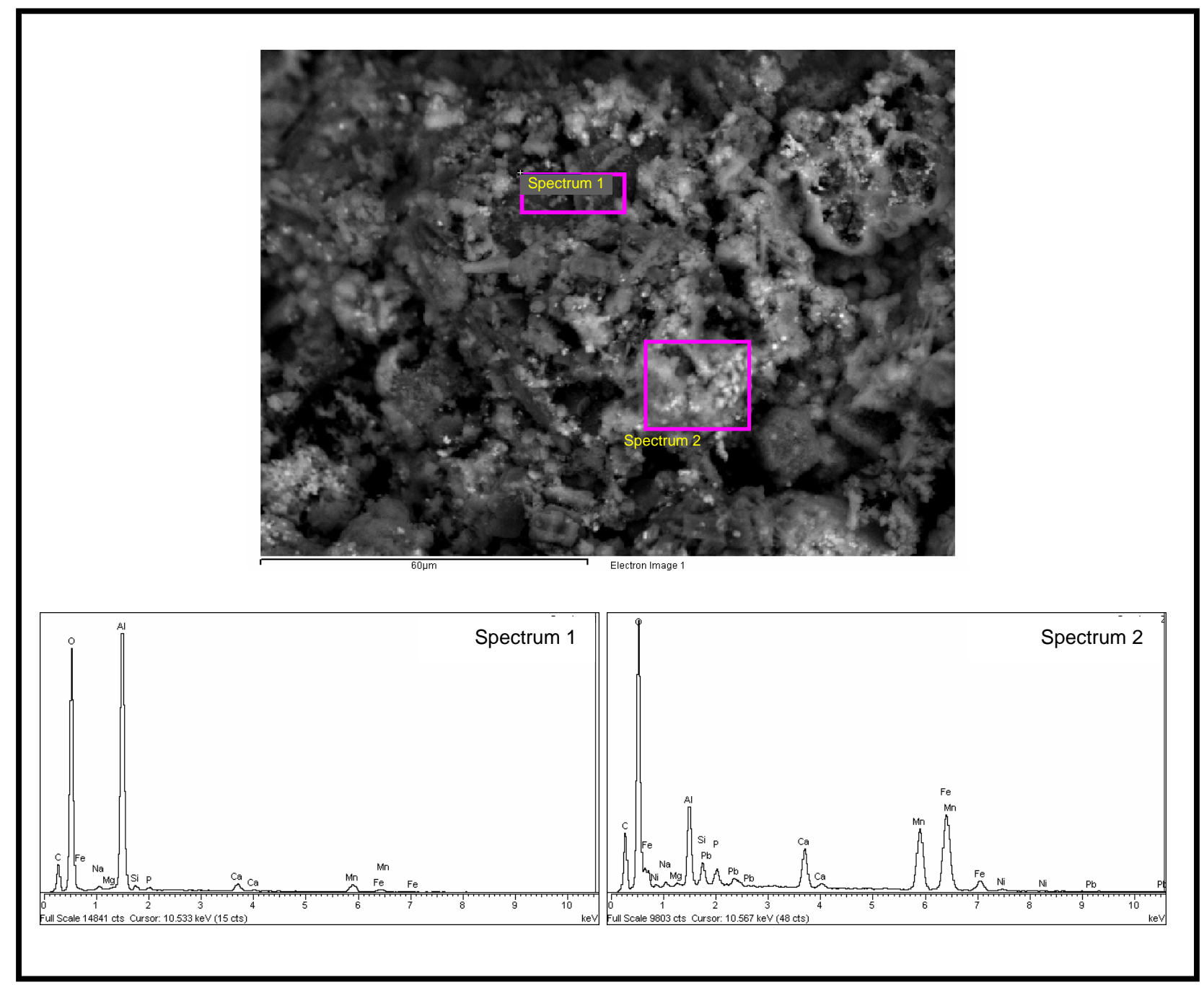

Figure B.28. EDS Spectra for Numbered Areas Marked in Pink in SEM Micrograph Shown at Top of Figure 


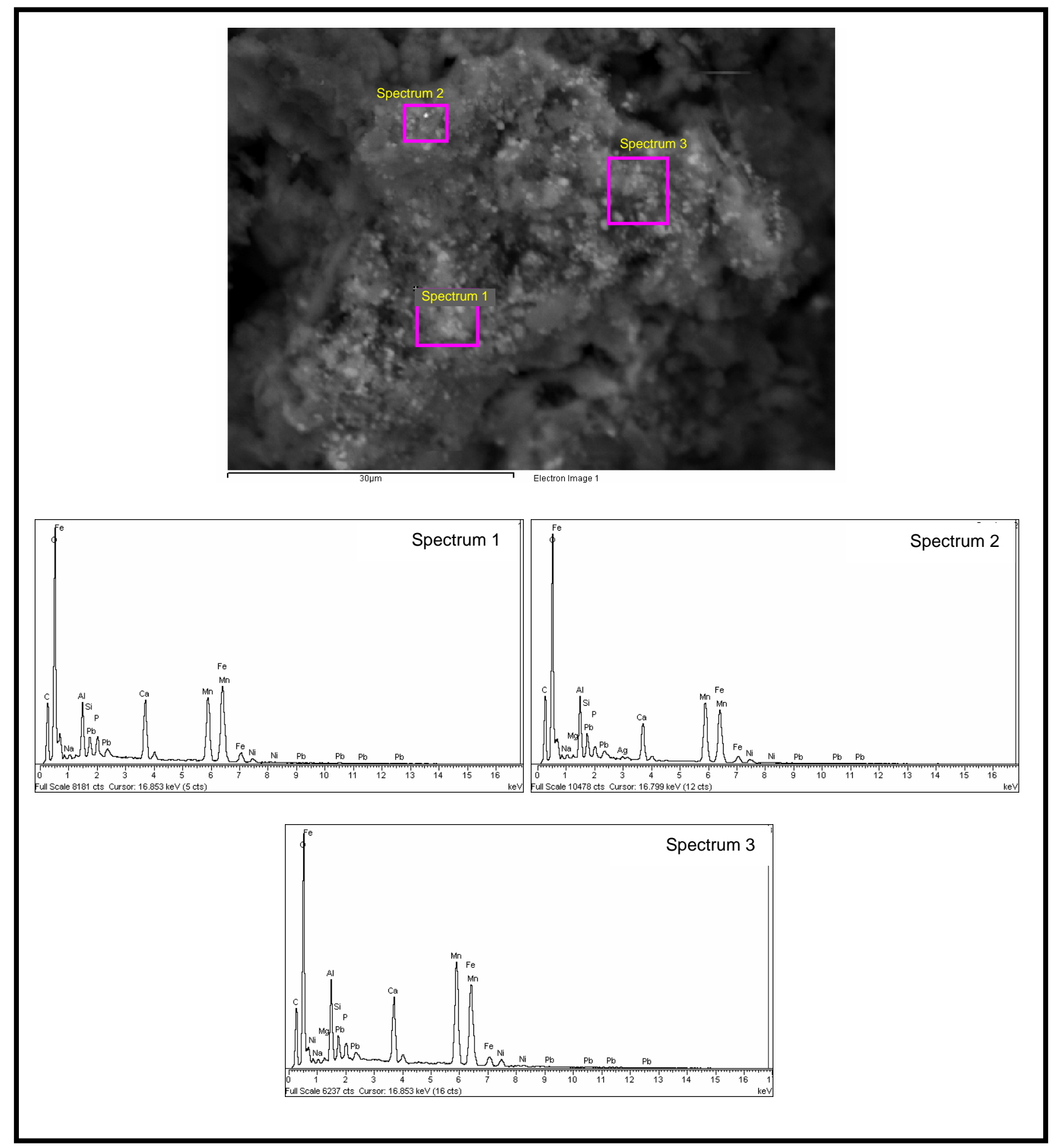

Figure B.29. EDS Spectra for Numbered Areas Marked in Pink in SEM Micrograph Shown at Top of Figure 


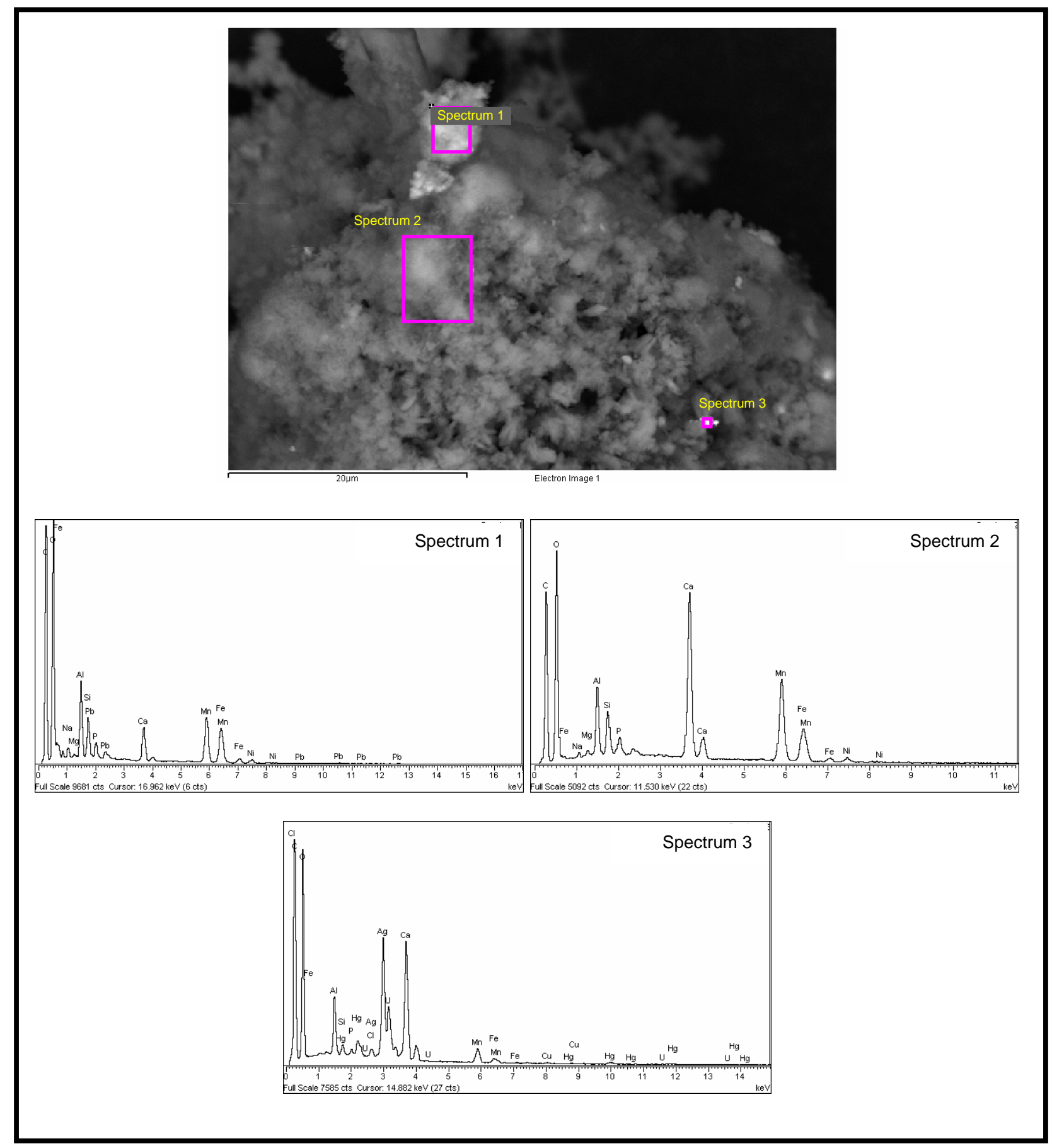

Figure B.30. EDS Spectra for Numbered Areas Marked in Pink in SEM Micrograph Shown at Top of Figure 


\section{Appendix C}

\section{SEM Micrographs and EDS Results for Stage 6 Sequential $\mathrm{Ca}(\mathrm{OH})_{2}$-Leached Tank C-106 Residual Waste}




\section{Appendix C}

\section{SEM Micrographs and EDS Results for Stage 6 Sequential $\mathrm{Ca}(\mathrm{OH})_{2}$-Leached Tank C-106 Residual Waste}

This appendix includes the scanning electron microscope (SEM) micrographs and the energydispersive x-ray spectrometry (EDS) spectra, and element-distribution maps for samples of Stage 6 sequential $\mathrm{Ca}(\mathrm{OH})_{2}$-leached residual waste from tank $\mathrm{C}-106$. The operating conditions for the SEM and procedures used for mounting the SEM samples are described in Section 3.4 of the main report.

The identification number for the digital micrograph image file, descriptor for the type of sample, and a size scale bar are given, respectively, at the bottom left, center, and right of each SEM micrograph in this appendix. Micrographs labeled by "BSE" to the immediate right of the digital image file number indicate that the micrograph was collected with backscattered electrons. Sample areas or particles identified by a letter, arrow, and/or outlined by a white or black dotted-line squares in a micrograph designate sample material that was imaged at higher magnification, which is typically shown in figure(s) that immediately follow in the series for that sample. The SEM micrographs for this leached material are shown in Figures C.1 through C.12. The EDS spectra for this mount are given in Figures C.13 through C.23. 

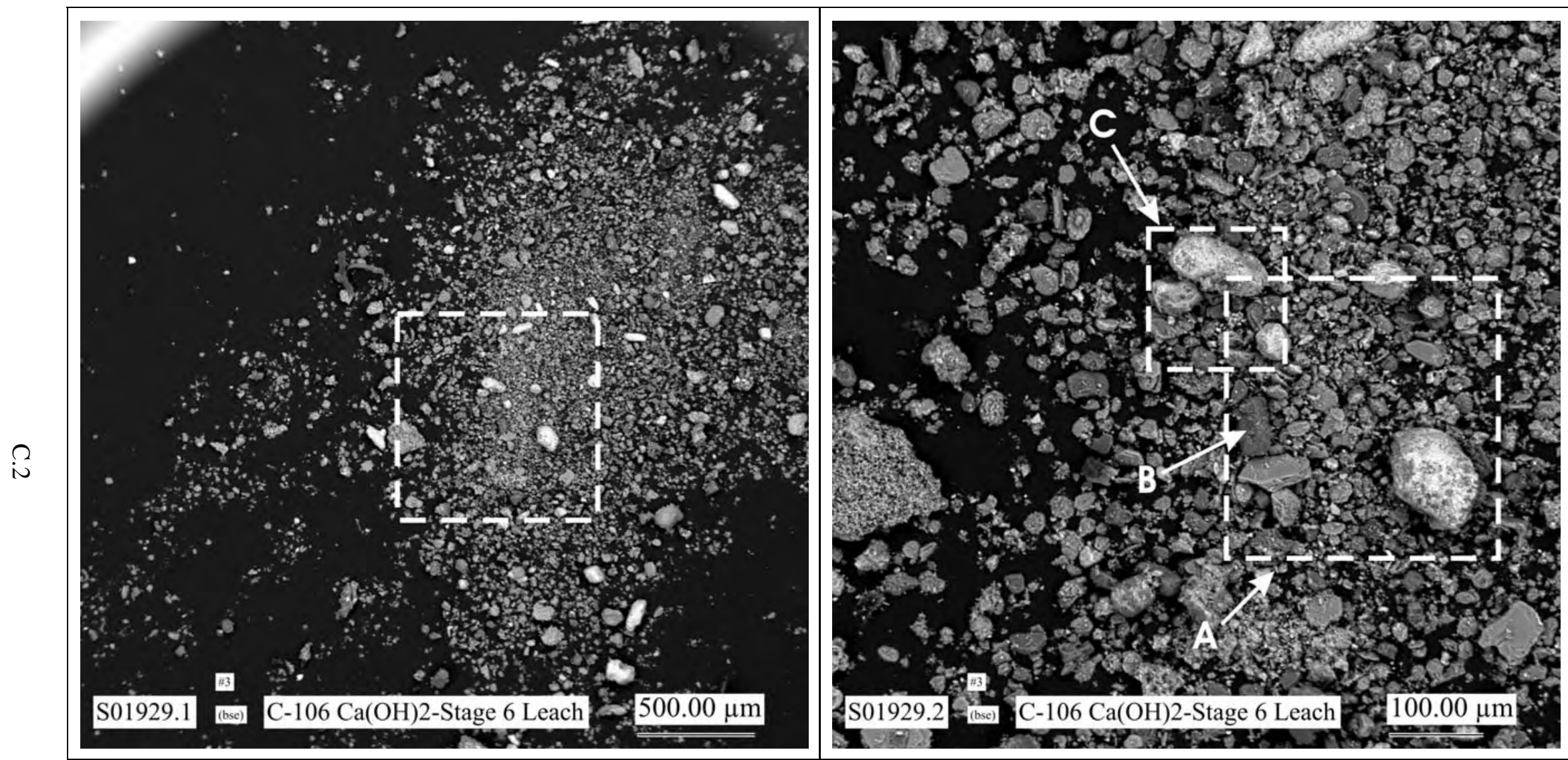

Figure C.1. Low Magnification SEM Micrograph Showing General Morphologies of Particles in the SEM Sample of the Stage 6 Sequential $\mathrm{Ca}(\mathrm{OH})_{2}$-Leached Residual Waste

Figure C.2. Micrograph Showing at Higher Magnification the Particles in the Area Indicated by the White DashedLine Square in Figure C.1 from Tank C-106 


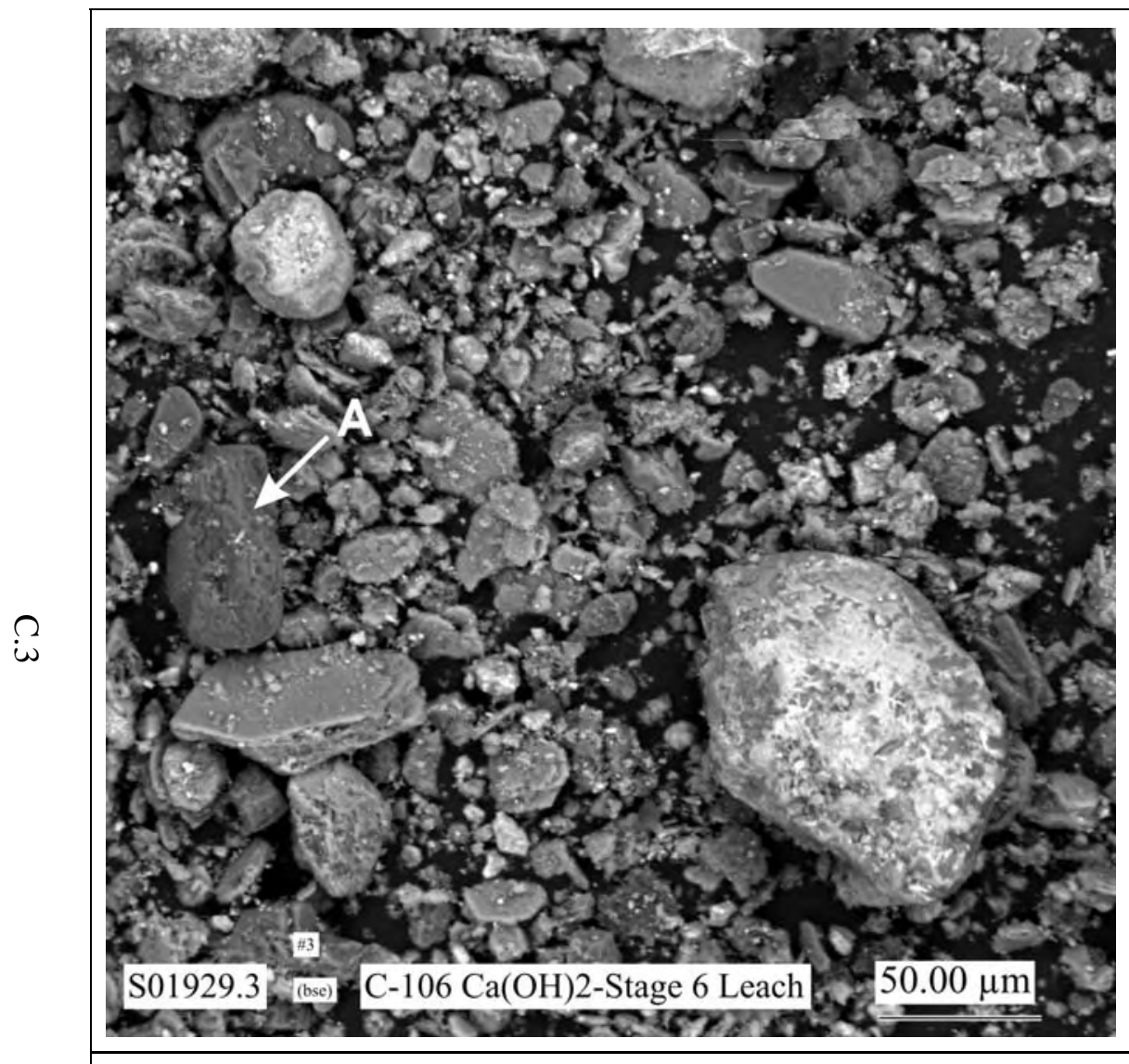

Figure C.3. Micrograph Showing at Higher Magnification the Particles in the Area Indicated by the White DashedLine Square Labeled A in Figure C.2 (particles in upper right of this figure where EDS analyses were made are shown in Figures C.14 and C.15)

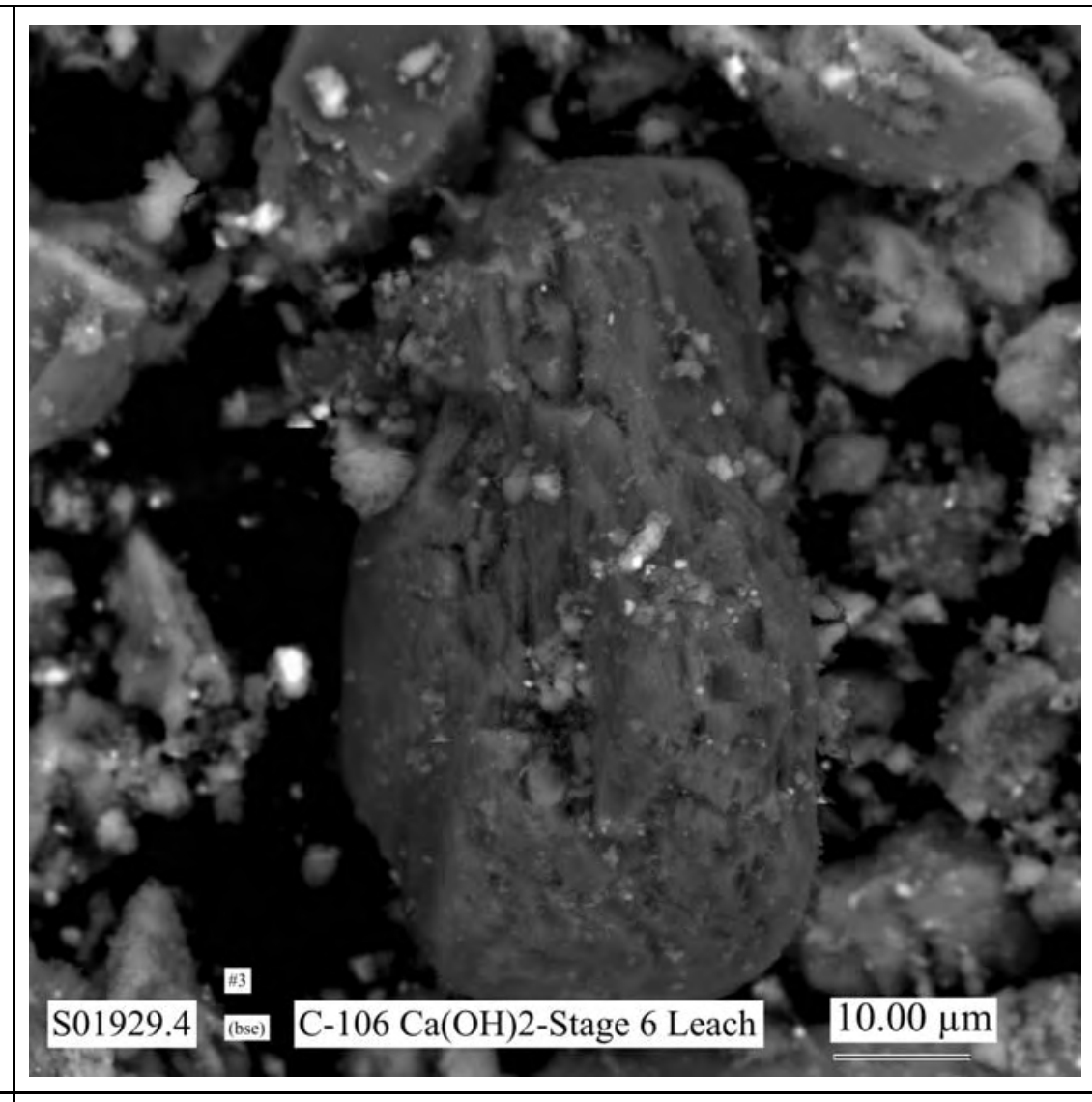

Figure C.4. Micrograph Showing at Higher Magnification the Particle Labeled B in Figure C.2 and A in Figure C.3 (areas where EDS analyses were made are shown in Figure C.13) 


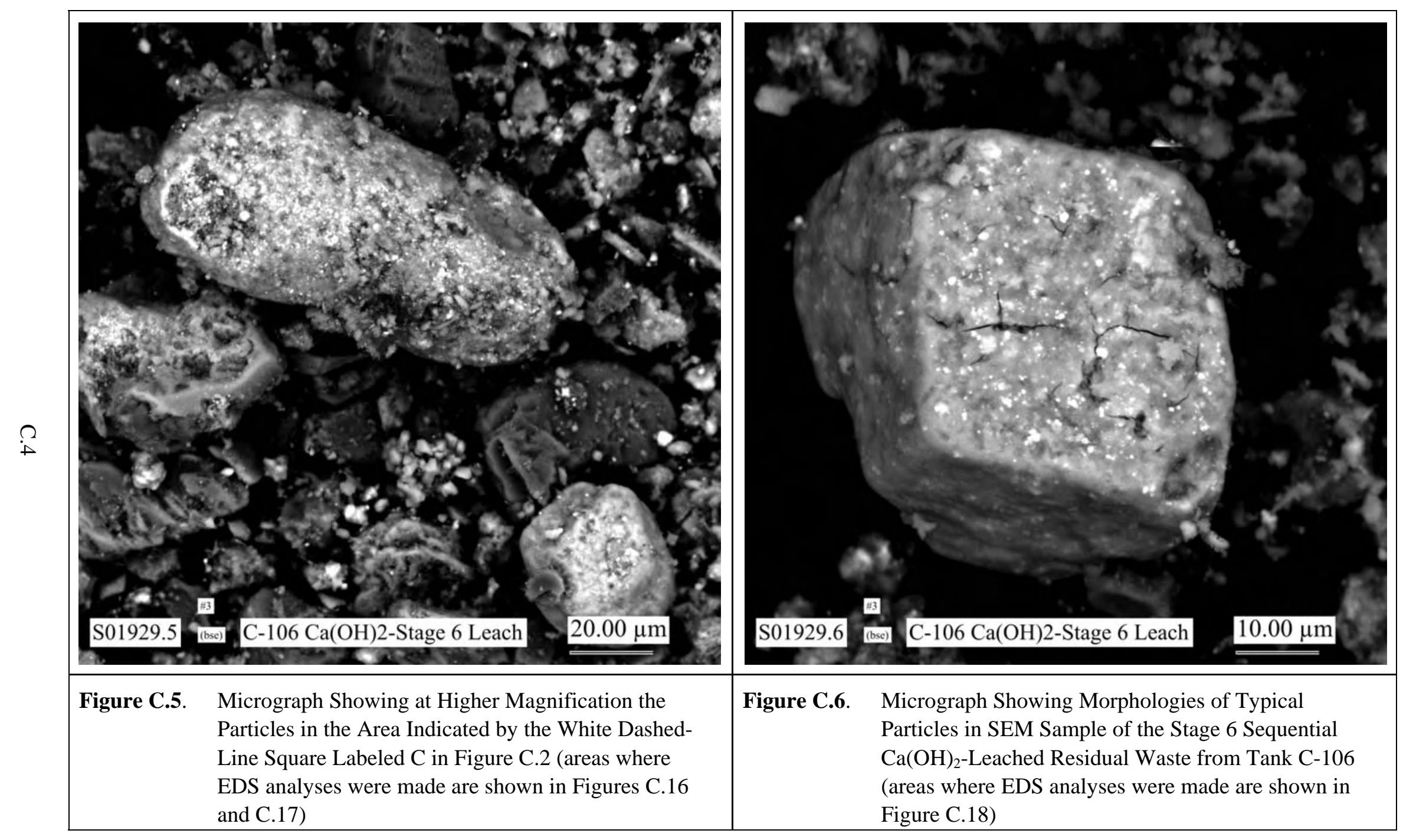




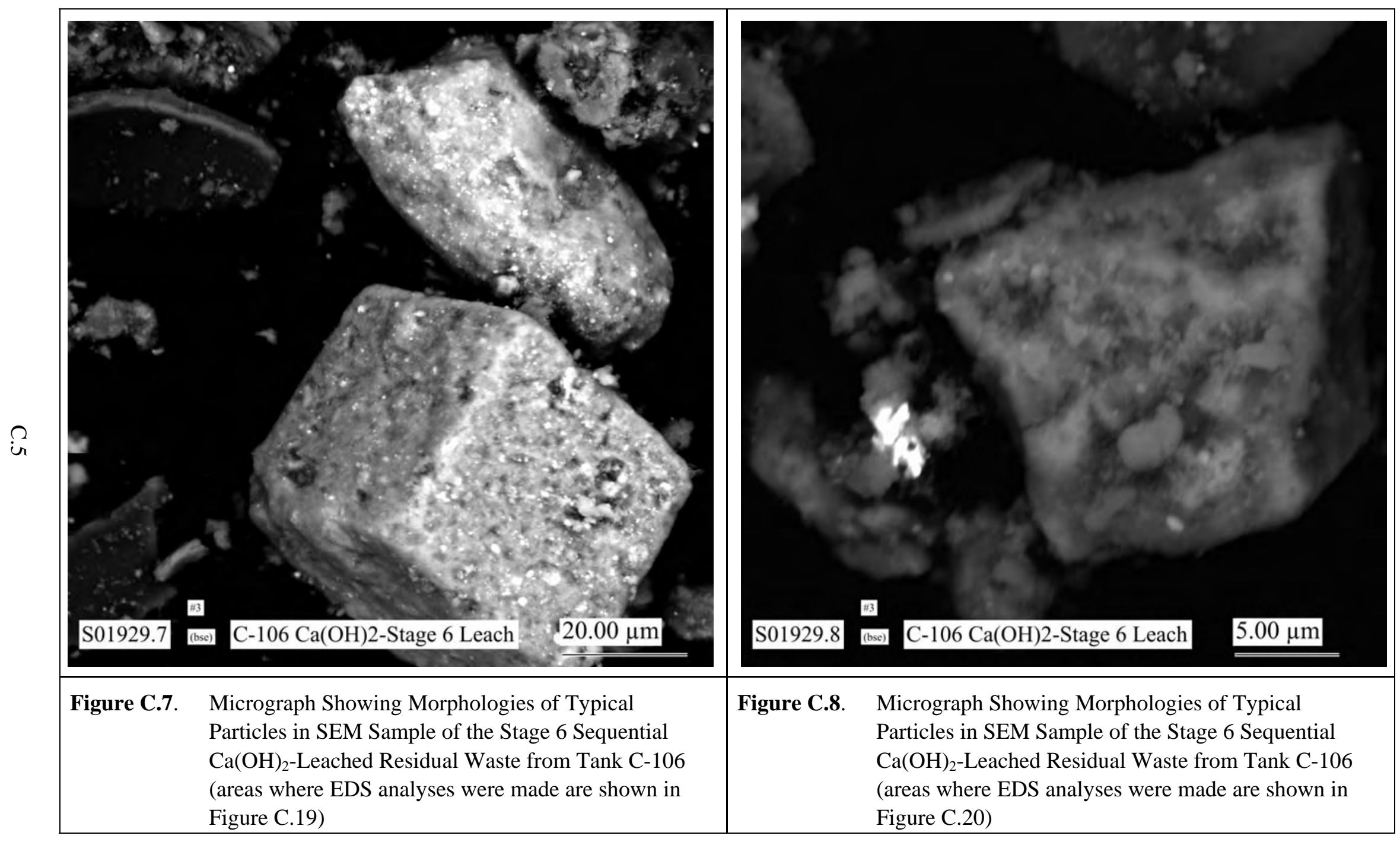




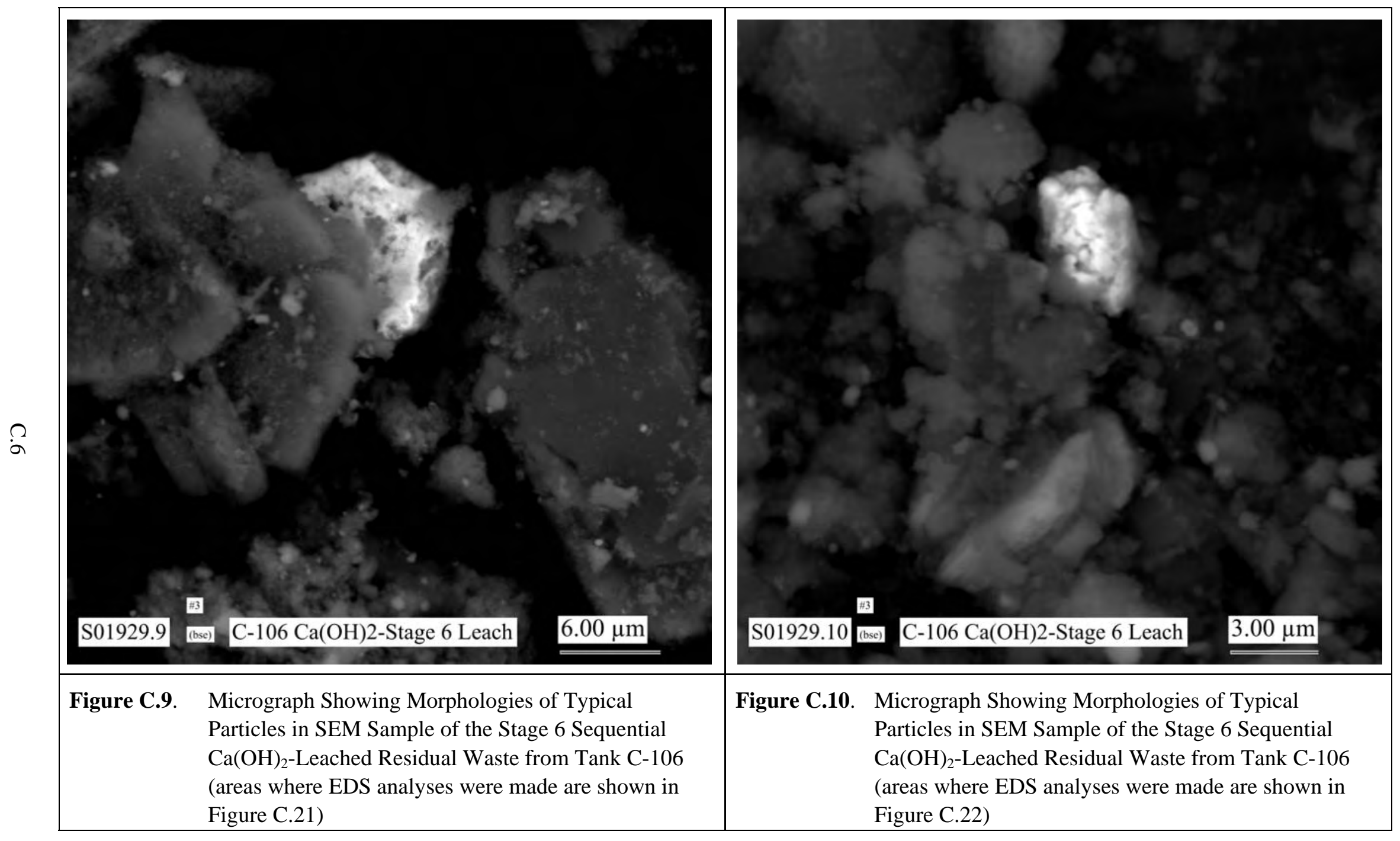




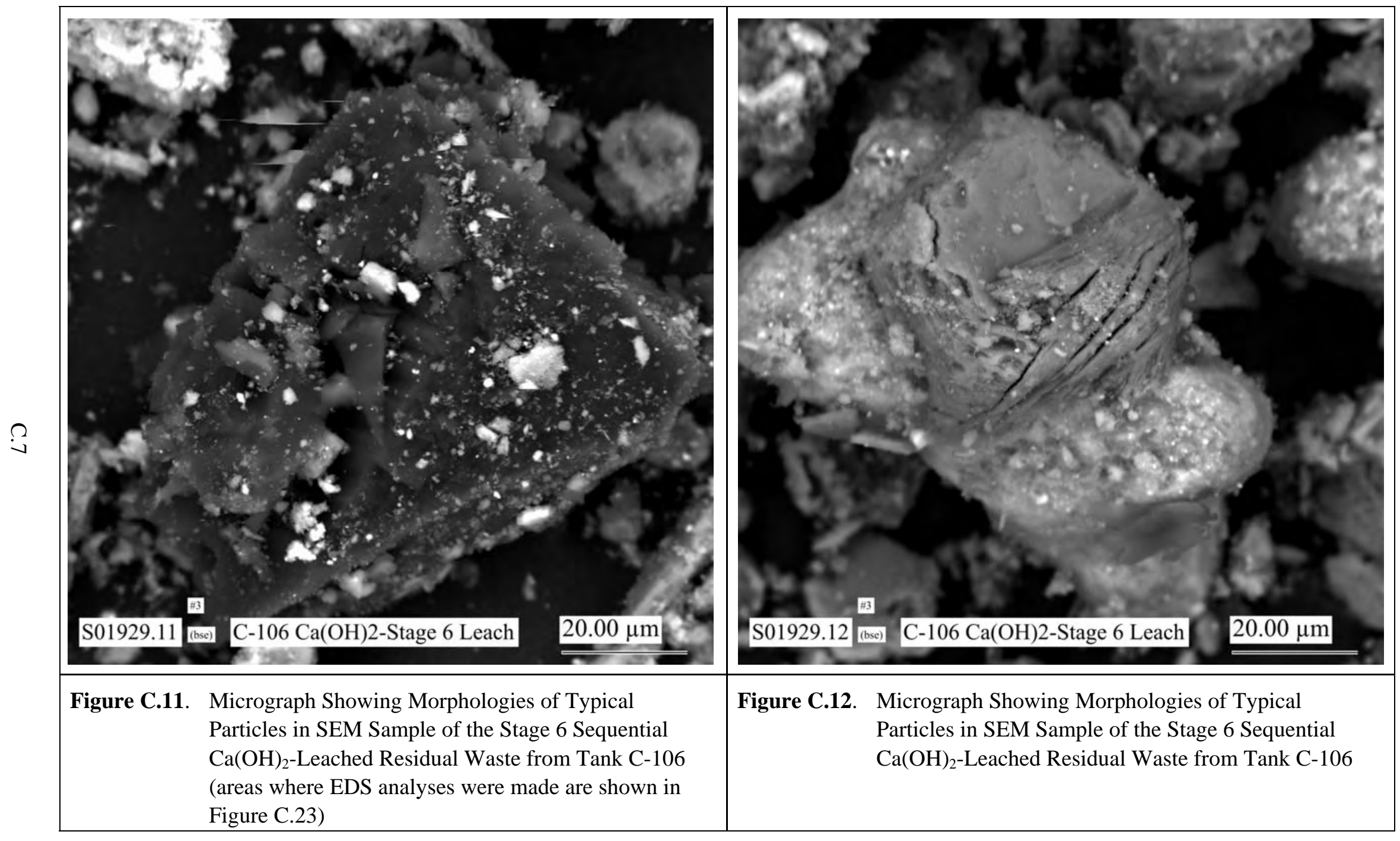




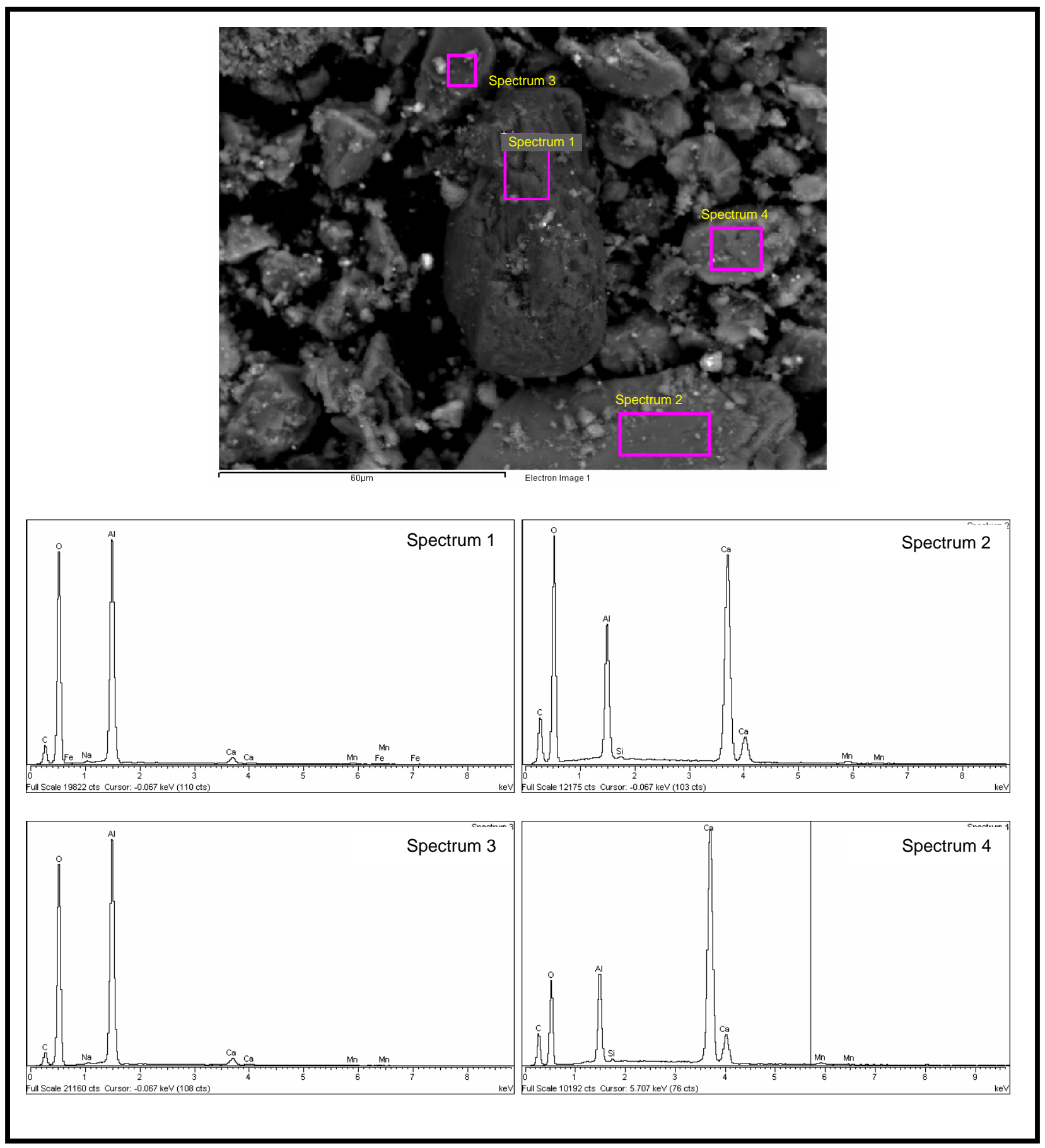

Figure C.13. EDS Spectra for Numbered Areas Marked in Pink in SEM Micrograph Shown at Top of Figure 


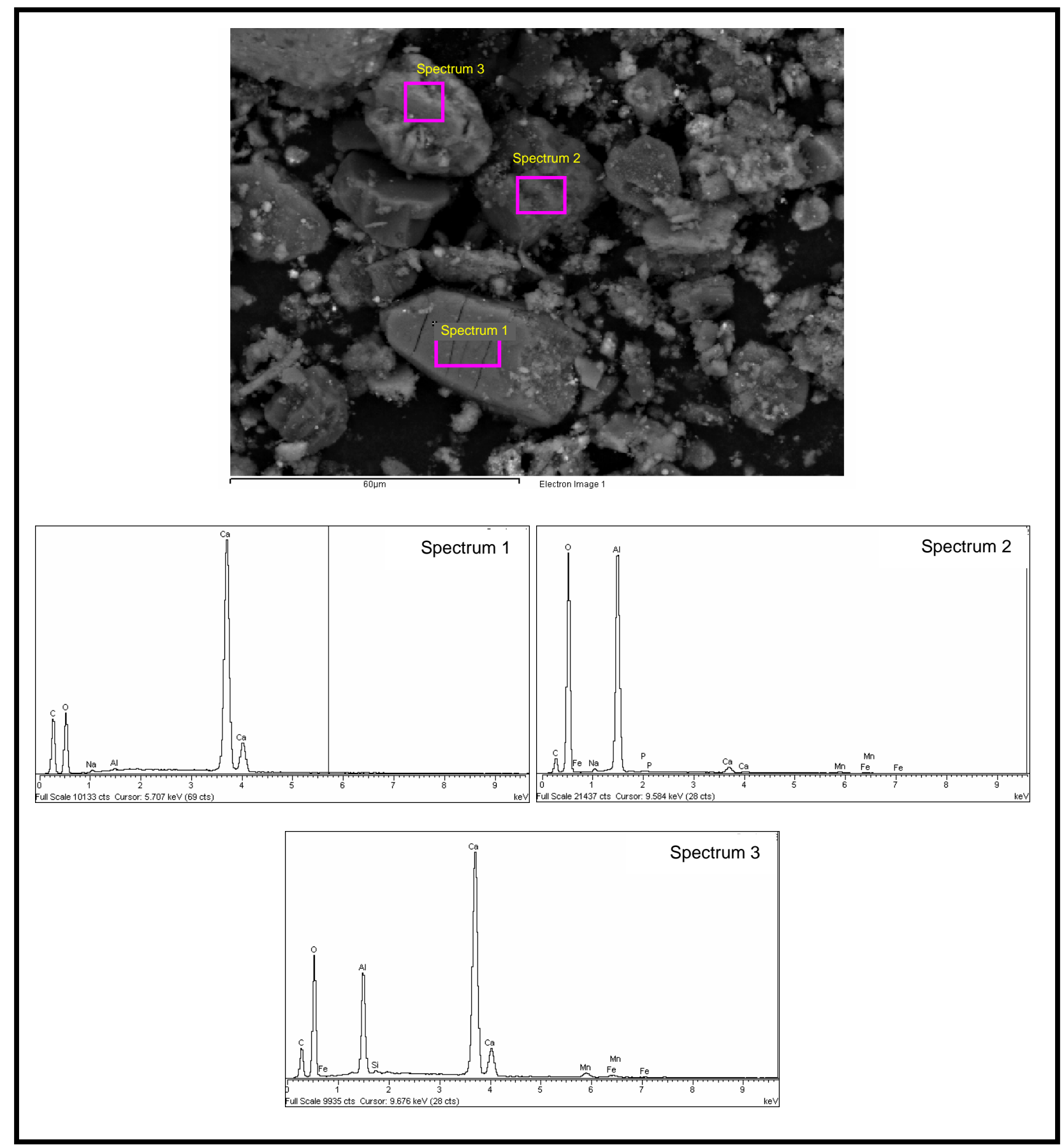

Figure C.14. EDS Spectra for Numbered Areas Marked in Pink in SEM Micrograph Shown at Top of Figure 


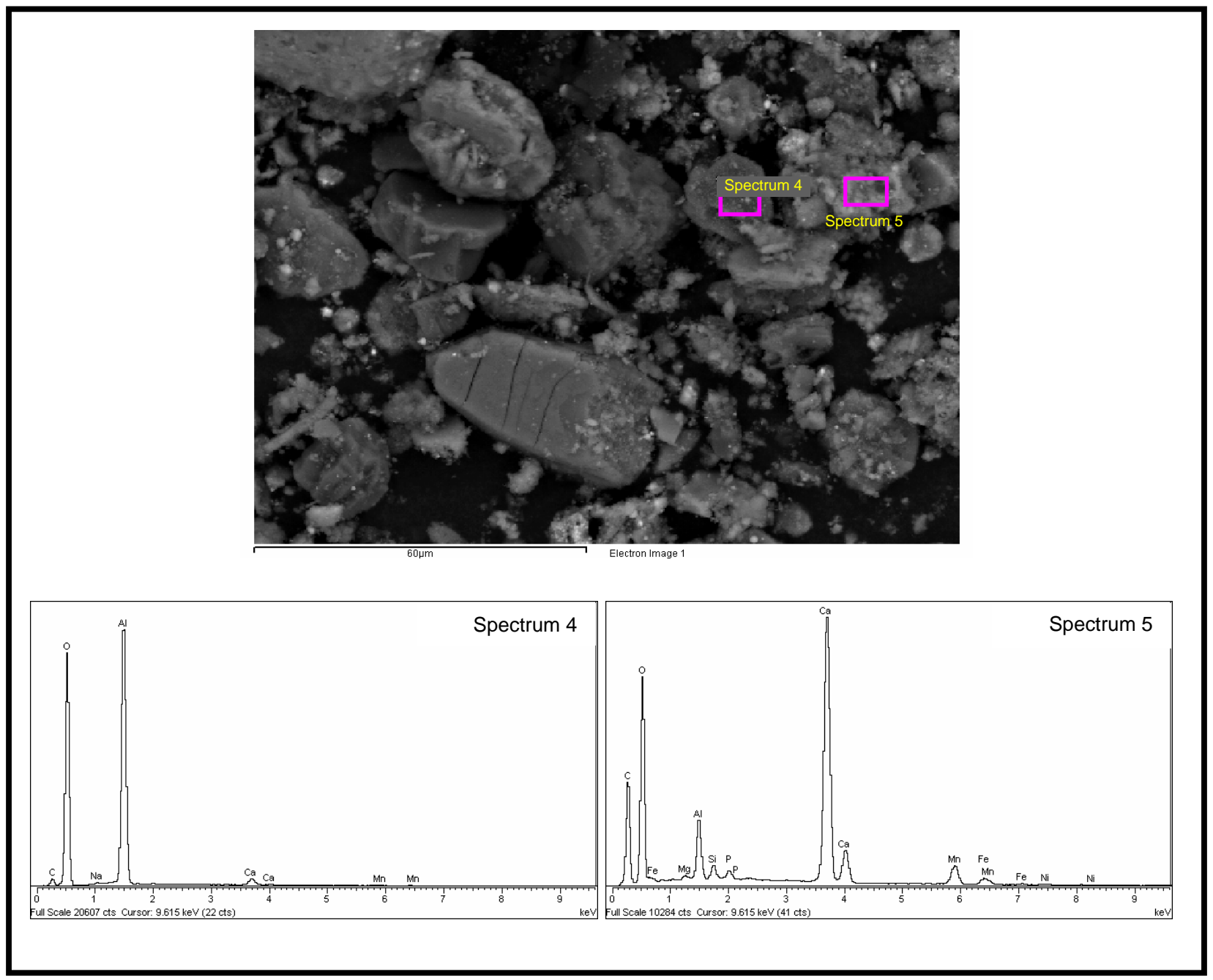

Figure C.15. EDS Spectra for Numbered Areas Marked in Pink in SEM Micrograph Shown at Top of Figure 


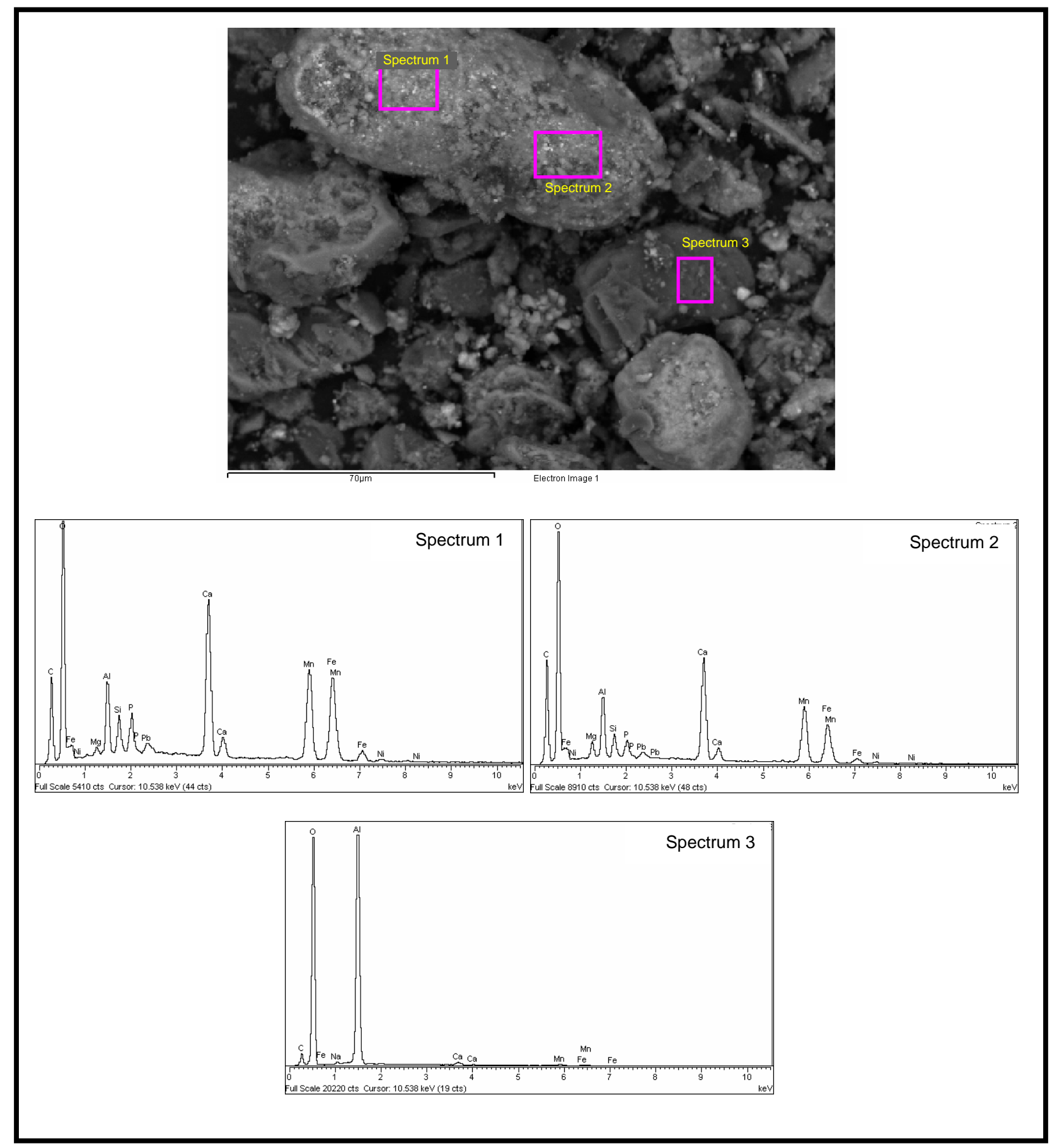

Figure C.16. EDS Spectra for Numbered Areas Marked in Pink in SEM Micrograph Shown at Top of Figure 


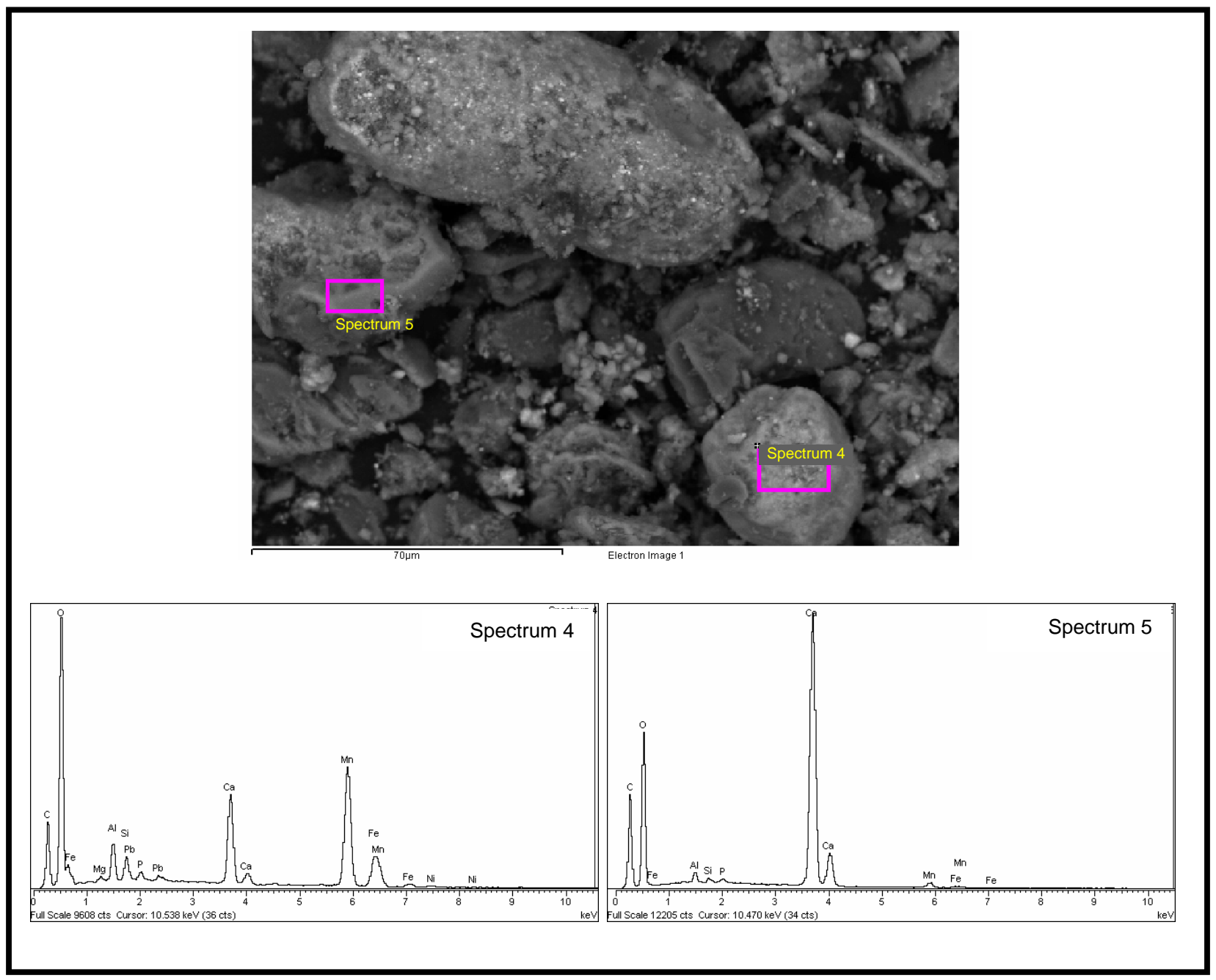

Figure C.17. EDS Spectra for Numbered Areas Marked in Pink in SEM Micrograph Shown at Top of Figure 


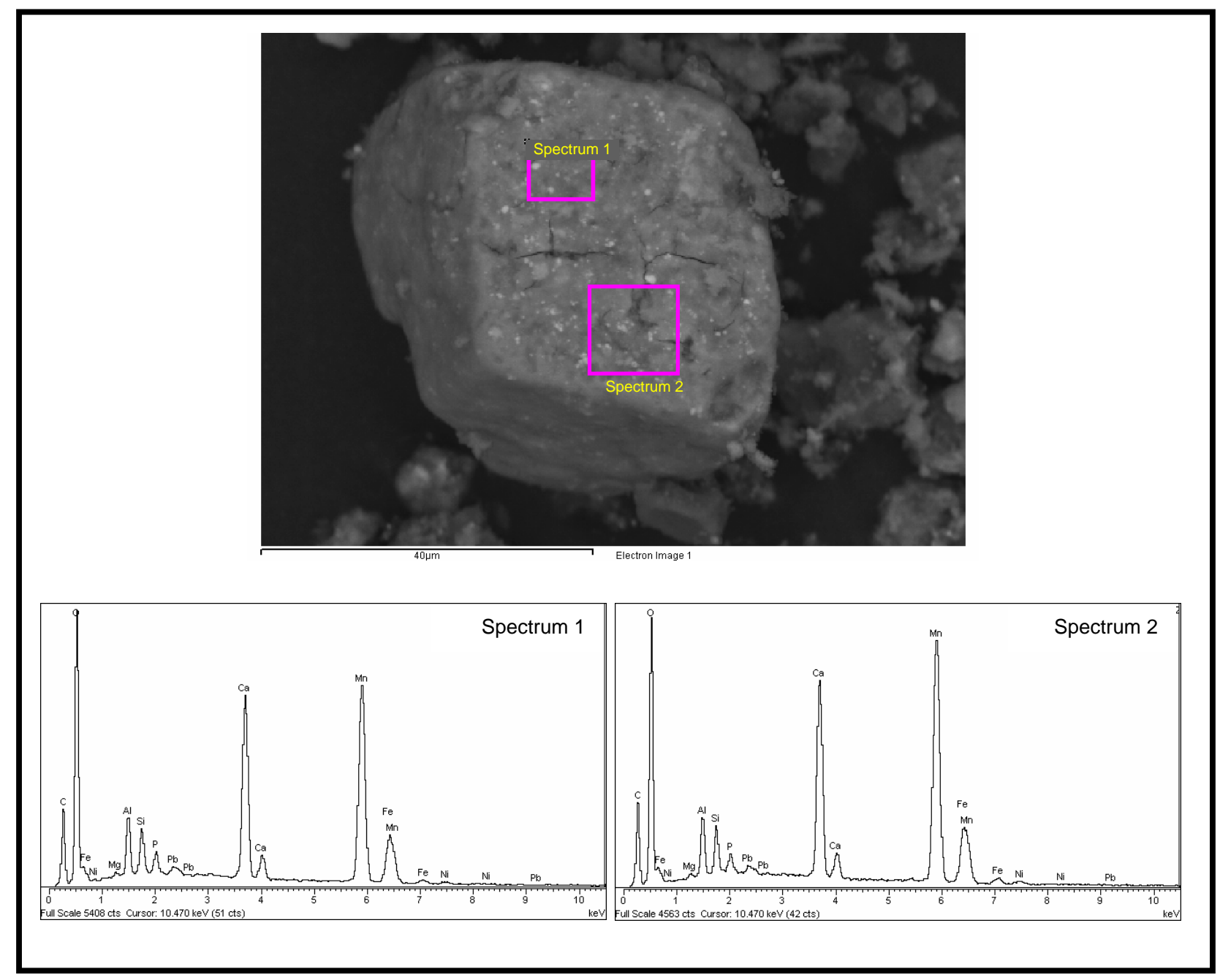

Figure C.18. EDS Spectra for Numbered Areas Marked in Pink in SEM Micrograph Shown at Top of Figure 


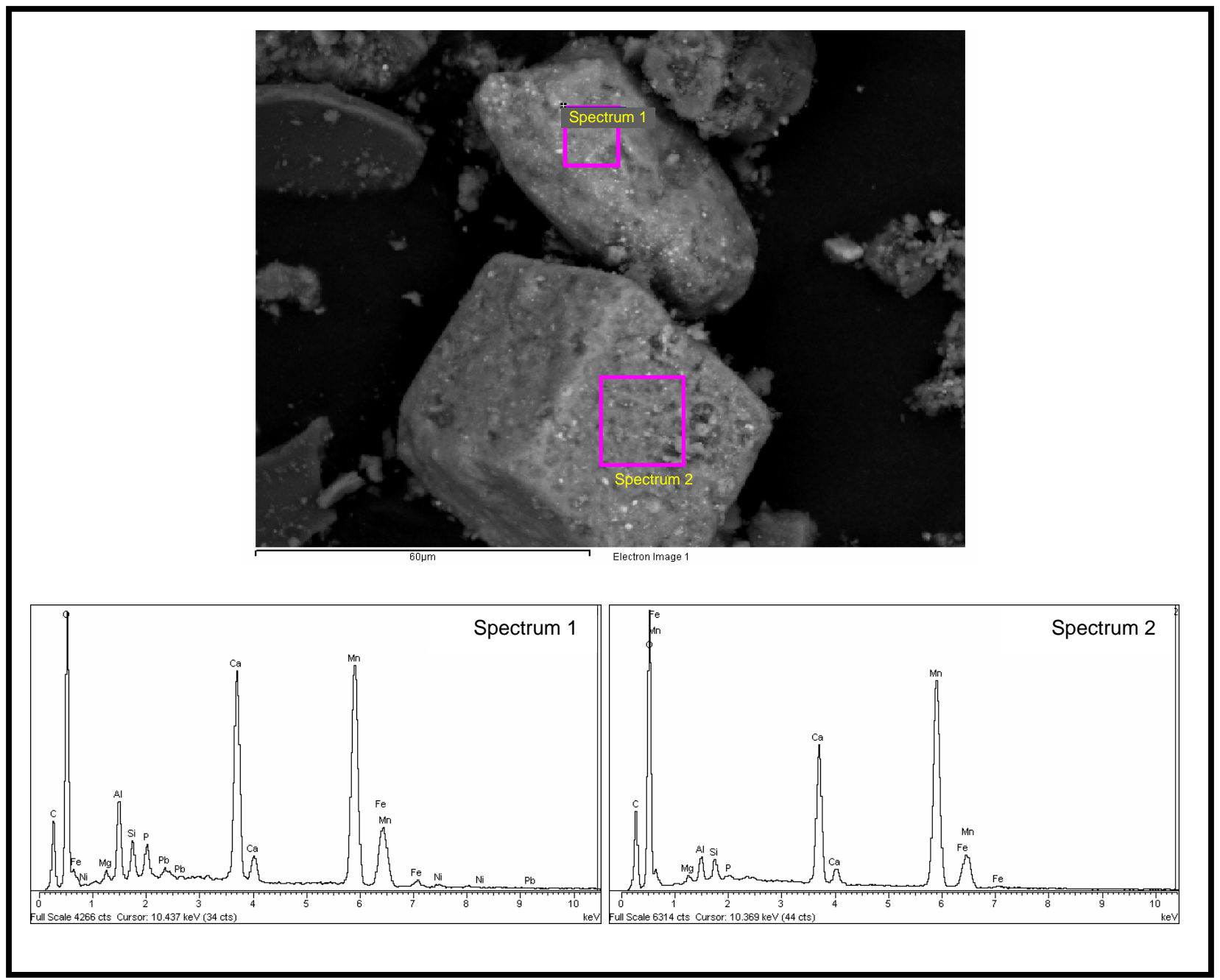

Figure C.19. EDS Spectra for Numbered Areas Marked in Pink in SEM Micrograph Shown at Top of Figure 


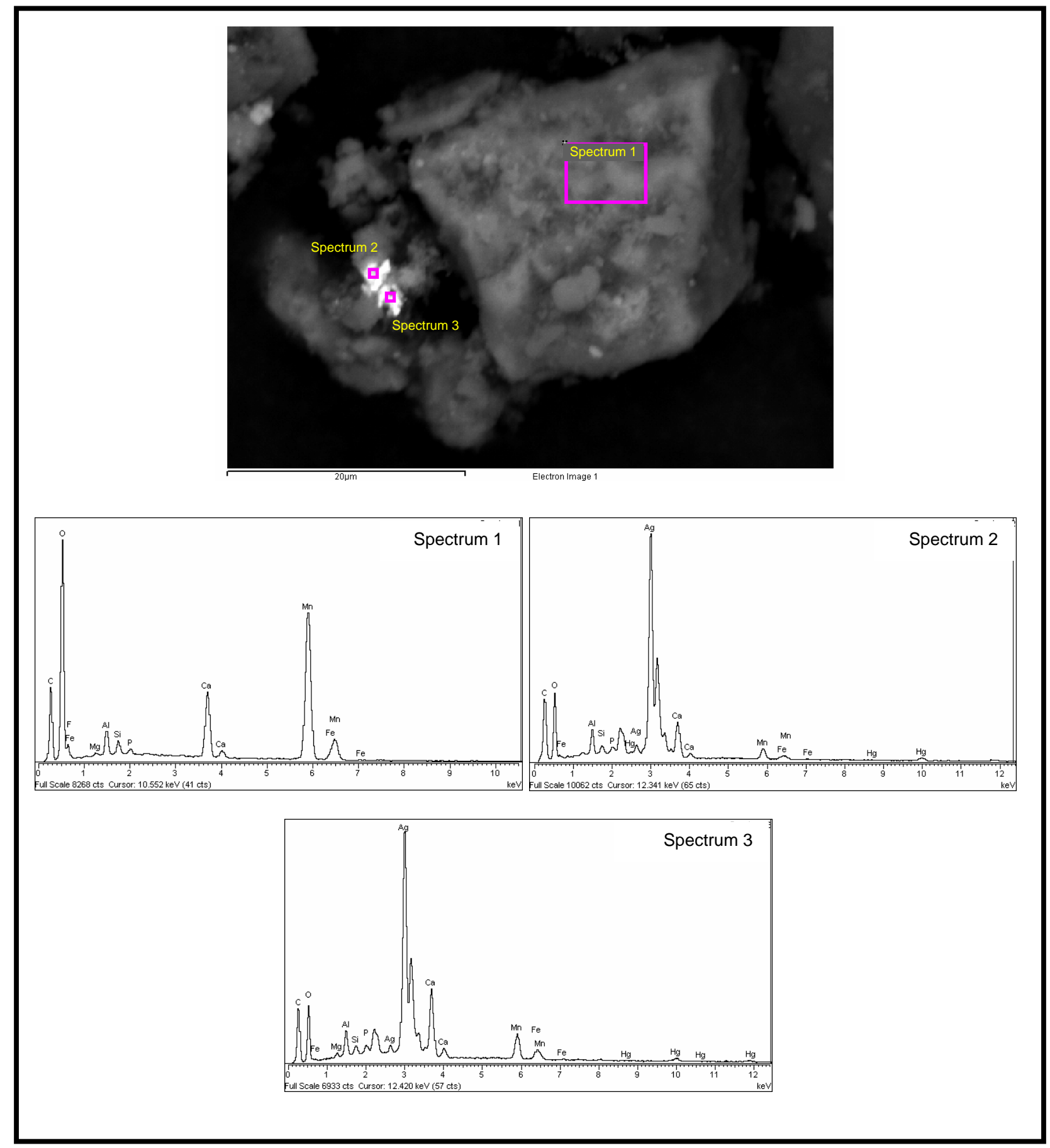

Figure C.20. EDS Spectra for Numbered Areas Marked in Pink in SEM Micrograph Shown at Top of Figure 


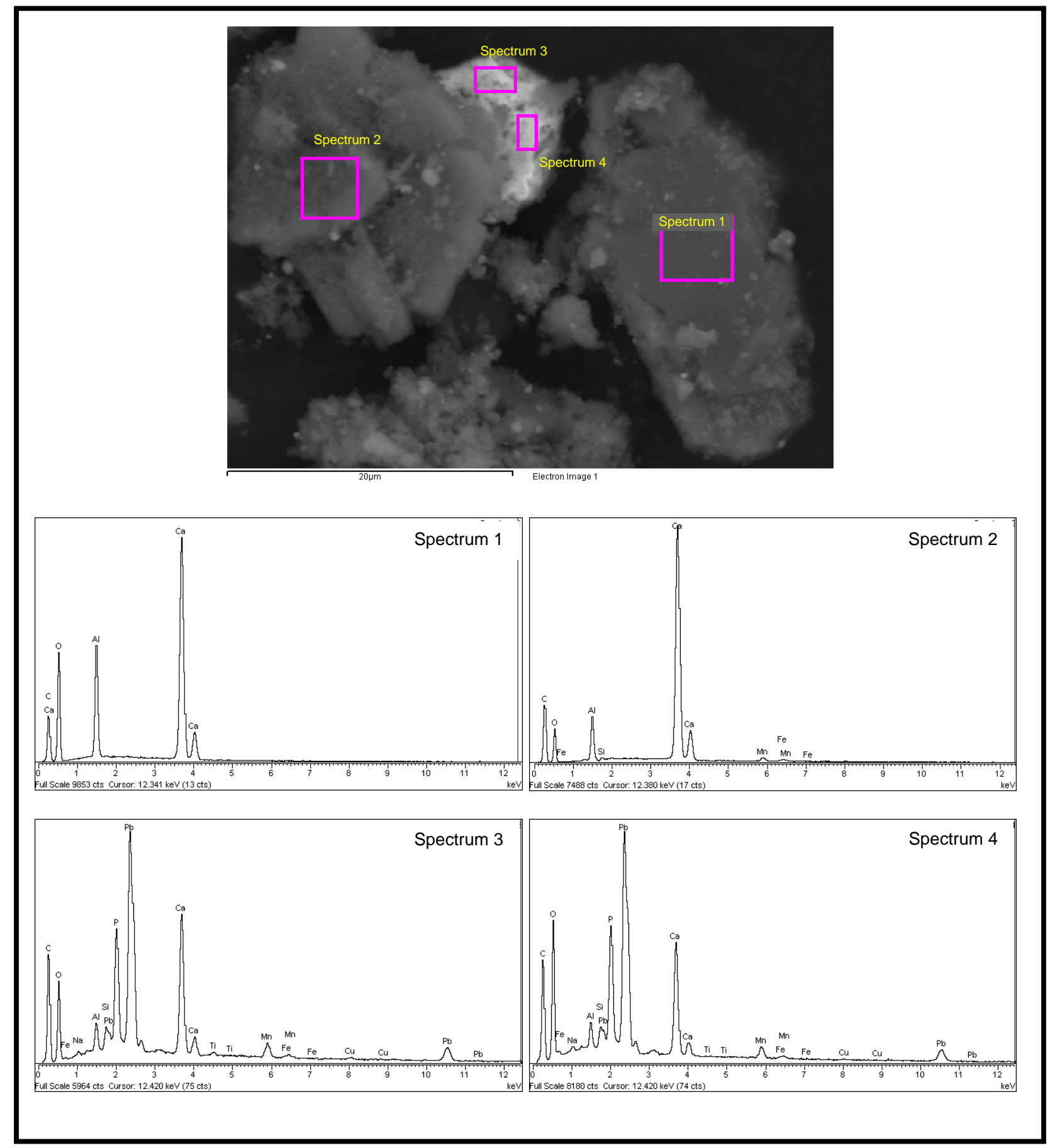

Figure C.21. EDS Spectra for Numbered Areas Marked in Pink in SEM Micrograph Shown at Top of Figure 


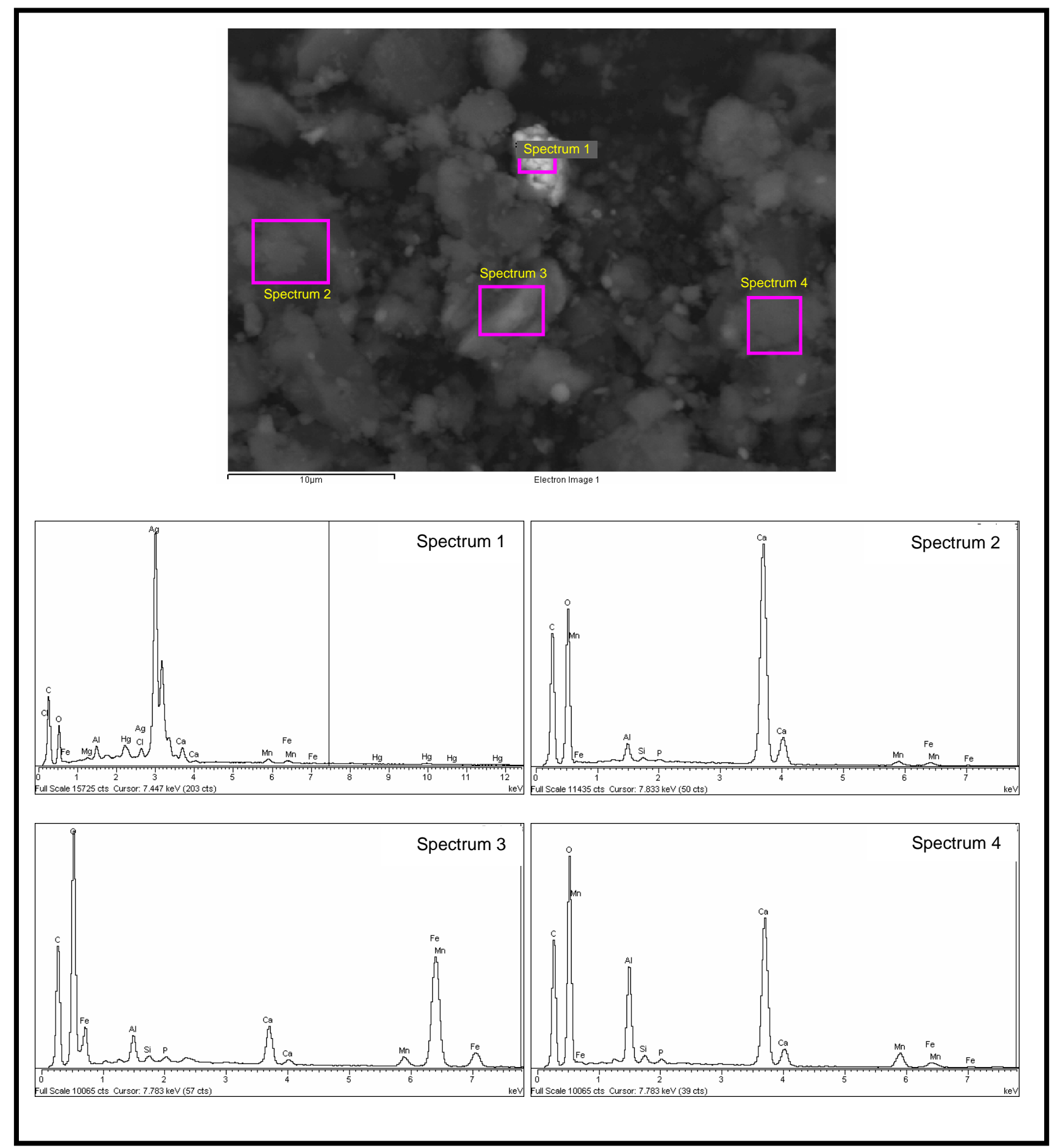

Figure C.22. EDS Spectra for Numbered Areas Marked in Pink in SEM Micrograph Shown at Top of Figure 


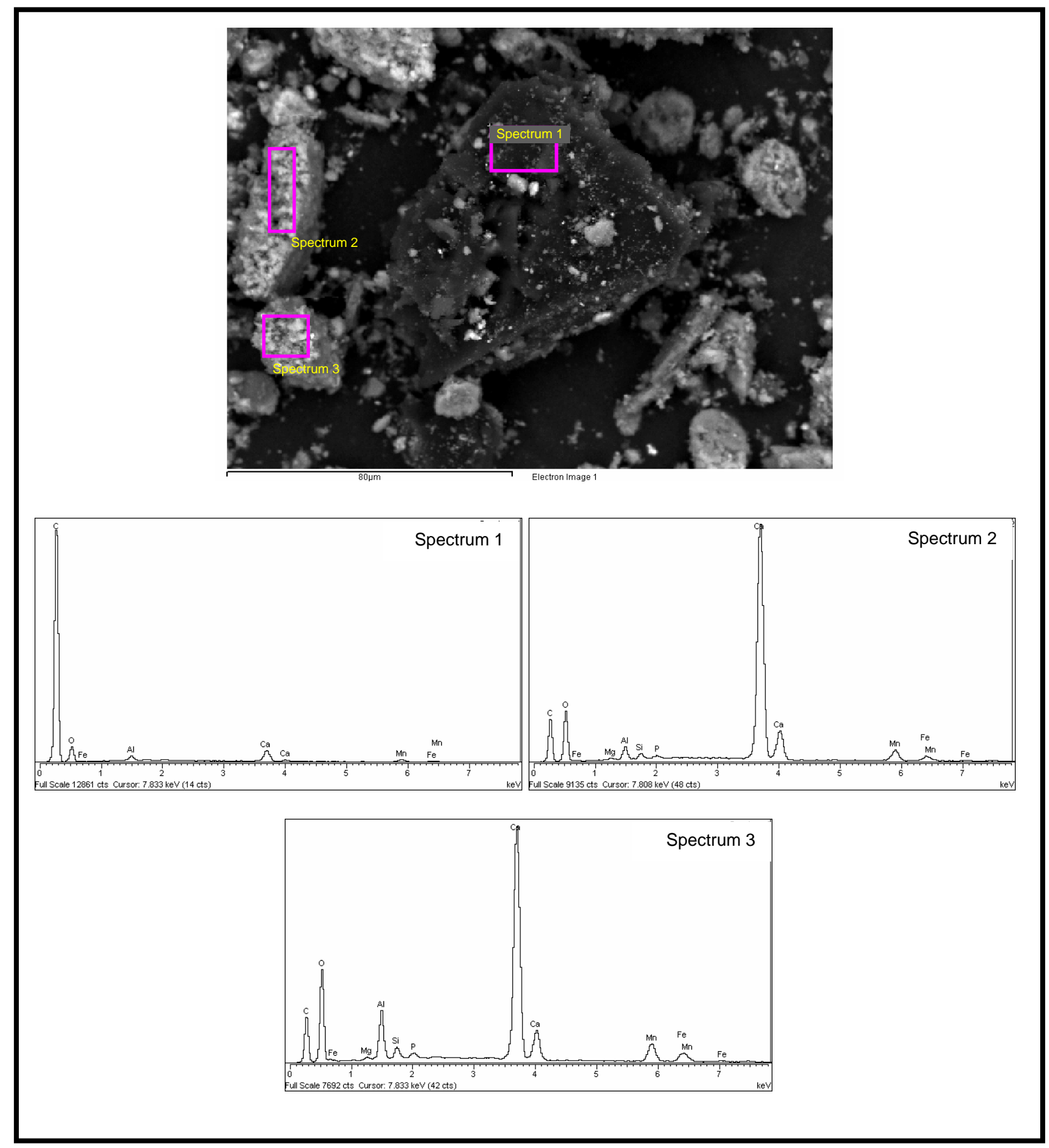

Figure C.23. EDS Spectra for Numbered Areas Marked in Pink in SEM Micrograph Shown at Top of Figure 


\section{Appendix D}

SEM Micrographs and EDS Results for

1-Month $\mathrm{Ca}(\mathrm{OH})_{2} / \mathrm{CaCO}_{3}$-Leached

Tank C-106 Residual Waste 


\section{Appendix D}

\section{SEM Micrographs and EDS Results for 1-Month $\mathrm{Ca}(\mathrm{OH})_{2} / \mathrm{CaCO}_{3}$-Leached Tank C-106 Residual Waste}

This appendix includes the scanning electron microscope (SEM) micrographs and the energydispersive x-ray spectrometry (EDS) spectra, and element-distribution maps for samples of 1-month $\mathrm{Ca}(\mathrm{OH})_{2} / \mathrm{CaCO}_{3}$-leached residual waste from tank C-106. The operating conditions for the SEM and procedures used for mounting the SEM samples are described in Section 3.4 of the main report.

The identification number for the digital micrograph image file, descriptor for the type of sample, and a size scale bar are given, respectively, at the bottom left, center, and right of each SEM micrograph in this appendix. Micrographs labeled by "BSE" to the immediate right of the digital image file number indicate that the micrograph was collected with backscattered electrons. Sample areas or particles identified by a letter, arrow, and/or outlined by a white or black dotted-line squares in a micrograph designate sample material that was imaged at higher magnification, which is typically shown in figure(s) that immediately follow in the series for that sample. The SEM micrographs for this leached material are shown in Figures D.1 through D.16. The EDS spectra for this mount are given in Figures D.17 through D.24. 

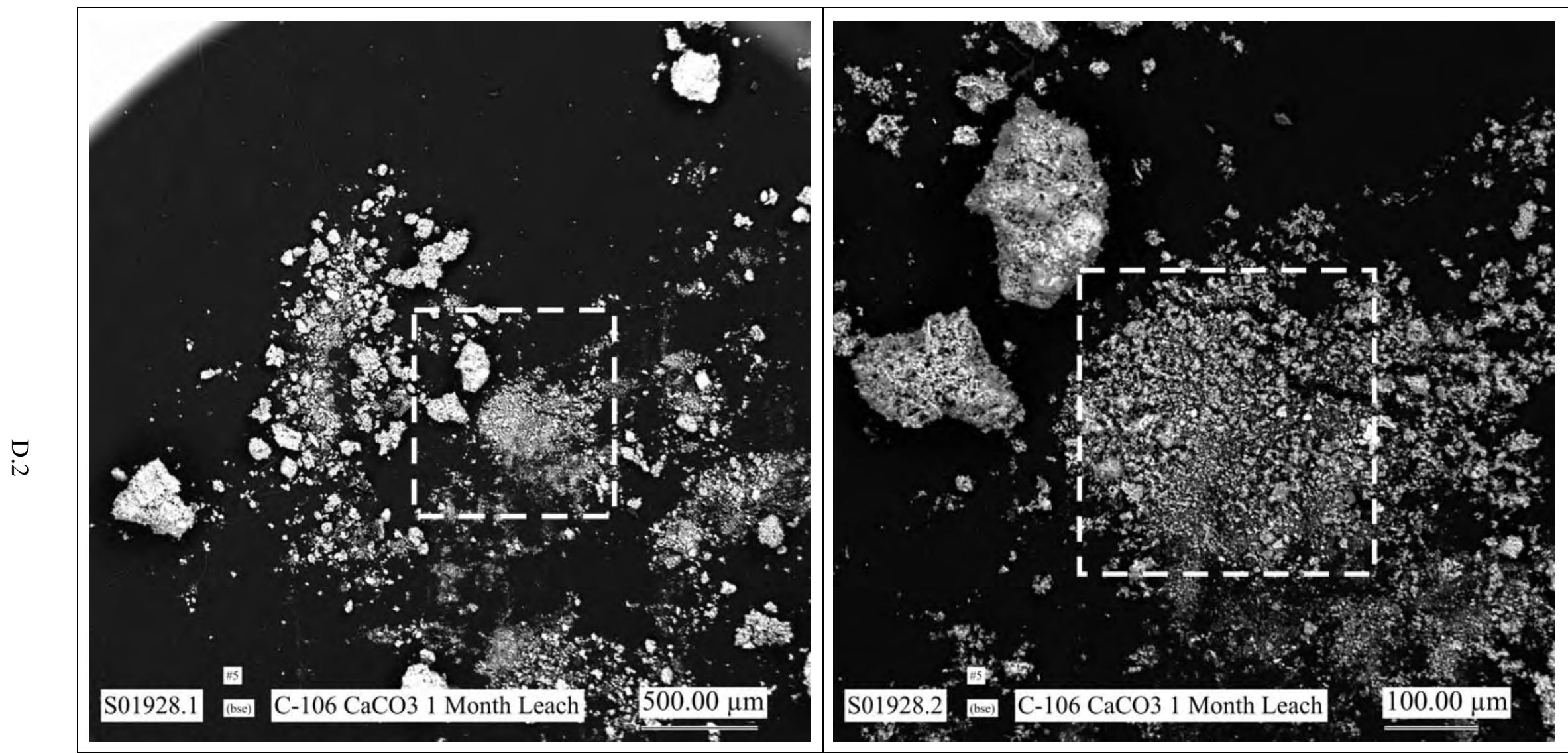

Figure D.1. Low Magnification SEM Micrograph Showing General Morphologies of Particles in SEM Sample of 1-Month $\mathrm{Ca}(\mathrm{OH})_{2} / \mathrm{CaCO}_{3}$-Leached Residual Waste from

Figure D.2. Micrograph Showing at Higher Magnification the Area Indicated by the White Dashed-Line Square in Figure D.1 Tank C-106 


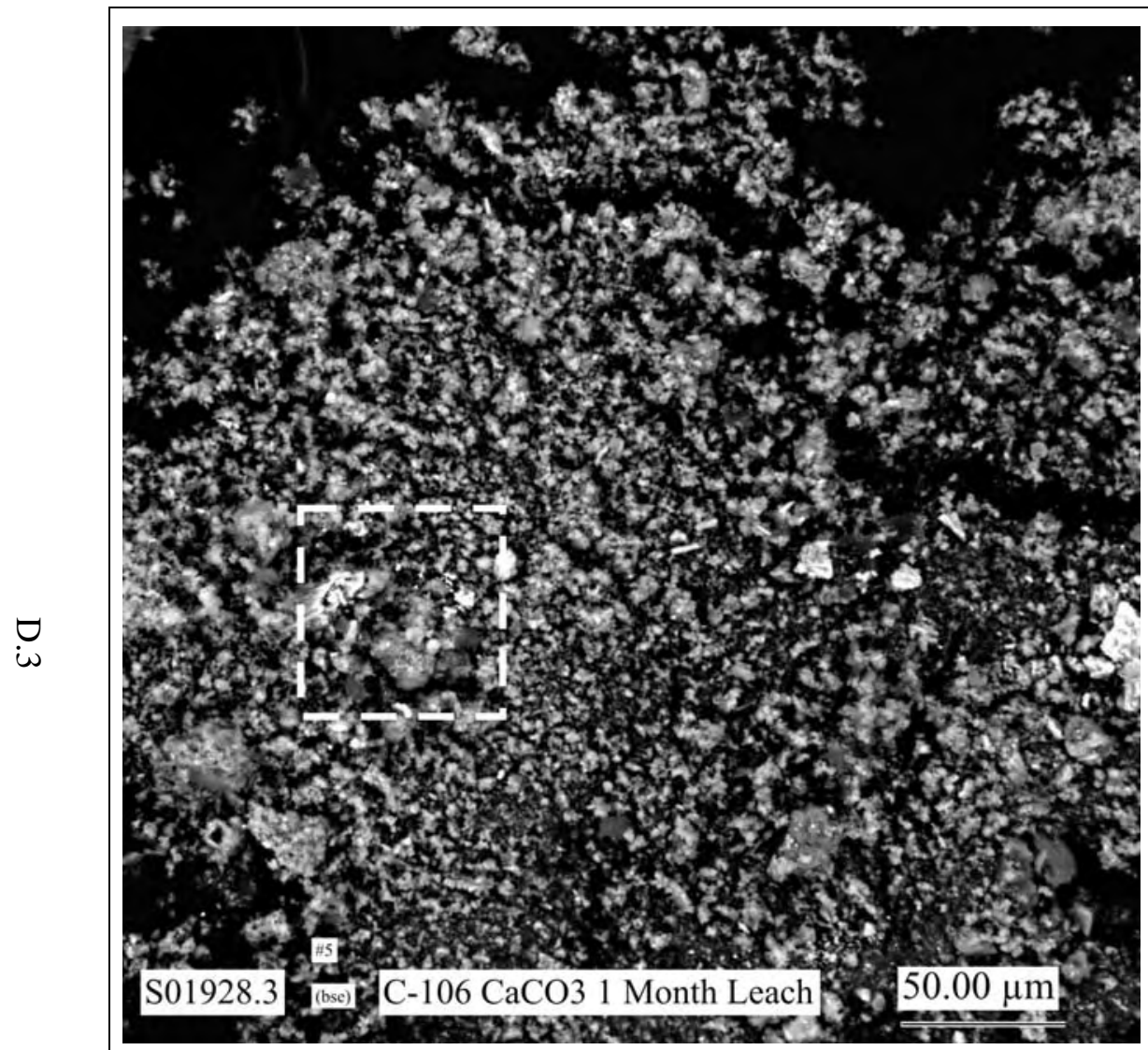

Figure D.3. Micrograph Showing at Higher Magnification the Area Indicated by the White Dashed-Line Square in Figure D.2

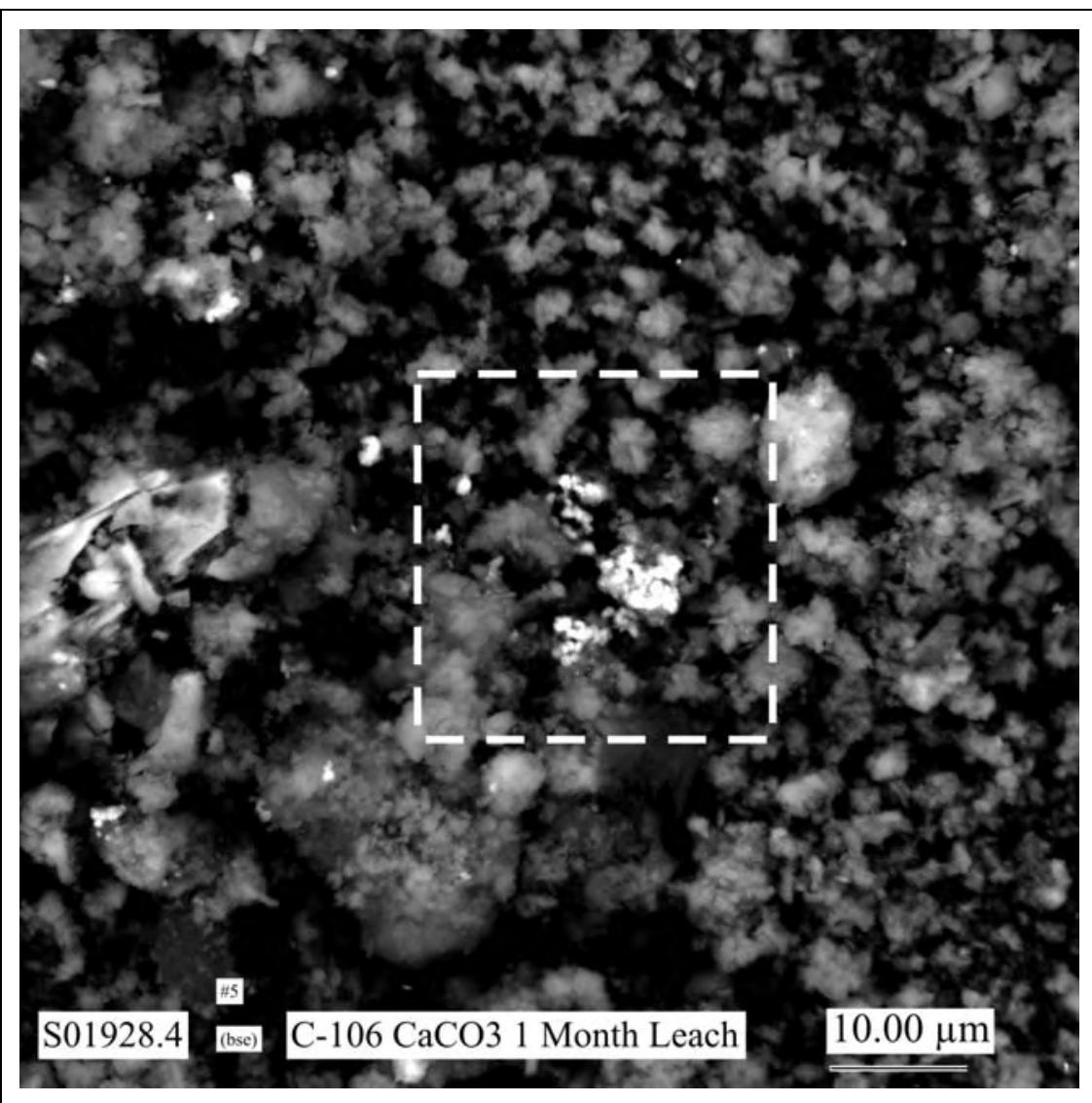

Figure D.4. Micrograph Showing at Higher Magnification the Area Indicated by the White Dashed-Line Square in Figure D.3 


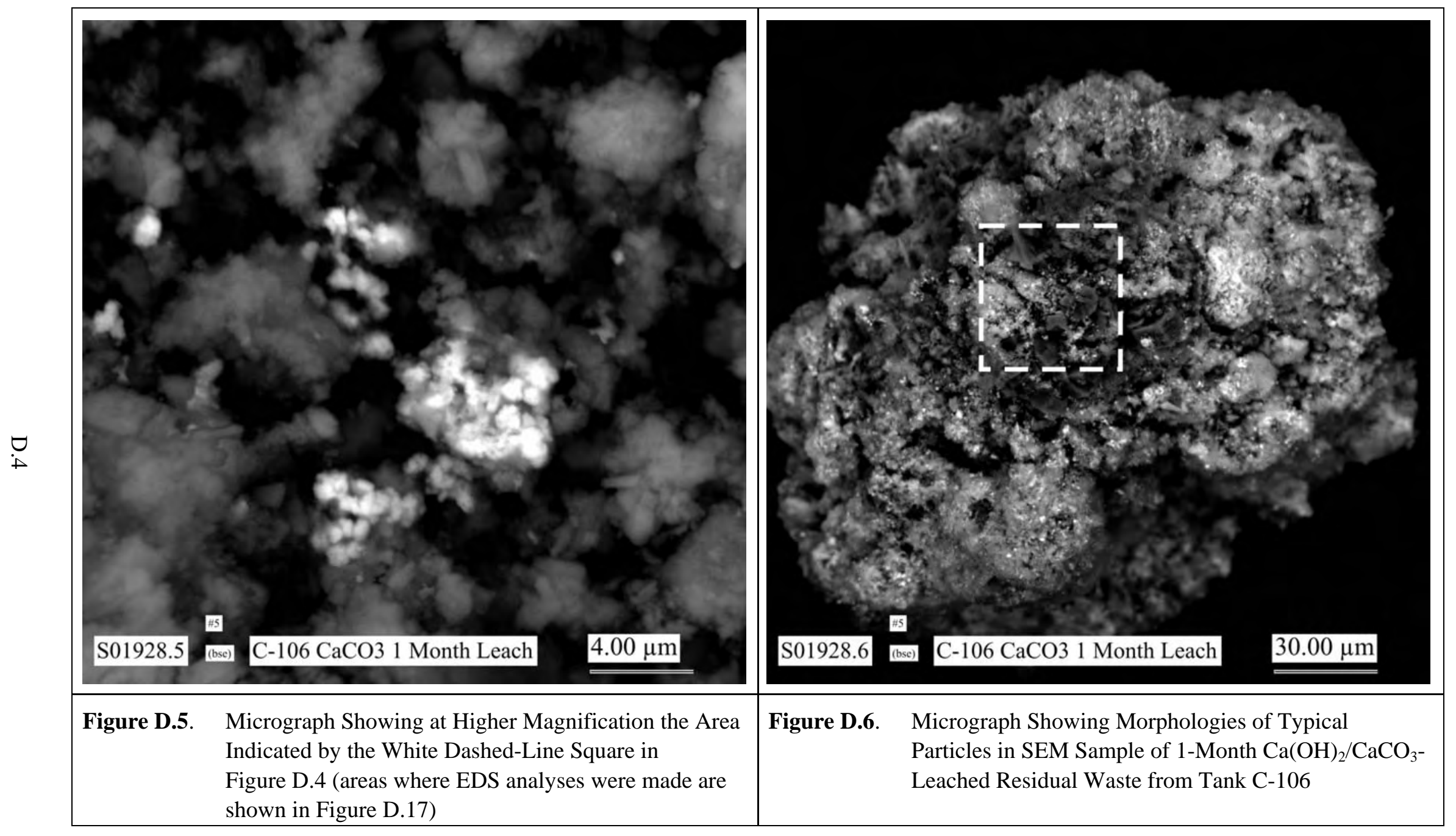




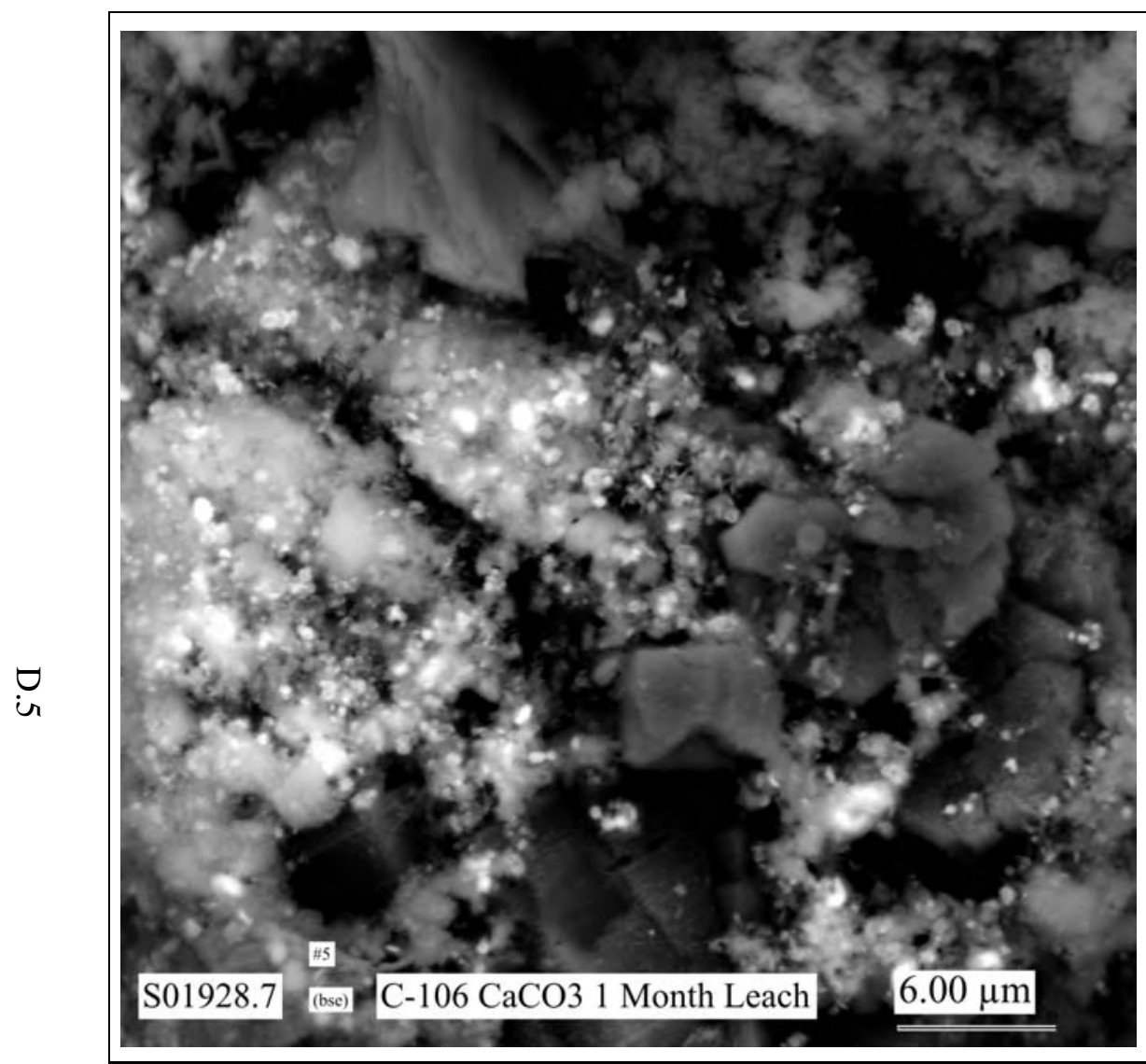

Figure D.7. Micrograph Showing at Higher Magnification the Area Indicated by the White Dashed-Line Square in Figure D.6 (areas where EDS analyses were made are shown in Figure D.18)

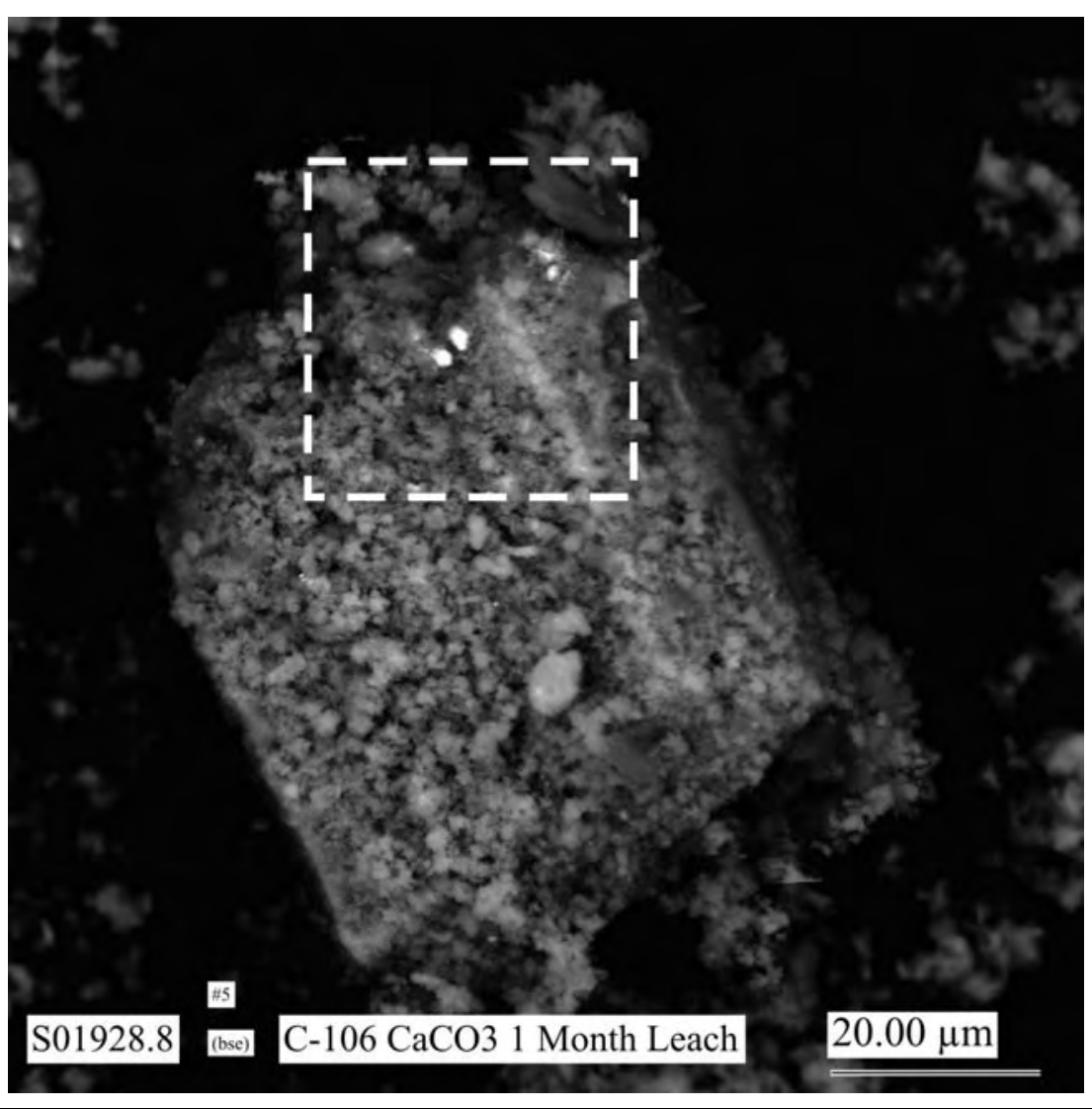

Figure D.8. Micrograph Showing Morphologies of Typical Particle Aggregates in SEM Sample of 1-Month $\mathrm{Ca}(\mathrm{OH})_{2} /$ $\mathrm{CaCO}_{3}$-Leached Residual Waste from Tank C-106 


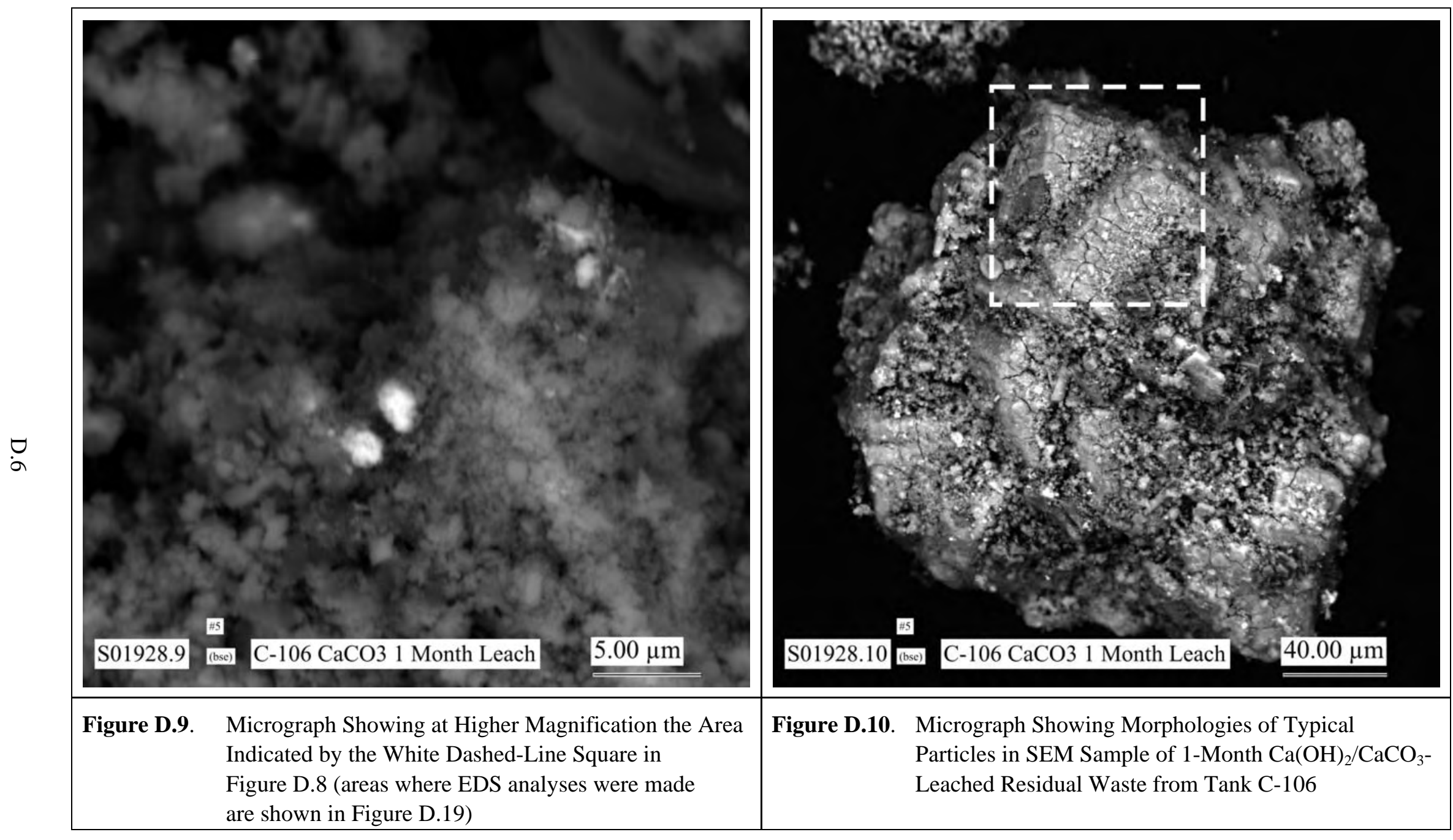




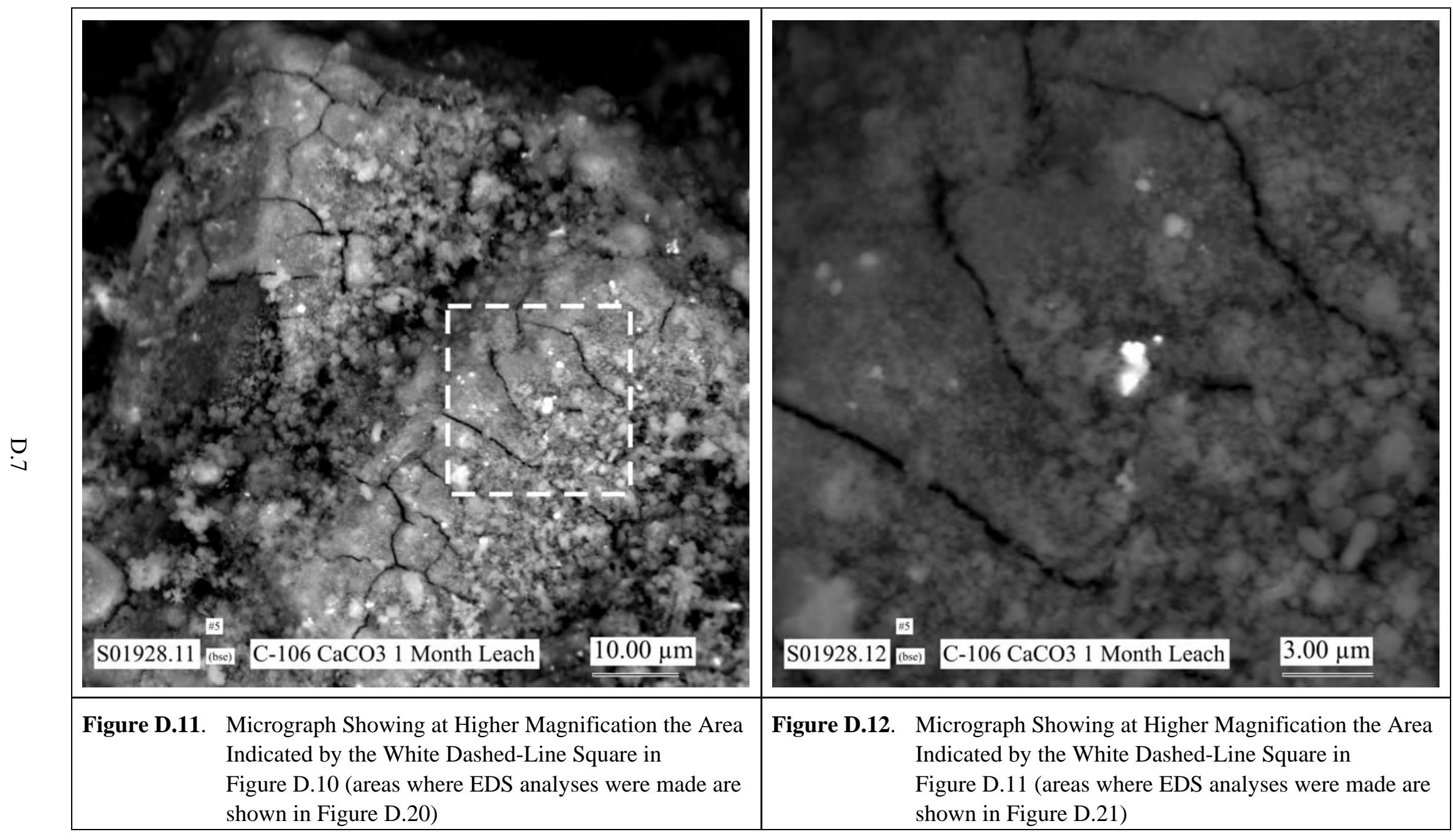




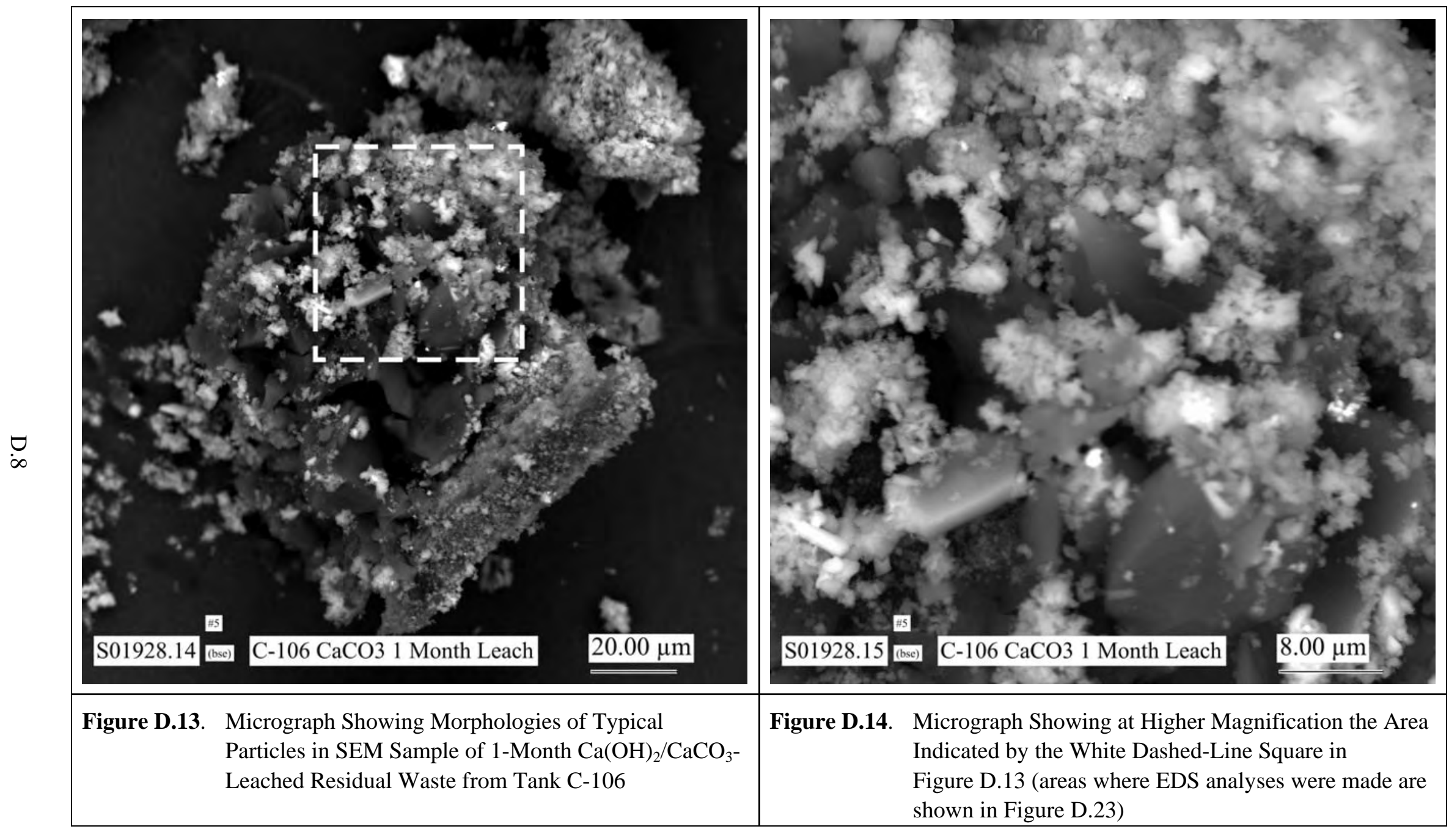




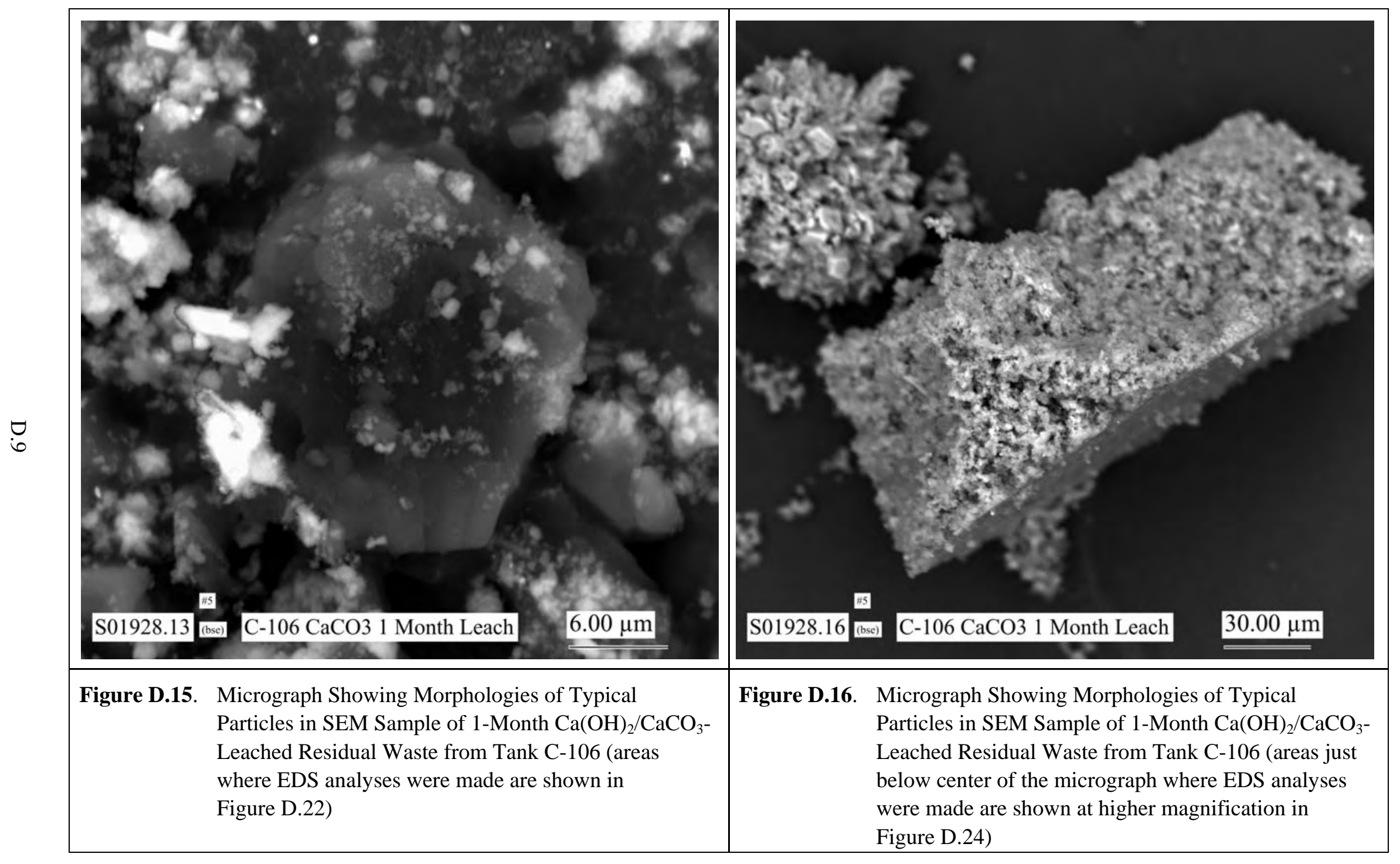




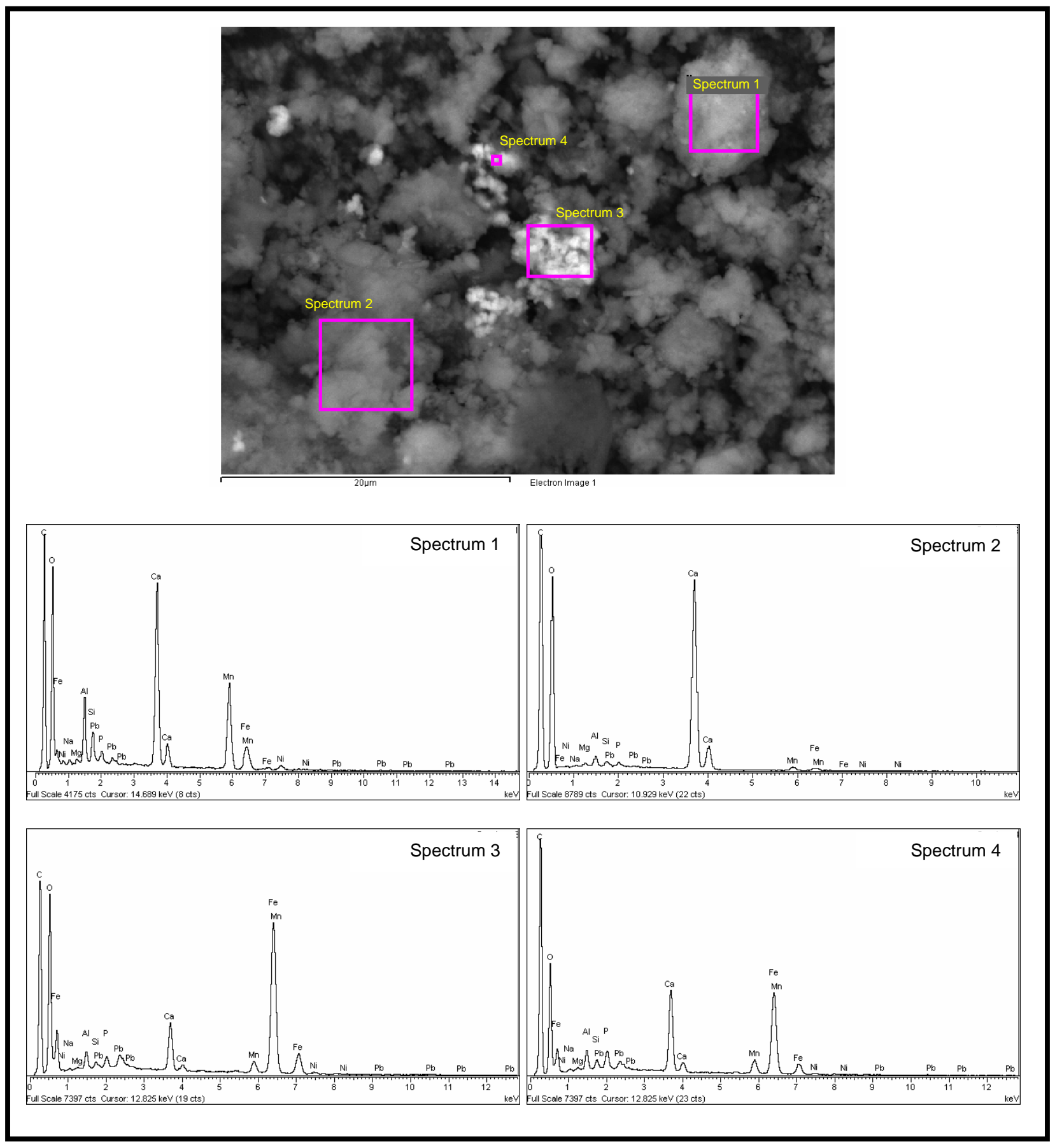

Figure D.17. EDS Spectra for Numbered Areas Marked in Pink in SEM Micrograph Shown at Top of Figure 


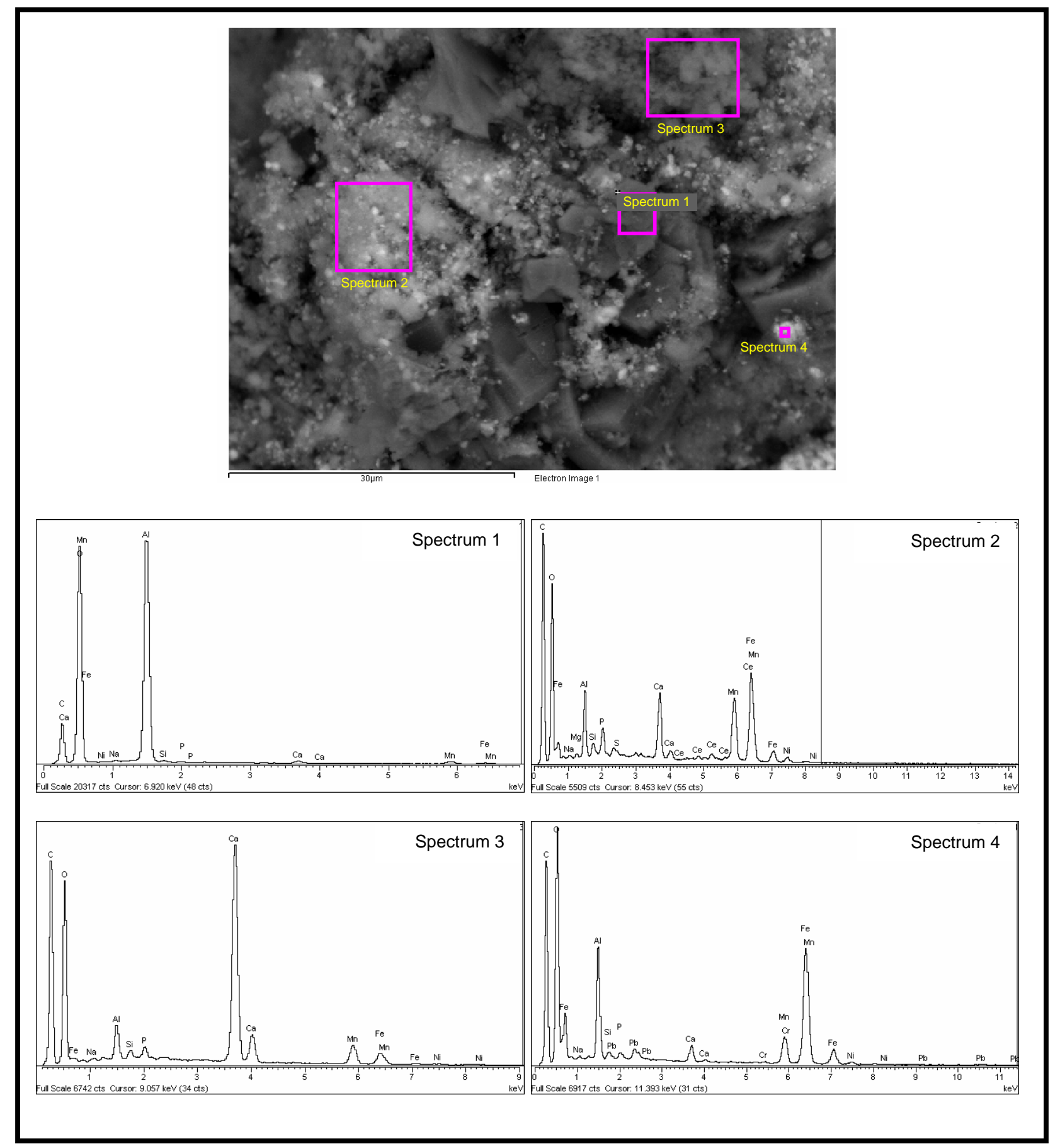

Figure D.18. EDS Spectra for Numbered Areas Marked in Pink in SEM Micrograph Shown at Top of Figure 


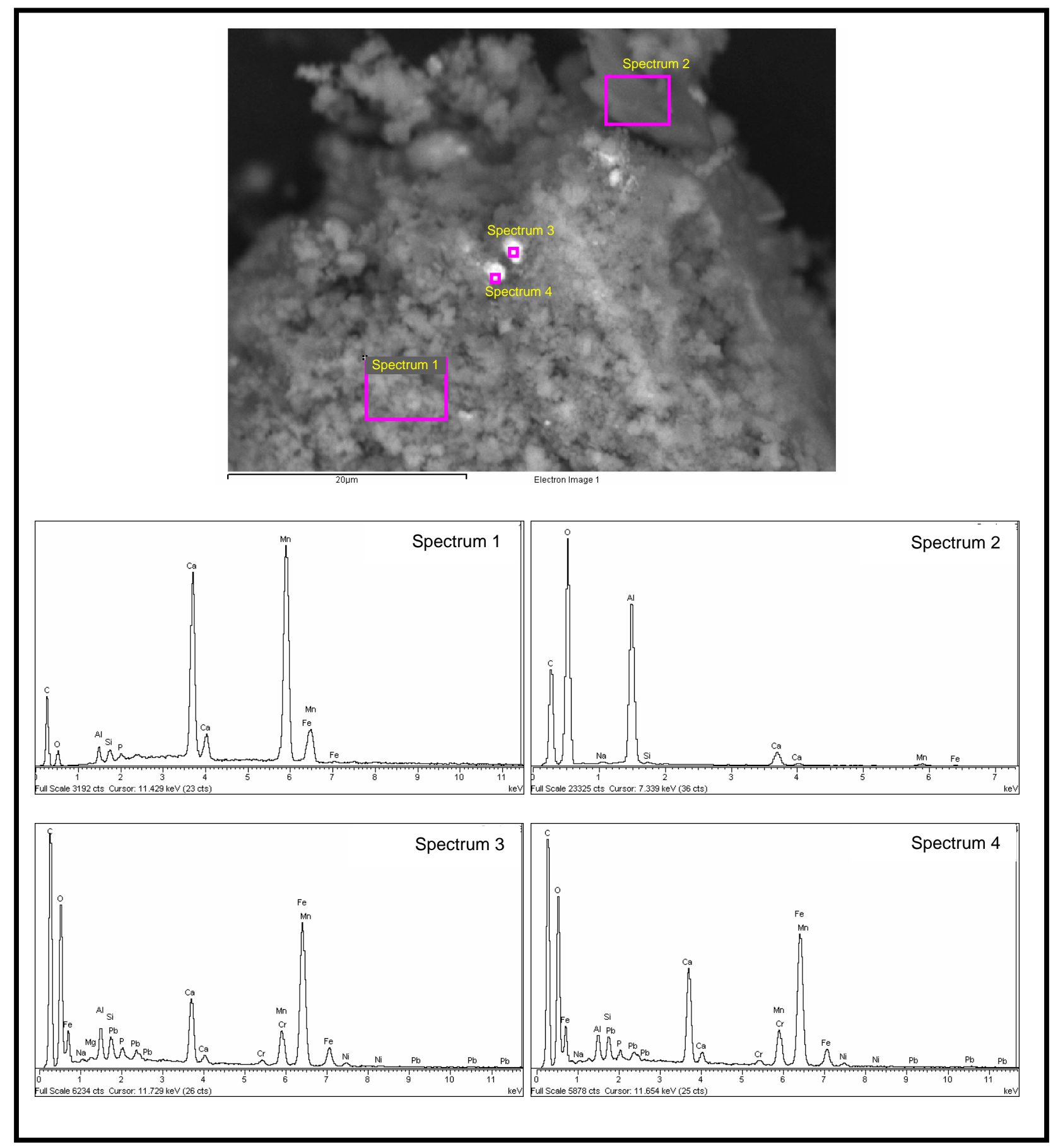

Figure D.19. EDS Spectra for Numbered Areas Marked in Pink in SEM Micrograph Shown at Top of Figure 


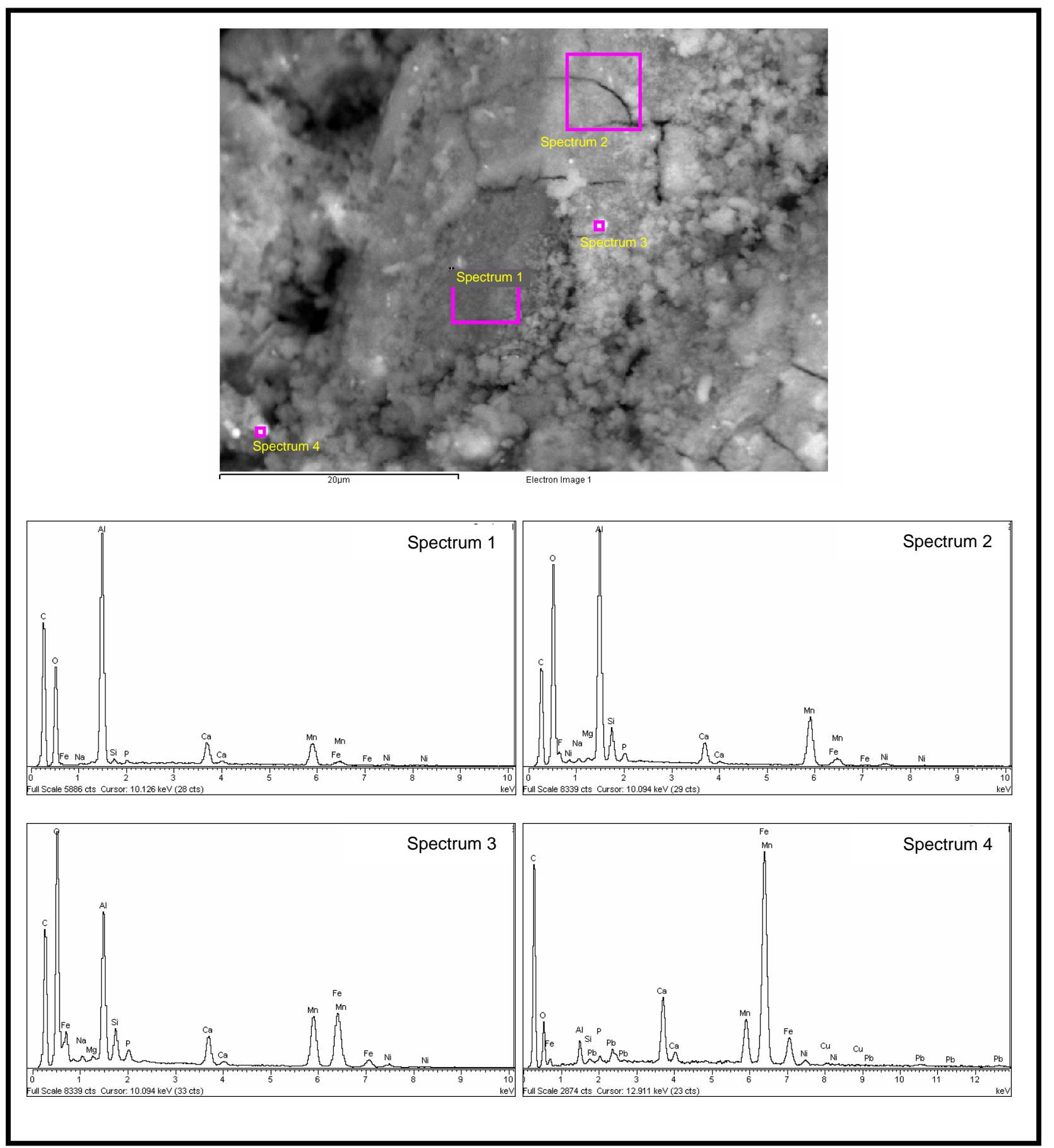

Figure D.20. EDS Spectra for Numbered Areas Marked in Pink in SEM Micrograph Shown at Top of Figure 


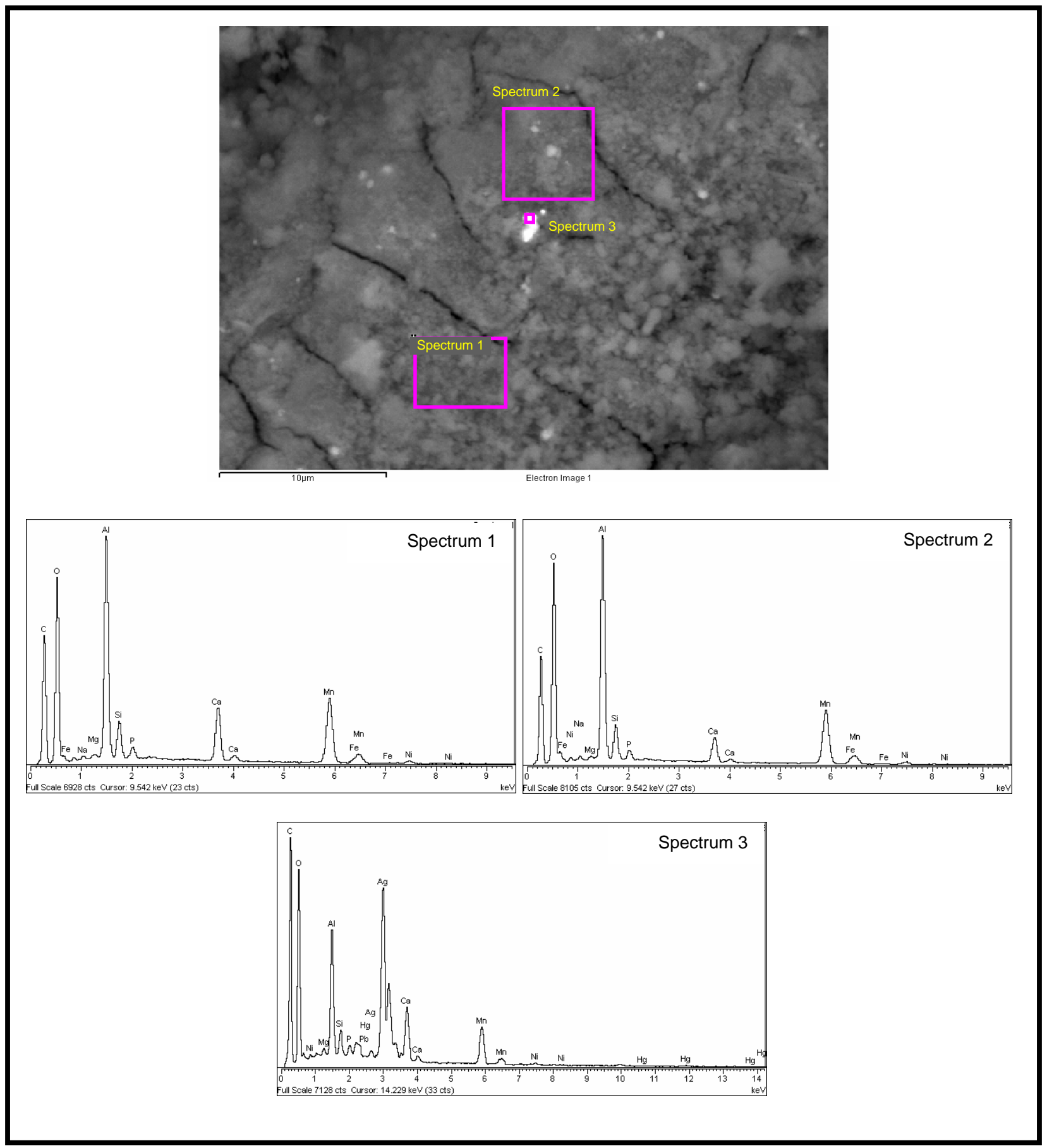

Figure D.21. EDS Spectra for Numbered Areas Marked in Pink in SEM Micrograph Shown at Top of Figure 


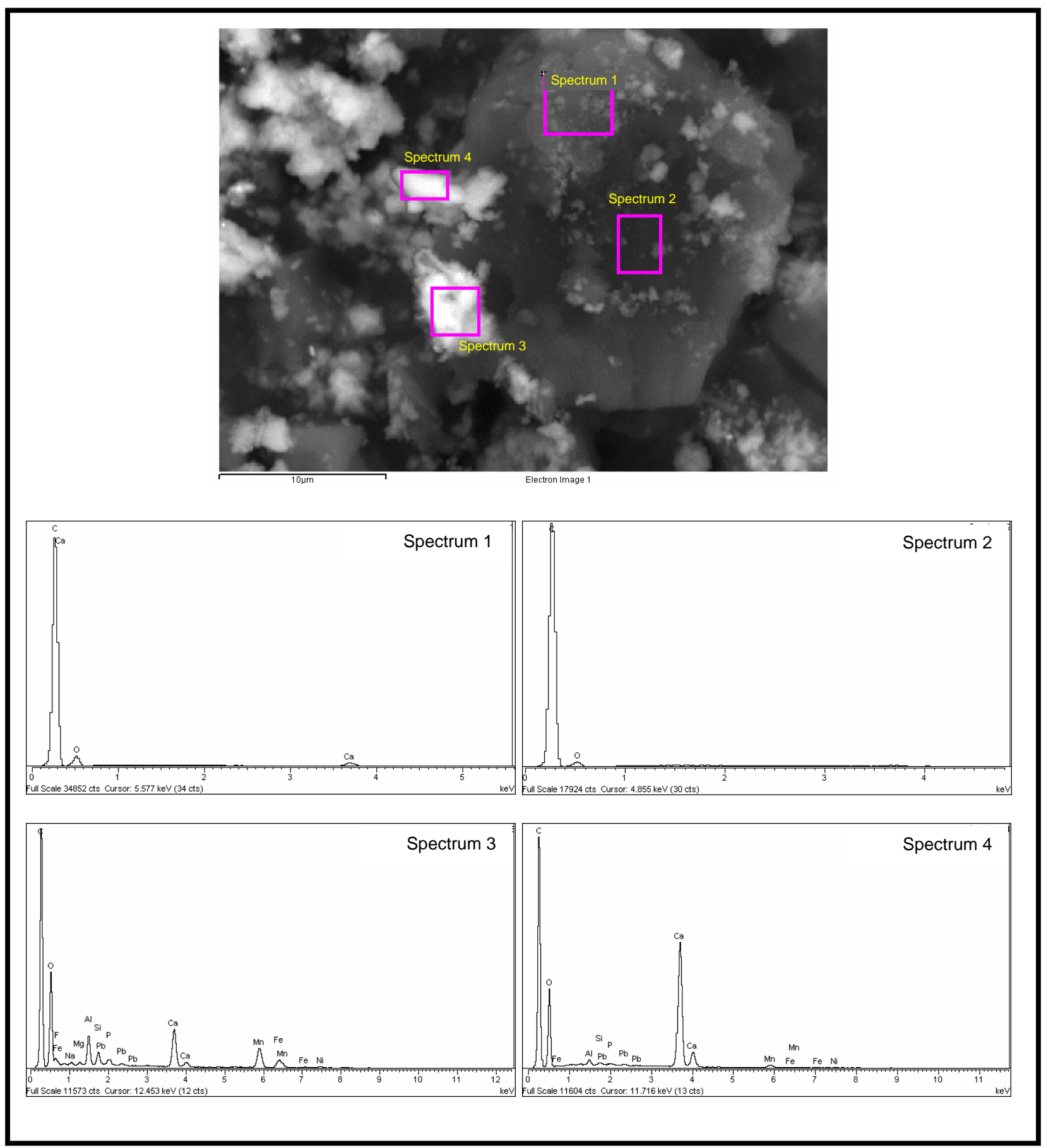

Figure D.22. EDS Spectra for Numbered Areas Marked in Pink in SEM Micrograph Shown at Top of Figure

D.15 


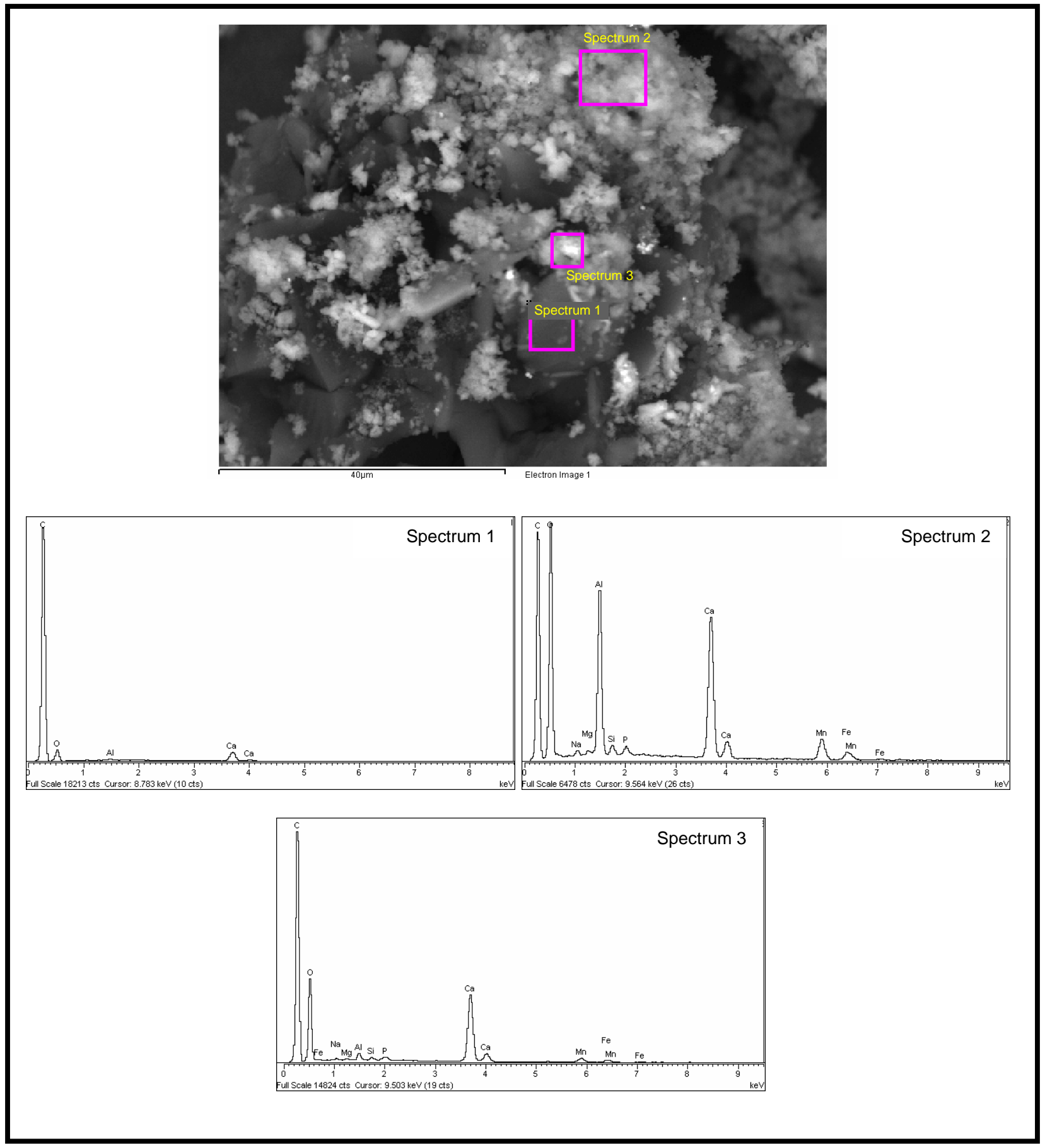

Figure D.23. EDS Spectra for Numbered Areas Marked in Pink in SEM Micrograph Shown at Top of Figure 


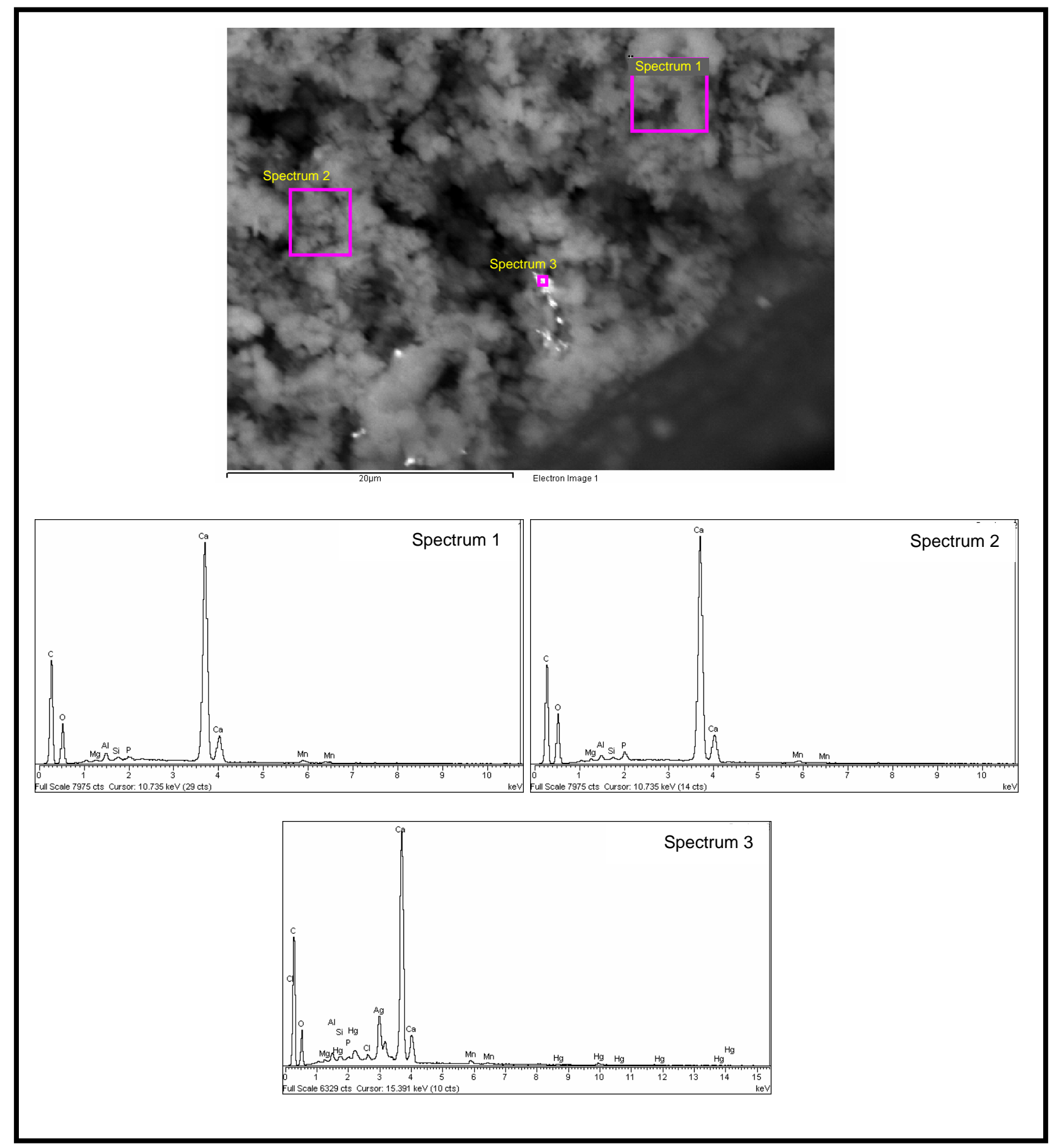

Figure D.24. EDS Spectra for Numbered Areas Marked in Pink in SEM Micrograph Shown at Top of Figure 


\section{Appendix E}

SEM Micrographs and EDS Results for

Stage 6 Sequential $\mathrm{Ca}(\mathrm{OH})_{2} / \mathrm{CaCO}_{3}$-Leached

Tank C-106 Residual Waste 


\section{Appendix E}

\section{SEM Micrographs and EDS Results for Stage 6 Sequential $\mathrm{Ca}(\mathrm{OH})_{2} / \mathrm{CaCO}_{3}$-Leached Tank C-106 Residual Waste}

This appendix includes the scanning electron microscope (SEM) micrographs and the energydispersive x-ray spectrometry (EDS) spectra, and element-distribution maps for samples of Stage 6 sequential $\mathrm{Ca}(\mathrm{OH})_{2} / \mathrm{CaCO}_{3}$-leached residual waste from tank $\mathrm{C}-106$. The operating conditions for the SEM and procedures used for mounting the SEM samples are described in Section 3.4 of the main report.

The identification number for the digital micrograph image file, descriptor for the type of sample, and a size scale bar are given, respectively, at the bottom left, center, and right of each SEM micrograph in this appendix. Micrographs labeled by "BSE" to the immediate right of the digital image file number indicate that the micrograph was collected with backscattered electrons. Sample areas or particles identified by a letter, arrow, and/or outlined by a white or black dotted-line squares in a micrograph designate sample material that was imaged at higher magnification, which is typically shown in figure(s) that immediately follow in the series for that sample. The SEM micrographs for this leached material are shown in Figures E.1 through E.12. The EDS spectra for this mount are given in Figures E.13 through E.21. 


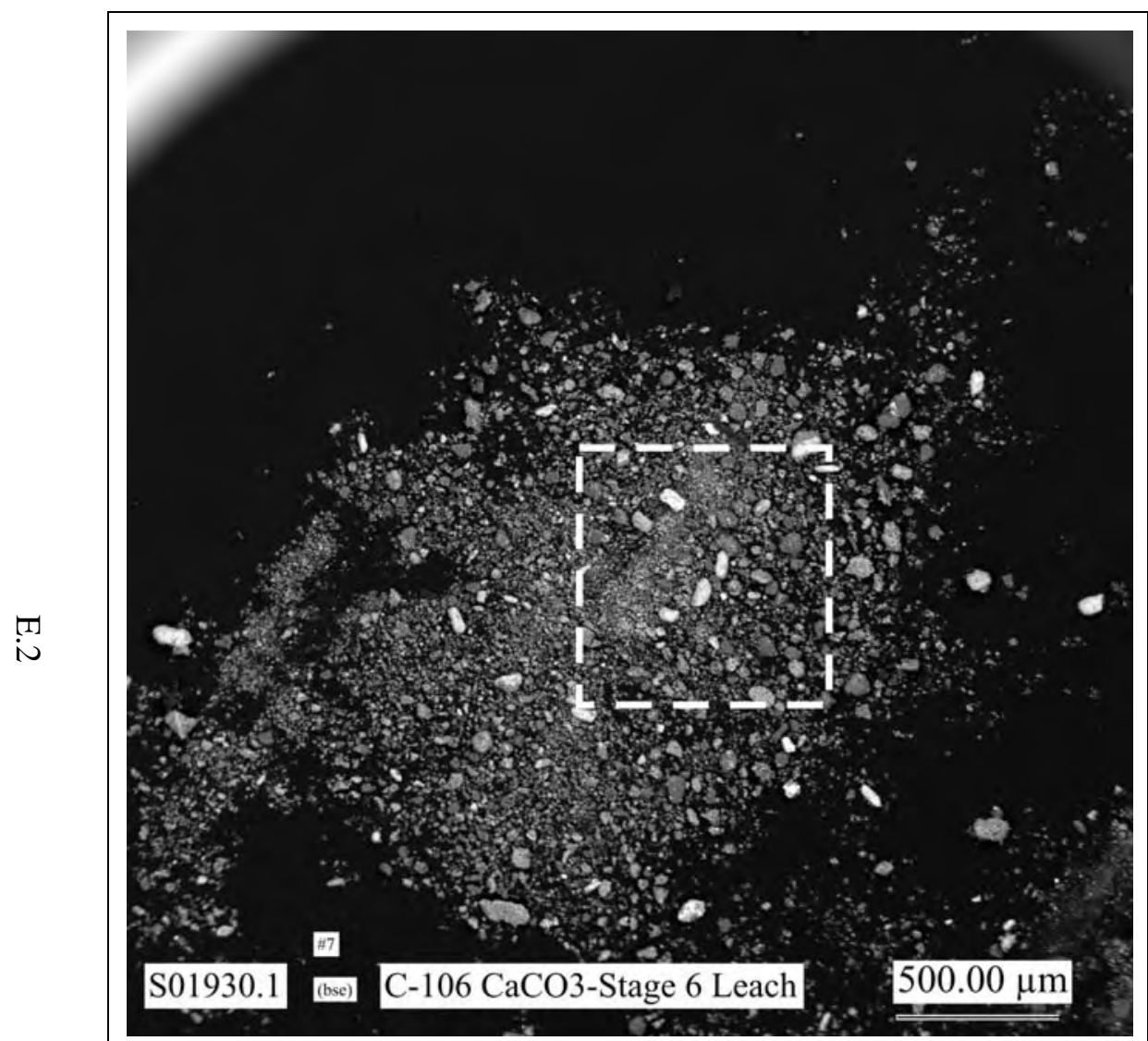

Figure E.1. Low Magnification SEM Micrograph Showing General Morphologies of Particles in the SEM Sample of Stage 6 Sequential $\mathrm{Ca}(\mathrm{OH})_{2} / \mathrm{CaCO}_{3}$-Leached Residual Waste from Tank C-106

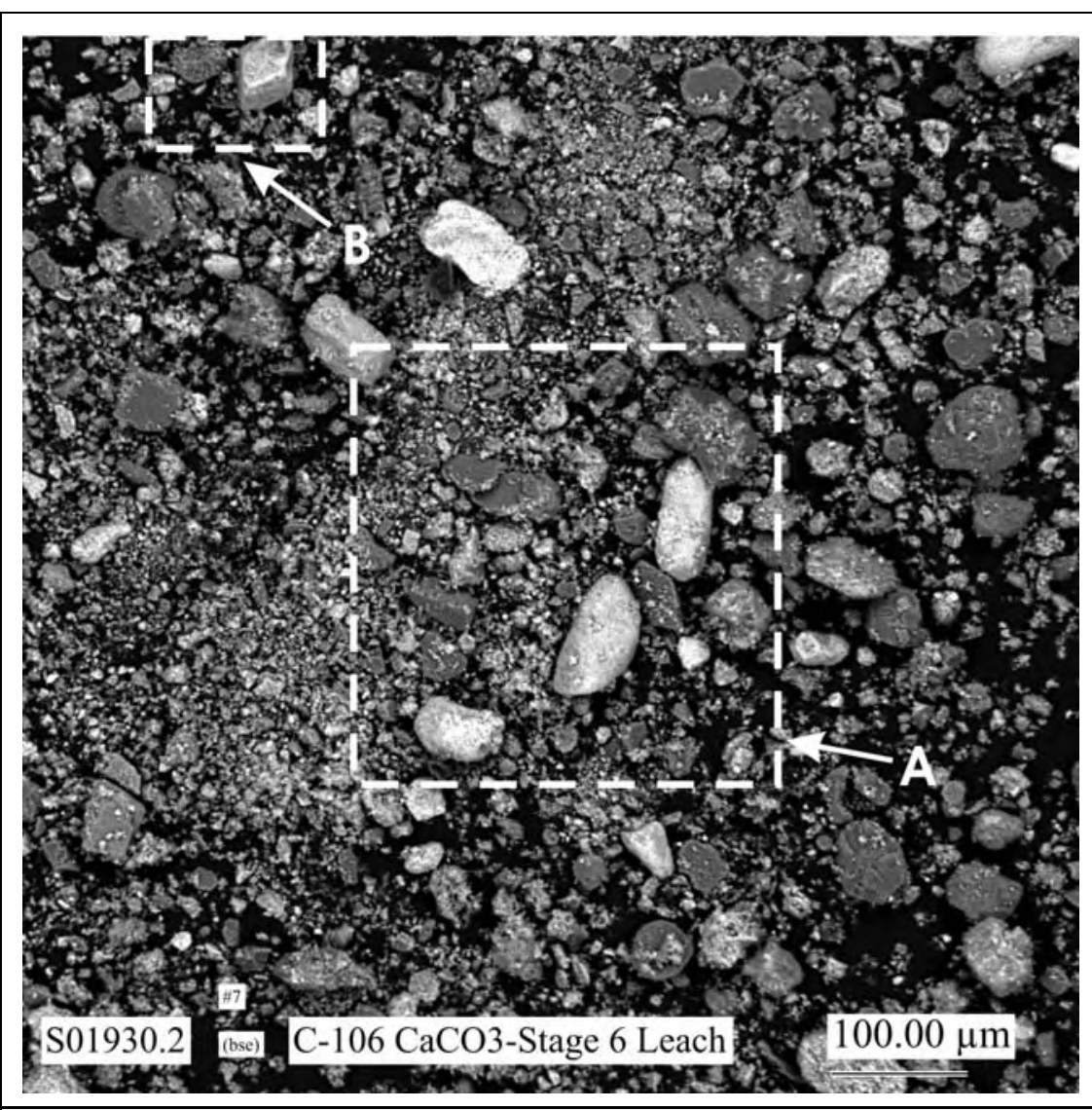

Figure E.2. Micrograph Showing at Higher Magnification the Area Indicated by the White Dashed-Line Square in Figure E.1 


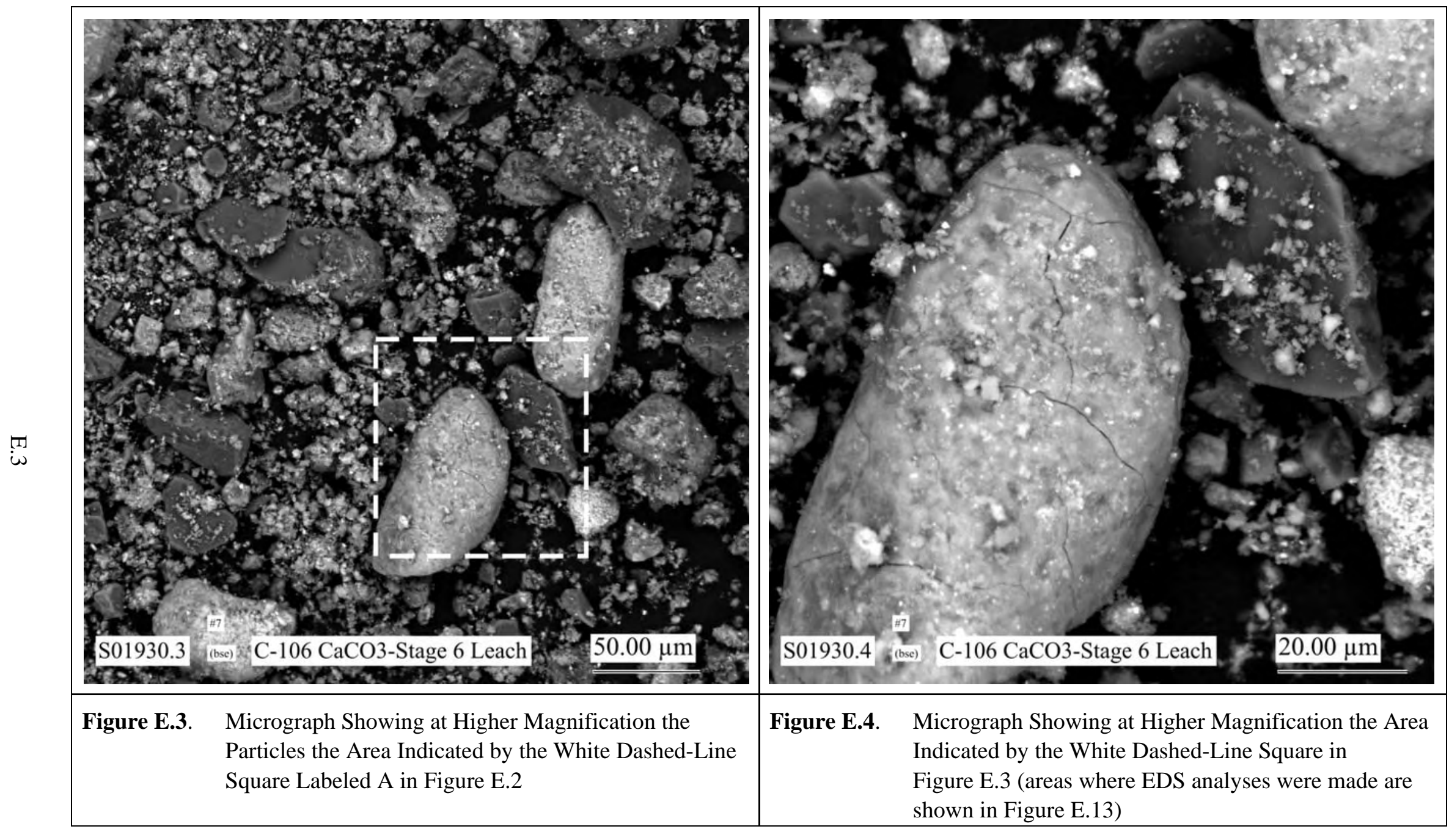




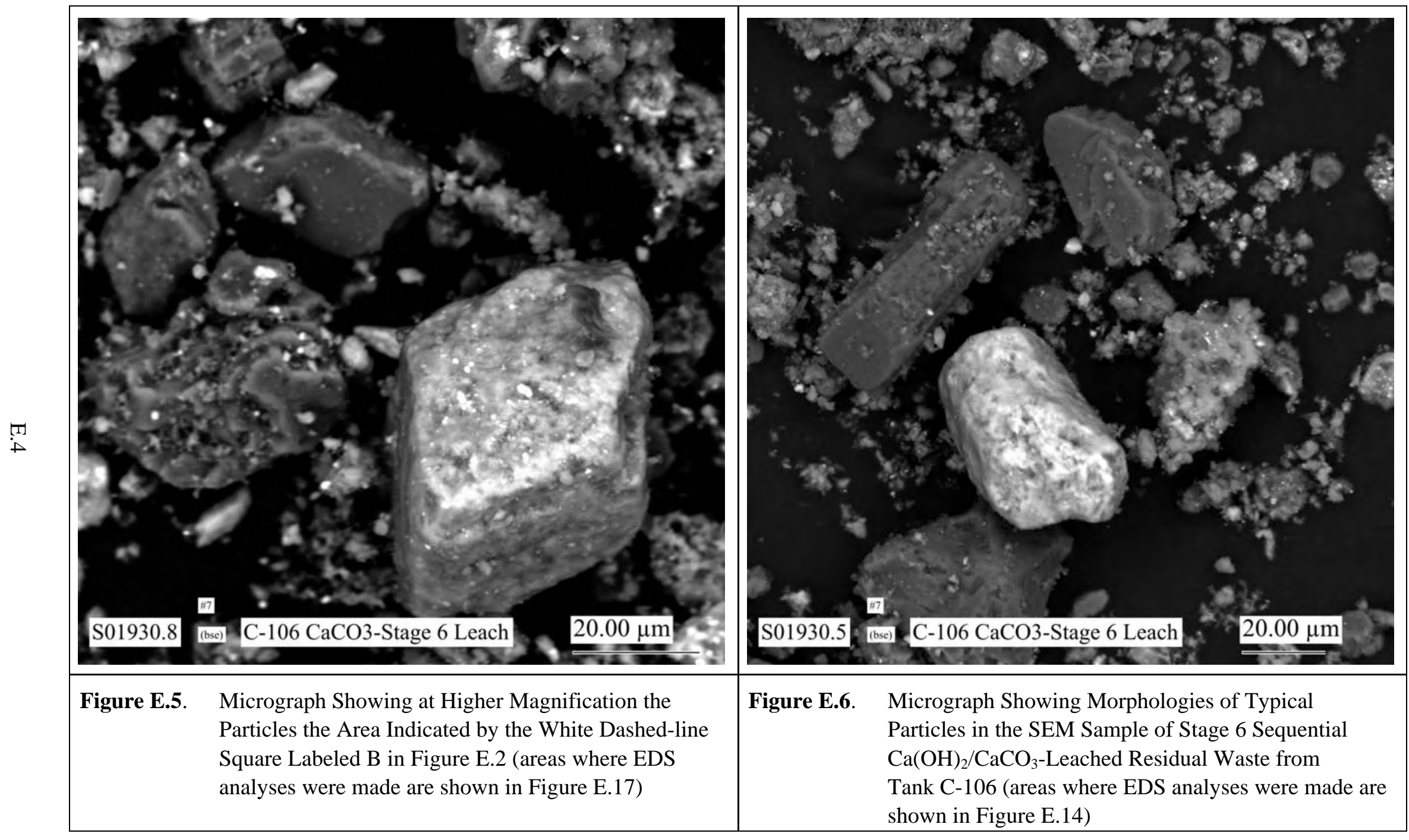




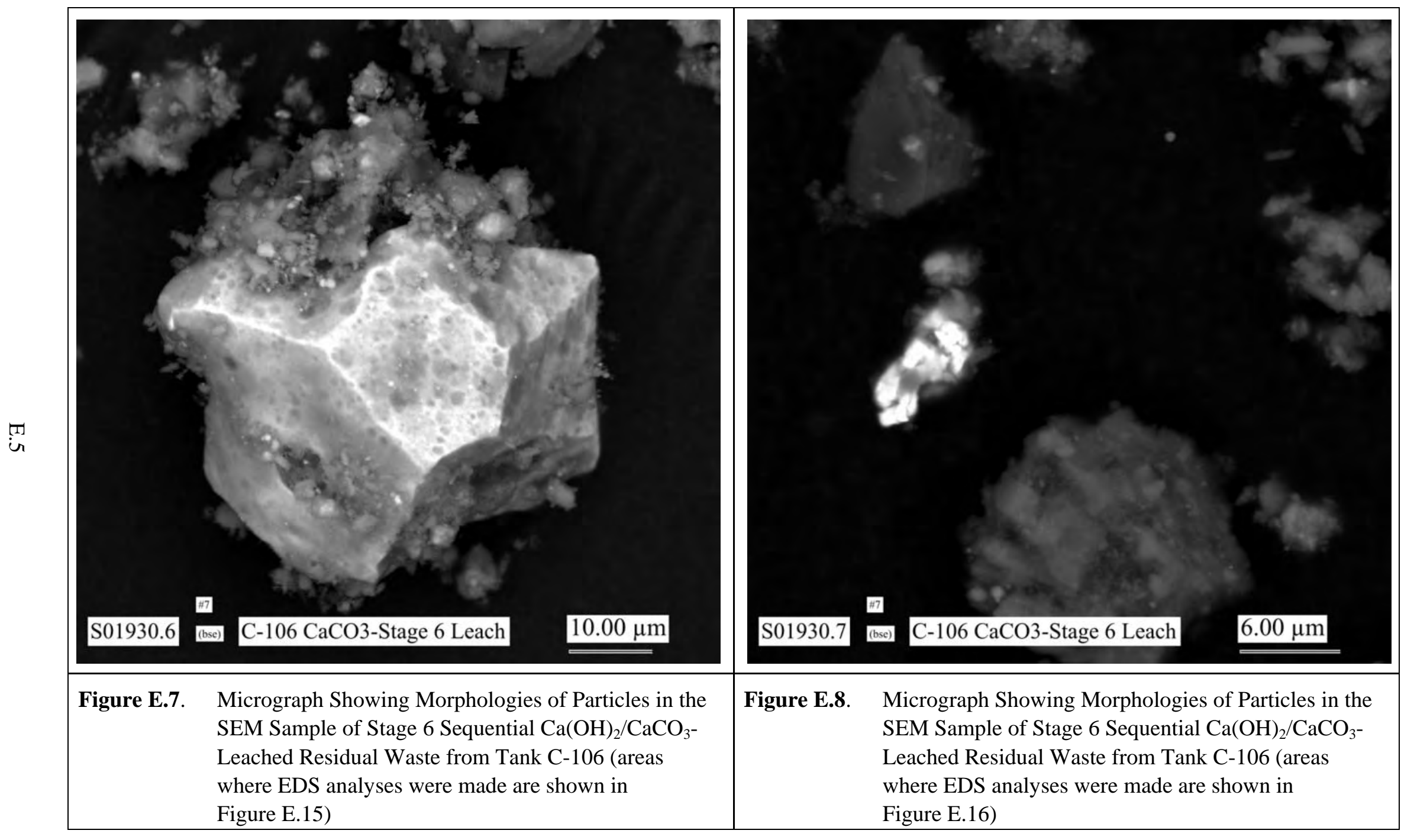




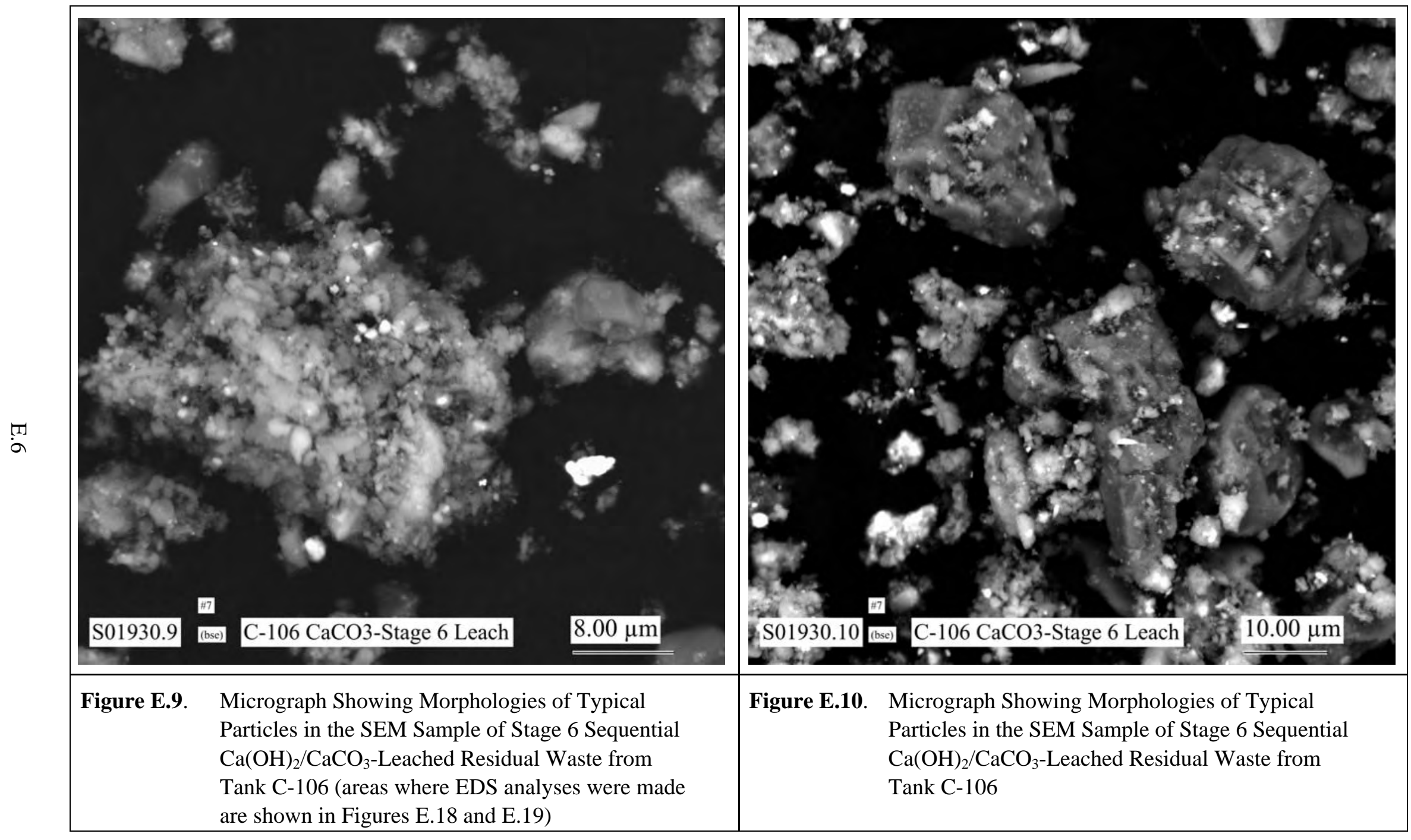




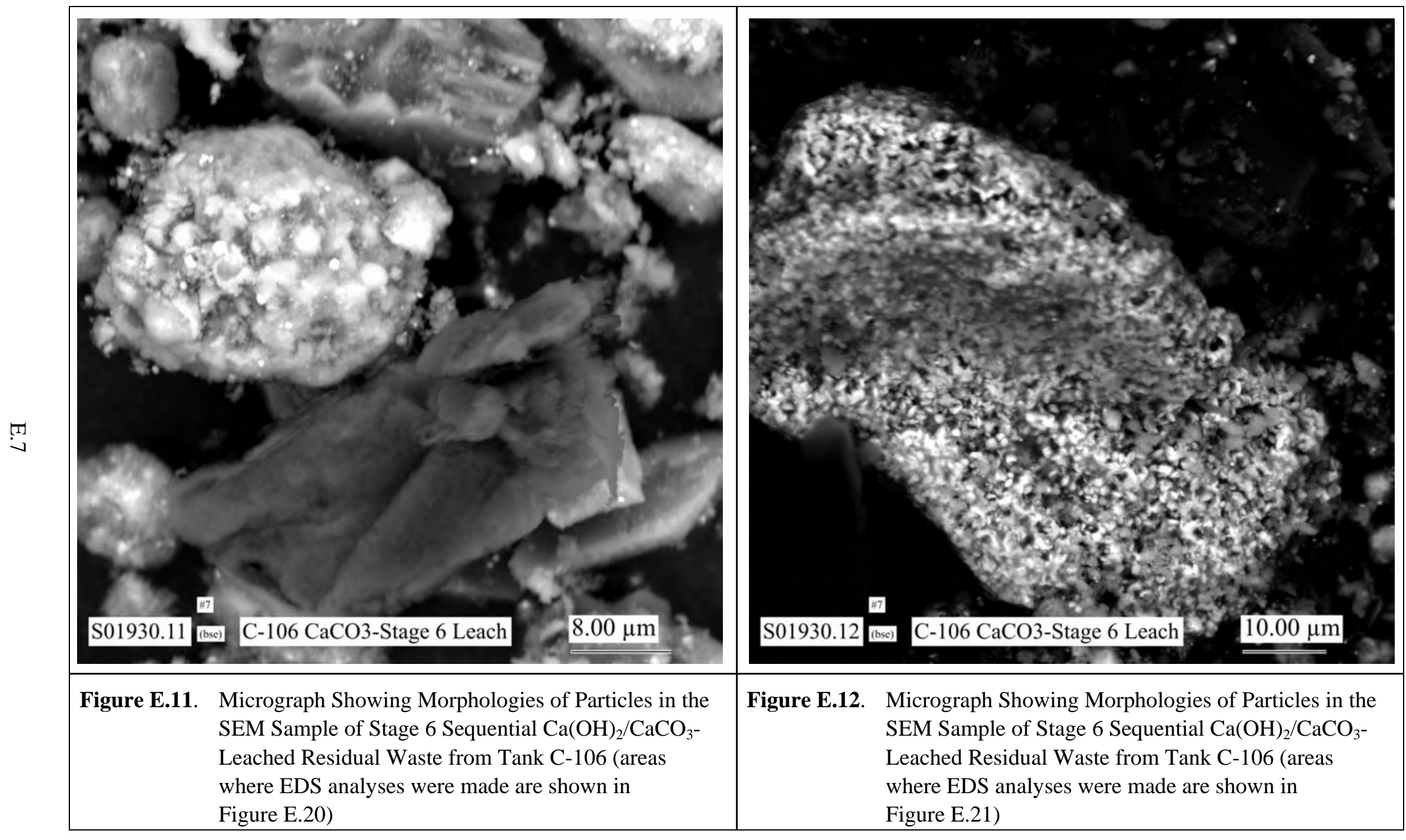




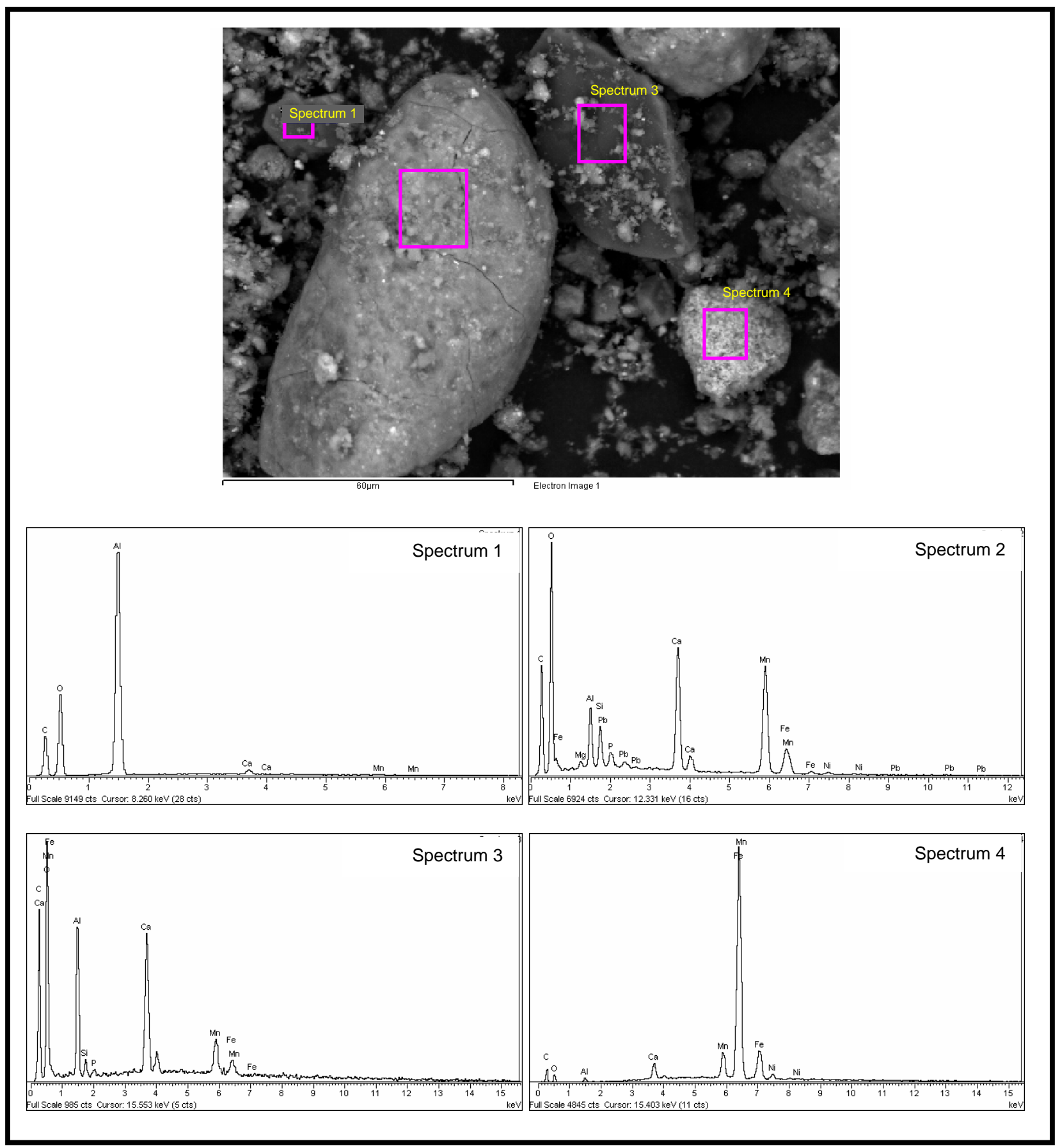

Figure E.13. EDS Spectra for Numbered Areas Marked in Pink in SEM Micrograph Shown at Top of Figure 


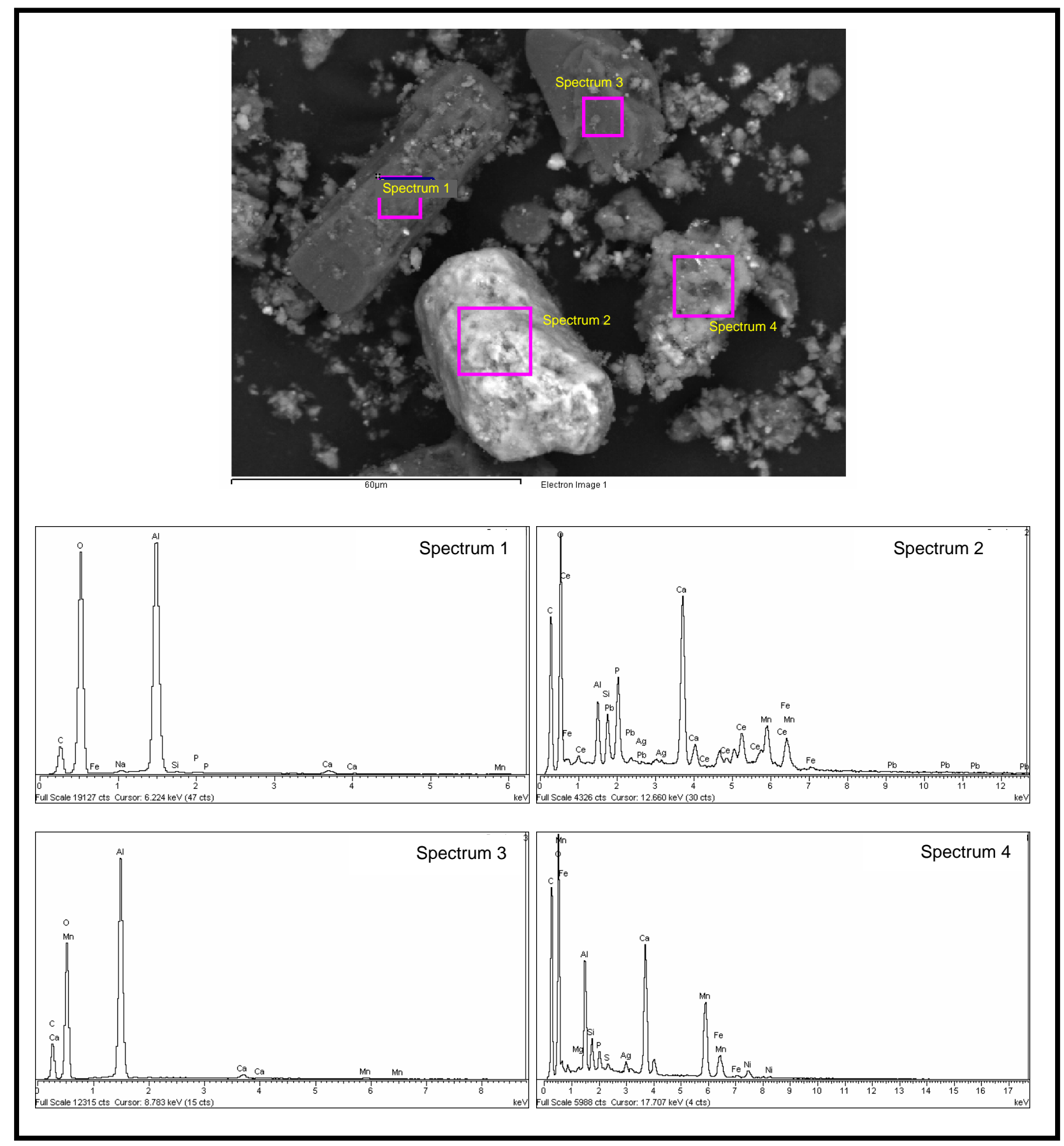

Figure E.14. EDS Spectra for Numbered Areas Marked in Pink in SEM Micrograph Shown at Top of Figure 


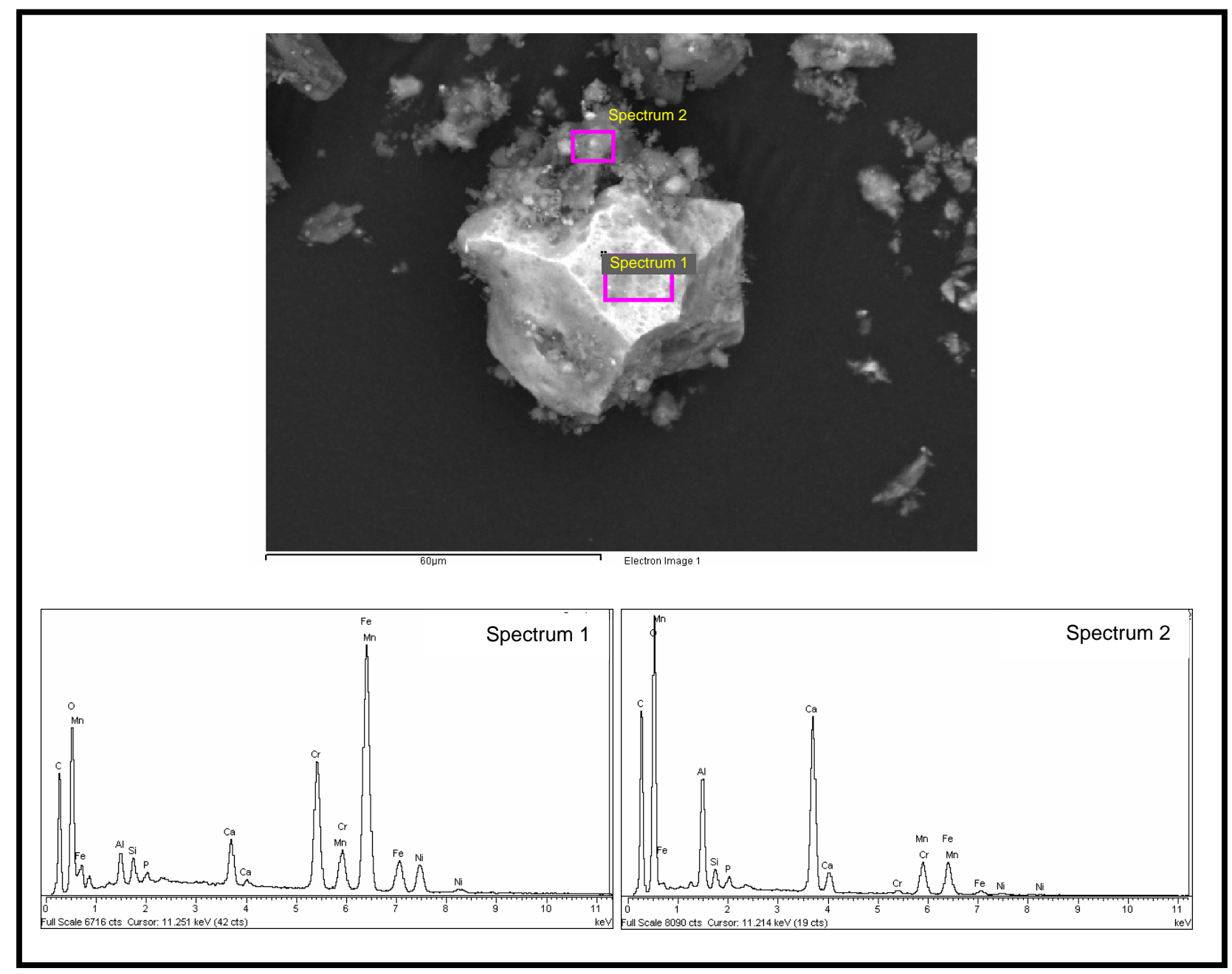

Figure E.15. EDS Spectra for Numbered Areas Marked in Pink in SEM Micrograph Shown at Top of Figure 


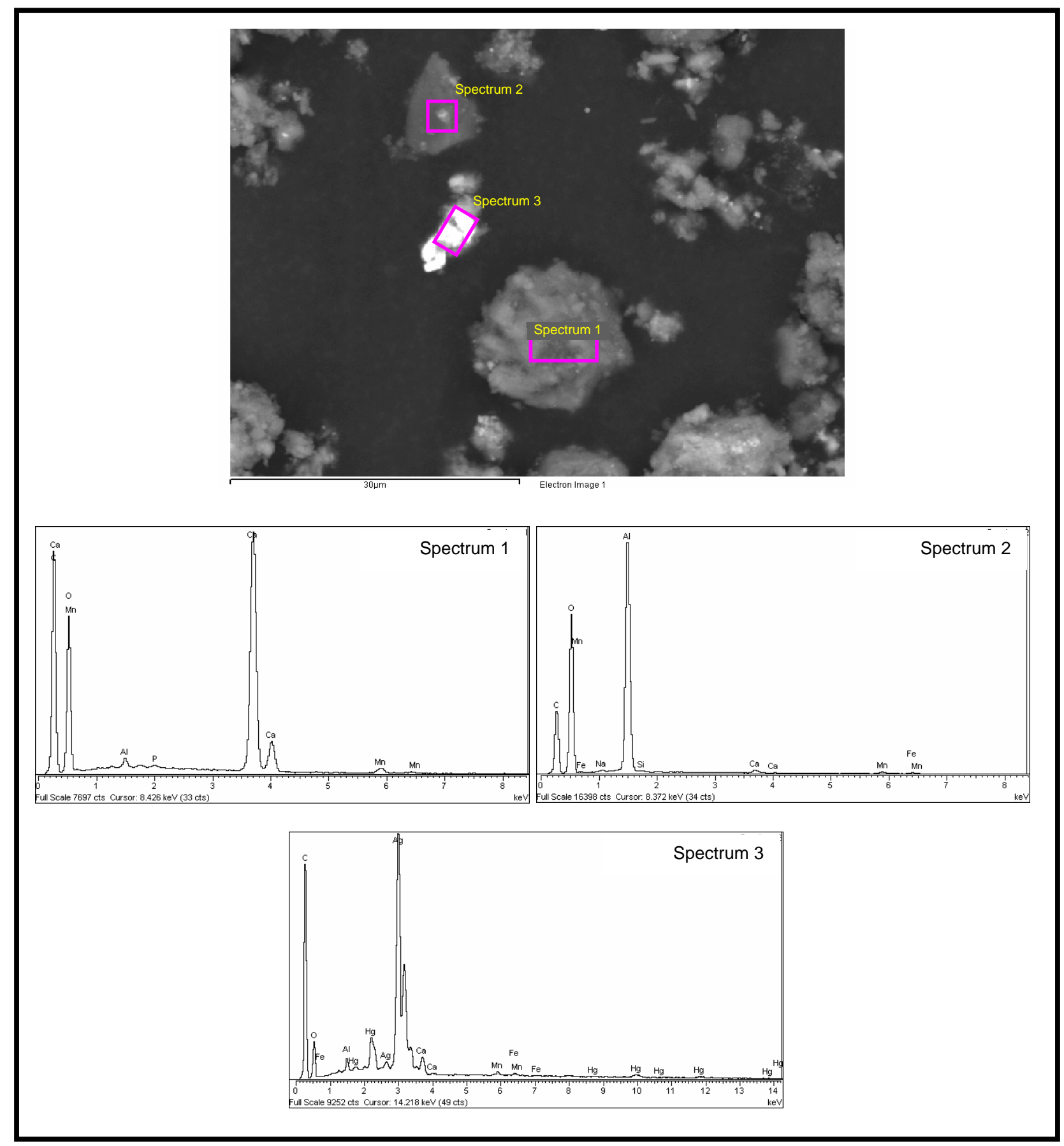

Figure E.16. EDS Spectra for Numbered Areas Marked in Pink in SEM Micrograph Shown at Top of Figure 


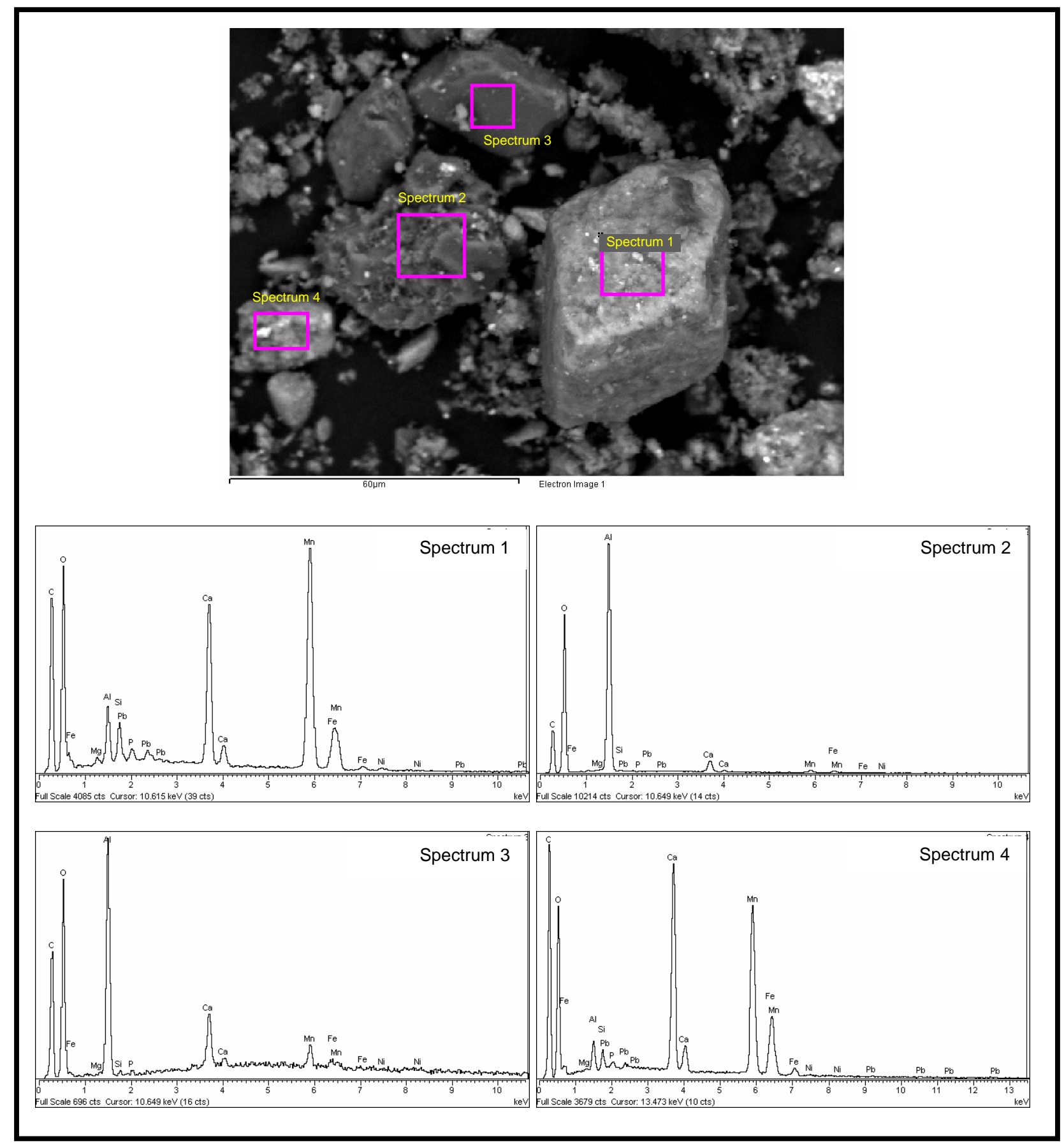

Figure E.17. EDS Spectra for Numbered Areas Marked in Pink in SEM Micrograph Shown at Top of Figure 


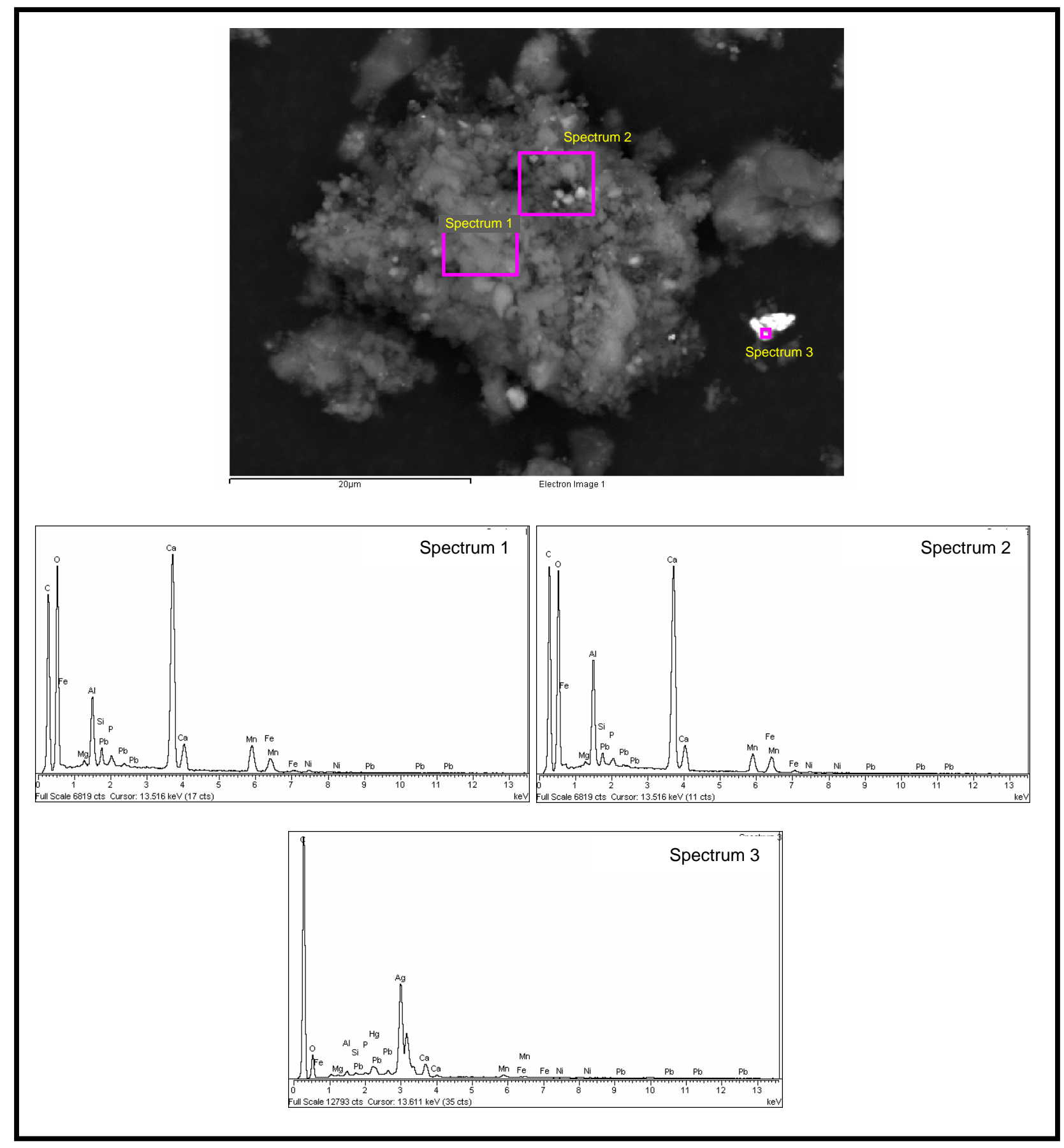

Figure E.18. EDS Spectra for Numbered Areas Marked in Pink in SEM Micrograph Shown at Top of Figure 


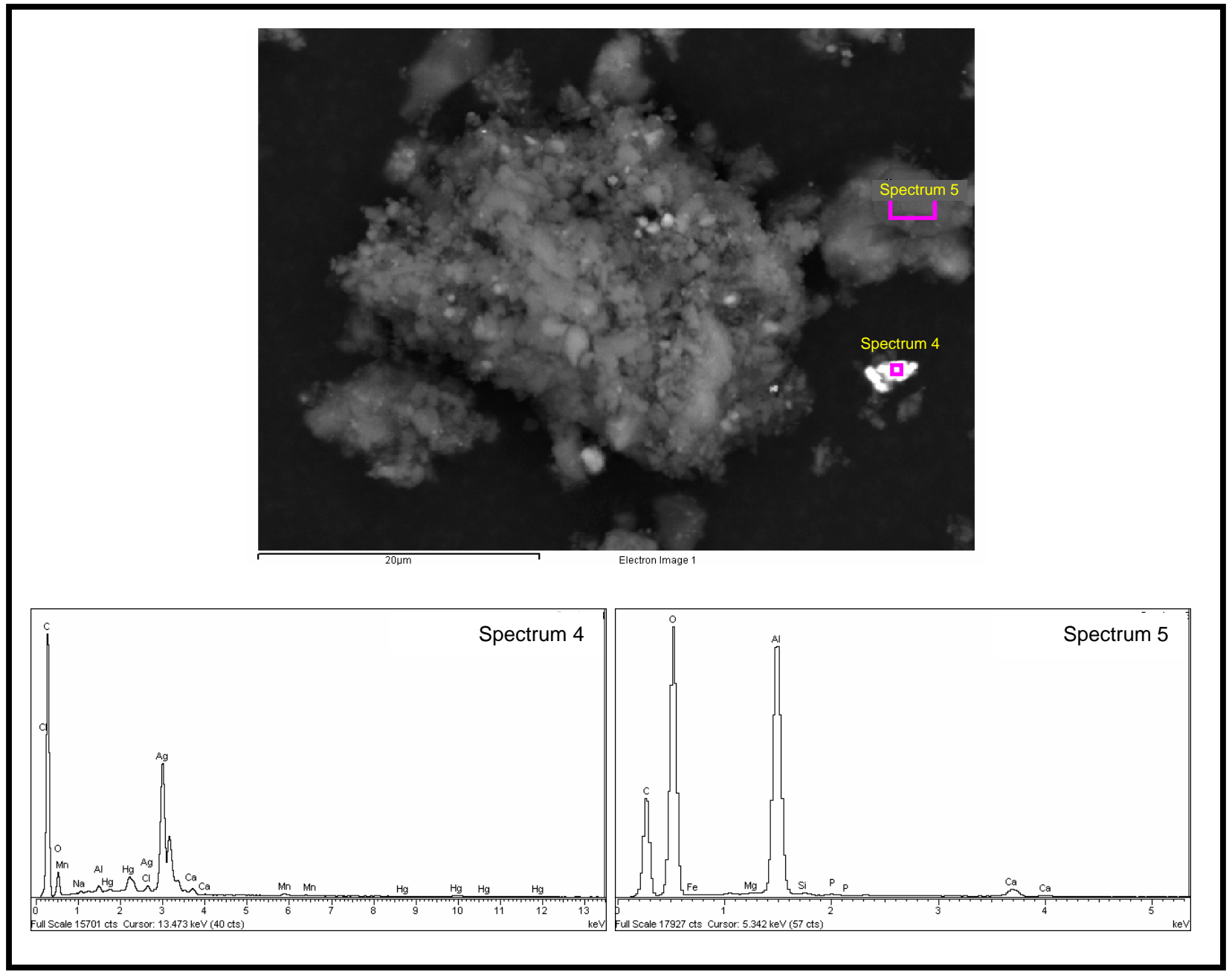

Figure E.19. EDS Spectra for Numbered Areas Marked in Pink in SEM Micrograph Shown at Top of Figure 


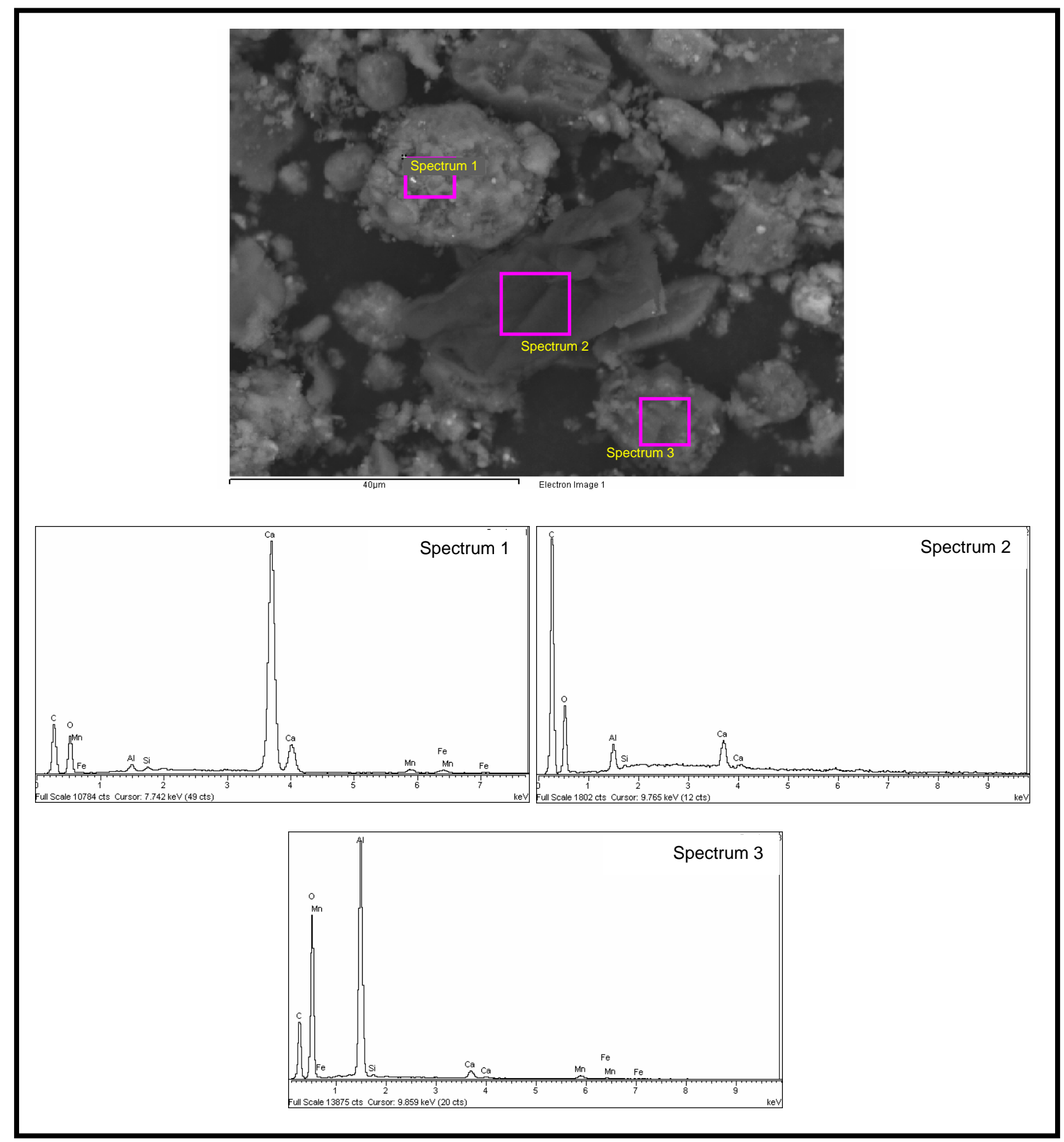

Figure E.20. EDS Spectra for Numbered Areas Marked in Pink in SEM Micrograph Shown at Top of Figure 


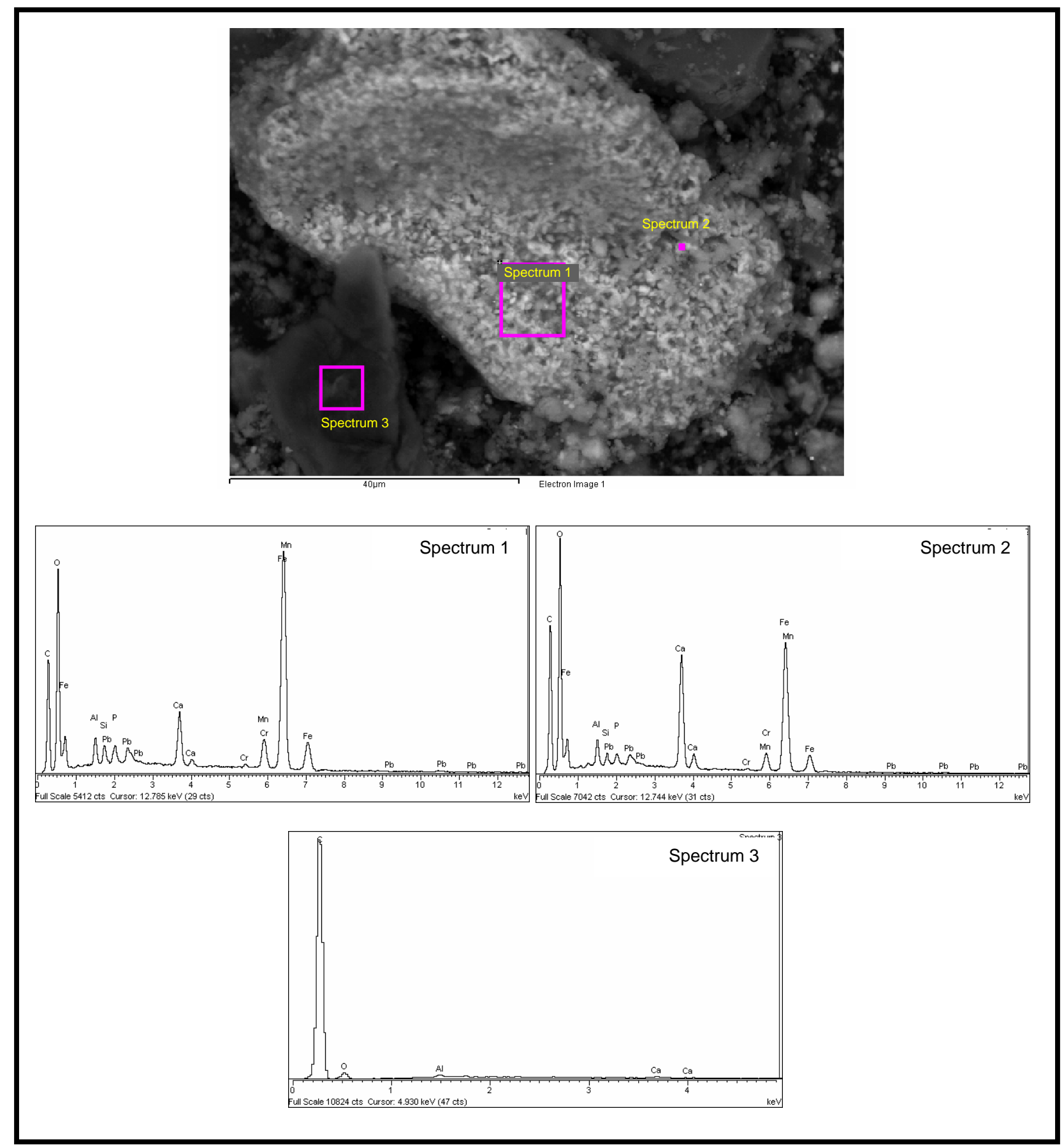

Figure E.21. EDS Spectra for Numbered Areas Marked in Pink in SEM Micrograph Shown at Top of Figure 


\section{Appendix F}

Solution Concentrations of Tank C-106 Solution Contact Tests with Residual Sludge 
Table F.1. Tank Chem $404 \mathrm{Ca}(\mathrm{OH})_{2}$

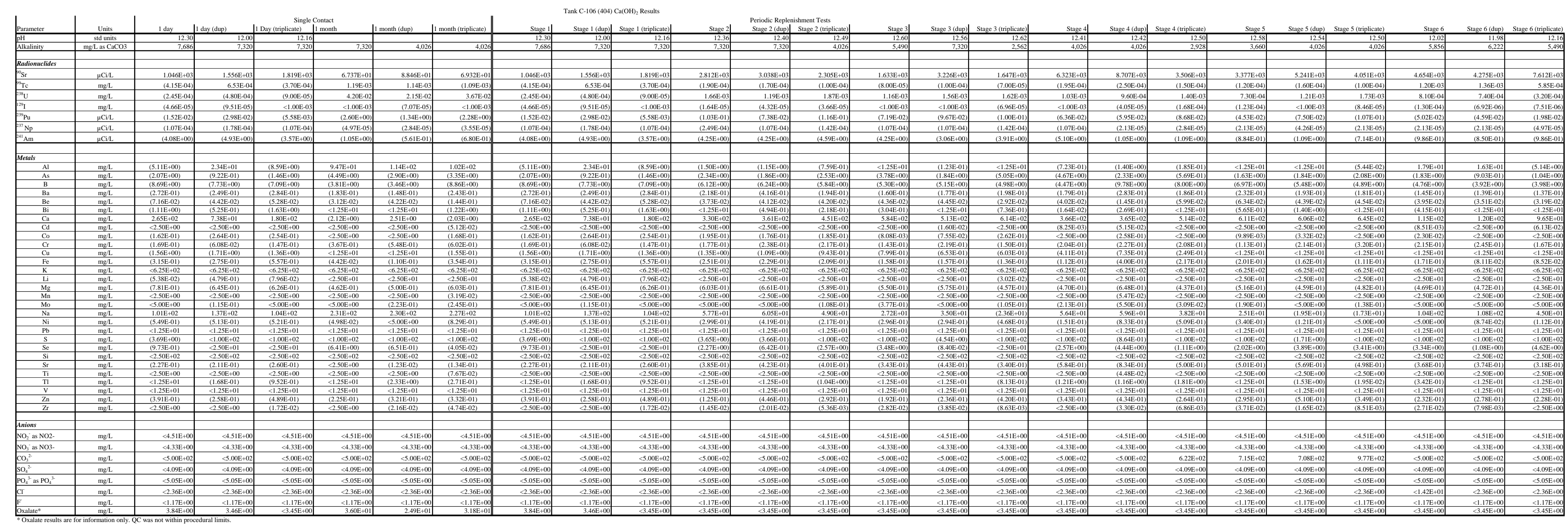


Table F.1. (contd)

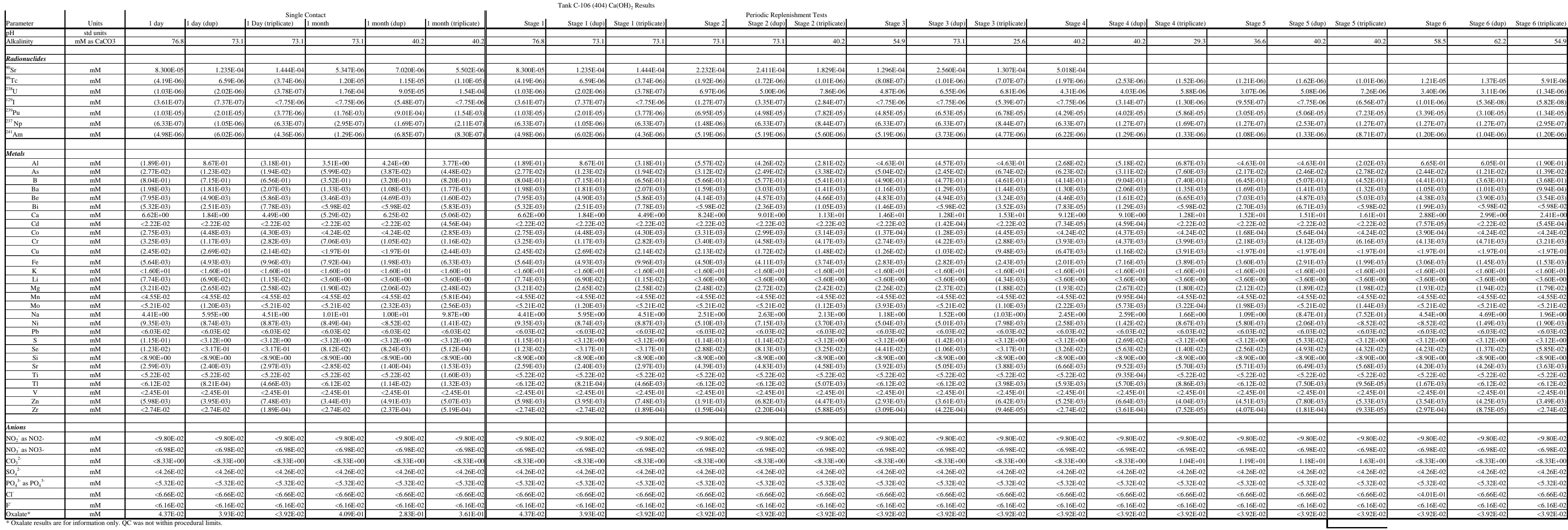


Table F.2. Tank $405 \mathrm{Ca}(\mathrm{OH})_{2}$

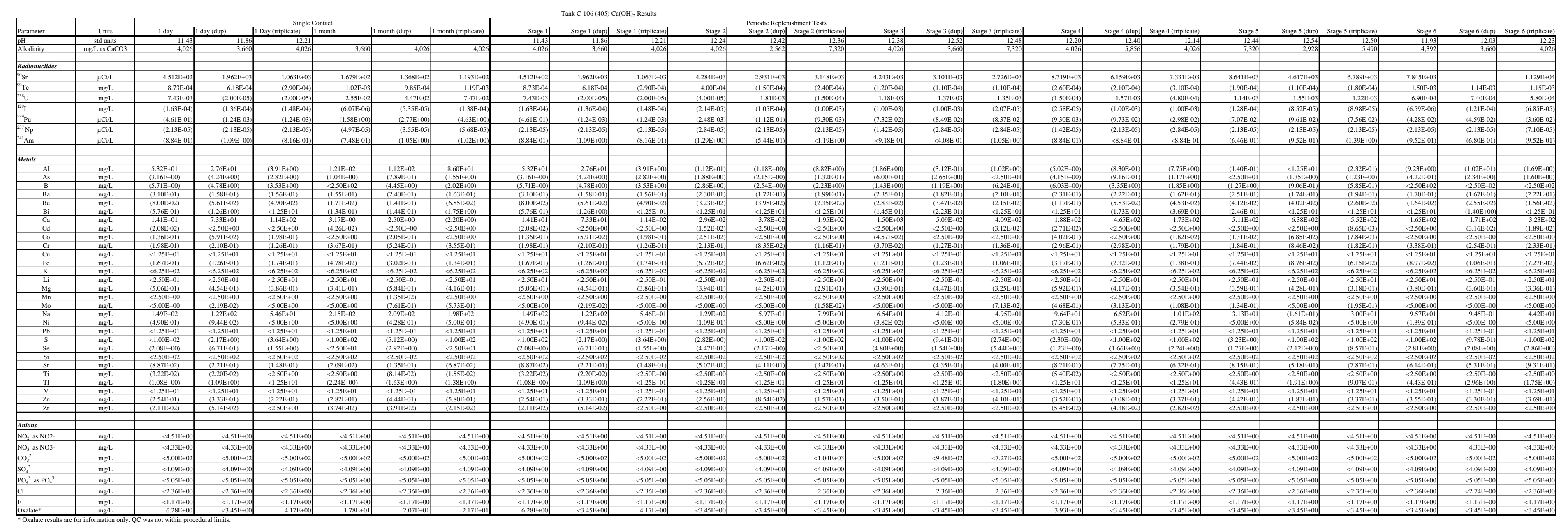




\section{Table F.2. (contd)}

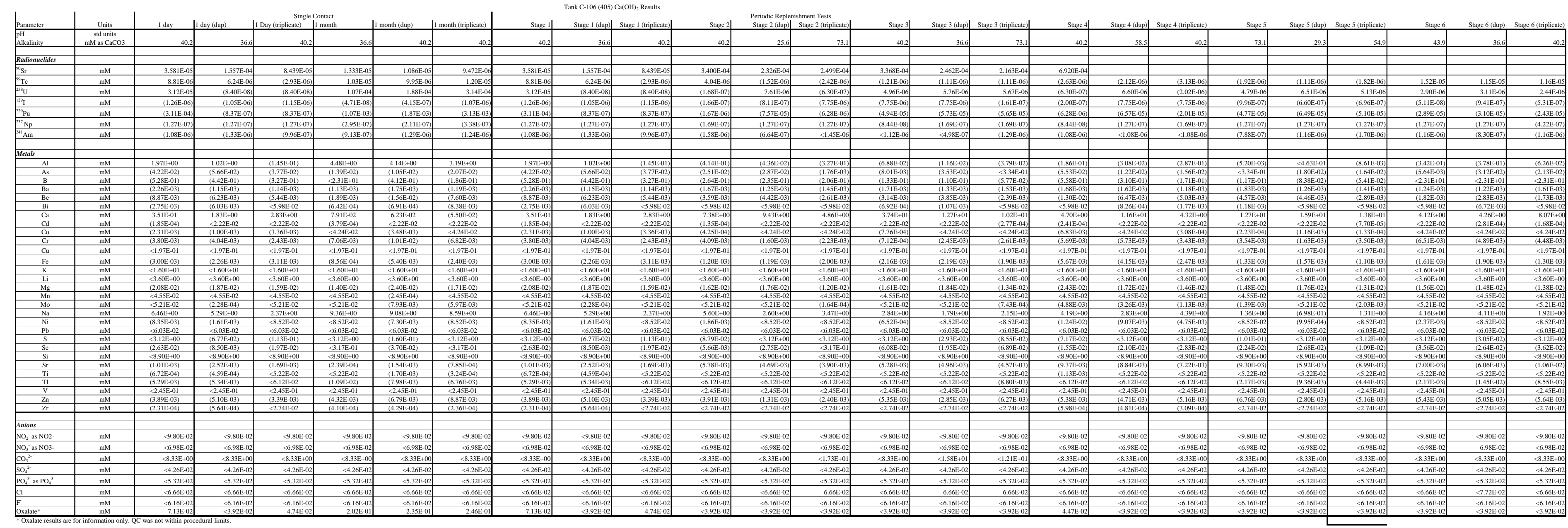


Table F.3. Tank Chem $404 \mathrm{CaCO}_{3}$

\begin{tabular}{|c|c|c|c|c|c|c|c|c|c|c|c|c|c|c|c|c|c|}
\hline \multicolumn{18}{|c|}{ Tank C-106 (404) $\mathrm{CaCO}_{3}$ Results } \\
\hline Parameter & Units & 1 dayl & $\begin{array}{l}\text { Singge } \\
1 \text { day (dup) }\end{array}$ & 1 month| & 1 month (dup) & Stage 1] & Stage 1 (dup) & Stage 2 $\mid$ & Stage 2 (dup) & $\begin{array}{l}\text { dic Reple } \\
\text { Stage } 3\end{array}$ & $\begin{array}{l}\text { ent Tests } \\
\text { Stage } 3 \text { (dup)| }\end{array}$ & Stage 4| & Stage 4 (dup) & Stage 5] & Stage 5 (dup) & Stage 6 & Stage 6 (dup) \\
\hline $\begin{array}{ll}\text { pH } \\
\text { Alkalinivy }\end{array}$ & 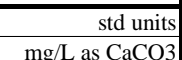 & $\begin{array}{l}11.45 \\
4.026 \\
\end{array}$ & $\begin{array}{l}11.54 \\
4.26\end{array}$ & 3,660 & 2.928 & $\begin{array}{ll}11.45 \\
4.2626\end{array}$ & $\begin{array}{l}11.54 \\
4.026 \\
\end{array}$ & $\begin{aligned} 11.51 \\
4.026 \\
\end{aligned}$ & $\begin{array}{l}11.47 \\
4.026 \\
\end{array}$ & $\begin{array}{ll}11.52 \\
4026\end{array}$ & $\begin{array}{r}11.38 \\
5.856\end{array}$ & $\begin{array}{l}11.45 \\
4.026 \\
\end{array}$ & $\begin{array}{r}11.39 \\
4.026\end{array}$ & $\begin{array}{l}11.14 \\
2562 \\
\end{array}$ & $\begin{array}{r}11.37 \\
4.026 \\
\end{array}$ & $\begin{array}{ll}11.75 \\
4.026\end{array}$ & $\begin{array}{l}11.74 \\
4.026\end{array}$ \\
\hline \multirow{2}{*}{\multicolumn{18}{|c|}{$\begin{array}{l}\text { Radionuclides } \\
\text { sos }_{\text {Sa }}\end{array}$}} \\
\hline & & & & & & & & & & & & & & & & & \\
\hline & $\mathrm{mg} / \mathrm{L}$ & $(5.50 \mathrm{E}-05)$ & $(4.00 \mathrm{E}-05)$ & $(3.40 \mathrm{E}-04)$ & $|(3.88 \mathrm{E}-44)|$ & $\mid(5.50 \mathrm{E}-55)$ & $(4.00 \mathrm{E}-55)$ & $\mid(5.00 \mathrm{E}-5)$ & $(6.00 \mathrm{E}-05)$ & $(4.00 \mathrm{E}-05)$ & $\mid(3.00 \mathrm{E}-5)$ & $(7.00 \mathrm{E}-5)$ & $(5.00 \mathrm{E}-05)$ & $(5.00 \mathrm{E}-05)$ & $(5.00 \mathrm{E}-05)$ & $(3.05 \mathrm{E}-04)$ & $(2.60 \mathrm{E}-04)$ \\
\hline${ }^{238} \mathrm{U}$ & $\mathrm{mgL}$ & $6.68 \mathrm{E}-04$ & $(4.70 \mathrm{E}-04)$ & 5.21E - 2 & 4.688-02 & $6.68 \mathrm{E}-04$ & $(4.70 \mathrm{DE}-44)]$ & $7.50 \mathrm{E}-04$ & $8.50 \mathrm{E}-04$ & $1.01 \mathrm{E}-03$ & $(4.90 \mathrm{E}-04)]$ & $9.30 \mathrm{E}-04$ & $9.40 \mathrm{E}-04$ & $(4.40 \mathrm{E}-04)]$ & 8.60E-04 & $8.90 \mathrm{E}-04$ & $9.60 \mathrm{E}-04$ \\
\hline${ }^{129}$ & $\mathrm{mgL}$ & $(8.74 \mathrm{E}-05)$ & $(6.51 \mathrm{E}-05)$ & & & $(8.74 \mathrm{E}-05)$ & $(6.51 E-05)]$ & $(7.31 E-05) \mid$ & $<1.00 \mathrm{E}-03$ & $(1.22 E-05)$ & $(1.26 \mathrm{E}-04)]$ & $(5.81 \mathrm{E}-05)]$ & $(2.01 \mathrm{E}-04)]$ & $(1.04 \mathrm{E}-04)$ & $(1.69 E-04) \mid$ & $(1.89 E-04)$ & $(3.79 \mathrm{E}-05$ \\
\hline${ }^{23} \mathrm{~s}_{\mathrm{pu}}$ & $\mu \mathrm{C} / \mathrm{i} L$ & $(1.86 \mathrm{E}-03)]$ & $(2.48 \mathrm{E}-03)$ & $(4.34 E-03)$ & $(3.10 \mathrm{E}-33)$ & $(1.86 \mathrm{E}-03) \mid$ & $(2.48 \mathrm{E}-03)]$ & $(3.10 \mathrm{E}-03)]$ & $(1.86 \mathrm{E}-03)$ & $(1.86 \mathrm{E}-03)$ & $(2.48 \mathrm{E}-03)]$ & $(2.48 \mathrm{E}-03)]$ & $(1.86 \mathrm{E}-03)]$ & $(4.34 \mathrm{E}-03)$ & $(1.86 \mathrm{E}-03)$ & $(3.72 \mathrm{E}-03)$ & $(2.48 \mathrm{E}-03)$ \\
\hline${ }^{237} \mathrm{~Np}$ & «CiLt & $(2.84 \mathrm{E}-05)]$ & $(2.13 \mathrm{E}-05)$ & $(6.398--05)$ & $(5.68 \mathrm{E}-05)$ & $(2.84 \mathrm{E}-05) \mid$ & $(2.13 \mathrm{E}-05)]$ & $(2.84 \mathrm{E}-05)]$ & $(2.84 \mathrm{E}-05)$ & $(1.42 E-05)$ & $(2.13 \mathrm{E}-05)]$ & $(1.42 \mathrm{E}-05)]$ & $(1.42 \mathrm{E}-05)$ & $(2.13 \mathrm{E}-05)]$ & $(2.13 \mathrm{E}-05)$ & $(7,10 \mathrm{E}-06)$ & $(7.10 \mathrm{E}-06)$ \\
\hline${ }^{244} \mathrm{Am}$ & $\mu \mathrm{CiJL}$ & $(9.18 \mathrm{E}-01)$ & $(6.80 \mathrm{E}-01)$ & $(1.09 E+00)]$ & $(6.12 \mathrm{E}-01)$ & $\begin{array}{l}(9.18 \mathrm{E}-01) \\
\end{array}$ & $\begin{array}{ll}(6.80 \mathrm{E}-01) \\
\end{array}$ & $(8.50 \mathrm{E}-101)$ & $(7.48 \mathrm{E}-01)$ & $(9.52 \mathrm{E}-01)$ & $(1.05 \mathrm{E}+00)$ & $(1.02 E+00)]$ & $(9.18 \mathrm{E}-01)$ & $(8.84 \mathrm{E}-01)$ & $(8.84 \mathrm{E}-01)$ & $<1.70 \mathrm{E}+00$ & $<1.70 \mathrm{E}+00$ \\
\hline & \multicolumn{17}{|c|}{ Metals } \\
\hline Al & & $2.45 \mathrm{E}+01$ & 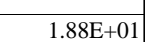 & $\mid(8.28 \mathrm{E}+00)$ & 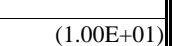 & $2.45 \mathrm{E}+01 \mid$ & $1.88 \mathrm{E}+01$ & 3.77E+01| & \begin{tabular}{|l|l|}
$4.56 \mathrm{E}+01$ \\
\end{tabular} & $5.01 E+01$ & \begin{tabular}{|c|c|}
$2.4 \mathrm{E}+011$ \\
\end{tabular} & $4.23 \mathrm{E}+011$ & 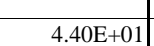 & $187 \mathrm{E}+01$ & $3.70 \mathrm{E}+01$ & $4.41 \mathrm{E}+01$ & \\
\hline & $\mathrm{mg} / \mathrm{L}$ & $(1.05 \mathrm{E}+00)$ & $(2.56 \mathrm{E}+00))$ & 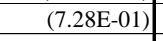 & $<2.50 \mathrm{E}+01$ & $\frac{1.05 E+00)}{(1.05+1}$ & $\frac{(2.56 \mathrm{E}+00)}{(2)}$ & $(2.51 \mathrm{E}+00)$ & $<2.50 \mathrm{E}+01$ & $\frac{(3.21 \mathrm{E}+00)}{(3)}$ & $(3.59 \mathrm{E}+00)$ & $\frac{(2.50 \mathrm{E}+00)}{(2)}$ & $\frac{1}{(2.295-01)}$ & $(3.01 E+00)$ & $(7.20 \mathrm{E}-01)$ & $(3.08 \mathrm{E}-01)$ & $\frac{.4001}{(7.10 \mathrm{E}-02)}$ \\
\hline & $\mathrm{mglL}$ & 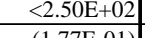 & 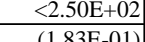 & $\begin{array}{l}2.50 \mathrm{~S} 0 \mathrm{E}+02 \\
\end{array}$ & $<2.50 \mathrm{CE}+02]$ & $\begin{array}{l}2.5 .5 \mathrm{E}+02+02 \\
.75 \mathrm{~F}\end{array}$ & $\begin{array}{c}2.50 \mathrm{SOE}+02] \\
{[.02]}\end{array}$ & $<2.50 \mathrm{EE}+02\}$ & $\begin{array}{l}<.50 \mathrm{E}+02 \\
-0.00702\end{array}$ & 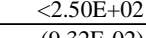 & $\begin{array}{c}<.5 .50 \mathrm{E}+02] \\
\end{array}$ & 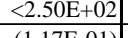 & $<2.50 \mathrm{E}+02]$ & $(2.39 E+00)]$ & $\begin{array}{l}2.5 .50 \mathrm{E}+02] \\
\end{array}$ & $(1.48 \mathrm{E}+00)$ & $(1.37 \mathrm{E}+00)$ \\
\hline & $\frac{1 \mathrm{mgL}}{\mathrm{mgl|}}$ & 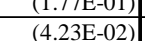 & 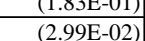 & $\mid$ & 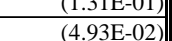 & 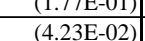 & 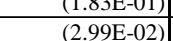 & $\mid$ & 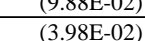 & $\frac{(9.362-02)}{(2.806-02)}$ & 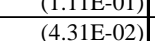 & $(2.10-10-0)$ & $\frac{(1.156-1)}{(2.56-2)}$ & 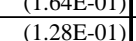 & 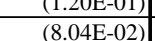 & {$\left[\begin{array}{l}(0.065-2) \\
(1.04-02)\end{array}\right.$} & $(5.12 \mathrm{E}-02)$ \\
\hline & $\frac{m g / L}{m g l}$ & 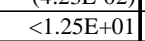 & (7.422E-01) & $<1.25 \mathrm{E}+01$ & $<1.25 \mathrm{E}+01$ & 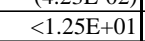 & (7..42E-01) & $\mid(3.15 \mathrm{E}-01)$ & $\begin{array}{l}(3.95 \mathrm{E}-02) \\
(1.70 \mathrm{E}+00)\end{array}$ & $\begin{array}{l}\left.\frac{(2.08 \mathrm{E}-02)}{<1.25 \mathrm{E}+01}\right) \\
\end{array}$ & 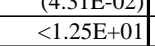 & $\begin{array}{l}(2.30 \mathrm{E}-02) \\
\langle 1.25 \mathrm{E}+01\end{array}$ & $\begin{array}{l}(.2 .0 \mathrm{E}-0 .-02) \\
(5.29 \mathrm{-011})\end{array}$ & $\begin{array}{l}(1.28 \mathrm{E}-1) \\
<1.25 \mathrm{E}+01\end{array}$ & (3.04-62-02) & $\begin{array}{l}(1.46-202) \\
<1.25 \mathrm{E}+00\end{array}$ & $\frac{(0.4 \mathrm{E}-\mathrm{-}-0)}{(1.37 \mathrm{E})}$ \\
\hline & $\mathrm{mg} / \mathrm{L}$ & $7.90 \mathrm{E}+01$ & $6.69 \mathrm{E}+01$ & $1.29 \mathrm{E}+02$ & $1.26 \mathrm{E}+02$ & $\begin{array}{l}7.90 \mathrm{E}+011 \\
\end{array}$ & $6.69 \mathrm{E}+01$ & \begin{tabular}{|c|c|}
$1.07 \mathrm{E}+02$ \\
\end{tabular} & $1.21 \mathrm{E}+02$ & $1.33 \mathrm{E}+02$ & $6.93 \mathrm{E}+01$ & \begin{tabular}{|c|}
$1.12 \mathrm{E}+02$ \\
\end{tabular} & $1.12 \mathrm{E}+02$ & $5.29 \mathrm{E}+01$ & $9.30 \mathrm{E}+01$ & $1.12 \mathrm{E}+02$ & $9.28 \mathrm{E}+01$ \\
\hline & $\mathrm{mg} / \mathrm{L}$ & $<2.50 \mathrm{E}+000$ & $<2.50 \mathrm{E}+00$ & $<2.50 \mathrm{E}+00$ & $(2.25 \mathrm{E}-02)$ & $<2.50 \mathrm{E}+00$ & 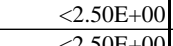 & $(8.81 E-22)$ & $<2.50 \mathrm{E}+00$ & $<2.50 \mathrm{E}+00$ & $<2.50 \mathrm{E}+00$ & $<2.50 \mathrm{E}+00$ & $<2.50 \mathrm{E}+00$ & $(6.32 \mathrm{E}-02)$ & $(6.18 \mathrm{E}-02)$ & $<2.50 \mathrm{E}-01$ & $<2.50 \mathrm{E}-01$ \\
\hline & $\mathrm{mglL}$ & 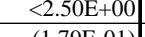 & $<2.50 \mathrm{EE}+000$ & $<2.50 \mathrm{SE}+000$ & $<2.50 \mathrm{E}+00]$ & 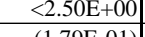 & $<2.50 \mathrm{E}+000$ & 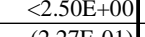 & $<2.50 \mathrm{E}+00$ & $(1.60 \mathrm{E}-022)$ & 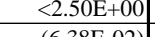 & 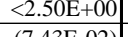 & 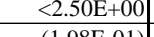 & {$\left[\begin{array}{l}(9.91 \mathrm{E}-02)] \\
10-2)\end{array}\right.$} & $\begin{array}{l}2.5 .50 \mathrm{E}+000 \\
\end{array}$ & $(6.05 E-022)]$ & $(4.46 E-02)$ \\
\hline & mgle & 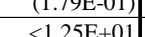 & 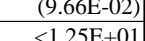 & 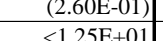 & 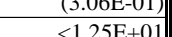 & 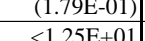 & 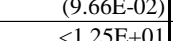 & 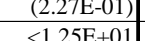 & 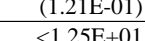 & 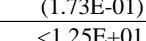 & 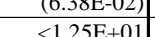 & 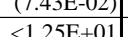 & $\mid$ & 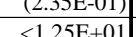 & 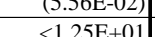 & 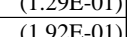 & $\frac{1.1 .164-01}{(170-01}$ \\
\hline & $\mathrm{mg} / \mathrm{L}$ & $\frac{\mid 1.20 \mathrm{E}-02}{(7.04 \mathrm{E}-02)} \mid$ & $\frac{1.2 .5 \mathrm{E}+\mathrm{*}-1}{(9.42)}$ & $\begin{array}{l}-1.25 \mathrm{E}-01 \\
(1.93 \mathrm{E}-01)\end{array}$ & 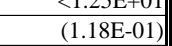 & $\frac{11.25 \mathrm{E}+\mathrm{F} 1}{(7.04 \mathrm{E})}$ & $\begin{array}{l}-1.25 \mathrm{E}-01 \\
(9.54 \mathrm{E}-02)\end{array}$ & $\mid \begin{array}{cc}1.2 .25 \mathrm{E}+01 \\
<2.00\end{array}$ & $\frac{1.2 .3 \mathrm{E}+\mathrm{F}-1}{(2.11)}$ & $\frac{1.20 \mathrm{E}-\mathrm{F}-1}{(4.86 \mathrm{E}-2)}$ & $\frac{1.2 .4 E-02}{(2.44 \mathrm{E}-02)}$ & (1.2.70E-02) & $\begin{array}{l}-1.25 \mathrm{EE}-02 \\
(5.20 \mathrm{-})\end{array}$ & $\begin{array}{l}(2.280 \mathrm{E}-01) \\
(2.01)\end{array}$ & $\frac{1.2 .25 E+01}{(1.395-01)}$ & $\begin{array}{l}(1.92 \mathrm{E}-01) \\
(2.16 \mathrm{E}-01)\end{array}$ & $\left(\begin{array}{l}(1.00 E-01 \\
(1.901)\end{array}\right.$ \\
\hline & $\mathrm{mgl}$ & $\begin{array}{l}<6.25 \mathrm{E}+02 \\
\end{array}$ & $<6.25 \mathrm{E}+02$ & $<6.25 \mathrm{E}+02$ & $<6.25 \mathrm{E}+02$ & 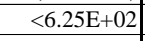 & $<6.25 \mathrm{E}+02$ & 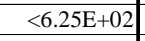 & $<6.25 \mathrm{E}+02$ & $<6.25 \mathrm{E}+02$ & 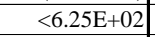 & $<6.25 \mathrm{E}+022$ & $<6.25 \mathrm{E}+022$ & $<6.25 \mathrm{E}+02$ & $\begin{array}{ll}<6.25 \mathrm{E}+02 \\
\end{array}$ & $\begin{array}{l}(1.19 E+00) \\
(5)\end{array}$ & $\langle 1.25 \mathrm{E}+0.2$ \\
\hline Li] & $\mathrm{mgl} / \mathrm{I}$ & $\begin{array}{c}<.5 .50 \mathrm{E}+01] \\
\end{array}$ & $<2.50 \mathrm{E}+01$ & {$[2.50 \mathrm{E}+01]$} & $\langle 2.50 \mathrm{E}+01]$ & $\begin{array}{l}2.50 \mathrm{EE}+01 \\
\end{array}$ & $<2.50 \mathrm{E}+01$ & $<2.50 \mathrm{E}+01]$ & $<2.50 \mathrm{E}+01$ & $<2.50 \mathrm{E}+01$ & $<2.50 \mathrm{E}+01]$ & $<2.50 \mathrm{E}+01]$ & $\langle 2.50 \mathrm{E}+01]$ & $<2.50 \mathrm{E}+01]$ & $<2.5 \mathrm{E}+011$ & $(3.56 \mathrm{E}-02)$ & $\begin{array}{ll}(4.56 \mathrm{E}-02 \\
\end{array}$ \\
\hline & $\mathrm{mglL}$ & $\frac{(3.76-10-01)}{(-60)}$ & 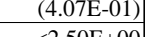 & 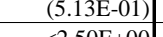 & $\frac{(3.395-101)}{(350-1)}$ & $\frac{(3,76 \mathrm{E}-0.01)}{-601}$ & 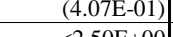 & $\frac{(3.67 \mathrm{E}-0.1)}{(352)}$ & $\frac{(3.85 \mathrm{E}-01)}{(101)}$ & $\frac{(3.06 \mathrm{E}-011)}{\left(\frac{10}{2}\right)}$ & $\frac{(4.26 \mathrm{E}-01)}{4601)}$ & $\frac{(3.38 \mathrm{E}-01)}{-(50-1)}$ & $\frac{(3.21 \mathrm{E}-01)}{-(10-1)}$ & 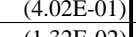 & 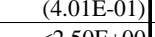 & 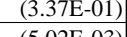 & $\frac{(2.22 \mathrm{E}-01)}{(2201)}$ \\
\hline & mgl & & (2097.01) & (1) & $550 \mathrm{~F}+000$ & (2) & (2075 (1) & $550 \mathrm{~s}$ & 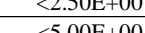 & 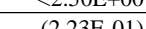 & 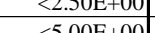 & 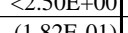 & $550 \mathrm{~s}$ & (1552) & (A6F-01) & 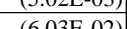 & $\begin{array}{l}1.25 E-01 \\
10.025\end{array}$ \\
\hline & $\frac{1 \mathrm{mgL}}{\mathrm{mglL}}$ & $\begin{array}{l}(2.4 .4 E-10) \\
(4.66+00)\end{array}$ & $(1.31 \mathrm{E}+0)$ & 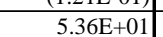 & $\frac{5.066+1}{5.46 \mathrm{E}+01}$ & $(4.66 \mathrm{E}+0)$ & $(1.311+0) 0)$ & $\mid$ & $(1.93 \mathrm{E}+00)$ & $\frac{1.256-1)}{(7.368-0.1)}$ & $<2.05 \mathrm{E}+00$ & (3.19E+0) & $\frac{(5.20 \mathrm{E}+00)}{(5)+0}$ & 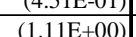 & $(4.64 \mathrm{EE}-01)$ & $\begin{array}{ll}(6.303 E-02) \\
(3.76+0)\end{array}$ & $(.1 .05 \mathrm{E}+00)$ \\
\hline & $\mathrm{mg} / \mathrm{L}$ & $(2.93 \mathrm{E}-01)$ & $(1.42 E-01)$ & $(6.13 \mathrm{E}-02)$ & $<5.00 \mathrm{E}+00$ & $(2.93 \mathrm{E}-01)$ & $(1.42 \mathrm{E}-01)$ & $<5.00 \mathrm{E}+00$ & $<5.00 \mathrm{E}+00$ & $\frac{(7.97 \mathrm{E}-02)}{(1)}$ & $(3.05 E-02)$ & $<5.00 \mathrm{E}+00$ & $<5.00 \mathrm{E}+00$ & $\left(\begin{array}{ll}(8.93 \mathrm{E}-00) \\
(1+1)\end{array}\right.$ & $(3.54 \mathrm{E}-01)$ & $(1.02 \mathrm{E}-01)$ & $(7.75 \mathrm{E}-02$ \\
\hline & $\mathrm{mg} / \mathrm{L}$ & $\begin{array}{l}<1.25 \mathrm{E}+01 \\
4.02\end{array}$ & $<1.25 \mathrm{E}+01$ & $<1.25 \mathrm{E}+01$ & $<1.25 \mathrm{E}+011$ & $<1.25 \mathrm{E}+01$ & $<1.25 \mathrm{E}+01$ & $\langle 1.25 \mathrm{E}+01$ & $<1.25 \mathrm{E}+01$ & $<1.25 \mathrm{E}+01$ & $<1.25 \mathrm{E}+01$ & $<1.25 \mathrm{E}+01$ & $<1.25 \mathrm{E}+01$ & $<1.25 \mathrm{E}+01$ & $<1.25 \mathrm{E}+01$ & $<1.25 \mathrm{E}+00$ & $(6.90 \mathrm{E}-03)$ \\
\hline & $\mathrm{mg} / \mathrm{L}$ & 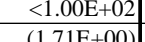 & $\frac{(2.16 E+00)}{205 \mathrm{E}+01}$ & $<1.00 \mathrm{E}+02)$ & $\begin{array}{c}<.00 \mathrm{E}+02 \\
(3.35 \mathrm{E}+0)\end{array}$ & $\begin{array}{l}1.00 \mathrm{E}+02 \\
{[117 \mathrm{~F}+02)}\end{array}$ & $\begin{array}{l}(2.16 \mathrm{E}+00) \\
205 \mathrm{E}+01\end{array}$ & $\frac{(1.01 E-01)}{(1.15+0.02)}$ & $\begin{array}{c}1.00 \mathrm{E}+02 \\
(3.23 \mathrm{~F}+000\end{array}$ & $\begin{array}{c}1.00 \mathrm{E}+02 \\
(3.3 \mathrm{~F}+000\end{array}$ & 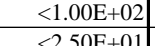 & 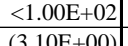 & $\begin{array}{l}(3.00 \mathrm{E}+00) \\
(8.5 \mathrm{E}-0 \mathrm{01})\end{array}$ & $<1.00 \mathrm{E}+02$ & $\begin{array}{ll}(3.83 E+00) \\
250 \mathrm{~F}+01\end{array}$ & $(1.26 E-01)$ & $<5.00 \mathrm{E}+00$ \\
\hline & moL & 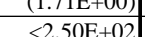 & 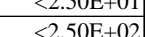 & 2 & 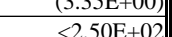 & 2 & 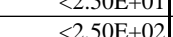 & 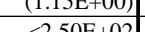 & 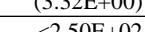 & 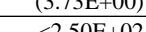 & 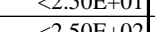 & 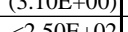 & $(8.25 \mathrm{E}-0.01)$ & $(3.15+0.007)$ & 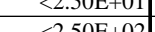 & 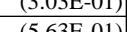 & 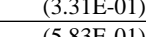 \\
\hline & $\frac{\mathrm{mgl}}{\mathrm{mg} / \mathrm{L}}$ & $\frac{2.0 .0 E-02}{(1.23-01)}$ & 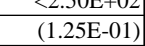 & $\mid(4.12 \mathrm{E}-02)$ & 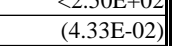 & $\mid(1.23 \mathrm{E}-01)$ & $\frac{(1.25 \mathrm{E}-01)}{\left(\frac{1}{2}\right.}$ & $\frac{(1.49 \mathrm{E}-01)}{(1)}$ & 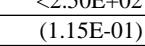 & $\begin{array}{l}(1.323 \mathrm{E}-02 \\
(1)\end{array}$ & $\begin{array}{l}2.2 .05 E+02 \\
(4.55-02)\end{array}$ & 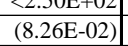 & 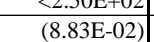 & 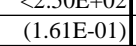 & $\begin{array}{l}2.0 .06 \mathrm{E}-02 \\
(1.12 \mathrm{E}-01)\end{array}$ & $\begin{array}{l}(3.0 .05 E-11) \\
(1.05 E-01)\end{array}$ & $\frac{(5.8 .8 \mathrm{E}-01)}{(6.82 \mathrm{E}-02)}$ \\
\hline & $\mathrm{mg} / \mathrm{L}$ & $\mid(1.11 E-02)$ & $<2.50 \mathrm{E}+00$ & & $(1.59 \mathrm{E}-02)$ & $(1.11 \mathrm{E}-02)$ & $<2.50 \mathrm{E}+00$ & $<2.50 \mathrm{E}+00$ & $<2.50 \mathrm{E}+00$ & $<2.50 \mathrm{E}+00$ & $<2.50 \mathrm{E}+00$ & $<2.50 \mathrm{E}+00$ & $<2.50 \mathrm{E}+00$ & $(7.43 \mathrm{E}-02)$ & $\begin{array}{l}(2.87 \mathrm{E}-02) \\
\end{array}$ & $<2.50 \mathrm{E}-01$ & $(5.51 \mathrm{E}-03$ \\
\hline & $\mathrm{mg} / \mathrm{L}$ & $\frac{(2.28 \mathrm{E}+00)}{2.20 \mathrm{~T})}$ & $(1.33 \mathrm{E}+00)$ & $(1.47 \mathrm{E}-01)$ & $\begin{array}{l}<1.25 \mathrm{E}+01 \\
1.2501\end{array}$ & 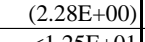 & $\frac{(1.33 E+00)}{1.5201}$ & $(1.20 \mathrm{E}+00)]$ & $(6.35 \mathrm{E}-01)$ & $<1.25 \mathrm{E}+01$ & $(5,46 \mathrm{E}-01)$ & $\frac{(2.07 E+00)}{120 \Gamma 0)}$ & $(7.99 \mathrm{E}-01)$ & $(4.71 E-01)]$ & $\begin{array}{l}<1.25 \mathrm{E}+01 \\
12 \mathrm{~T}+101\end{array}$ & $<2.50 \mathrm{E}+000$ & $<2.50 \mathrm{E}+0$ \\
\hline & $\frac{m g L}{m \sigma h}$ & 盗, & 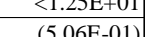 & 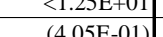 & 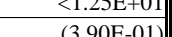 & 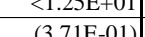 & $\mid$ & 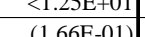 & 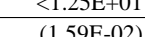 & 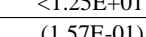 & 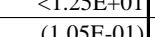 & 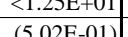 & $\frac{1.205-01}{648 \mathrm{~F}-01}$ & 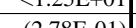 & 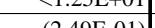 & & 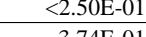 \\
\hline$\frac{2 n}{77}$ & $\frac{\mathrm{mgL}}{\mathrm{mg} / \mathrm{L}}$ & $<2.50 \mathrm{E}+00$ & $\frac{1.250 \mathrm{E}+00}{<-200}$ & $(3.98 \mathrm{E}-1)$ & $\frac{1.86-22)}{(9.96-02)}$ & $<2.50 \mathrm{E}+00 \mid$ & 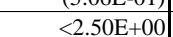 & $\frac{\mid(3.78 \mathrm{E}-2)}{(1)}$ & $\frac{1.250 \mathrm{E}+00}{<2.5 \mathrm{E}}$ & $\frac{(1.5 / \mathrm{E}-01)}{<2.50 \mathrm{E}+00}$ & $<2.50 \mathrm{E}+00$ & (8.295-03) & $<2.50 \mathrm{E}+00$ & $(3.14-\mathrm{E}-2)$ & $\frac{1.250+10}{<2.50 \mathrm{E}+00}$ & $\langle 1.43 \mathrm{E}-02$ & $\frac{3.74 \mathrm{E}-\mathrm{-1}}{(2.72 \mathrm{E})}$ \\
\hline \multicolumn{18}{|l|}{$\begin{array}{c}\text { Anions } \\
\end{array}$} \\
\hline $\mathrm{NO}_{2}$ as $\mathrm{NO}_{2}$ & $\begin{array}{c}\mathrm{mg} / \mathrm{L} \\
\end{array}$ & 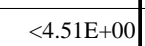 & $\begin{array}{l}<4.51 \mathrm{E}+00 \\
\end{array}$ & $<4.51 \mathrm{E}+00 \mid$ & $|<4.51 \mathrm{E}+00|$ & $<4.51 \mathrm{E}+00$ & $\mid<4.51 \mathrm{E}+00$ & $<4.51 \mathrm{E}+00$ & $<4.51 \mathrm{E}+00$ & $<4.51 \mathrm{E}+00$ & $|<4.51 E+00|$ & $<4.51 \mathrm{E}+00 \mid$ & $<4.51 E+00$ & $<4.51 E+00$ & $<4.51 E+00$ & $<4.51 \mathrm{E}+00$ & $<4.51 E+00$ \\
\hline $\mathrm{NO}_{3}^{-}$as $\mathrm{NO} 3-$ & $\mathrm{mg} / \mathrm{L}$ & $<4.33 \mathrm{E}+00$ & $<4.33 \mathrm{E}+00$ & $<4.33 \mathrm{E}+00$ & $<4.33 \mathrm{E}+00 \mid$ & $<4.33 \mathrm{E}+00$ & $<4.33 \mathrm{E}+00$ & $<4.33 \mathrm{E}+0 \mid$ & $<4.33 \mathrm{E}+00$ & $<4.33 \mathrm{E}+00$ & $<4.33 \mathrm{E}+00$ & $<4.33 \mathrm{E}+00$ & $<4.33 \mathrm{E}+00$ & $<4.33 \mathrm{E}+00$ & $<4.33 \mathrm{E}+00$ & $<4.33 \mathrm{E}+00$ & $<4.33 \mathrm{E}+00$ \\
\hline $\mathrm{CO}_{3}^{2}$ & $\mathrm{mg} / \mathrm{L}$ & $<5.00 \mathrm{E}+02$ & $<5.00 \mathrm{E}+02$ & $<5.00 \mathrm{E}+22$ & $<5.00 \mathrm{E}+02$ & $<5.00 \mathrm{E}+02$ & $<5.00 \mathrm{E}+02$ & $<5.00 \mathrm{E}+22$ & $<5.00 \mathrm{E}+02$ & $<5.00 \mathrm{E}+02$ & $<5.00 \mathrm{E}+22$ & $<5.00 \mathrm{E}+02$ & $<5.00 \mathrm{E}+02$ & $<5.00 \mathrm{E}+22$ & $<5.00 \mathrm{E}+02$ & $<5.00 \mathrm{E}+02$ & $<5.00 \mathrm{E}+02$ \\
\hline $\mathrm{SO}_{4}{ }^{2}$ & $\mathrm{mgL}$ & $<4.09 E+00$ & $<4.09 \mathrm{E}+00$ & $<4.09 \mathrm{E}+00 \mid$ & $1.65 \mathrm{E}+01$ & $<4.09 \mathrm{E}+00$ & $<4.09 \mathrm{E}+00$ & $<4.09 E+00$ & $<4.09 \mathrm{E}+00$ & $<4.09 \mathrm{E}+00$ & $<4.09 \mathrm{E}+00$ & $<4.09 \mathrm{E}+00$ & $<4.09 \mathrm{E}+00$ & $<4.09 \mathrm{E}+00$ & $<4.09 \mathrm{E}+00$ & $<4.09 \mathrm{E}+00$ & $<4.09 \mathrm{E}+00$ \\
\hline $\mathrm{P}_{4}{ }^{3}$ as $\mathrm{P}_{4}$ & $\mathrm{mgLL}$ & $<5.05 \mathrm{E}+00$ & $<5.05 \mathrm{E}+00$ & $<5.05 \mathrm{E}+00 \mid$ & $<5.05 \mathrm{E}+00$ & $<5.05 \mathrm{E}+00$ & $<5.05 \mathrm{E}+00$ & $<5.05 \mathrm{E}+00$ & $<5.05 \mathrm{E}+00$ & $<5.05 \mathrm{E}+00$ & $<5.05 \mathrm{E}+00$ & $<5.05 \mathrm{E}+00$ & $<5.05 \mathrm{E}+00$ & $<5.05 \mathrm{E}+00$ & $<5.05 \mathrm{E}+00$ & $<5.05 \mathrm{E}+00$ & $<5.05 \mathrm{E}$ \\
\hline & $\mathrm{mgL}$ & $<2.36 \mathrm{E}+00$ & $<2.36 \mathrm{E}+00$ & $<2.36 \mathrm{E}+00$ & $<2.36 \mathrm{E}+00$ & $<2.36 \mathrm{E}+00$ & $<2.36 \mathrm{E}+00$ & $<2.36 \mathrm{E}+00$ & $<2.36 \mathrm{E}+00$ & $<2.36 \mathrm{E}+00$ & $<2.36 \mathrm{E}+00$ & $<2.36 \mathrm{E}+0 \mid$ & $<2.36 \mathrm{E}+00$ & $<2.36 \mathrm{E}+00$ & $<2.36 \mathrm{E}+00$ & $<2.36 \mathrm{E}+00$ & $<2.36 \mathrm{E}+00$ \\
\hline $\mathrm{F}$ & $\mathrm{mg} / \mathrm{L}$ & $<1.17 \mathrm{E}+00$ & $<1.17 \mathrm{E}+00$ & $<1.17 \mathrm{E}+00$ & $<1.17 \mathrm{E}+00$ & $<1.17 \mathrm{E}+00$ & $<1.17 \mathrm{E}+00$ & $<1.17 \mathrm{E}+00$ & $<1.17 \mathrm{E}+00$ & $<1.17 \mathrm{E}+00$ & $<1.17 \mathrm{E}+00$ & $<1.17 \mathrm{E}+00$ & $<1.17 \mathrm{E}+00$ & $<1.17 \mathrm{E}+00$ & $<1.17 \mathrm{E}+00$ & $<1.17 \mathrm{E}+00$ & 1.1.17E+ +00 \\
\hline & & & & & & & & & $<3.45 \mathrm{E}+00$ & & & & & & & & $3.45 \mathrm{E}+00$ \\
\hline
\end{tabular}


Table F.3. (contd)

\begin{tabular}{|c|c|c|c|c|c|c|c|c|c|c|c|c|c|c|c|c|c|}
\hline \multicolumn{18}{|c|}{ Tank C-106 (404) $\mathrm{CaCO}_{3}$ Results } \\
\hline $\begin{array}{l}\text { Parameter } \\
\text { rht }\end{array}$ & Units & 1 day & 1 day (dup) & 1 month, & 1 month (dup) & Stage 1 1 & Stage 1 (dup) & Stage 2 & & Stage 3 & Stage 3 (dup) & Stage 4 & Stage 4 (dup) & Stage 5 & Stage 5 (dup) & Stage 6 . & Stage 6 (dup) \\
\hline Alkalinity & 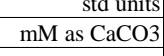 & 40.2 & 40.2 & 36.6 & 29.3 & 40.2 & 40.2 & 40.2 & 40.2 & 40.2 & 58.5 & 40.2 & 40.2 & 25.6 & 40.2 & 40.2 & 40.2 \\
\hline $\begin{array}{l}\text { Radionuclides } \\
\end{array}$ & & & & & & & & & & & & & & & & & \\
\hline & $\mathrm{mM}$ & $9.354 \mathrm{E}-05$ & $1.817 \mathrm{E}-04$ & & & $\begin{array}{l}9.354 \mathrm{E}-05 \\
\end{array}$ & $1.817 \mathrm{E}-04$ & $\begin{array}{l}1.145 \mathrm{E}-04 \\
\end{array}$ & $1.130 \mathrm{E}-04$ & 3.395E-05 & $1.472 \mathrm{E}-05$ & $8.711 \mathrm{E}-05$ & 5.555E-05 & $2.779 \mathrm{E}-05$ & $5.398 \mathrm{E}-05$ & & \\
\hline & $\mathrm{mM}$ & $(5.56 \mathrm{E}-07)$ & $(4.04 \mathrm{E}-07)$ & $(3.43 E-06)$ & $(3.91 E-06)$ & $(5.56 \mathrm{E}-07)$ & $(4.04 E-07) \mid$ & $(5.05 E-07)$ & $(6.06 E-07)$ & $(4.04 \mathrm{E}-07)$ & $(3.03 E-07)$ & $(7.07 E-07)$ & $(5.05 E-07)$ & $(5.05 E-07)$ & $(5.05 E-07)$ & $(3.08 E-06)$ & $(2.63 \mathrm{E}-06)$ \\
\hline & $\mathrm{mm}$ & $2.80 \mathrm{E}-06$ & $(1.978-06)$ & $2.19 \mathrm{E}-04$ & $1.97 \mathrm{E}-04$ & $2.80 \mathrm{E}-06$ & $(1.97 \mathrm{E}-06)$ & $3.15 E-06$ & 3.57E-06 & 4.24E-06 & $(2.06 \mathrm{E}-06)$ & $3.91 E-06$ & $3.95 E-06$ & $(1.85 \mathrm{E}-06)$ & 3.61E-06 & 3.74E-06 & 4.03E-06 \\
\hline & $\mathrm{mM}$ & $(6.78 E-07)$ & $(5.05 \mathrm{E}-07)]$ & $0.00 \mathrm{E}+00$ & $0.00 \mathrm{E}+00$ & $(6.78 \mathrm{E}-07)]$ & $(5.05 \mathrm{E}-77)]$ & & & & & & & & & $(1.47 \mathrm{E}-06)]$ & \\
\hline${ }^{239} \mathrm{Pu}$ & $\mathrm{mM}$ & $(1.26 \mathrm{E}-06)$ & $(1.67 \mathrm{E}-06) \mid$ & $(2.93 \mathrm{E}-06)$ & $(2.09 E-06)$ & $(1.26 \mathrm{E}-06)$ & $(1.67 \mathrm{E}-06)$ & $(2.09 \mathrm{E}-06)$ & $(1.26 \mathrm{E}-06)$ & $(1.26 \mathrm{E}-06)$ & $(1.67 \mathrm{E}-06)$ & $(1.67 \mathrm{E}-06)$ & $(1.26 \mathrm{E}-06)$ & $(2.93 \mathrm{E}-06)$ & $(1.26 \mathrm{E}-06)$ & $(2.51 \mathrm{E}-06)$ & $(1.67 E-06)$ \\
\hline 型 & $\mathrm{mM}$ & $(1.69 \mathrm{E}-07)$ & $(1.27 E-07)]$ & $(3.80 \mathrm{E}-07)]$ & $(3.38 \mathrm{E}-07)$ & $(1.69 \mathrm{E}-07)$ & $(1.27 \mathrm{E}-07)]$ & $(1.69 \mathrm{E}-07)]$ & $(1.69 E-07) \mid$ & $(8.44 \mathrm{E}-08)$ & $(1.27 \mathrm{E}-07)$ & $(8.44 \mathrm{E}-08)$ & $(8.44 \mathrm{E}-08)$ & $(1.27 \mathrm{E}-07)$ & $(1.27 \mathrm{E}-07)]$ & $(4.22 \mathrm{E}-08)$ & $(4.22 \mathrm{E}-08)$ \\
\hline 年4 & $\mathrm{mM}$ & $(1.12 \mathrm{E}-06)$ & $(8.30 \mathrm{E}-07)]$ & $(1.33 \mathrm{E}-06)$ & $(7.47 \mathrm{E}-07)$ & $(1.12 \mathrm{E}-06)]$ & $(8.30 \mathrm{E}-077]$ & $(1.04 \mathrm{E}-06)$ & $(9.13 E-07)$ & $(1.16 \mathrm{E}-06)$ & $(1.29 \mathrm{E}-06)$ & $(1.24 \mathrm{E}-06)$ & $(1.12 \mathrm{E}-06)]$ & $(1.08 \mathrm{E}-06)]$ & $(1.08 \mathrm{E}-06)]$ & $<2.07 \mathrm{E}-06$ & $<2.07 \mathrm{E}-06$ \\
\hline Meorts & & & & & & & & & & & & & & & & & \\
\hline Al & $\mathrm{mM}$ & $9.07 \mathrm{E}-01$ & & $(3.07 \mathrm{E}-01)]$ & $(3.72 \mathrm{E}-01)$ & \begin{tabular}{|c|}
$9.07 \mathrm{E}-01$ \\
\end{tabular} & $6.96 \mathrm{E}-01$ & $1.38 \mathrm{E}+00$ & $1.69 \mathrm{E}+00$ & $1.86 \mathrm{E}+00$ & 9.77E-01] & $1.57 \mathrm{E}+00$ & $|1.63 \mathrm{E}+00|$ & 6.95E-01 & \begin{tabular}{|c|}
$1.37 \mathrm{E}+00$ \\
\end{tabular} & $1.63 \mathrm{E}+00$ & \\
\hline & & & & & $<3.34 \mathrm{E}-01$ & & & $\frac{3.35 \mathrm{E}-02)}{(3)}$ & $<3.34 \mathrm{E}-01$ & & (4.79E-02) & & $(3.05 \mathrm{E}-03)$ & & $(9.62 \mathrm{E}-03)$ & 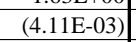 & $(9.48 \mathrm{E}-04)$ \\
\hline & $\mathrm{mM}$ & $<2.31 \mathrm{E}+01$ & $<2.31 \mathrm{E}+01$ & $<2.31 \mathrm{E}+01$ & $<2.31 \mathrm{E}+01$ & $<2.31 \mathrm{E}+01$ & $<2.31 E+01$ & $<2.31 \mathrm{E}+01$ & $<2.31 \mathrm{E}+01$ & $<2.31 \mathrm{E}+01$ & $<2.31 \mathrm{E}+01$ & $<2.31 \mathrm{E}+01$ & $<2.31 \mathrm{E}+01$ & $(2.21 \mathrm{E}-01)$ & $<2.31 \mathrm{E}+01$ & $(1.37 \mathrm{E}-01)$ & $(1.26 \mathrm{E}-01)$ \\
\hline & $\mathrm{mM}$ & $(1.29 \mathrm{E}-03)$ & $(1.33 \mathrm{E}-03)]$ & $(8.09 \mathrm{E}-04)$ & $(9.51 \mathrm{E}-04)]$ & 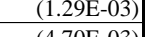 & $(1.33 \mathrm{E}-03)]$ & $(6.68 \mathrm{E}-04)$ & $(7.19 \mathrm{E}-04)]$ & 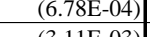 & $(8.09 \mathrm{E}-04)]$ & $(8.55 \mathrm{E}-04)]$ & $(8.36 \mathrm{E}-04)]$ & $\left(\begin{array}{l}(1.199-03) \\
(1.20)\end{array}\right.$ & $(8.76 \mathrm{E}-04)]$ & $(4.85 \mathrm{E}-04)]$ & $(3.73 \mathrm{E}-04)$ \\
\hline $\begin{array}{l}\text { Be } \\
\text { Be }\end{array}$ & min & 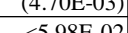 & 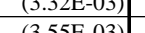 & $(3.6 / 2-03)$ & 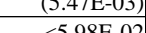 & 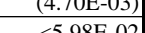 & (3.525-505) & $(3.018-03)$ & $(4.426-503)$ & $(3.110-03)$ & 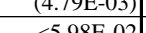 & 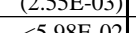 & $(2.845-(25)]$ & $(1 .-24 E-22)$ & $(8.920-000)$ & $(1.150-03)$ & $(9.14 \mathrm{E}-04)]$ \\
\hline Cal & $\mathrm{mm}$ & 1.97F+o0 & 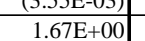 & 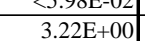 & $\frac{3.50-20}{3.15 \mathrm{E}+00}$ & $\frac{1.5060}{1.97 \mathrm{E}+0 \mathrm{O}}$ & $1.67+0$ & $2.66 \mathrm{E}+0$ & $3.1 \mathrm{E}+0 \mid$ & $3.32 \mathrm{E}+00$ & $1.73 \mathrm{E}+00$ & 2.8.5e & $2.78 \mathrm{E}+0 \mathrm{O}$ & $\frac{1.32 \mathrm{E}+00}{100}$ & 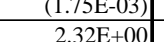 & $\begin{array}{l}2.300 \mathrm{~F} \\
280 \mathrm{~F}\end{array}$ & $\frac{(6.54 \mathrm{E}-0-0)}{231 \mathrm{E}+00}$ \\
\hline & $\mathrm{mm}$ & $<2.22 \mathrm{E}-02$ & $\langle 2.22 \mathrm{E}-02$ & $<2.22 \mathrm{E}-22$ & $(2.01 \mathrm{E}-04)$ & $<2.22 \mathrm{E}-02$ & $\langle 2.22 \mathrm{E}-22$ & $(7.84 \mathrm{E}-04)$ & $<2.22 \mathrm{E}-02$ & $<2.22 \mathrm{E}-02 \mid$ & $<2.22 \mathrm{E}-02$ & $<2.22 \mathrm{E}-02$ & $\langle 2.22 \mathrm{E}-22$ & $(5.62 \mathrm{E}-04)$ & $(5.49 \mathrm{E}-04)$ & $<2.22 \mathrm{E}-03$ & $=2.22 \mathrm{E}-03$ \\
\hline & $\mathrm{mM}$ & $<4.24 \mathrm{E}-02$ & $<4.24 \mathrm{E}-02$ & $<4.24 \mathrm{E}-02$ & $<4.24 \mathrm{E}-02$ & $<4.24 \mathrm{E}-02$ & $<4.24 \mathrm{E}-02$ & $<4.24 \mathrm{E}-22$ & $<4.24 \mathrm{E}-02$ & $(2.71 \mathrm{E}-04)$ & $<4.24 \mathrm{E}-02$ & $<4.24 \mathrm{E}-22$ & $<4.24 \mathrm{E}-2 \mid$ & $(1.68 \mathrm{E}-03)]$ & $<4.24 \mathrm{E}-22$ & $(1.03 \mathrm{E}-03)]$ & $(7.56 \mathrm{E}-04)$ \\
\hline & $\mathrm{mM}$ & 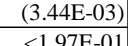 & $(1.86-803)]$ & (5.00-003)] & $(5.898-03)$ & $(3.440-03)$ & $(1.86-503) \mid$ & $(4.36-16-03)$ & $(2.32 \mathrm{E}-03)$ & $(3.32 \mathrm{~B}-0.3)$ & $(1.23 \mathrm{E}-03)$ & $(1.438-03)]$ & (3.80-80-03) & $(4.51 \mathrm{E}-0.03)]$ & $(1.07 \mathrm{E}-03) \mid$ & (2.299-E-3) & $(2.19 \mathrm{E}-03)]$ \\
\hline $\mathrm{Fe}$ & $\mathrm{mm}$ & $\frac{1.265-03)}{()^{2}}$ & $(1.171 \mathrm{-}-3)$ & (3.36E-03) & $\frac{1.31 \mathrm{E}-0.03)}{(2)}$ & $\mid$ & $\mid$ & $<4.48 \mathrm{E}-02$ & (1.445-03) & $(8.695-04)$ & $(1,375-04)$ & $(1.20-0) 3)$ & $(3.91-04)$ & $(5,015-03)$ & (250-03) & (3.037-0.3) & 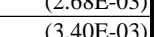 \\
\hline $\mathrm{K}$ & $\mathrm{mM}$ & $<1.60 \mathrm{E}+01$ & $<1.60 \mathrm{E}+01$ & $<1.60 \mathrm{E}+01$ & $<1.60 \mathrm{E}+01$ & $<1.60 \mathrm{E}+01$ & $<1.60 \mathrm{E}+01$ & $<1.60 \mathrm{E}+01$ & $<1.60 \mathrm{E}+01$ & $<1.60 \mathrm{E}+01$ & $<1.60 \mathrm{E}+01$ & $<160 \mathrm{~F}+01$ & $<1.60 \mathrm{E}+101$ & $<1.60 \mathrm{E}+01$ & $<1,60 \mathrm{~F}+01$ & $(3.048-02)$ & $<3.20 \mathrm{~F}+00$ \\
\hline $\mathrm{Li}$ & $\mathrm{mM}$ & $<3.60 \mathrm{E}+00$ & $<3.60 \mathrm{E}+00 \mid$ & $<3.60 \mathrm{E}+00 \mid$ & $<3.60 \mathrm{E}+00$ & $<3.60 \mathrm{E}+00$ & $\langle 3.60 \mathrm{E}+00|$ & $<3.60 \mathrm{E}+00$ & $<3.60 \mathrm{E}+00$ & $<3.60 \mathrm{E}+00$ & $<3.60 \mathrm{E}+00$ & $<3.60 \mathrm{E}+00$ & $<3.60 \mathrm{E}+00 \mid$ & $\langle 3.60 \mathrm{E}+00$ & $<3.60 \mathrm{E}+00$ & $(5.13 \mathrm{E}-03)$ & $(6.57 \mathrm{E}-03)$ \\
\hline $\mathrm{Mg}$ & $\mathrm{mM}$ & $(1.55 E-02)$ & $(1.67 \mathrm{E}-022)$ & $(2.11 \mathrm{E}-02)]$ & $(1.40 \mathrm{E}-02)$ & $(1.55 E-02)]$ & $(1.67 \mathrm{E}-022)$ & $(1.51 \mathrm{E}-02)$ & $(1.59 \mathrm{E}-02)$ & $(1.26 \mathrm{E}-02)$ & $(1.75 \mathrm{E}-02)$ & $(1.39 \mathrm{E}-02)$ & $(1.32 \mathrm{E}-22)]$ & $(1.66 \mathrm{E}-02)]$ & $(1.65 \mathrm{E}-02)]$ & $(1.39 \mathrm{E}-02)]$ & $\mid \begin{array}{c}9.13 E-03) \\
\end{array}$ \\
\hline $\mathrm{mo}$ & $\mathrm{min}$ & $\begin{array}{l}24.5 \mathrm{EE}-02 \\
0.5902\end{array}$ & 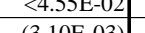 & 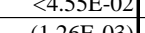 & $\begin{array}{l}24.55 E-02 \\
-530.02\end{array}$ & 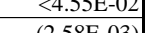 & 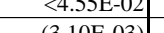 & 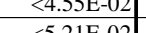 & 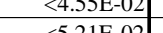 & 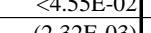 & 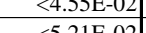 & 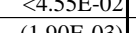 & 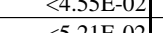 & 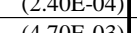 & 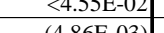 & 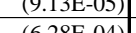 & 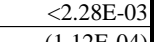 \\
\hline $\mathrm{Na}$ & $\mathrm{mm}$ & & & & & ) & (5.57) & $(1325040$ & (8) & (3) & . & 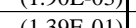 & 0.20001 & (14950 & & $(1,650)$ & 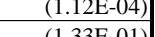 \\
\hline $\mathrm{Ni}_{\mathrm{Ni}}$ & $\mathrm{mm}$ & (5.000-03) & $(2.41 \mathrm{E}-03)$ & $\frac{(1.044-03)}{(1)}$ & $8.525-02$ & $(5.00 \mathrm{E}-03)$ & $(2.41 \mathrm{E}-03)$ & $<8.52 \mathrm{E}-02$ & $<8.52 \mathrm{E}-02$ & $(1.36 \mathrm{E}-03)$ & $(5,20 \mathrm{E}-04)$ & $\langle 855 \mathrm{E}-02$ & $\langle 852 \mathrm{E}-02|$ & (1.545e- & 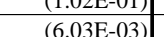 & $(1,735-3)$ & 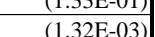 \\
\hline $\mathrm{Pb}$ & $\mathrm{mM}$ & $\begin{array}{c}<6.03 E-02 \\
\end{array}$ & $<6.03 \mathrm{E}-02$ & $<6.03 \mathrm{E}-22$ & $<6.03 \mathrm{E}-02$ & $<6.03 \mathrm{E}-02$ & $<6.03 \mathrm{E}-02$ & $<6.03 \mathrm{E}-02$ & $<6.03 \mathrm{E}-02$ & $<6.03 \mathrm{E}-02$ & $<6.03 \mathrm{E}-02$ & $<6.03 \mathrm{E}-02$ & $<6.03 \mathrm{E}-22$ & $<6.03 \mathrm{E}-02$ & $<6.03 \mathrm{E}-02$ & $<6.03 \mathrm{E}-03$ & (3.33-5 \\
\hline & mM & $<3.12 \mathrm{E}+00$ & $(6.74 \mathrm{E}-22)$ & $\langle 3.12 \mathrm{E}+00$ & $<3.12 \mathrm{E}+00$ & $<3.12 \mathrm{E}+00$ & $(6.74 \mathrm{E}-02)$ & $(3.14 \mathrm{E}-03)$ & $\langle 3.12 \mathrm{E}+00|$ & $<3.12 \mathrm{E}+00$ & $<3.12 \mathrm{E}+00$ & $\langle 3.12 \mathrm{E}+00$ & $(9.35 \mathrm{E}-02)$ & $<3.12 \mathrm{E}+0 \mid$ & $(1.19 \mathrm{E}-11)$ & $(3.93 \mathrm{E}-03)$ & $<1.56 \mathrm{E}-01$ \\
\hline se & $\mathrm{mm}$ & $\begin{array}{l}(2.16 \mathrm{E}-02) \\
(202)\end{array}$ & $\begin{array}{l}3.1 .17 \mathrm{E}-01 \\
-\end{array}$ & $(2.666-02)$ & $(4.24-02)$ & (2.16-0-2) & $\begin{array}{l}\mid 3.17 \mathrm{E}-01] \\
-\end{array}$ & $(1.96-1-22)$ & (- & $\begin{array}{l}(4.922 \mathrm{E}-202) \\
(4)\end{array}$ & $\begin{array}{l}3.1 .1 \mathrm{E}-01 \\
-\end{array}$ & (3.930-02) & $(1.088-0202)$ & $(4.010-1-22)$ & 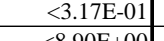 & $(3.84-8-03)]$ & $(4.19 \mathrm{E}-03)]$ \\
\hline $\mathrm{Sr}$ & $\mathrm{mm}$ & $\frac{1.41 \mathrm{E}-03)}{()^{2}}$ & $\mid 142-103)$ & & & $(141 \mathrm{E}-0.33$ & & $(1,0-0-03)$ & $(1313-03)$ & $(1414-03)$ & & & & $(1,33 E-03)$ & 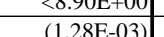 & & 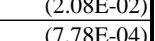 \\
\hline & $\mathrm{mM}$ & {$\left[\begin{array}{l}(2.32 \mathrm{E}-04) \\
\end{array}\right.$} & $<5.22 \mathrm{E}-22$ & $(5.78 \mathrm{E}-04)$ & $(3.33 \mathrm{E}-04)$ & $(2.32 \mathrm{E}-04)$ & $<5.22 \mathrm{E}-22$ & $<5.22 \mathrm{E}-022$ & $<5.22 \mathrm{E}-022$ & $<5.22 \mathrm{E}-02$ & $<5.22 \mathrm{E}-02$ & $<5.22 \mathrm{E}-022$ & $<5.22 \mathrm{E}-02 \mid$ & $(1.55 \mathrm{E}-03)$ & (5.99E-04) & $<5.22 \mathrm{E}-03$ & $(1.15 E-04)$ \\
\hline & $\mathrm{mM}$ & $\left(\frac{1.12 \mathrm{E}-02)]}{4}\right.$ & $(6.50 \mathrm{E}-03)]$ & $(7.18 \mathrm{E}-04) \mid$ & $<6.12 \mathrm{E}-02$ & $\frac{(1.12 \mathrm{E}-02)}{0}$ & $(6.50 \mathrm{E}-03)$ & $(5.86 \mathrm{E}-03)$ & $(3.11 \mathrm{E}-03)$ & $<6.12 \mathrm{E}-22$ & $(2.67 \mathrm{E}-03)$ & $(1.01 \mathrm{E}-02)$ & $(3.91 \mathrm{E}-03)$ & $(2.30 \mathrm{E}-03)$ & 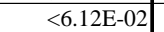 & & \\
\hline & $\mathrm{mM}$ & $<2.45 \mathrm{E}-011$ & $<2.45 \mathrm{E}-01]$ & $<2.45 \mathrm{E}-01$ & $<2.45 \mathrm{E}-01$ & $<2.45 \mathrm{E}-01$ & $<2.45 \mathrm{E}-01\}$ & $<2.45 \mathrm{E}-01]$ & $<2.45 \mathrm{E}-01]$ & $<2.45 \mathrm{E}-01]$ & $<2.45 E-01$ & $<2.45 \mathrm{E}-01]$ & $<2.45 \mathrm{E}-01]$ & $<2.45 \mathrm{E}-01$ & $<2.45 E-01$ & $<4.91 \mathrm{E}-03$ & $<4.91 \mathrm{E}-03$ \\
\hline$\frac{2 \pi}{7 r}$ & $\min 1$ & 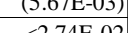 & (1.1.14-035) & 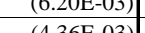 & 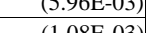 & 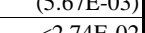 & 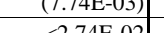 & 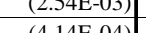 & 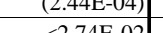 & 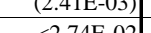 & 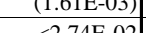 & 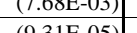 & & & 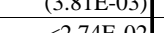 & & \\
\hline & & & & & & $2 ., 4 \mathrm{E}-02$ & $2 ., 4 \mathrm{E}=04$ & $(4,14 t-044)$ & $2 ., 14 \mathrm{E}-02$ & $2 ., 14 \mathrm{E}-04$ & $2 ., 4 \mathrm{E}-04$ & $(9.51 \mathrm{E}-02)$ & $2 ., 4 \mathrm{E}=04$ & $(3.45 \mathrm{E}-\mathrm{T} 4)$ & $2 ., 4 \mathrm{E}-02$ & $1.57 \mathrm{E}-04$ & $(2.90 \mathrm{E}-04)$ \\
\hline Anions & & & & & & & & & & & & & & & & & \\
\hline $\mathrm{NO}_{2}^{2}$ as $\mathrm{NO}_{2}-2$ & $\mathrm{mM}$ & $<9.80 \mathrm{E}-02$ & $<9.80 \mathrm{E}-22$ & $<9.80 \mathrm{E}-22$ & $<9.80 \mathrm{E}-02$ & $<9.80 \mathrm{E}-02$ & $<9.80 \mathrm{E}-02$ & $<9.80 \mathrm{E}-22$ & $<9.80 \mathrm{E}-22$ & $<9.80 \mathrm{E}-22$ & $<9.80 \mathrm{E}-22$ & $<9.80 \mathrm{E}-22$ & $<9.80 \mathrm{E}-22$ & $<9.80 \mathrm{E}-02$ & $<9.80 \mathrm{E}-22$ & $<9.80 \mathrm{E}-02$ & $<9.80 \mathrm{E}-02$ \\
\hline $\mathrm{NO}_{3}$ as $\mathrm{NO}_{3}-$ & $\mathrm{mM}$ & $<6.98 \mathrm{E}-02$ & $<6.98 \mathrm{E}-02$ & $<6.98 \mathrm{E}-02$ & $<6.98 \mathrm{E}-02$ & $<6.98 \mathrm{E}-02$ & $<6.98 \mathrm{E}-22$ & $<6.98 \mathrm{E}-22$ & $<6.98 \mathrm{E}-22$ & $<6.98 \mathrm{E}-22$ & $<6.98 \mathrm{E}-02$ & $<6.98 \mathrm{E}-22$ & $<6.98 \mathrm{E}-22$ & $<6.98 \mathrm{E}-02$ & $<6.98 \mathrm{E}-22$ & $<6.98 \mathrm{E}-22$ & $<6.98 \mathrm{E}-02$ \\
\hline $\mathrm{CO}_{3}^{2-}$ & $\mathrm{mM}$ & $<8.33 \mathrm{E}+00$ & $<8.33 \mathrm{E}+00 \mid$ & $<8.33 \mathrm{E}+00 \mid$ & $<8.33 \mathrm{E}+00$ & $<8.33 \mathrm{E}+00$ & $<8.33 \mathrm{E}+00 \mid$ & $<8.33 \mathrm{E}+00 \mid$ & $<8.33 \mathrm{E}+00 \mid$ & $<8.33 \mathrm{E}+00 \mid$ & $<8.33 \mathrm{E}+00$ & $<8.33 \mathrm{E}+00 \mid$ & $<8.33 \mathrm{E}+00 \mid$ & $<8.33 \mathrm{E}+00$ & $<8.33 \mathrm{E}+00 \mid$ & $<8.33 \mathrm{E}+00 \mid$ & $<8.33 \mathrm{E}+00$ \\
\hline $\mathrm{SO}_{4}{ }^{2} 7$ & $\mathrm{mM}$ & $<4.26 \mathrm{E}-02$ & $<4.26 \mathrm{E}-02$ & $<4.26 \mathrm{E}-02$ & 1.72E-01 & $<4.26 \mathrm{E}-02$ & $<4.26 \mathrm{E}-02 \mid$ & $<4.26 \mathrm{E}-02$ & $<4.26 \mathrm{E}-02 \mid$ & $<4.26 \mathrm{E}-02$ & $<4.26 \mathrm{E}-02$ & $<4.26 \mathrm{E}-02$ & $<4.26 \mathrm{E}-02$ & $<4.26 \mathrm{E}-02$ & $<4.26 \mathrm{E}-2 \mid$ & $<4.26 \mathrm{E}-02$ & $<4.26 \mathrm{E}-02$ \\
\hline $\mathrm{PO}^{3}=\mathrm{alO}_{4}^{3}$ & $\mathrm{mM}$ & $<5.32 \mathrm{E}-02$ & $<5.32 \mathrm{E}-02$ & $<5.32 \mathrm{E}-02$ & $<5.32 \mathrm{E}-02$ & $<5.32 \mathrm{E}-02$ & $<5.32 \mathrm{E}-02$ & $<5.32 \mathrm{E}-02$ & $<5.32 \mathrm{E}-02$ & $<5.32 \mathrm{E}-02$ & $<5.32 \mathrm{E}-02$ & $<5.32 \mathrm{E}-02$ & $<5.32 \mathrm{E}-02$ & $<5.32 \mathrm{E}-02$ & $<5.32 \mathrm{E}-02$ & $<5.32 \mathrm{E}-02$ & $<5.32 \mathrm{E}-02$ \\
\hline & $\mathrm{mM}$ & $<6.66 \mathrm{E}-02$ & $<6.66 \mathrm{E}-022$ & $<6.65 \mathrm{E}-022$ & $<6.65 \mathrm{E}-02$ & $\begin{array}{l}<6.66 \mathrm{E}-02 \\
\end{array}$ & $<6.66 \mathrm{E}-022$ & $<6.66 \mathrm{E}-02$ & $<6.66 \mathrm{E}-02$ & $\begin{array}{r}<6.66 \mathrm{E}-02 \\
2\end{array}$ & $\begin{array}{r}<6.66 \mathrm{E}-0 \\
0\end{array}$ & $<6.66 \mathrm{E}-022$ & $\langle 6.66 \mathrm{E}-22$ & $<6.66 \mathrm{E}$ & $\langle 6.66 \mathrm{E}-22$ & $<6.66 \mathrm{E}-022$ & $<6.66$ \\
\hline $\begin{array}{c}\mathrm{F} \\
\text { Oxalate }\end{array}$ & $\frac{\mathrm{mM}}{\mathrm{mM}}$ & $\begin{array}{l}<6.162-02 \\
<3.92-02 \\
<02\end{array}$ & $\begin{array}{ll}<6.196-02 \\
<3.22 \mathrm{E}-02\end{array}$ & $\begin{array}{l}<6.16 \mathrm{E}-02 \\
<3.22 \mathrm{E}-02 \\
<2\end{array}$ & 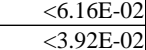 & 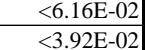 & 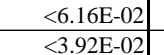 & $\begin{aligned}<6.16 \mathrm{E}-02 \\
<3.29 \mathrm{E}-02\end{aligned}$ & 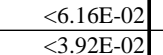 & $\begin{aligned}<6.16 \mathrm{E}-02 \\
<392 \mathrm{E}-02 \\
<1\end{aligned}$ & $\begin{array}{l}<6.16 \mathrm{E}-02 \\
<-392 \mathrm{E}-02\end{array}$ & 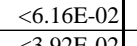 & 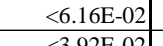 & $\begin{array}{l}<6.16 \mathrm{E}-02 \\
<-30250\end{array}$ & 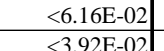 & $\begin{array}{l}<6.16 \mathrm{E}-02 \\
-3=020\end{array}$ & 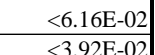 \\
\hline
\end{tabular}


Table F.4. Tank Chem $405 \mathrm{CaCO}_{3}$

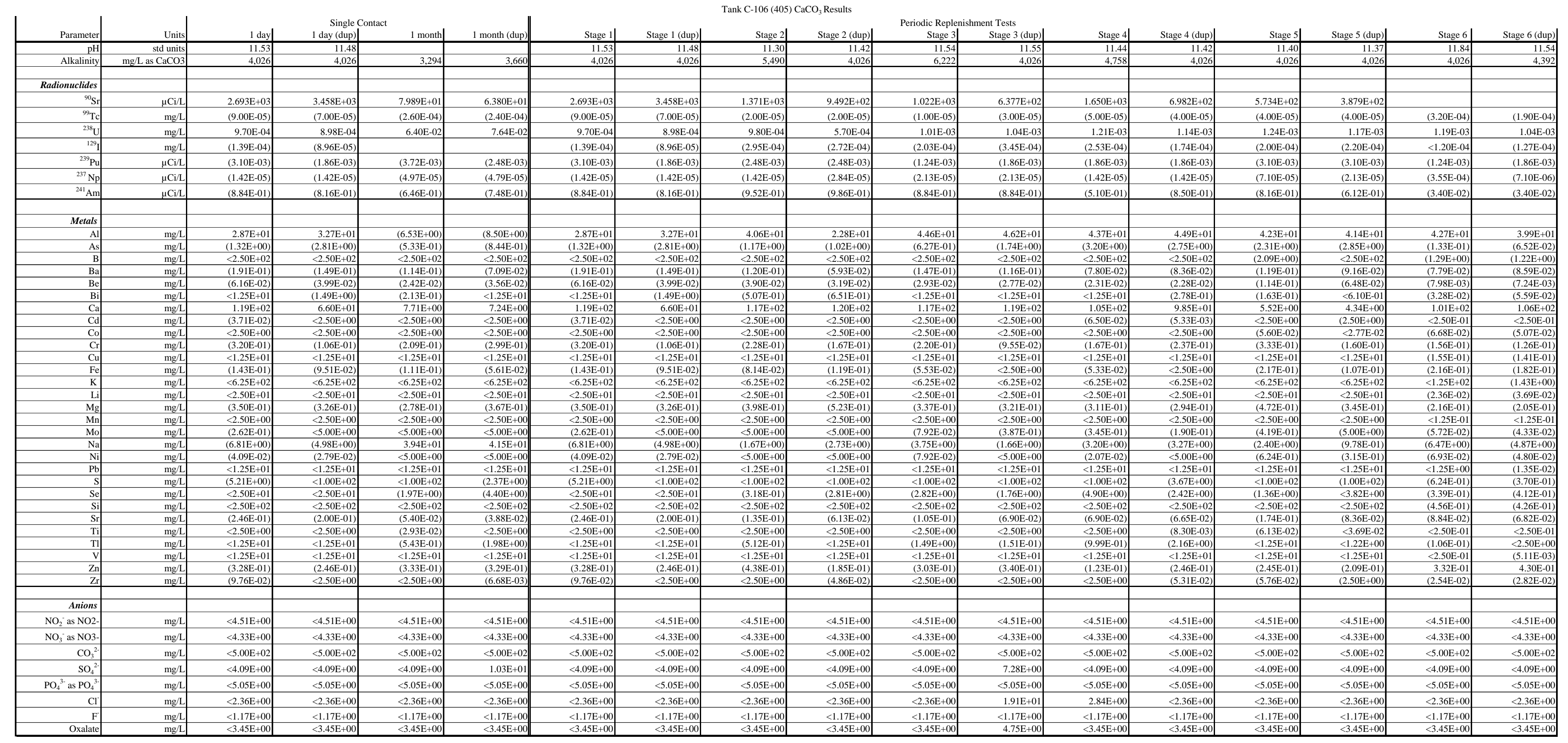


Table F.4. (contd)

\begin{tabular}{|c|c|c|c|c|c|c|c|c|c|c|c|c|c|c|c|c|c|}
\hline \multicolumn{18}{|c|}{ Tank C-106 (405) $\mathrm{CaCO}_{3}$ Results } \\
\hline Parameter & Units & 1 day & $\begin{array}{r}\text { Single C } \\
1 \text { day (dup)| }\end{array}$ & 1 month] & 1 month (dup) & Stage 1 & Stage 1 (dup) & Stage 2 & Stage 2 (dup) & 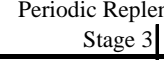 & $\begin{array}{l}\text { nent Tests } \\
\text { Stage 3(dup) } \\
\end{array}$ & Stage 4 & Stage 4 (dup) & Stage 5 & Stage 5 (dup) & Stage 6 | & Stage 6 (dup) \\
\hline $\begin{array}{l}\text { pH } \\
\text { Alkalinity } \\
\end{array}$ & $\begin{array}{l}\text { std units } \\
\mathrm{mM} \text { as } \mathrm{CaCO} 3\end{array}$ & 40.2 & 40.2 & $32.9]$ & 36.6 & 40.2 & 40.2 & 54.9 & 40.2. & 62.2 & 40.2 & 47.5 & 40.2 & 40.2 & $\mid 40.2$ & 40.2 & 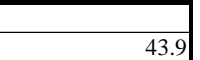 \\
\hline Radionuclides & & & & & & & & & & & & & & & & & \\
\hline 90sr & $\mathrm{mM}$ & $2.137 \mathrm{E}-04$ & $2.744 E-04$ & & & $2.137 E-04$ & $2.744 \mathrm{E}-4 \mid$ & $1.088 \mathrm{E}-04$ & $7.534 \mathrm{E}-05$ & $8.109 \mathrm{E}-05$ & $5.061 \mathrm{E}-05$ & $\mid 1.309 \mathrm{E}-04$ & 5.541E-05 & 4.551E-05 & $3.078 \mathrm{E}-05$ & & \\
\hline${ }^{99} \mathrm{TC}$ & $\mathrm{mM}$ & $(9.09 \mathrm{E}-07)$ & $(7.07 \mathrm{E}-07)$ & $(2.63 \mathrm{E}-06)$ & $(2.42 \mathrm{E}-06)$ & $(9.09 \mathrm{E}-07)$ & $(7.07 \mathrm{E}-07)$ & $(2.02 E-07)$ & $(2.02 E-07)$ & $(1.01 \mathrm{E}-07)$ & $(3.03 \mathrm{E}-07)$ & $(5.05 E-07)$ & $(4.048-07)$ & $(4.048-07)$ & $(4.04 E-07)$ & $(3.23 \mathrm{E}-06)$ & $(1.92 \mathrm{E}-06)$ \\
\hline & $\mathrm{mm}$ & $4.08 E-06$ & $(3.77 \mathrm{E}-06)$ & $2.69 \mathrm{E}-04$ & $3.21 E-04$ & $\begin{array}{r}4.088-06 \\
\end{array}$ & $(3.77 \mathrm{E}-06)$ & $4.12 \mathrm{E}-06$ & $2.39 \mathrm{E}-06$ & $4.25 \mathrm{E}-06$ & $(4.37 \mathrm{E}-06)$ & $5.08 E-06$ & $\begin{array}{l}4.79 E-066 \\
\end{array}$ & $(5.21 \mathrm{E}-66)$ & $4.92 E-06$ & $5.00 \mathrm{E}-06$ & $4.37 \mathrm{E}-06$ \\
\hline & $\mathrm{mM}$ & $(1.08 \mathrm{E}-06)$ & $(6.95 E-07) \mid$ & $0.00 \mathrm{E}+00$ & $0.00 \mathrm{E}+00$ & $(1.08 \mathrm{E}-06)$ & $(6.95 \mathrm{E}-077)$ & & & & & & & & & $(9.33 \mathrm{E}-07)$ & \\
\hline${ }^{239} \mathrm{Pu}$ & $\mathrm{mM}$ & $(2.09 \mathrm{E}-06)$ & $(1.26 \mathrm{E}-06)$ & $(2.51 \mathrm{E}-06)$ & $(1.67 \overline{-}-06)$ & $(2.09 \mathrm{E}-06)$ & $(1.26 \mathrm{E}-06)$ & $(1.67 \mathrm{E}-06)$ & $(1.67 \mathrm{E}-06)$ & $(8.37 \mathrm{E}-07)$ & $(1.26 \mathrm{E}-06)$ & $(1.26 \mathrm{E}-06)$ & $(1.26 \mathrm{E}-06)$ & $(2.09 \mathrm{E}-06)$ & $(2.09 \mathrm{E}-06)$ & $(8.37 \mathrm{E}-07)$ & $(1.26 \mathrm{E}-06)$ \\
\hline & $\mathrm{mm}$ & $(8.44 \mathrm{E}-08)]$ & $(8.44 \mathrm{E}-08)$ & $(2.95 \mathrm{E}-077)$ & $(2.85 E-77)$ & $(8.44 \mathrm{E}-08)$ & $(8.44 \mathrm{E}-08)]$ & $(8.44 \mathrm{E}-08)]$ & $(1.69 \mathrm{E}-07)$ & $(1.27 \mathrm{E}-07)$ & $(1.27 \mathrm{E}-07)]$ & $(8.44 \mathrm{E}-08)$ & $(8.44 \mathrm{E}-08)$ & $(4.22 \mathrm{E}-07)$ & $(1.27 \mathrm{E}-077)$ & $(2.11 \mathrm{E}-06)$ & $(4.22 \mathrm{E}-08)$ \\
\hline . ${ }^{241 \mathrm{Am}}$ & $\mathrm{mm}$ & $(1.08 E-06)$ & $(9.96 \mathrm{E}-07)$ & $(7.88 \mathrm{E}-077)$ & $(9.13 \mathrm{E}-07)$ & $(1.08 \mathrm{E}-06)$ & $(9.96 \mathrm{E}-077)$ & $(1.16 \mathrm{E}-06)$ & $(1.20 \mathrm{E}-06)$ & $(1.08 \mathrm{E}-06)$ & $(1.08 E-06)$ & $(6.22 \mathrm{E}-07)$ & $(1.048-06)$ & (9.96E-07) & $(7.47 \mathrm{E}-07)$ & $<4.15 \mathrm{E}-08$ & $<4.15 \mathrm{E}-08$ \\
\hline & & & & & & & & & & & & & & & & & \\
\hline \begin{tabular}{rl|} 
Metals & Al \\
\end{tabular} & & & & $(2.42 \mathrm{E}-01)]$ & & & $1.21 E+00 \mid$ & & & & & & $1.66 \mathrm{E}+00$ & & & $158 \mathrm{E}+00 \mathrm{l}$ & \\
\hline & $\mathrm{mM}$ & $(1.76 \mathrm{E}-02)$ & $(3.75 \mathrm{E}-02)$ & $(7.12 \mathrm{E}-03)$ & $41.13 \mathrm{E}-02$ & $(1.76 \mathrm{E}-02)$ & $(3.75 \mathrm{E}-02)$ & $\frac{1.56 \mathrm{E}-02)}{(1.52)}$ & $<1.36 \mathrm{E}-02$ & $(8.37 \mathrm{E}-03)$ & $(2.32 \mathrm{E}-02)$ & $\frac{1.427 \mathrm{E}-02)}{(4)}$ & $\frac{1.36 \mathrm{E}-02)}{(3.67)}$ & $\frac{3.08 \mathrm{E}-02)}{(3.02)}$ & $(3.80 \mathrm{E}-02)$ & $(1.77 \mathrm{E}-03)$ & $\frac{1.46 \mathrm{E}-04}{(8.70 \mathrm{E}-04)}$ \\
\hline & $\mathrm{mM}$ & $2.31 \mathrm{E}+01$ & $<2.31 \mathrm{E}+01]$ & $\frac{<2.31 \mathrm{E}+01}{2.020}$ & $<2.31 \mathrm{E}+01$. & $<2.31 \mathrm{E}+01$ & $22.31 E+01$ & $\frac{22.31 E+01}{2.3201}$ & $22.31 \mathrm{E}+01$ & $<2.31 \mathrm{E}+01$ & $22.31 E+01$ & $<2.31 \mathrm{E}+01$ & $\langle 2.31 \mathrm{E}+1|$ & $(1.93 \mathrm{E}-01)$ & $\langle 2.31 E+01|$ & $\mid(1.19 \mathrm{E}-01)$ & $(1.13 \mathrm{E}-012)$ \\
\hline $\mathrm{Ba}$ & $\mathrm{mM}$ & (1.39E-03)| & 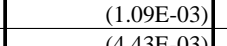 & (8.33E-04) & $\frac{(5.16 E-04)}{(205-2023)}$ & $\begin{array}{l}(1.39 \mathrm{E}-03) \mid \\
(10202)\end{array}$ & 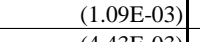 & 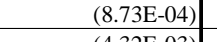 & 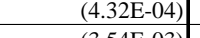 & $\frac{(1.07 E-03)}{(2.25-023)}$ & $(8.45 E-04)$ & $(5.68 \mathrm{E}-04)]$ & $\frac{(.088-040)}{(6.025)}$ & 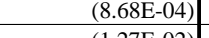 & 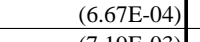 & 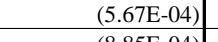 & 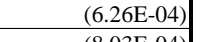 \\
\hline & $\mathrm{mM}$ & (6.83E-03)] & 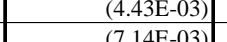 & 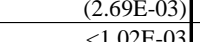 & $\begin{array}{l}(3.95 E-033) \mid \\
<5985-02\end{array}$ & (6.83E-03) $<589 \mathrm{E}-2]$ & (4.43E-03] & 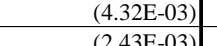 & $(3.54 \mathrm{E}-03)$ & $\begin{array}{l}(3.25 \mathrm{E}-03) \\
\langle 509 \mathrm{E}-02\end{array}$ & 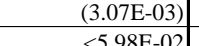 & (2.57--03) & $(2.53 \mathrm{E}-03)$ & $\frac{(1.27 \mathrm{E}-02)}{\langle 78 \mathrm{E}-04} \mid$ & $(7.19 \mathrm{E}-03) \mid$ & 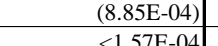 & $\left(8.03 \mathrm{E}_{-04}-4\right)$ \\
\hline & $\frac{\mathrm{mm}}{\mathrm{mM}}$ & $\begin{array}{l}2.386 E E-02 \\
2.96 E+00\end{array}$ & 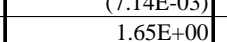 & 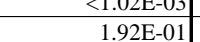 & 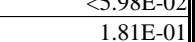 & $\begin{array}{l}2.596 \mathrm{E}-02 \\
2.96 \mathrm{E}+00 \mid\end{array}$ & 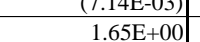 & 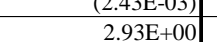 & 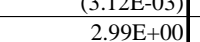 & $\begin{array}{l}2.9 .96-02 \\
2.91 E+00 \mid\end{array}$ & $\begin{array}{l}2.536 E E-04 \\
2.98+00\end{array}$ & $\begin{array}{l}2.586 \mathrm{E}-02 \\
2.62 \mathrm{E}+00 \mid\end{array}$ & 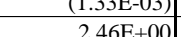 & 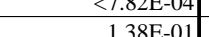 & 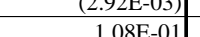 & 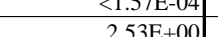 & 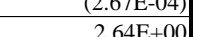 \\
\hline $\mathrm{Cd}$ & $\mathrm{mM}$ & $<3.30 \mathrm{E}-04$ & $<2.22 \mathrm{E}-02$ & $<2.22 \mathrm{E}-02$ & $\frac{1.02 \mathrm{E}-02)}{(2.22)}$ & $<3.30 \mathrm{E}-04$ & $<2.22 \mathrm{E}-02$ & (2.22E-02) & $<2.22 \mathrm{E}-02$ & $<2.22 \mathrm{E}-02$ & 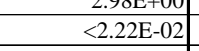 & $<<.78 \mathrm{E}-04$ & $<4.74 \mathrm{E}-05$ & $\frac{1.00 \mathrm{E}-01}{(2.22 \mathrm{E}-22)}$ & $\frac{1.0 .0 \mathrm{E}-02)}{(2.22 \mathrm{E}-2)}$ & $\mid<2.22 \mathrm{E}-03$ & $\begin{array}{l}2.04 \mathrm{E}-0 \mid \\
<2.22 \mathrm{E}-03 \\
\end{array}$ \\
\hline & $\mathrm{mm}$ & $\langle 4.24 \mathrm{E}-02|$ & $\langle 4.24 \mathrm{E}-22|$ & $<4.248-02 \mid$ & $<4.24 \mathrm{E}-22$ & $\langle 4.248-02|$ & $\langle 4.24 E-02|$ & $\begin{array}{l}<4.24 \mathrm{E}-02 \\
\end{array}$ & 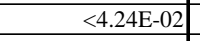 & $(4.24 \mathrm{E}-22)$ & $<4.24 E-02 \mid$ & $\langle 4.248-02|$ & $\langle 4.248--22$ & $\mid(9.51 \mathrm{E}-04)$ & $<4,708-04$ & $(1.13 \mathrm{E}-03)$ & (8.59פ- -44) \\
\hline & $\mathrm{mM}$ & 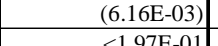 & $(2.044-03)]$ & 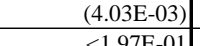 & $\frac{(5.74 E-03)}{5107-01}$ & $(6.16-03)]$ & 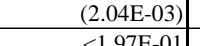 & $(4.38 \mathrm{E}-03) \mid$ & $(3.22 \mathrm{E}-03) \mid$ & 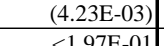 & $(1.84 \mathrm{E}-03)$ & $\frac{(3.22 \mathrm{E}-03)}{-192 \mathrm{~F}-01}$ & $\begin{array}{c}(4.56 \mathrm{E}-03) \\
1.97 \mathrm{~F}-01\end{array}$ & $\frac{(6.41 \mathrm{E}-03)}{-197 \mathrm{C}-01}$ & 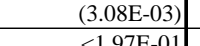 & 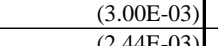 & $(2.411-03)$ \\
\hline & $\frac{\mathrm{mm}}{\mathrm{mM}}$ & 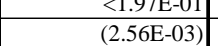 & (1.79E-01 & $\begin{array}{l}\text { (1.9.9EE-01 } \\
(1.99-03)\end{array}$ & $\mid$ & $\begin{array}{l}1.9 .96-12-01 \\
(2.56-03)\end{array}$ & (1.7.9EE-01| & $\begin{array}{l}\mid 1.9 .9 E-01 \\
<1.46 E-03\end{array}$ & $\begin{array}{l}(1.9 .9 E-01 \\
(2.14 E-03)\end{array}$ & $\begin{array}{l}(1.9 .96-01 \\
(9.90-04)\end{array}$ & $\begin{array}{l}(1.9 .98 E-14 \\
(4.48-02)\end{array}$ & 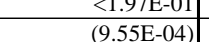 & $\begin{array}{l}(1.96 \mathrm{E}-01 \\
(4.48 \mathrm{E}-02)\end{array}$ & $\begin{array}{l}\mid 1.99 \mathrm{E}-01 \\
(3.89 \mathrm{E}-03\end{array}$ & $\begin{array}{l}(1.99-1 E-01 \\
(1.92 E-03)\end{array}$ & $\begin{array}{l}(2.344-E-3) \\
(3.86-03)\end{array}$ & $\left(\frac{2.225 \mathrm{E}-3)}{(3.25-3)}\right]$ \\
\hline & $\mathrm{mM}$ & (1..60E+01 & |c1.60E & $<1.60 \mathrm{E}+01$ & $\langle 1.60 \mathrm{E}+01]$ & $\mid$ & $\mid$ & 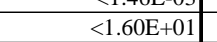 & $<1.60 \mathrm{E}+01$ & $\langle<1.60 \mathrm{E}+01\rangle$ & 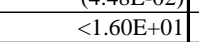 & $\mid$ & 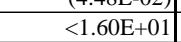 & (1.60E+01 & $<1.60 \mathrm{E}+01$ & $(3.20 \mathrm{E}+00)$ & 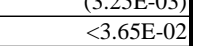 \\
\hline $\mathrm{Li}$ & $\mathrm{mM}$ & $<3.60 \mathrm{E}+00$ & $<3.60 \mathrm{E}+00$ & $<3.60 \mathrm{E}+00$ & $<3.60 \mathrm{E}+00$ & $<3.60 \mathrm{E}+00$ & $\langle 3.60 \mathrm{E}+00$ & $\angle 3.60 \mathrm{E}+00$ & $<3.60 \mathrm{E}+00$ & $<3.60 \mathrm{E}+00$ & $<3.60 \mathrm{E}+00$ & $<3.60 \mathrm{E}+00$ & $<3.60 \mathrm{E}+00$ & $<3.60 \mathrm{E}+00$ & $<3.60 \mathrm{E}+00$ & $(3.39 \mathrm{E}-03)$ & (5.311E-03) \\
\hline & $\mathrm{mm}$ & (1.44E-02)] & $(1.34 \mathrm{E}-02)]$ & (1.115-02) & $(1.51 \mathrm{E}-02)]$ & $(1.44 \mathrm{E}-22)$ & {$[(1.34 \mathrm{E}-02)]$} & $(1.64 \mathrm{E}-02)$ & $(2.15 \mathrm{E}-02)$ & $(1.39 \mathrm{E}-22)]$ & $(1.32 \mathrm{E}-02)]$ & $(1.28 \mathrm{E}-02)$ & $(1.21 \mathrm{E}-22)$ & $(1.94 \mathrm{E}-02)$ & $(1.42 \mathrm{E}-02)]$ & $(8.87 \mathrm{E}-03)$ & $(8.45 \mathrm{E}-03)$ \\
\hline & $\frac{\mathrm{mM}}{\mathrm{mM}}$ & 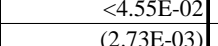 & 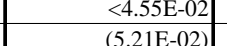 & 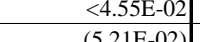 & 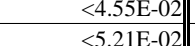 & 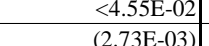 & $\begin{array}{l}4.55 E-02 \mid \\
(5,251 \mid-02)\end{array}$ & $\begin{array}{l}<4.55 \mathrm{E}-02 \\
<5.21 \mathrm{E}-02\end{array}$ & $\begin{array}{l}<4.55 E-02 \\
<5.21 E-02 \mid\end{array}$ & $\begin{array}{l}4.55 \mathrm{E}-02 \\
(826 \mathrm{E}-0.4)\end{array}$ & $\begin{array}{c}<4.55 E-02 \\
<400 \mathrm{E}-02]\end{array}$ & $\begin{array}{l}<4.55 E-02 \\
\mid 2605-023)\end{array}$ & 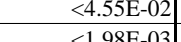 & $(4.55-25)$ & 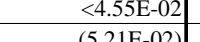 & $(2.28 \mathrm{E}-03)$ & $\begin{array}{r}2.28 \mathrm{E}-03 \\
(4151 \mathrm{E}-4)\end{array}$ \\
\hline & $\frac{\mathrm{mm}}{\mathrm{mM}}$ & $\frac{(2.75-5-3)}{(2.96-01)}$ & $\frac{(2.217-252)}{(2.17 E-01)}$ & $\frac{(5.211-12-2)}{1.71 E+00}$ & 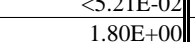 & 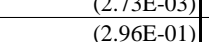 & 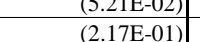 & (5.28EE-02 & 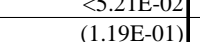 & $\frac{(8.626-25-4)}{(1.63-01)}$ & 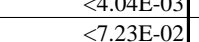 & 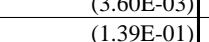 & 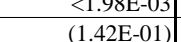 & $\frac{(4.3 / 5-\mathrm{E}-03)}{(1.04-01)}$ & $\frac{(5.14-12-2)}{(4.26 E-02)}$ & $\frac{(.596 \mathrm{E}-44)}{(2.81-01)}$ & $\frac{(4.51 E-404)}{(2.12-01)}$ \\
\hline & $\begin{array}{ll}\mathrm{mM} \\
\end{array}$ & $\mid$ & $(4.76 \mathrm{E}-44)$ & $(8.52 \mathrm{E}-02)$ & $<8.52 \mathrm{E}-02$ & $\mid$ & $\left(\frac{2.17 .76-04)}{(4.76)}\right.$ & $<8.52 \mathrm{E}-02$ & $48.52 \mathrm{E}-02$ & $\frac{1.35 \mathrm{E}}{(1.35)}$ & $(8.52 \mathrm{E}-02)$ & $<3.52 \mathrm{E}-04$ & $<8.52 \mathrm{E}-02$ & $(1.06 \mathrm{E}-02)$ & $(5.37 \mathrm{E}-03)$ & $(1.18 \mathrm{E}-03)$ & (8.18E-04) \\
\hline $\mathrm{Pb}^{\mathrm{pb}}$ & $\mathrm{mM}$ & $<6.03 \mathrm{E}-02$ & $<6.03 \mathrm{E}-22$ & $<6.03 \mathrm{E}-02$ & $<6.03 \mathrm{E}-22$ & $<6.03 \mathrm{E}-22$ & $<6.03 \mathrm{E}-02$ & $<6.03 \mathrm{E}-22$ & $<6.03 \mathrm{E}-22$ & $<6.03 \mathrm{E}-22$ & $<6.03 \mathrm{E}-22$ & $<6.03 \mathrm{E}-22$ & $<6.03 \mathrm{E}-02$ & $<6.03 \mathrm{E}-22$ & $<6.038-02$ & $<6.03 \mathrm{E}-03$ & $(6.50 \mathrm{E}-05)$ \\
\hline & $\mathrm{mM}$ & $<1.62 \mathrm{E}-01$ & $(3.12 \mathrm{E}+00)$ & $\langle 3.12 \mathrm{E}+00$ & $<7.38 \mathrm{E}-02]$ & $<1.62 \mathrm{E}-01$ & $(3.12 \mathrm{E}+00)]$ & $(3.12 \mathrm{E}+00)]$ & $\langle 3.12 \mathrm{E}+00|$ & $\langle 3.12 \mathrm{E}+00$ & $\langle 3.12 \mathrm{E}+00|$ & $\langle 3.12 \mathrm{E}+00|$ & $(1.14 \mathrm{E}-01)$ & $\langle 3.12 \mathrm{E}+00|$ & $(3.12 \mathrm{E}+00)]$ & $(1.94 \mathrm{E}-022)]$ & $<1.15 \mathrm{E}-02$ \\
\hline & $\mathrm{mM}$ & (3.176-1) & 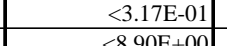 & $(2.49 \mathrm{E}-22)$ & $(5.58 \mathrm{E}-22)$ & $(3.17 \mathrm{E}-01)$ & 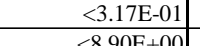 & 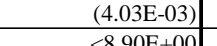 & (3.56E-22) & (3.57--22) & $\begin{array}{l}<2.23 \mathrm{E}-02 \\
<<80 \mathrm{~B}+02\end{array}$ & $(6.20 \mathrm{E}-22)$ & $(3.06 \mathrm{E}-02)$ & $(1.72 \mathrm{E}-22)$ & 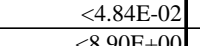 & $(4.29 \mathrm{E}-03)]$ & $(5.21 E-03)$ \\
\hline & $\frac{\mathrm{mM}}{\mathrm{mM}}$ & & & & 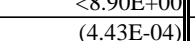 & 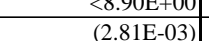 & 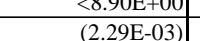 & 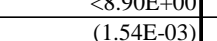 & 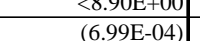 & & & 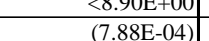 & & 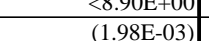 & 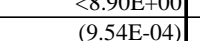 & $\frac{(1.625-202)}{(1.101-03)}$ & $\frac{(1.525 \mathrm{E}-22)}{(7.790-04)}$ \\
\hline & $\mathrm{mM}$ & (5.22E-02) & $\langle 5.22 \mathrm{E}-02$ & (6.1615-04) & $(5.22 \mathrm{E}-02)$ & $(5.22 \mathrm{E}-02)$ & $<5.22 \mathrm{E}-02$ & $<5.22 \mathrm{E}-02$ & $<5.22 \mathrm{E}-02$ & $\frac{(1.120 \mathrm{E}-0.03)}{<5.22 \mathrm{E}-02}$ & 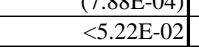 & $<5.22 \mathrm{E}-02$ & $<1.73 \mathrm{E}-04$ & $(1.28 \mathrm{E}-03)$ & & $<5.22 \mathrm{E}-03$ & (5.22E-04) \\
\hline & $\mathrm{mM}$ & $(6.12 \mathrm{E}-02)$ & $(6.12 \mathrm{E}-02)$ & $(2.66 \mathrm{E}-03)$ & 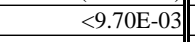 & $\mid$ & $(6.12 \mathrm{E}-02)$ & $(2.50 \mathrm{E}-03)$ & $\mid(6.12 \mathrm{E}-02)$ & $<7.30 \mathrm{E}-03$ & $(7.37 \mathrm{E}-04)$ & $(4.89 \mathrm{E}-03)$ & $(1.05 E-02)$ & $(6.12 \mathrm{E}-02)$ & $<5.97 \mathrm{E}-03$ & 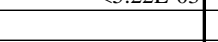 & 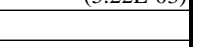 \\
\hline & $\mathrm{mM}$ & $<2.45 \mathrm{E}-01]$ & $<2.45 E-01]$ & $<2.45 \mathrm{E}-01$ & 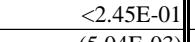 & $<2.45 E-01]$ & $<2,45 E-01]$ & $\begin{array}{l}<2.45 \mathrm{E}-01 \\
\mid\end{array}$ & $\langle 2.45 \mathrm{E}-01]$ & $<2.45 E-01$ & $<2.45 \mathrm{E}-01 \mid$ & $<2.45 \mathrm{E}-01]$ & $<2.45 \mathrm{E}-01]$ & $<2.45 \mathrm{E}-01$ & $<2.45 E-01 \mid$ & $<4.91 E-03 \mid$ & $<1.00 E-04$ \\
\hline$\frac{\mathrm{Zn}}{\mathrm{Zn}}$ & $\frac{\mathrm{mM}}{\mathrm{mM}}$ & (5.02E-03) & $\mid \begin{array}{c}\mid(3.76 \mathrm{E}-03) \\
<<.24 \mathrm{E}-0)\end{array}$ & $\frac{(5.10 \mathrm{E}-3)}{(2.74-02)}$ & $\frac{(5.048-0.03)}{(1,733-05}$ & 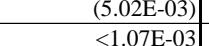 & 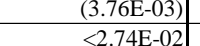 & (6.70E-03) & $\frac{(2.83-\mathrm{E}-3.3)}{\langle 553 \mathrm{E}-4|}$ & $\frac{(4.64 \mathrm{E}-0.3)}{<2.73 \mathrm{E}-02]}$ & (5.217-03) & $\frac{(1.88-8-3)-3)}{(2.74-02)}$ & $\frac{(3.78 \mathrm{E}-033)}{-558 \mathrm{E}-04}$ & (3.744-03)| & 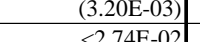 & 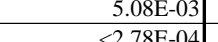 & $\frac{6.57 \mathrm{E}-03}{(0.09-04)}$ \\
\hline & & & & & & & & & & & & & & & & & \\
\hline \begin{tabular}{|c|} 
Anions \\
\end{tabular} & & & & & & & & & & & & & & & & & \\
\hline $\mathrm{NO}_{2}^{2}$ as $\mathrm{NO}_{2}$ & $\mathrm{~mm}$ & $<9.80 \mathrm{E}-22$ & $<9.80 \mathrm{E}-02 \mid$ & $<9.80 \mathrm{E}-22$ & $<9.80 \mathrm{E}-22$ & $<9.80 \mathrm{E}-22$ & $<9.80 \mathrm{E}-02$ & $\langle 9.80 \mathrm{E}-02$ & $<9.80 \mathrm{E}-02$ & $<9.80 \mathrm{E}-22$ & $<9.80 \mathrm{E}-02$ & $<9.80 \mathrm{E}-22$ & $<9.80 \mathrm{E}-22$ & $<9.80 \mathrm{E}-22$ & $<9.80 \mathrm{E}-02$ & $<9.80 \mathrm{E}-22$ & $<9.80 \mathrm{E}-0$. \\
\hline $\mathrm{NO}_{3}$ as $\mathrm{NO}_{3}-$ & $\mathrm{mM}$ & & & & & $<6.98 \mathrm{E}-22$ & $<6.98$ & $<6.98 \mathrm{E}-22$ & & $<6.98 \mathrm{E}-22$ & $<6.98$ & $<6.98 \mathrm{E}-22$ & & $<6.98 \mathrm{E}$ & & $<6.98 \mathrm{E}-22$ & $<6.981$ \\
\hline $\mathrm{CO}_{3}^{2-}$ & $\mathrm{mM}$ & $<8.33 \mathrm{E}+00$ & $<8.33 \mathrm{E}+00 \mid$ & $<8.33 \mathrm{E}+00$ & $<8.33 \mathrm{E}+000$ & $\langle 8.33 \mathrm{E}+00|$ & $<8.33 \mathrm{E}+00 \mid$ & $<8.33 \mathrm{E}+00 \mid$ & $<8.33 \mathrm{E}+00 \mid$ & $<8.33 \mathrm{E}+00$ & $<8.33 \mathrm{E}+00 \mid$ & $<8.33 \mathrm{E}+00 \mid$ & $<8.33 \mathrm{E}+00$ & $<8.33 \mathrm{E}+00 \mid$ & $<8.33 \mathrm{E}+00 \mid$ & $\langle 8.33 \mathrm{E}+00|$ & $<8.33 \mathrm{E}-$ \\
\hline $\mathrm{SO}_{4}^{2-}$ & $\mathrm{mm}$ & $<4.26 \mathrm{E}-02$ & $<4.26 \mathrm{E}-22$ & $<4.26 \mathrm{E}-02$ & $\begin{array}{l}1.07 \mathrm{E}-01 \| \\
\|\end{array}$ & $<4.26 \mathrm{E}-02$ & $<4.26 \mathrm{E}-02 \mid$ & $<4.26 \mathrm{E}-02$ & $<4.26 \mathrm{E}-02 \mid$ & $<4.26 \mathrm{E}-22$ & $<7.58 \mathrm{E}-02$ & $<4.26 \mathrm{E}-22$ & $<4.26 \mathrm{E}-22$ & $<4.26 \mathrm{E}-02$ & $<4.26 \mathrm{E}-02$ & $<4.26 \mathrm{E}-02$ & $\langle 4.26 \mathrm{E}-02$ \\
\hline $\mathrm{PO}_{4}^{3}$ as $\mathrm{PO}_{4}^{3}$ & $\mathrm{mM}$ & 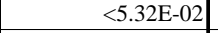 & $<5.32 \mathrm{E}-02$ & $<5.32 \mathrm{E}-02$ & $<5.32 \mathrm{E}-02$ & $<5.32 \mathrm{E}-02$ & $<5.32 \mathrm{E}-22$ & $<5.32 \mathrm{E}-02$ & $<5.32 \mathrm{E}-02 \mid$ & $<5.32 \mathrm{E}-02$ & $<5.32 \mathrm{E}-02$ & $<5.32 \mathrm{E}-02 \mid$ & $<5.32 \mathrm{E}-02$ & $<5.32 \mathrm{E}-02$ & $<5.32 \mathrm{E}-02$ & $<5.32 \mathrm{E}-22$ & $<5.32 \mathrm{E}-02$ \\
\hline & $\mathrm{mm}$ & $<6.66 \mathrm{E}-02$ & $<6.66 \mathrm{E}-02 \mid$ & $<6.65 \mathrm{c}-02$ & $<6.65 \mathrm{E}-02$ & $<6.66 \mathrm{E}-02 \mid$ & $<6.66 \mathrm{E}-02$ & $<6.66 \mathrm{E}-02 \mid$ & $<6.66 \mathrm{E}$ & $<6.66$ & $<5.38 \mathrm{E}-01$ & $<8.03 \mathrm{E}-02$ & $<6.66 \mathrm{E}-02$ & $<6.66$ & $<6.66 \mathrm{E}-02$ & $<6.66$ & \\
\hline \begin{tabular}{|c|}
$F$ \\
Oxalate
\end{tabular} & $\mathrm{mM}$ & $\begin{aligned}<6.16 \mathrm{E}-02 \\
<3.32 \mathrm{E}-2.22\end{aligned}$ & $\begin{array}{c}<6.16 \mathrm{E}-02 \\
<.325 \mathrm{E}-2.2\end{array}$ & $\begin{aligned}<6.16 \mathrm{E}-02 & <.32 \mathrm{E}-2.21\end{aligned}$ & $\begin{array}{r}<6.16 \mathrm{EE}-02 \\
<3.29 \mathrm{E}-02\end{array}$ & $\begin{aligned}<6.16 \mathrm{E}-02 \\
<<.32 \mathrm{E}-22\end{aligned}$ & 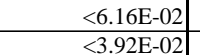 & $\begin{array}{c}<6.16 \mathrm{E}-02 \\
<<.32 \mathrm{E}-2.2\end{array}$ & $\begin{array}{r}<6.16 \mathrm{E}-02 \\
<3.92 \mathrm{E}-02\end{array}$ & $\begin{array}{r}<6.16 \mathrm{E}-02 \\
<3.92 \mathrm{E}-02\end{array}$ & $\begin{array}{l}<6.16 \mathrm{EE}-02 \\
<5.39 \mathrm{E}-2.21\end{array}$ & 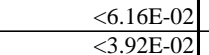 & $\begin{array}{r}6.16 \mathrm{E}-02 \\
\\
3.92 \mathrm{E}-02\end{array}$ & $\begin{aligned}<6.16 \mathrm{E}-02 \\
<3.32 \mathrm{E}-2.22\end{aligned}$ & $\begin{array}{l}<6.16 \mathrm{E}-02 \\
<3.32 \mathrm{E}-02\end{array}$ & $\begin{aligned}<6.16 \mathrm{E}-02 \\
<-3.32 \mathrm{E}-2.2\end{aligned}$ & $\begin{array}{r}<6.16 \mathrm{E}-02 \\
<3.92 \mathrm{E}-02\end{array}$ \\
\hline
\end{tabular}




\section{Distribution}

No. of

$\underline{\text { Copies }}$

\section{OFFSITE}

Steve Airhart

Freestone Environmental Services

1933 Jadwin Avenue

Richland, WA 99354

Dr. Harry Babad

2540 Cordoba Court

Richland, WA 99352-1609

Pat Brady

Geochemistry Department, 6118

Sandia National Laboratories

P.O. Box 5800

Albuquerque, NM 87185-0750

Charles R. Bryan

Sandia National Laboratories

4100 National Parks Highway

Carlsbad, NM 88220

Susan Carroll

Lawrence Livermore National Laboratory

MS L-219

Livermore, CA 94550

Jon Chorover

Associate Professor - Environmental

Chemistry

Department of Soil, Water, and

Environmental Science

Shantz 429, Building \#38

University of Arizona

Tucson, AZ 85721-0038

Dave G. Coles

Coles Environmental Consulting

750 South Rosemont Road

West Linn, OR 97068
No. of

Copies

Mark Conrad

Department of Earth and Planetary Sciences

University of California, Berkeley

Berkeley, CA 94720

Dr. James A. Davis

U.S. Geological Survey

MS 465

345 Middlefield Road

Menlo Park, CA 94025

Donald J. DePaolo

Geology \& Geophysics Dept. MC4767

University of California

Berkeley, CA 94720-4767

Dirk A. Dunning

Oregon Office of Energy

625 Marion Street, N.E.

Salem, OR 97301-3742

Mark Ewanic

MSE Technology Applications, Inc.

200 Technology Way

Butte, MT 59701

Markus Flury

Department of Crop and Soil Sciences

Washington State University

Pullman, WA 99164

Amy P. Gamerdinger

2122 E. Hawthorne

Tucson, AZ 85719

Jim Harsh

Department of Crop \& Soil Sciences

Washington State University

Johnson Hall, Room 249

Pullman, WA 99164-6420 
No. of

Copies

Dr. Cliff Johnston

Soil Chemistry and Mineralogy

1150 Lily Hall

Purdue University

West Lafayette, IN 47907-1150

Dr. Daniel I. Kaplan

Westinghouse Savannah River Company

Building 774-43A, Room 215

Aiken, SC 29808

Dr. David Kosson

Vanderbilt University

VU Station B \#351831

2301 Vanderbilt Place

Nashville, TN 37235-1831

Dr. Jim Krumhansl

Sandia National Laboratory

P.O. Box 5800

Albuquerque, NM 87185-0750

Dr. Christine Langston

Westinghouse Savannah River Co.

Building 774-43A

Aiken, SC 29808

Dr. Peter C. Lichtner

Los Alamos National Laboratory

P.O. Box 1663

Los Alamos, NM 87545

Sandra Lilligren

Nez Perce

P.O. Box 365

Lapwai, ID 83540

Kate Maher

The Center for Isotope Geochemistry

301 McCone Hall

University of California, Berkeley

Berkeley, CA 94702-4746
No. of

Copies

Melaine A. Mayes

Environmental Sciences Division

Oak Ridge National Laboratory

P.O. Box 2008

Oak Ridge, TN 37831-6038

Dr. Kathryn L. Nagy

Department of Earth and Environmental

Sciences

University of Illinois at Chicago (MC-186)

845 West Taylor Street

Chicago, IL 60607-7059

Heino Nitsche

Director, Center for Advanced

Environmental and Nuclear Studies

Lawrence Berkeley National Laboratory

1 Cyclotron Road

MS 70A-1150

Berkeley, CA 94720

Phil Reed

U.S. Nuclear Regulatory Commission

Office of Nuclear Regulatory Research

Division of Systems Analysis and

Regulatory Effectiveness

Radiation Protection, Env. Risk and Waste

Management Branch

MS T9-F31

Washington, D.C. 20555-0001

Richard J. Reeder

Department of Geosciences

State University of New York at Stony

Brook

Stony Brook, NY 11794-2100

Al Robinson

68705, E 715 PRNE

Richland, WA 99352 
No. of

Copies

Phil Rogers

13 Mountain Oak

Littleton, CO 80127

Dr. Sherry Samson

Department EES

University of Illinois at Chicago (MC-186)

845 West Taylor Street

Chicago, IL 60607-7059

David Shafer

Desert Research Institute

University of Nevada

P.O. Box 19040

Las Vegas, NV 89132-0040

Dawn A. Shaughnessy

Glen T. Seaborg Center

Lawrence Berkeley National Laboratory

1 Cyclotron Road

MS 70A-1150

Berkeley, CA 94720

Doug Sherwood

Rivers Edge Environmental

1616 Riverside Drive

West Richland, WA 99353

David K. Shuh

Lawrence Berkeley National Laboratory

1 Cyclotron Road

MS 70A-1150

Berkeley, CA 94720

James "Buck” Sisson

Idaho National Engineering and

Environmental Laboratory

P.O. Box 1625, MS 2107

Idaho Falls, ID 83415-2107
No. of

Copies

Carl I. Steefel

Lawrence Livermore National Laboratory

Earth \& Environmental Sciences Directorate MS L-204

P.O. Box 808

Livermore, CA 94551-9900

Dr. Samuel J. Traina, Director

Sierra Nevada Research Institute

University of California, Merced

P.O. Box 2039

Merced, CA 95344

Dan Tyler

Freestone Environmental Services

1933 Jadwin Avenue

Richland, WA 99354

Dr. T. T. Chuck Vandergraaf

Atomic Energy of Canada, Limited

Whiteshell Nuclear Research Establishment

Pinawa, Manitoba ROE 1LO

Canada

Dr. Jiamin Wan

Lawrence Berkeley National Laboratory

1 Cyclotron Road, MS 70-0127A

Berkeley, CA 94720

Mr. Ronald G. Wilhelm

Office of Radiation and Indoor Air

401 M Street, S.W.

Mail Code 6603J

Washington, D.C. 20460

W. Alexander Williams

U.S. Department of Energy

Office of Environmental Restoration

EM-33

19901 Germantown Road

Germantown, MD 20874-1290 
No. of

Copies

ONSITE

4 DOE Office of River Protection

P. E. LaMont

H6-60

R. W. Lober

H6-60

R. A. Quinterro

S. A. Wiegman

8 DOE Richland Operations Office

B. L. Foley

J. P. Hanson

R. D. Hildebrand

K. A. Kapsi

J. G. Morse

K. M. Thompson

DOE Public Reading Room (2)

14 CH2M HILL Hanford Group, Inc.

M. P. Connelly (5)

T. E. Jones

F. J. Anderson

F. M. Mann

J. G. Kristofzski

D. Parker

J. A. Voogd

W. J. McMahon

D. A. Myers

D. M. Nguyen
H6-03

H6-03

H6-03

A6-38

A5-13

A6-38

A5-13

A6-38

A6-38

H2-53

H6-03

H6-03

H6-03

H6-03

H6-03

H6-03

R2-12

No. of

Copies

3 Environmental Protection Agency
N. Ceto
B5-01
D. A. Faulk
B5-01
M. L. Goldstein
B5-01

2 Fluor Federal Services

R. Khaleel

E6-17

R. J. Puigh

E6-17

4 Fluor Hanford, Inc.

T. W. Fogwell

E6-35

B. H. Ford

E6-35

J. G. Hogan

H1-11

M. I. Wood

H8-44

\section{Stoller}

R. G. McCain

B2-62

5 Washington State Department of Ecology
J. A. Caggiano
$\mathrm{H} 0-57$
S. Dahl
$\mathrm{H} 0-57$
J. J. Lyon
$\mathrm{H} 0-57$
E. A. Rochette
$\mathrm{H} 0-57$
J. Yokel
$\mathrm{H} 0-57$

49 Pacific Northwest National Laboratory

3 Duratek Federal Services, Inc., Northwest Operations
B. W. Arey
K8-93
D. H. Bacon
K9-33
S. R. Baum
P7-22
B. N. Bjornstad
K6-81
C. F. Brown
P7-22
R. W. Bryce
E6-35
K. J. Cantrell
K6-81
R. E. Clayton
K6-75 
No. of

Copies
W. J. Deutsch (5)
P. E. Dresel
K. M. Geisler
M. J. Fayer
A. R. Felmy
M. D. Freshley
J. S. Fruchter
N. J. Hess
D. G. Horton
J. P. Icenhower
C. T. Kincaid
K. M. Krupka (3)
I. V. Kutnyakov
G. V. Last
M. J. Lindberg
W. J. Martin
S. V. Mattigod

No. of

Copies

K6-81

K6-96

P7-22

K9-33

K8-96

K9-33

K6-96

P7-50

K6-81

K6-81

E6-35

K6-81

P7-22

K6-81

P7-22

K6-81

K6-81
B. P. McGrail

P. D. Meyer

C. J. Murray

S. M. Narbutovskih

R. D. Orr

E. M. Pierce

N. Qafoku

S. P. Reidel

R. G. Riley

R. J. Serne

H. T. Schaef

W. Um

M. Valenta

B. A. Williams

S. B. Yabusaki

J. M. Zachara

Hanford Technical Library (2)
K6-81

BPO

K6-81

K6-96

K6-81

K3-62

K3-61

K6-81

K2-21

P7-22

K6-81

P7-22

P7-22

K6-81

K9-36

K8-96

P8-55 